\title{
ASSESSORIA ADMINISTRATIVA A PRODUTORES RURAIS NO BRASIL
}

\author{
JOSÉ ROBERTO FERNANDES CANZIANI
}

Tese apresentada à Escola Superior de Agricultura "Luiz de Queiroz", Universidade de São Paulo, para obtenção do título de Doutor em Ciências, Área de Concentração: Economia Aplicada.

P I R A C I C A B A

Estado de São Paulo - Brasil

Junho de 2001 


\title{
ASSESSORIA ADMINISTRATIVA A PRODUTORES RURAIS NO BRASIL
}

\section{JOSÉ ROBERTO FERNANDES CANZIANI}

Engenheiro Agrônomo e Economista

\author{
Orientador: Prof. Dr. FERNANDO CURI PERES
}

Tese apresentada à Escola Superior de Agricultura "Luiz de Queiroz", Universidade de São Paulo, para obtenção do título de Doutor em Ciências, Área de Concentração: Economia Aplicada.

P I R A C I C A B A

Estado de São Paulo - Brasil

Junho de 2001 
Dados Internacionais de Catalogação na Publicação (CIP)

DIVISÃO DE BIBLIOTECA E DOCUMENTAÇÃO - Campus “Luiz de Queiroz"/USP

Canziani, J osé Roberto Fernandes

Assessoria administrativa a produtores rurais no Brasil / José Roberto Fernandes Canziani. - - Piracicaba, 2001.

$224 \mathrm{p}$.

Tese (doutorado) - Escola Superior de Agricultura Luiz de Queiroz, 2001.

Bibliografia.

1. Administração agrícola 2. Assessoria agrícola 3. Empresa agropecuária 4. Produtor rural I. Título

CDD 331.763

"Permitida a cópia total ou parcial deste documento, desde que citada a fonte - O autor" 
Dedico este trabalho aos meus pais, Nei (em memória) e Carmen, a minha esposa Elaine e aos meus filhos José Roberto e Eloísa. 


\section{AGRADECIMENTOS}

Muitas pessoas contribuíram direta e indiretamente para a elaboração deste trabalho. Sou grato a todos.

Ao meu orientador, Prof. Fernando Curi Peres, faço um agradecimento especial pelas orientações que me transmitiu ao longo de todo o desenvolvimento do trabalho. Agradeço-lhe, também, pela sua franqueza em nossas discussões, pela sua cordialidade e pelo seu exemplo de profissionalismo.

Aos amigos Derli Dossa, Vania Guimarães e Elaine Bernardes agradeço pelas idéias que me transmitiram, pelas leituras e críticas ao texto e pelo apoio e motivação, que foram fundamentais para o desenvolvimento do trabalho.

Sou grato, também, aos professores Zilda Mattos, Evaristo Neves, Adriano Azevedo Filho e Ricardo Shirota que participaram nas fases iniciais.

Agradeço aos meus irmãos Nei, Maria Eugênia e Mônica pelo incentivo e carinho a mim dispensados, que foram importantes para que eu atingisse meus objetivos.

Aos colegas de residência Daltro, Robson, Ary, André, Mauro e Humberto agradeço pelo companheirismo e pelos momentos de descontração. 
Agradeço a OCEPAR, FAEP e SENAR-PR pelo apoio na aplicação do questionário da pesquisa, e a todos que o responderam ou contribuíram para a sua divulgação.

Sou grato aos funcionários e professores do DEAS/ESALQ que possibilitaram a realização do curso de doutorado, e aos professores do DERE/UFPR que assumiram meus encargos de trabalho durante o período de meu afastamento. Por fim, agradeço a CAPES pelo apoio financeiro. 


\section{SUMÁRIO}

Página

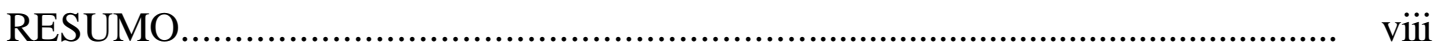

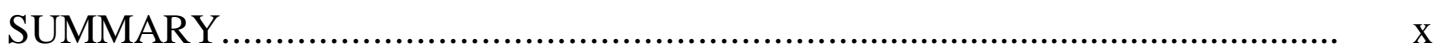

1. INTRODUÇÃO ..........................................................................

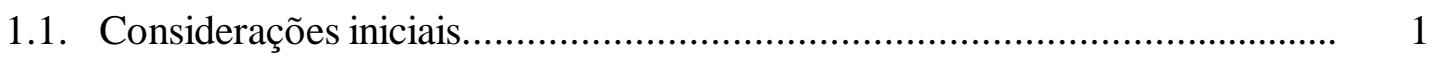

1.2. Definição do problema..................................................................... 4

1.3. Justificativa do estudo........................................................................ 4

1.3.1.Carência de estudos e iniciativas em administração rural......................... 5

1.3.2.O processo administrativo e a necessidade de mudanças......................... 11

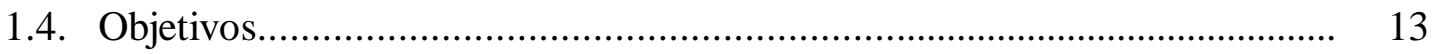

2. REVISÃO DE LITERATURA...................................................... 14

2.1. O processo administrativo e o resultado econômico.................................. 14

2.2. O processo administrativo e os objetivos do produtor.............................. 19

2.2.1. Otimização de objetivos.................................................................... 24

2.3. O processo de coorientação entre produtores e assistência técnica.............. 31

2.4. O processo de aconselhamento gerencial aos produtores......................... 39

3. MODELO TEÓRICO.............................................................................. 44

3.1. Matriz de atividades administrativas............................................ 48

3.2. Hipóteses sobre a relevância das atividades administrativas................... 54 


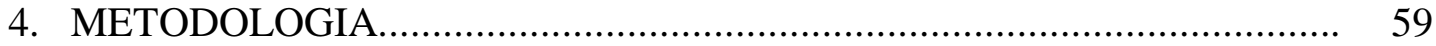

4.1. Dificuldades no processo administrativo.................................................... $\quad 60$

4.1.1.A técnica de grupos focais...................................................................... 60

4.1.2.Definição da amostra............................................................................ 65

4.2. Opiniões e percepções sobre a administração da empresa agropecuária................................................................................. 66

4.2.1.Estruturação do questionário..................................................................... 67

4.2.2.Definição da amostra................................................................................. 71

4.2.3.Análise estatística ............................................................................... $\quad 78$

5. RESULTADOS E DISCUSSÃO......................................................... 80

5.1. Resultados qualitativos: a competência no processo administrativo.......... 80

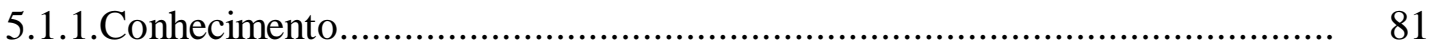

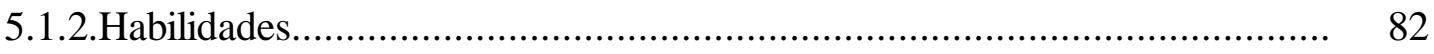

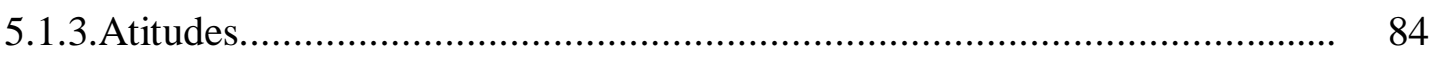

5.2. Resultados quantitativos: diferenças de opiniões e percepções entre produtores rurais e profissionais da assistência técnica.............................. 87

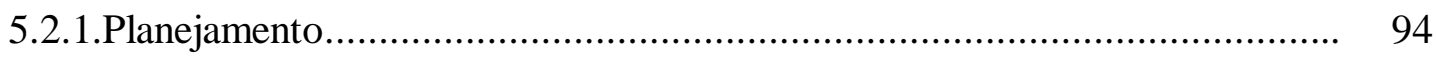

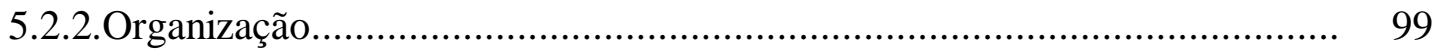

5.2.3.Direção........................................................................................... 106

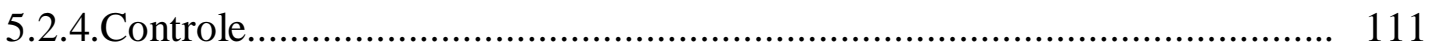

6. RECOMENDAÇÕES PARA A PRÁTICA DA ADMINISTRAÇÃO

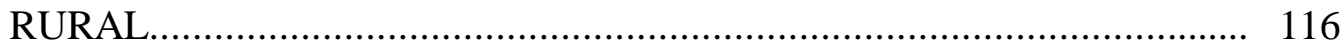

6.1. As empresas agropecuárias referenciais.................................................. 117

6.1.1.Empresa referencial Grãos.................................................................... 124

6.1.2.Empresa referencial Bovino de corte..................................................... 127

6.1.3.Empresa referencial Cana-de-açúcar......................................................... 130

6.1.4.Empresa referencial Café....................................................................... 131

6.1.5.Empresa referencial Frango................................................................... 133 
6.1.6.Empresa referencial Hortifruti............................................................ 135

6.1.7.Empresa referencial Pequena Produção...................................................... 136

6.2. A Importância da gestão por área administrativa...................................... 138

6.3. O planejamento nas empresas agropecuárias referenciais........................... 148

6.3.1. Relevância do planejamento.................................................................... 148

6.3.2.Filosofias de planejamento................................................................... 159

6.3.3.Técnicas de planejamento...................................................................... 163

6.4. A organização nas empresas agropecuárias referenciais............................ 171

6.4.1.Relevância da organização.................................................................... 174

6.5. A direção nas empresas agropecuárias referenciais................................... 176

6.5.1.Relevância da direção............................................................................. 178

6.6. O controle nas empresas agropecuárias referenciais................................. 181

6.6.1.Relevância do controle........................................................................ 184

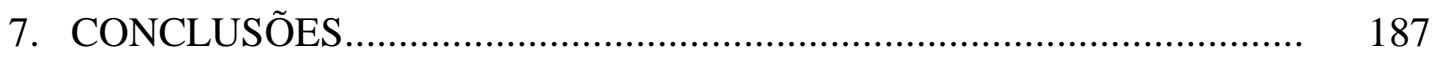

REFERÊNCIAS BIBLIOGRÁFICAS.......................................................... 191

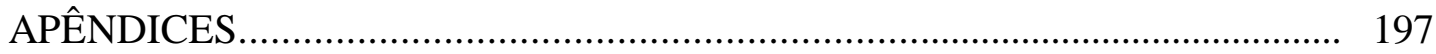




\title{
ASSESSORIA ADMINISTRATIVA A PRODUTORES RURAIS NO BRASIL
}

\author{
Autor: José Roberto Fernandes Canziani \\ Orientador: Prof. Dr. Fernando Curi Peres
}

\section{RESUMO}

Este estudo identificou um conjunto de razões que limita o uso de técnicas de gestão nas empresas agropecuárias. Analisando como os produtores rurais administram os seus negócios, e em acordo com a teoria da administração, estas razões foram discutidas através de uma matriz de atividades administrativas. Essa matriz relaciona as funções de planejamento, organização, direção e controle, exercidas no nível estratégico e operacional da empresa agropecuária, com as áreas administrativas de produção, finanças, comercialização e pessoal. Isso possibilitou uma identificação mais precisa dos fatores limitantes à gestão da empresa agropecuária e suas relações com a competência administrativa, composta pelas variáveis conhecimento, habilidades e atitudes. Os principais motivos que justificam o baixo envolvimento dos profissionais da assistência técnica com a gestão da propriedade rural também foram identificados. A coleta de dados primários envolveu duas fases. Na primeira, a investigação valeu-se da técnica de grupos focais, que permitiu reunir informações qualitativas sobre o assunto, em 8 sessões focais com agricultores, pecuaristas e os técnicos que os assistem. Na segunda fase, o assunto foi abordado de forma quantitativa, através da aplicação de 494 questionários junto ao mesmo público alvo, em vários estados do país. Os dados quantitativos foram 
analisados estatisticamente e os resultados se mostraram altamente significativos $(\mathrm{P}<0,05)$. Em linhas gerais, as principais conclusões do estudo foram: (1) a natureza familiar predominante na empresa agropecuária lhe confere uma forma própria de gestão; (2) há significativas diferenças na opinião e percepção de técnicos e produtores sobre a melhor forma de se gerenciar as empresas agropecuárias; (3) os produtores rurais não alteram, contínua e sistematicamente, seu planejamento estratégico de produção, em função das incertezas de mercado e dos custos associados à alteração do processo produtivo; (4) no planejamento financeiro, os produtores rurais normalmente direcionam seus recursos para serem aplicados em estoques ou ativos fixos; (5) na organização da infraestrutura e do pessoal, há uma tendência dos produtores em superdimensionar a disponibilidade desses fatores de produção, visando uma redução dos riscos operacionais inerentes à produção; (6) na organização das finanças, normalmente há um descompasso entre o detalhamento dos registros e a real capacidade de implementá-los com eficiência na empresa; (7) a estrutura funcional dos recursos humanos é ineficiente e centralizada, com acúmulo de responsabilidades no produtor rural; (8) a direção operacional da produção ocupa o maior tempo de trabalho do produtor, gerando ineficiências na direção das demais áreas administrativas; (9) as principais dificuldades no controle são a coleta de dados a campo, resultado do baixo nível de conhecimento, habilidades e atitudes de seus funcionários; e (10) a formulação de recomendações para o gerenciamento da empresa agropecuária deve considerar as características da empresa e do empresário rural, ao invés de serem estabelecidas a priori sem o conhecimento da situação particular de cada caso. Por fim, considerando a importância relativa das diferentes atividades administrativas em empresas agropecuárias referenciais e os fatores limitantes à gestão nessas empresas, fez-se recomendações para a melhoria do processo de aconselhamento administrativo aos produtores rurais. 


\title{
COUNSELING BRAZILIAN FARMERS ON THEIR MANAGEMENT ACTIVITIES
}

\author{
Author: José Roberto Fernandes Canziani \\ Adviser: Prof. Dr. Fernando Curi Peres
}

\section{SUMMARY}

The study identified some reasons that explain the limited use of scientific management tools by Brazilian farmers. A matrix of management activities was built to classify these reasons. The matrix crosses the management functions of planning, organizing, directing, and controlling, considered both in the strategic and operational levels, with the production, financial, commercial, and human resource administrative areas. This classification allowed a more precise identification of factors that are limiting the use of scientific management tools and their relationship to the farmer's competence as given by their knowledge, abilities and attitudes. The study also identified some of the major reasons that explain why extension agents were not fully involved with counseling farmers on their management activities. Primary data used in the study were collected during two phases. During the first, 8 focus group manned by cash crop farmers, beef cattle farmers, and extension agents and counselors, were used to produce qualitative information. During the second phase, quantitative information were collected via a survey with 494 individual questionnaires applied to the same public covered by phase one. For the statistical tests performed $95 \%$ of significance was required. Some conclusions of the study are: (1) the family farm predominant nature requires an specific form of 
management; (2) farmers differ significantly from extension agents or counselors on farm management subjects; (3) farmers do not alter their strategic production plans in response to price changes or other signals perceived as short or mid term movements due to costs of changes in their production processes; (4) in managing their cash flow, farmers tend to immobilize their resources as fixed assets, therefore dangerously reducing their liquidity ratios; (5) in organizing their human resources structure farms tend to concentrate into their hands amounts of responsibilities larger than they can handle; (6) in organizing their financial flows there is a large gap between the desired level of details and their abilities to collect the data; (7) in organizing farm's production infrastructure and human resource base there is a tendency to overestimate their needs in order to reduce productive or operational risks; (8) directing the productive process requires most of the time of the farmer, therefore reducing the amount of time dedicated to other areas of the administrative process; (9) the major difficulties faced in the function of controlling are linked with problems of collecting data. This is due to low levels of formal education that characterize the farm hired labor; and (10) counseling rules should not be formulated as general rules but the farm and the farmer individual characteristics must be considered in counseling for management purposes. Finally, the relative relevancy of the managerial activities in the "referential farms" were considered, together with their limiting managerial factors, in recommending improvements in the process of managerial counseling to farmers. 


\section{INTRODUÇÃO}

\subsection{Considerações iniciais ${ }^{1}$}

Vários estudos têm mostrado que empresas rurais melhor administradas obtêm melhores resultados econômicos. Isso significa que uma maior adoção das funções administrativas de planejamento, organização, direção e controle, por parte dos produtores rurais, pode contribuir positivamente para melhorar o resultado econômico de suas empresas (Phillips \& Peterson, 1999; Miller et al., 1998; entre outros). No entanto, apesar dessa provável associação positiva entre o uso de técnicas de gerenciamento e o sucesso econômico das empresas rurais, tem-se observado que a maioria dos produtores rurais no Brasil ainda não adota, de maneira formal e eficiente, várias práticas administrativas que poderiam proporcionar maior competitividade aos seus negócios. (Meira, 1996; Dalmazo \& Albertoni, 1991; entre outros).

Tem-se verificado também um baixo envolvimento qualitativo e quantitativo dos profissionais da assistência técnica e extensão rural (engenheiros agrônomos, médicos veterinários, zootecnistas, etc.) em assuntos relacionados ao processo administrativo das empresas rurais. (Olinger, 1998; Lima et al., 1995; Guadagnin, 1995; Geraldo, 1991). As razões para esse baixo uso de técnicas de gestão pelos produtores rurais e do baixo apoio, na área administrativa, que os profissionais da

\footnotetext{
${ }^{1}$ Este item apenas apresenta o assunto do trabalho, visando antecipar ao leitor uma visão geral sobre as discussões que serão apresentadas ao longo do texto.
} 
assistência técnica e extensão rural fornecem aos produtores rurais do país, ainda não são bem compreendidas.

Vários fatores limitantes ao desenvolvimento da administração rural no Brasil poderiam ser enumerados conforme relacionado abaixo, mas sua comprovação efetiva e a identificação da importância relativa de cada um para os produtores dependem de maiores estudos.

a) Dificuldade de compreensão do quadro teórico e metodológico do processo de gestão rural no país, tanto por parte dos produtores como por parte dos profissionais que trabalham com assistência técnica e extensão rural.

b) Certa desconfiança, por parte dos produtores e até dos técnicos, quanto à necessidade e a eficácia de se usar um processo de gestão mais acurado, envolvendo, por exemplo, o planejamento formal para ações de longo prazo ou o controle individualizado do fluxo de caixa das atividades existentes. Essa atitude negativa pode estar relacionada a vários fatores não controláveis que afetam o resultado econômico das empresas rurais e dificulta o seu processo administrativo.

c) Maior custo dos serviços de uma assistência agropecuária mais abrangente (englobando técnicas de gestão) e carência no mercado de profissionais relativamente autônomos, sem vínculo com empresas que mantêm relações comerciais com os produtores rurais, e dispostos a assumir algumas funções de cunho administrativo junto às empresas rurais.

d) Alto custo para se implantar sistemas de registro contábil, principalmente pelo esforço necessário à coleta de dados precisos em nível de campo e, dificuldades para se gerar e interpretar as informações relevantes ao processo decisório nas empresas rurais.

Essa pesquisa pretende estudar melhor as questões acima, procurando, inicialmente, confirmar quantitativa e qualitativamente o baixo uso das técnicas de gestão nas propriedades rurais do país, para em seguida caracterizar as principais razões que levam a essa situação e assim, ao final, poder propor um "roteiro" com formas alternativas de trabalho. Com o "roteiro" pretende-se, de um lado, contribuir para um 
processo de gestão mais eficiente por parte dos produtores rurais e, de outro, facilitar e melhorar a eficiência dos serviços de aconselhamento gerencial que os técnicos precisam transmitir cotidianamente aos produtores.

O desenvolvimento de novos estudos sobre as questões listadas de "a" a "d" torna-se relevante pelas suas prováveis contribuições futuras. Sua melhor compreensão poderia resultar no estabelecimento de novas estratégias de ações administrativas, tanto por parte dos produtores como por parte dos técnicos que atuam no setor agropecuário. Assim, de um lado, teríamos produtores rurais mais bem assistidos em termos gerenciais e, provavelmente, com melhores resultados econômicos e, de outro, profissionais da assistência técnica e extensão rural com maior campo de trabalho e, provavelmente, com maior remuneração. Esse possível redirecionamento de atitudes por parte de produtores e técnicos vem de encontro, inclusive, às rápidas transformações econômicas e tecnológicas que vêm ocorrendo em nível mundial. Elas têm comprometido a sustentabilidade de muitos sistemas de produção e exigido das empresas um constante acompanhamento e adequação de suas estratégicas competitivas, através de um processo de gestão mais ágil e eficiente. Assim, a pesquisa certamente contribuirá para o desenvolvimento dos serviços de assessoria administrativa a produtores rurais que exploram importantes sistemas de produção na agropecuária brasileira. 


\subsection{Definição do problema}

No Brasil, muitos empresários rurais não têm conseguido gerir seus empreendimentos com a agilidade e a eficiência necessárias para mantê-los em situação competitiva no mercado. Mesmo ciente dessas dificuldades e da associação positiva existente entre o uso de técnicas de gerenciamento e o sucesso econômico das empresas rurais, a área de administração, nessas empresas, não tem recebido a devida atenção por parte dos profissionais que trabalham com assistência técnica e extensão rural.

O problema em questão diz respeito ao desconhecimento das principais razões que justifiquem o atual baixo uso de técnicas de gerenciamento nas empresas rurais do país e a conseqüente dificuldade para a atuação dos profissionais que trabalham com assistência técnica e extensão rural, no processo de aconselhamento técnico e gerencial aos produtores.

\subsection{Justificativa do estudo}

A justificativa desse estudo se impõe através de duas vertentes principais. A primeira está relacionada à carência de estudos e iniciativas sobre a área de administração rural no Brasil, mas, sobretudo, a carência de trabalhos relacionados ao tema específico proposto pela pesquisa. Ele envolve uma investigação realizada simultaneamente junto aos produtores rurais comerciais ${ }^{2}$ e aos técnicos da iniciativa privada que os assistem, a fim de identificar quais são as principais razões que explicam a baixa adoção de técnicas de gestão nas empresas agropecuárias.

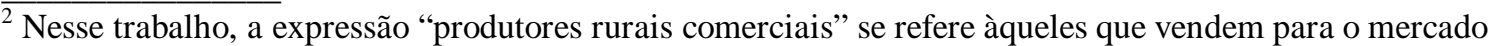
a maior parte de sua produção. Exclui-se da análise, portanto, as propriedades rurais voltadas predominantemente para auto-subsistência. A opção por se fazer esta distinção no trabalho, levou em consideração o pressuposto de que as formas de gestão da propriedade rural são diferentes nos dois casos.
} 
A segunda vertente para demonstrar a relevância dessa pesquisa, parte do pressuposto que uma melhor compreensão das razões que levam a essa baixa adoção de técnicas de gestão nas propriedades rurais do país possa facilitar o desenvolvimento de estratégias de trabalho, tanto para os produtores como para os técnicos. Assim, se estará contribuindo para a geração de atitudes mais favoráveis por parte de ambos na utilização mais efetiva de técnicas de gestão nas empresas rurais do país.

\subsubsection{Carência de estudos e iniciativas em administração rural}

No Brasil vários autores, já há muito tempo, apontam para a necessidade de maiores esforços por parte dos produtores rurais, dos profissionais da assistência técnica e dos pesquisadores no sentido de desenvolver a área de administração rural.

Noronha \& Peres (1991), por exemplo, comentando sobre a situação da administração rural no Brasil destacam que houve um grande apoio das instituições de pesquisa agronômica e do sistema público de extensão no sentido da modernização da produção agrícola, e um certo abandono dessas entidades no desenvolvimento da área de administração rural. Os autores lembram que os primeiros esforços no Brasil para se levar aos agricultores, através da extensão rural, conhecimentos de administração rural, ocorreram na década de 60. Naquela época, argumentam que embora os conhecimentos de administração levados aos produtores se limitassem a métodos de escrituração agrícola, planejamento de atividades via orçamento e análises de custo e de resultado econômico, essas iniciativas pareciam ser um importante aliado do então emergente sistema de extensão rural, pois considerava o "lado econômico" das decisões nas empresas rurais. Essas iniciativas, porém, não tiveram o sucesso esperado, pois àquela época, o panorama agrícola, alicerçado no crédito rural farto e subsidiado e, conseqüentemente, na alta rentabilidade das explorações agropecuárias, permitia que produtores, técnicos e pesquisadores se preocupassem principalmente com o processo de adoção das novas tecnologias de produção. Outro fator que contribuiu para o insucesso 
das iniciativas de trabalho com administração rural foi o erro de se introduzir a contabilidade agrícola como sendo o primeiro passo para a administração da empresa rural, devido às altas taxas de inflação vigentes à época na economia brasileira ${ }^{3}$. Além disso, a grande influência da literatura americana, com destaque àquela época para a área da economia da produção, favoreceu um rápido crescimento dos departamentos de economia rural nas universidades brasileiras, com consequiente maior ênfase e prestígio das disciplinas associadas à economia rural e maior negligência e desprestígio das disciplinas associadas à administração rural. Citam, por exemplo, o reduzido número de livros textos brasileiros nessa área e o baixo número de teses de mestrado e artigos científicos publicados nas revistas do setor rural contemplando a área da administração rural.

O trabalho de Lima et al. (1995) confirma a carência de estudos e iniciativas na área de administração rural no Brasil. Ele destaca a falta de referência teórica e metodológica que instrumentalize os profissionais que trabalham com assistência técnica e extensão rural para a efetiva implantação de ações de apoio administrativo aos produtores rurais. $\mathrm{O}$ estudo ressalta que o processo de aconselhamento gerencial aos produtores é um dos principais pontos de estrangulamento para a ação dos técnicos. Destaca ainda que o desenvolvimento teórico e prático da administração rural no país tem se baseado em duas abordagens principais. A primeira se refere à obra "Administração da Empresa Agrícola" de Hoffmann et al. (1976) e a segunda se refere à obra "Administração da Fazenda" de Souza et al. (1990). Sobre a primeira abordagem, os autores enfatizam que ela é insuficiente para o tratamento das diferentes dimensões da problemática administrativa das organizações rurais, pois

\footnotetext{
${ }^{3}$ Àquela época, realmente a grande parte dos trabalhos de "contabilidade agrícola" não teve êxito e foi abandonada. As principais dificuldades com os trabalhos de contabilidade agrícola estiveram relacionadas, por um lado, às altas taxas de inflação vigentes no país, que distorciam completamente os cálculos e análises feitas a partir de valores nominais e, por outro, à baixa disponibilidade de computadores no meio rural para armazenar e processar os dados anotados pelo produtor, levando esses trabalhos a serem considerados: (a) tediosos (pois exigiam muito esforço e tempo de trabalho em cálculos); (b) morosos (pois dependiam da disponibilidade de computadores "centrais" para proceder ao processamento e correção dos valores nominais utilizando-se de indexadores, e do técnico para proceder
} 
naquela obra a administração rural é tida simplesmente como um ramo da economia rural, que acaba restringindo a prática e os problemas de estudos administrativos a uma análise estritamente econômica, com pouca preocupação sobre a ação administrativa propriamente dita. Sobre a segunda abordagem, Lima et al. (1995) destacam ser ela mais completa, principalmente porque supera a perspectiva demasiadamente "economicista" e setorial da atividade administrativa nas empresas rurais, referenciadas na primeira abordagem. Segundo os autores, a segunda abordagem define a administração rural como um ramo da ciência administrativa, contemplando os diferentes elementos do processo administrativo, todas as áreas e os níveis hierárquicos da empresa e o seu relacionamento com o meio ambiente. Ressaltam, porém, limitações quanto a sua aplicabilidade prática, face às particularidades das organizações rurais e a diferenciação socioeconômica existente entre elas.

A falta de ênfase à administração rural no Brasil foi também apontada em relato de Lopes sobre as diretrizes que deveriam, à época, serem aperfeiçoadas visando à consolidação dos serviços de assistência técnica e extensão rural em âmbito nacional. $\mathrm{O}$ autor cita a necessidade de se dar “... uma ênfase especial à administração rural, atualmente tão abandonada e tão relegada a um plano secundário, como um meio de aumentar a eficácia do negócio agrícola, possibilitando ao produtor rural maximizar os seus objetivos" (Lopes, 1989, p.25).

\section{Dalmazo \& Albertoni (1991) destacam um certo amadorismo nos} trabalhos de gestão rural conduzidos no país. Argumentam, por um lado, que os agricultores sempre executaram a seu modo e de acordo com o seu grau de formação e de informação a administração de suas propriedades. Por outro lado, argumentam que valiosos instrumentos de gestão ainda não foram incorporados aos procedimentos normais dos agricultores e dos técnicos que atuam na atividade agrícola.

à análise das informações) e (c) de baixa aplicação prática (pelas constantes mudanças no cenário macroeconômico e na política agrícola do país). 
Apesar das críticas realizadas por Noronha \& Peres, Lima et al., Lopes e Dalmazo \& Albertoni e dos problemas por eles levantados, a situação atual da administração rural no país parece ainda semelhante, sugerindo uma certa inércia dos estudos e iniciativas nessa área do conhecimento. As razões para esse entrave, vale ressaltar, não foram devidamente tratadas por esses autores e muito pouco foi proposto nesses estudos quanto ao desenvolvimento de formas alternativas para o gerenciamento das empresas rurais brasileiras ${ }^{4} 5$.

A não incorporação de adequados instrumentos de gestão nas propriedades rurais pode estar relacionada a problemas de competência administrativa de várias ordens ${ }^{6}$. Aqui, o termo competência engloba as seguintes variáveis: conhecimento, habilidades e atitudes. A partir dessa divisão das variáveis que compõe a competência administrativa relaciona-se, a seguir, algumas hipóteses que possam explicar o baixo uso de técnicas de gestão nas empresas rurais brasileiras e que deverão merecer maior atenção ao longo desse estudo.

A insuficiência de conhecimento em administração rural seja, conceitual ou instrumental, pode ser evidenciada, por exemplo, através da dificuldade de compreensão e do uso inadequado de muitas técnicas de gerenciamento no meio rural

\footnotetext{
${ }^{4} \mathrm{O}$ surgimento de um maior interesse pela prática da administração da propriedade rural ("Farm Management") ocorreu nos Estados Unidos e Inglaterra, juntamente com o processo de modernização da agricultura daqueles países. Inicialmente, os primeiros estudos estiveram relacionados à identificação da viabilidade econômica das atividades agrícolas e da viabilidade econômica das recomendações técnicas propostas aos agricultores. Na seqüência, houve uma ampliação das preocupações com a área da administração rural, contemplando outras questões como a mercadologia, política agrícola, estrutura das propriedades rurais, integração da agricultura com a indústria, meio ambiente, entre outras. $\mathrm{Na}$ atualidade há, inclusive, uma preocupação com o desenvolvimento de uma teoria da Gestão da Exploração Agropecuária (Broisser, 1990 citado por Lima et al., 1995).

${ }^{5}$ BROISSER, J. Recherces en Gestion: Vers une theorie de la gestion de l'explotation agrícola. In: BROISSER, J. et al. Modélisation Systémique et Systèrne Agrárie: décision e organisation. Paris: INRA, 1990. p.65-91.

${ }^{6}$ Tratando sobre o processo de adoção de tecnologias por parte dos produtores rurais, Burke \& Molina Filho (1979) afirmam que, embora interdependentes entre si, a adoção de novas técnicas de produção depende de três variáveis básicas: a insuficiência de conhecimento, a falta de condições apropriadas e a falta de disposição a mudanças (conhecer, poder e querer). Essa assertiva dos autores, entretanto, se baseia em modelos unilaterais de transferência de tecnologias, como se os produtores rurais fossem um agente passivo no processo de desenvolvimento rural do país, o que não é verdade.
} 
brasileiro por parte dos produtores e da assistência técnica. Essas dificuldades podem estar relacionadas à própria natureza da experiência acumulada e ao tipo de formação profissional, de maior ênfase em tecnologias de produção, que produtores e técnicos receberam no passado.

A insuficiência de determinadas habilidades para o uso das técnicas de gestão nas empresas rurais, por sua vez, pode ser evidenciada por dificuldades técnicas, humanas, entre outras. Isso significa que o produtor pode até conhecer os modelos de gestão propostos para as empresas rurais, mas não tem condições de adotá-los por restrições de várias ordens e que podem estar relacionadas, por exemplo:

a) ao custo elevado para se implantar sistemas formais e eficientes de controle (coleta de dados por escrito) no âmbito interno das propriedades rurais, em função de suas atividades serem dispersas geograficamente e, principalmente, pelo fato de seus trabalhadores geralmente possuírem baixo grau de educação formal.

b) à má organização da estrutura de pessoal nas propriedades rurais, com conseqüiente acúmulo de responsabilidades para o produtor e alguns funcionários;

c) à má organização ou até inexistência de um plano de contas gerencial nas propriedades rurais, com conseqüente dificuldade para a análise econômica individual das diferentes atividades existentes. A "secular" inflação brasileira também dificultou no passado o processo de análise econômica, pois exigia o uso de indexadores para a atualização monetária dos valores nominais do fluxo de caixa das atividades. Ademais, a baixa disponibilidade de computadores no meio rural e as constantes mudanças institucionais no cenário macroeconômico do país, até um passado recente, também dificultavam o processamento dos dados e análise das informações nas propriedades rurais.

A atitude negativa, por parte de produtores e/ou profissionais da assistência técnica, também pode contribuir para o baixo uso das técnicas de gestão nas empresas agropecuárias. $\mathrm{Na}$ área da administração rural, essas atitudes negativas podem ocorrer, por exemplo, pelos seguintes motivos: 
a) presença de um certo ceticismo, por parte dos produtores e até dos técnicos, quanto à necessidade e a eficácia de se usar técnicas de gestão nas empresas rurais. Por um lado, essa atitude negativa pode estar vinculada à relação mais direta, ou de maior relevância, que outras variáveis possuem sobre o resultado econômico da propriedade rural tais como: a aleatoriedade do clima, as constantes mudanças na política econômica, entre outros.

b) maior preocupação histórica dos produtores com a rápida e permanente adoção de novas tecnologias visando a obtenção de vantagem competitiva da empresa relativamente aos demais produtores atuantes no mercado;

c) maior preocupação histórica dos serviços de assistência técnica e extensão rural em proporcionar ganhos de produtividade da terra e do trabalho ao setor agrícola como sua principal estratégia de demonstrar à sociedade seu papel social;

d) baixa tradição dos produtores rurais em divulgar a terceiros informações sobre sua real situação econômica, financeira e patrimonial. Este fato provavelmente está relacionado aos seguintes fatores:

a. à não exigência de escrituração contábil pela legislação tributária rural;

b. ao vínculo formal que muitos profissionais da assistência técnica possuem com empresas que mantém relações comerciais com os produtores rurais;

c. ao vínculo de obrigações que os profissionais da assistência técnica e extensão rural possuem com o Sistema de Crédito Rural, ora como realizadores de projetos (necessários à obtenção de créditos regulamentados), ora como "fiscais" dos agentes financeiros para verificar a correta aplicação dos recursos.

e) baixa tradição dos produtores rurais do país, em contratar serviços regulares de assessoria em outras áreas, que não aquelas relacionadas aos aspectos tecnológicos (que por muito tempo, foram vinculadas de forma compulsória ao sistema de crédito rural);

f) alto custo para se modificar, no curto e médio prazos, a estrutura vigente nas propriedades rurais, gerando uma certa inércia ou repetição de suas estratégias ao longo do tempo; 
g) maior custo dos serviços de uma assistência agropecuária mais abrangente, que incluam, além da parte tecnológica, outras questões contábeis, econômicas e administrativas.

\subsubsection{O processo administrativo e a necessidade de mudanças}

As mudanças no ambiente macroeconômico em que se encontra o setor rural, também vêm sendo apontadas por vários autores como justificativa para a necessidade de se dar maior atenção à área de administração rural. Noronha \& Peres (1991), por exemplo, comentando sobre as perspectivas da administração rural no país, apontam para a necessidade de se modernizar a administração das empresas rurais, ajustando-a à nova realidade do setor rural e às suas perspectivas. Consideram as seguintes tendências para o setor rural: maior integração das empresas rurais com os mercados de fatores e de produtos exigindo maiores conhecimentos em comercialização, "marketing" e finanças; maior competitividade interna e externa com conseqüentes impactos negativos sobre os preços agrícolas e as margens de lucro dos produtores rurais; menor ajuda governamental ao setor com conseqüente crescimento da participação do setor privado na solução de seus próprios problemas; maior pressão social para a preservação dos recursos naturais e sobre a qualidade dos produtos agrícolas; maior demanda do setor rural por sistemas de informação; modernização do mercado de prestação de serviços ao setor rural; maior demanda por treinamentos formais em administração e maior pressão da legislação trabalhista no campo. Sobre esse estudo, pode-se afirmar que a maioria das tendências apontadas estão efetivamente ocorrendo, mantendo-se assim, ainda presente, a necessidade de se modernizar a administração das empresas rurais no país.

Saxowsky \& Duncan (1998) também analisando as mudanças no ambiente macroeconômico, destacam que a maior competição no mercado agrícola e o surgimento de novas tecnologias de produção, de transporte, de informação e de 
comunicação têm aberto novas oportunidades a algumas empresas rurais para adotarem atitudes de cooperação com a indústria. Essa cooperação pode ocorrer através de sistemas de produção verticalizados, alianças estratégicas, diferenciação de produtos e novos arranjos contratuais, em substituição às estratégias de adoção de tecnologias visando reduzir o custo de produção de commodities. Os autores ressaltam, porém, que no mercado de produtos agrícolas relativamente homogêneos, a vantagem competitiva poderá continuar relacionada aos produtores de grande escala e baixo custo.

Em vista das sugestões apresentadas pelos autores acima, pode-se concluir que são relevantes novos estudos que tratem de questões administrativas no meio rural brasileiro, principalmente daqueles que proponham novas metodologias de trabalho para a ação administrativa. Assim, acredita-se que a atual forma tradicional com que se vem trabalhando com a administração rural no país não conseguirá responder às questões a serem enfrentadas no futuro, tendo em vista: a maior exigência de competitividade; a maior facilidade de acesso a informações; a maior variedade de tecnologias alternativas; as mudanças nas tradicionais formas de financiamento do setor rural; as mudanças nas relações trabalhistas; e as outras mudanças no ambiente macroeconômico do agribusiness que vem rapidamente se transformando e gerando novas oportunidades de negócios através de um processo crescente de diferenciação de produtos e segmentação de mercados.

Portanto, a nova realidade do ambiente macroeconômico exigirá dos produtores e dos profissionais ligados à assistência técnica e extensão rural a busca de novos conhecimentos, a geração de novas habilidades e a adoção de novas posturas e posicionamentos sobre os negócios do setor agropecuário. Para os produtores rurais, caberá uma constante adaptação ou reconversão dos seus sistemas de produção e para as instituições e os profissionais que trabalham com assistência técnica e extensão rural caberá uma constante redefinição de suas estratégias e métodos de atuação. 


\subsection{Objetivos}

\section{Geral:}

O presente trabalho tem por objetivo geral descrever como são administrados, atualmente, os negócios dos produtores rurais comerciais e identificar quais são as razões que levam à baixa adoção de técnicas de gestão nessas empresas. Pretende-se também avaliar a opinião e percepção dos produtores e dos profissionais da assistência técnica sobre o atual processo administrativo dessas empresas e, ao final, propor formas alternativas para a administração de empresas agropecuárias.

\section{Específicos:}

Em vista das soluções geralmente empregadas no enfrentamento de problemas semelhantes ao indicado no objetivo geral, e em vista do exposto na sequiência pela revisão de literatura, a presente pesquisa possui os seguintes objetivos específicos:

1-) Descrever como os produtores rurais comerciais têm conduzido seu processo administrativo e de tomada de decisões e quais são suas principais dificuldades no exercício das funções de planejamento, organização, direção e controle.

2-) Comparar o grau de importância atribuído pelos produtores rurais comerciais e pelos profissionais da assistência técnica privada com relação à administração das áreas gerenciais da propriedade (produção, finanças, comercialização e recursos humanos), procurando identificar diferenças de opinião e percepção na comunicação interpessoal entre eles.

3-) Com base na análise e discussão dos resultados alcançados com os dois objetivos anteriores, espera-se poder contribuir para a melhoria do processo de aconselhamento administrativo aos produtores rurais comerciais. 


\title{
2 REVISÃO DE LITERATURA
}

\begin{abstract}
Neste capítulo são apresentados e discutidos alguns trabalhos relacionados ao problema dessa pesquisa, a fim de se verificar algumas lacunas existentes na literatura sobre as razões que levam ao baixo uso de técnicas de gestão nas empresas agropecuárias. Para uma melhor compreensão dos assuntos correlatos ao problema em estudo, a revisão bibliográfica será subdividida em quatro partes abordando, respectivamente: (1) o processo administrativo da empresa rural e o resultado econômico; (2) o processo administrativo da empresa rural e os objetivos dos produtores; (3) o processo de coorientação de conhecimentos e atitudes dos produtores rurais e da assistência técnica; e (4) o processo de aconselhamento gerencial aos produtores.
\end{abstract}

\subsection{O processo administrativo e o resultado econômico}

É um fato bem estabelecido que o desempenho econômico pode diferir consideravelmente entre empresas rurais, mesmo se elas estão sendo operadas sob condições produtivas mais ou menos similares. As diferenças nos resultados econômicos são geralmente atribuídas a diferenças na administração dos produtores rurais. (Boehlje \& Eidman, 1984 citados por Rougoor et. al, 1998, p. 1). Em geral, os aspectos pessoais dos produtores influenciam o processo de tomada de decisões, e esse, por sua vez, os resultados econômicos das propriedades. 
Segundo Phillips \& Peterson (1999) vários estudos empíricos têm sido conduzidos em alguns setores da economia norte-americana para examinar a relação entre planejamento estratégico e lucratividade (uma importante medida de desempenho da firma). Dentre eles, os autores destacam os seguintes trabalhos: (a) o de Rhyne (1986) que, estudando 14 empresas, procurou identificar a existência de associação positiva entre planejamento e performance da firma e verificou que em apenas um caso essa associação não era observada; (b) o de Schwenk \& Shrader (1993), que estudando 26 empresas, concluiu que o planejamento estratégico é associado significativamente com a performance; (c) o de Miller \& Cardinal (1994) que, considerando as variáveis crescimento e lucratividade (como medida de performance), conclui haver associação positiva entre planejamento estratégico e performance da empresa. Phillips \& Peterson (1999) também destacam em seu trabalho os benefícios do processo de planejamento estratégico que englobam benefícios econômicos, organizacionais, psicológicos e de "marketing" para a empresa, além de despertar maior criatividade junto a seus dirigentes. Ao final do estudo, Phillips \& Peterson propõem um modelo teórico de planejamento estratégico para o caso de pequenos produtores rurais.

Miller et al. (1998) afirmam que o processo de planejamento estratégico em propriedades rurais não é, por si só, garantia de sucesso. Os autores ressaltam que o planejamento estratégico ajuda a definir metas mais realistas na empresa, a gerar novas idéias, a desenvolver criatividade para a solução de problemas e a facilitar a análise de informações técnicas e econômicas. $\mathrm{O}$ estudo revê ainda áreas nas quais o administrador rural faz escolhas estratégicas e alguns dos riscos que acompanham essas escolhas. Ilustra o uso de métodos de planejamento de processos como um meio de ligar estratégias e operação e, descreve o uso de "benchmarks" (padrões de desempenho) como um método para monitorar processos e melhorar o desempenho das empresas rurais. Destaca também a importância do processo (esforço contínuo) ao invés do plano, uma vez que planos estratégicos de sucesso raramente são criados através de um único esforço de planejamento. 
As abordagens de Phillips \& Peterson (1999) e Miller et al. (1998) sugerem a possibilidade de existir uma associação positiva entre a administração eficaz e o resultado econômico das empresas, pelo menos quanto à função de planejamento estratégico que foi a variável considerada. Essas abordagens, porém, não analisam os benefícios econômicos de outras funções ${ }^{7}$ do processo administrativo como o controle, a organização e a direção dos empreendimentos rurais.

O estudo de Westhuizen \& Viljoen (1999) procurou distinguir as práticas administrativas utilizadas por 168 produtores rurais da África do Sul. Os produtores foram classificados em três grupos (terços superior, inferior e mediano) de acordo com o seu desempenho administrativo, segundo um índice de performance (IP) definido em estudo anterior (Burger, 1967) ${ }^{8}$. As principais diferenças nas habilidades administrativas dos "bons" (terço superior) e "maus" (terço inferior) administradores foram observadas, principalmente, na área de finanças (habilidade do grupo para manter registros, analisar dados financeiros e operar computadores). $\mathrm{O}$ estudo procurou também ressaltar, embora de forma um pouco confusa, algumas diferenças existentes entre os grupos, em termos de adoção de algumas práticas (ou funções) administrativas de planejamento, implementação e controle 9 . Quanto a função de planejamento, os resultados do estudo indicaram que os "melhores" produtores usavam mais algumas práticas de planejamento financeiro (orçamentação de atividades e de investimentos) e de planejamento da

\footnotetext{
${ }^{7}$ No presente estudo será utilizada a seguinte nomenclatura para a caracterização: (1) das funções que compõem o processo administrativo (planejamento, organização, direção e controle); (2) dos níveis empresariais de decisão (estratégico e operacional); (3) das áreas administrativas existentes na propriedade rural (produção, finanças, comercialização e pessoal) e (4) dos recursos disponíveis nas propriedades rurais (físicos, financeiros, mercadológicos e humanos). As razões consideradas na escolha dessa nomenclatura serão discutidas adiante no capítulo 3 (Modelo Teórico).

${ }^{8}$ Burger, P.J. (1967). Agricultural progressiveness: A South African concept. D. Agric. (Inst. Agrar.) thesis. University of Pretoria. South África.

${ }^{9}$ Segundo Rougoor et al (1998) um administrador não divide, na prática, o seu tempo em planejamento, implementação e controle. Isso significa que esses conceitos devem ser tornados mais explícitos, através de ações mais formalizadas que possam ser distinguidas e medidas. O autor destaca também que os estudos longitudinais (realizado ao longo de vários anos) são os que possibilitam uma melhor compreensão sobre a capacidade administrativa dos produtores e a eficácia de seu processo de tomada de decisão, pois podem acompanhar no tempo as fases de planejamento, de implementação e de controle. Segundo o autor, a capacidade administrativa é medida pelas características e habilidades pessoais dos produtores para lidar, no momento e na forma correta, com os problemas e oportunidades.
} 
produção (uso mais racional de insumos de acordo com a produtividade esperada das explorações, melhor distribuição espacial das explorações na propriedade, uso de fertilizantes de acordo com o mapa de solos, uso e manutenção mais racional de máquinas, previsões sobre a capacidade de suporte das pastagens, previsões sobre a disponibilidade e uso da mão de obra, entre outros). Na função implementação, os "melhores" produtores eram mais eficientes no manejo sanitário, nutricional e reprodutivo dos rebanhos, no gerenciamento da mão-de-obra, entre outros. Na função controle, os resultados empíricos do estudo mostraram que os "melhores" produtores conheciam melhor seus resultados por atividade e faziam maior uso da informática e da contabilidade. Esse estudo, entretanto, apesar de corroborar indiretamente a hipótese da associação positiva entre o resultado econômico e a adoção de algumas práticas administrativas é confuso na apresentação e discussão dos resultados, pois não diferencia questões administrativas de ordem estratégica e operacional.

Segundo Wylie (1999), os melhores administradores rurais, a despeito das adversidades econômicas, mantêm sua lucratividade ajustando continuamente o seu negócio. Segundo o autor, observando a economia rural australiana, esses ajustes promovidos pela administração podem ocorrer através de esforços para adequar: (1) o “mix" de produção (reduzir riscos através de rotação de culturas e diversificação); (2) a qualidade do produto; (3) a estratégia de comercialização; (4) a tecnologia utilizada (maximizar produtividade e minimizar custos) e (5) a agilidade operacional (planejar atividades críticas). Quanto ao estudo de Wylie (1999), vale ressaltar sua limitação por apenas citar algumas possíveis práticas administrativas que poderiam estar associadas a um melhor desempenho econômico, sem contudo testá-las empiricamente.

Vale (1995), através de um estudo de caso e valendo-se de um modelo de otimização, procurou medir o valor da informação através de seu efeito no desempenho de uma propriedade rural produtora de leite e integrada ao Programa de Pecuária Leiteira da Região de Viçosa (PDPL-RV). O estudo concluiu que o uso da informação tem efeito incremental positivo no resultado da empresa. Ressalva, porém, que as informações 
geradas pelo PDPL-RV foram preponderantemente usadas no nível operacional da empresa (tecnologia) e não houve benefícios quanto ao planejamento da empresa no nível estratégico, pois não foram utilizadas informações econômicas, ambientais e de mercado. $\mathrm{O}$ estudo conclui, ainda, mesmo reconhecendo a dificuldade em se determinar o valor da informação e o seu desempenho na empresa, que novas pesquisas devem ser desenvolvidas visando um melhor conhecimento do tipo de informação desejada pelo tomador de decisão e a forma como é utilizada no processo de tomada de decisão.

No Brasil poucos estudos fazem uma associação entre o processo administrativo e o resultado econômico das empresas rurais. O trabalho de Meira (1996) é um deles e procurou verificar a ocorrência de associação positiva entre a obtenção de sucesso econômico na atividade agrícola e o perfil estrategista-empreendedor de produtores rurais. $\mathrm{O}$ estudo considerou a situação de 11 empresários rurais localizados no Perímetro Irrigado Senador Nilo Coelho, em Petrolina (PE) e concluiu que existia essa associação positiva na área em estudo, pois os produtores mais bem sucedidos possuíam características pessoais que mais se aproximavam do perfil estrategistaempreendedor. Esse perfil foi definido a partir das seguintes características dos produtores: maior visão holística; maior criatividade e espírito inovador; maior atitude positiva ante as incertezas e riscos; maior capacidade de estabelecer prioridades; maior postura racional sem abrir mão da intuição e maior habilidade para definir a missão, os objetivos e as metas do empreendimento, assim como os respectivos recursos necessários de que dispõem para atingi-los. Para a definição quantitativa sobre o perfil estrategista-empreendedor construiu-se no estudo uma escala de atitudes (submetidas a testes de validade e fidedignidade), "tipo-Likert", a fim de pontuar e classificar os produtores num contínuo, segundo sua maior ou menor propensão a pensar e agir de forma empreendedora e estratégica. Para a mensuração do nível de sucesso econômico, foram utilizados os critérios da taxa de retorno sobre o investimento e o valor da relação benefício/custo, tendo em vista a lógica empresarial adotada pelos produtores em estudo. 
A pesquisa conduzida por Meira (1996), entretanto, também concentra sua atenção na função de planejamento estratégico e em parte na função de direção, relegando a um segundo plano as funções de organização e controle dos empreendimentos em estudo. A pesquisa também se limita a identificar a associação positiva entre o sucesso econômico e o perfil empreendedor dos produtores rurais, remetendo aos órgãos de apoio à classe produtora, a tarefa de capacitar os agricultores a "pensar estrategicamente".

\subsection{O processo administrativo e os objetivos dos produtores}

A administração eficiente de uma empresa rural pode ser entendida como a forma mais racional de se utilizar os recursos físicos, financeiros, humanos e mercadológicos da propriedade a fim de se obter resultados compensadores e contínuos, conforme os objetivos do produtor ${ }^{10}$. Dada a diversidade das organizações rurais e a sua condição socioeconômica, os objetivos dos produtores podem ser os mais variados possíveis e inclusive se alterar ao longo do tempo. Isso dificulta uma sistematização ou generalização do processo administrativo para diferentes produtores rurais, exigindo esforços no sentido de tipificação dos produtores para minimizar esse problema. Assim, as funções de planejamento, organização, direção e controle, que em conjunto formam o processo administrativo devem ser analisadas com o devido cuidado, conferindo à administração rural características mistas de "ciência", "técnica" e "arte"11.

\footnotetext{
${ }^{10}$ Segundo Rougoor et al (1998) a administração rural se preocupa com os recursos, as decisões e os resultados e pode ser entendida como um processo "de usar o que você tem para obter o que você quer".

${ }^{11}$ Chiavenato (1993, p. 9-12) reconhece que na literatura sobre administração há muita polêmica, entre os autores, sobre a categorização da administração como ciência, técnica ou arte. O autor, no entanto, defende a idéia de que a administração tem características mistas de ciência e técnica, pois como ciência, a administração gera teorias e hipóteses que permitem uma abordagem prescritiva e normativa intimamente vinculada à técnica de administração, que trata de conduzir as organizações e empresas aos objetivos visados. Segundo o autor, ciência e técnica de administração atuam de forma complementar e interativa, pois o campo explicativo da ciência alimenta a técnica e, dos progressos da aplicação da técnica surge a realimentação para o campo da avaliação e redefinição das explicações científicas.
} 
Sob o ponto de vista econômico, uma melhor administração das empresas rurais pode auxiliar na geração e/ou manutenção de sua competitividade, através de práticas de gestão que tenham por objetivo, em conjunto ou individualmente: a ampliação das margens de lucro; a redução dos custos unitários de produção; a redução dos riscos de produção e de mercado, entre outros. Vale ressaltar, porém, que existem várias formas para se atingir os objetivos desejados. A estratégia de ação para se atingir os objetivos pode envolver simultaneamente vários procedimentos, como por exemplo, uma melhor combinação de atividades, a utilização de recursos ociosos, a redução de despesas, o aumento de produtividade, a racionalização de processos gerenciais e operacionais; a terceirização de tarefas, a busca de novos arranjos contratuais; a melhor disposição dos campos, benfeitorias e explorações, entre outros.

Mais objetivamente, Langemeier \& Delano (1999) entendem que a eficiência global de uma propriedade rural é composta por eficiência de escala, eficiência alocativa e eficiência técnica ${ }^{12}$. Estudando o desempenho de 195 propriedades rurais do Estado do Kansas nos Estados Unidos, os autores procuraram analisar a existência de relações entre a eficiência global e algumas características das propriedades e dos produtores rurais. Suas conclusões indicaram que a eficiência global estava significativamente relacionada, de maneira direta, à idade do produtor, ao tamanho da empresa rural e aos tipos de atividades existentes nas propriedades ${ }^{13}$. Constataram também que $26,7 \%$ das propriedades permaneceram entre as $33 \%$ melhores em termos de eficiência global durante mais da metade de um período de 24 anos (1973 a 1996).

\footnotetext{
${ }^{12}$ Eficiência técnica é a habilidade para evitar gastos ou perdas a fim de se atingir a máxima produção com o menor uso possível de recursos. A eficiência alocativa é a habilidade para combinar insumos e produtos, em proporções ótimas, a luz dos preços de mercado. A eficiência de escala é a habilidade ou condição de se produzir no melhor tamanho possível, diluindo os custos fixos do empreendimento.

${ }^{13}$ Rougoor et al (1998) chamam a atenção para a dificuldade de se generalizar associações dessa natureza e para comparar os resultados de diferentes estudos, que associam características dos produtores e os resultados das propriedades, em função da diversidade das metodologias empregadas.
} 
Além de questões vinculadas à maior eficiência dos negócios rurais, o processo administrativo deve contemplar também outros objetivos dos produtores rurais, tais como: a melhoria do bem estar e da renda líquida familiar; o aumento do valor real do patrimônio (riqueza), a melhoria de imagem do produtor perante a sociedade, a tranqüilidade quanto à sucessão patrimonial, entre outras questões de ordem pessoal ou social. Vários autores apontam nessa direção. Olinger (1984), por exemplo, relaciona vários problemas administrativos, metodológicos e tecnológicos sobre os serviços públicos de extensão rural no Brasil e propõe algumas ações para melhorar a eficácia desses serviços. Em seus argumentos sobre os problemas metodológicos dos serviços públicos de extensão rural no Brasil destaca seu pouco alcance e eficácia junto aos agricultores, pois esses serviços têm atendido apenas $35 \%$ de seu público alvo e, desses, menos de $10 \%$ tem altos índices de produtividade agrícola, com aumento correspondente da renda real líquida. $O$ autor destaca ainda que a receita contida nos pacotes tecnológicos trouxe problemas metodológicos para a extensão, uma vez que pressupunha uma uniformidade inexistente no meio rural, quanto à sua adequação às condições físicas do meio, além de não considerar a situação econômica e cultural dos agricultores. Sobre os problemas tecnológicos destaca, entre outras coisas, a má formação profissional dos técnicos de ciências agrárias, notadamente no que concerne aos aspectos práticos, em vários assuntos de alta relevância para o êxito da ação extensionista, dentre eles a administração rural. Sobre essas questões pontuais, que obviamente fazem parte de uma análise mais abrangente sobre a extensão rural no Brasil, o autor sugere que as escolhas das técnicas a serem difundidas devem levar em consideração, além da economicidade das mesmas, as características da propriedade, suas possibilidades financeiras, e o nível cultural dos agricultores.

Primdahl (1999) também diferencia a forma administrativa de produtores residentes e não residentes nas propriedades rurais e daqueles que trabalham em tempo integral ("full-time") e tempo parcial ("part-time"). O estudo de Primdahl foi feito junto a 700 produtores rurais da Dinamarca e conclui sobre a necessidade de diferenciação no estabelecimento de políticas de apoio para os diversos tipos de produtores. No Brasil, 
essa diferenciação também tem sido algumas vezes considerada, sobretudo em programas governamentais de apoio à agricultura familiar ${ }^{14}$.

O trabalho de Jesus (1993) descreve a trajetória de decisões administrativas de dois produtores rurais da região Sul de Minas Gerais, através de análise interpretativa de suas histórias de vida. O primeiro caso descrito refere-se a uma unidade de produção camponesa, com nítida estratégia de sobrevivência ao longo do tempo e, o segundo, a uma unidade de produção capitalista, onde a estratégia de acumulação predominou ao longo do período em estudo. O estudo não permite generalizações, mas ajuda a esclarecer que muitas ações e atitudes dos produtores rurais, mesmo que inconscientes, estiveram relacionadas ao seu ciclo de vida. Mostra também que o ambiente afeta de forma bastante diferente as propriedades rurais em função de sua heterogeneidade.

Já Olinger (1998), afirma que a extensão rural pública não deve objetivar apenas a manutenção de uma agricultura familiar de subsistência ou sobrevivência, mas sim uma agricultura sustentável que propicie à família dos agricultores um progresso social e econômico equivalente ao desfrutado pela classe média urbana. Afirma, porém, que a extensão rural não opera milagres e, nesse sentido, cabem aos governos ações políticas que assegurem às populações uma vida razoável no meio rural. Noronha \& Peres (1991), por sua vez, reconhecem que as características pessoais dos empresários rurais têm influência sobre os objetivos da empresa e sobre a condução de seus negócios. No entanto, destacam que os empresários rurais devem buscar a eficiência técnica e econômica como condição necessária, em uma economia de mercado, para poderem cumprir seus compromissos de gerar riquezas.

\footnotetext{
${ }^{14}$ A condição de produtor residente tem sido considerada no Brasil em alguns programas governamentais de apoio à agricultura familiar como requisito (ou condição necessária), por exemplo, para se ter acesso a linhas de crédito subsidiadas. Já com relação à distinção entre produtores "full-time" e "part-time" a política de crédito rural no Brasil trata o assunto de forma indireta, através de restrições para o acesso a créditos regulamentados. Uma restrição, por exemplo, é aquela que exige do mutuário a comprovação de que uma percentagem mínima de sua renda bruta anual tenha origem nas atividades agropecuárias.
} 
Dalmazo \& Albertoni (1991) destacam ainda que o trabalho dos técnicos em que predomina a visão "tecnicista" da propriedade não tem ajudado os produtores nos seus problemas de alocação de recursos, definição de objetivos da família/propriedade e nas tomadas de decisão. Além disso, citando pesquisa de campo realizada por Dalmazo et al. (1988) junto a produtores e extensionistas da região oeste catarinense, observa que apenas $27 \%$ dos extensionistas vêem os produtores de forma mais realista, em acordo com as expectativas demonstradas por eles próprios. Nesse estudo, a principal diferença identificada entre os agentes é que, por um lado, enquanto a maioria dos extensionistas prefere recomendar sistemas de produção que visem à maximização da renda líquida das propriedades, de outro, a maioria dos agricultores, por possuírem grande aversão ao risco, preferem combinar suas atividades e definir seus sistemas de produção de modo a minimizar os riscos de produção e de mercado.

As formas de gerenciamento de empresas rurais assumem, portanto, características variadas no tempo e no espaço, sendo geralmente difícil seu processo de generalização. Neste contexto, os serviços de assessoria econômica e administrativa aos produtores rurais devem ser diferenciados conforme as características individuais de cada produtor e dos fatores que interferem em seu processo de decisão ${ }^{15}$, tais como: a idade do produtor (ciclo de vida), seu nível cultural, suas metas e expectativas pessoais, sua propensão ao risco, além de vários outros interesses familiares que estão relacionados ao dispêndio dos recursos da propriedade. A identificação dos objetivos do produtor e de suas características pessoais são, portanto, condições necessárias para

\footnotetext{
${ }^{15} \mathrm{O}$ trabalho de Woodburn (1994), por exemplo, analisa algumas questões consideradas pelos produtores rurais em seu processo de tomada de decisão para a aquisição de computadores. $\mathrm{O}$ trabalho foi realizado junto a uma amostra de 95 produtores comerciais na África do Sul e identificou que os principais argumentos utilizados pelos produtores para o não uso de computadores foram, por ordem de importância: alto custo dos sistemas (35\%); maior exposição de dados confidenciais após a informatização (30\%) e falta de tempo dos produtores para a adoção dos sistemas (23\%). O estudo identificou também que o uso dos computadores tinha abrangência restrita, estando seu uso concentrado no acompanhamento de controles financeiros e de estoques. Por meio de análise estatística, o estudo também concluiu que o maior uso de computadores estava positivamente relacionado a algumas variáveis, tais como: nível educacional dos produtores, tamanho do negócio, maior habilidade com a área de administração financeira, e produtores com atividades fora do meio rural.
} 
qualquer inferência sobre a qualidade dos processos administrativos das propriedades rurais.

\subsubsection{Otimização de objetivos}

A teoria econômica normalmente trata de forma separada ou independente o processo de tomada de decisão de consumo e de produção, via modelos de maximização da utilidade do consumidor e de maximização do lucro da firma. Entretanto, Scitovsky (1951), já há quase meio século, chama a atenção para o fato de que a otimização conjunta de consumo e produção (ou, respectivamente, utilidade e renda líquida) pode ser inconsistente nos casos onde o agente tomador da decisão ocupa ao mesmo tempo a posição de produtor e consumidor. Segundo o autor a inconsistência poderia ocorrer quando a renda líquida do produtor tivesse origem no lucro da firma e ele desejasse simultaneamente maximizar o lucro da firma e a sua utilidade. As figuras 1 e 2 ilustram o referido modelo, onde no eixo horizontal é expresso o tempo de trabalho ou lazer em horas por dia e no eixo vertical o valor monetário das receitas e despesas.

A figura 1 mostra a receita e despesa de um produtor (firma) à medida que o tempo de trabalho e lazer variam. Se o produtor não trabalha, ou seja, ocupa 24 horas por dia de seu tempo com lazer (segmento "ow”) a receita e despesa do produtor é zero. A medida que ele ocupa parte de seu tempo com trabalho (digamos "os" de lazer e "sw" de trabalho) as receitas, despesas e lucro (ou receita líquida) passam a ser

positivas. Nesse modelo a receita líquida é máxima quando o produtor trabalha "tw" horas por dia e tem "ot" horas por dia de lazer, pois a partir desse ponto mais trabalho (por exemplo "xw" de trabalho) reduziria a receita líquida.

Na figura 2 a curva "whx" mostra que a receita líquida cresce inicialmente a taxas decrescentes (segmento "wh") e depois diminui (segmento "hx"). Dessa forma, para maximizar o lucro (“th" unidades monetárias), o produtor deveria 
trabalhar "tw" horas por dia e ter "ot" horas por dia de lazer. As curvas I e II da figura 2, por sua vez, representam curvas de indiferença do produtor entre o tempo de trabalho (ou lazer) e a renda líquida. Supondo que o nível de satisfação ou utilidade do produtor é crescente com relação a aumentos na renda líquida e/ou no lazer, tem-se que a curva II representa um nível de utilidade maior, para combinações de trabalho e renda, que o obtido na curva I. Isso é facilmente observado na figura 2, pois trabalhando "sw" horas por dia o produtor teria um nível de renda de apenas "sv" unidades monetárias com a curva de indiferença I e “sp” unidades monetárias com a curva de indiferença II.

Na figura 2 a curva denominada "receita líquida" representa a restrição orçamentária do produtor. Assim, para maximizar sua utilidade sujeito a restrição orçamentária, o produtor optaria por trabalhar "sw" horas por dia e ter "os" horas de lazer por dia. Esse nível de alocação ótima de trabalho e lazer que maximiza a utilidade do produtor difere ${ }^{16}$, no entanto, da alocação ótima dessas variáveis que maximiza o lucro (ou receita líquida) da firma.

\footnotetext{
16 À única possibilidade de se maximizar simultaneamente a utilidade do produtor e o lucro da firma ocorre quando as curvas de indiferença entre renda e lazer são paralelas ao eixo horizontal, para o exemplo mostrado na figura 02 . No mundo real isso pode ocorrer, por exemplo, nas grandes corporações onde o produtor (ou gerente contratado) age apenas como um "maximizador" do lucro da firma. Nesse caso, seu salário (ou renda) representa o custo de oportunidade de seu trabalho para a empresa, que também pode facilmente substituí-lo caso não persiga o objetivo de maximizar o lucro da firma.
} 


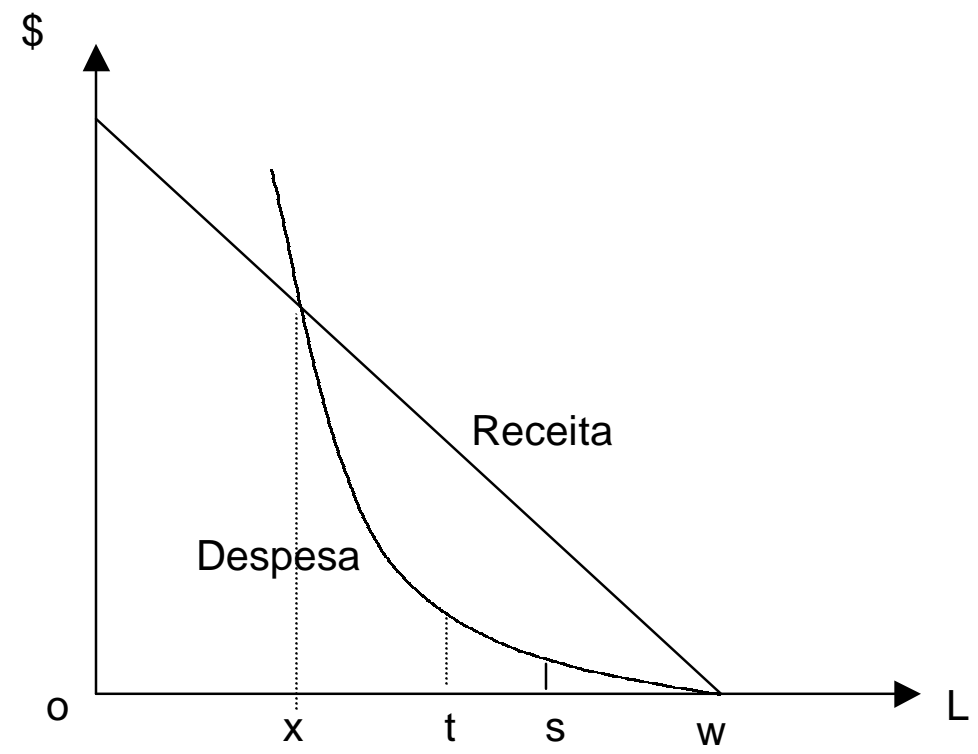

Figura 01 - Receita e despesa do produtor segundo diferentes níveis de lazer.

Fonte: Adaptado de Scitovsky, 1951, p. 143.

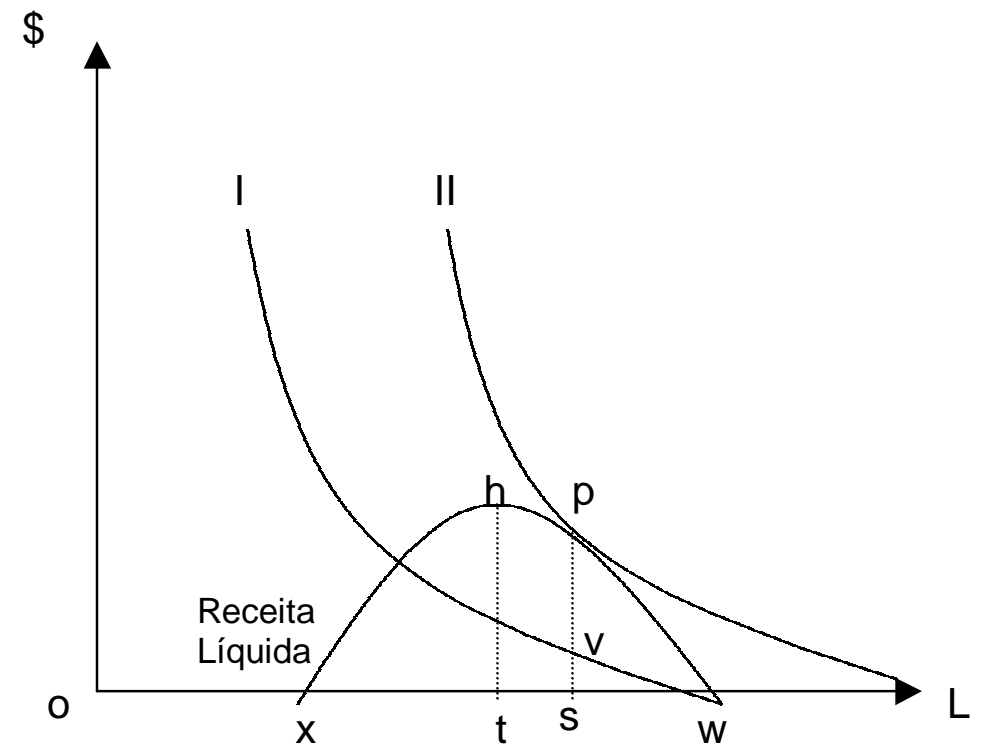

Figura 02 - Divergência entre a maximização do lucro e da utilidade.

Fonte: Adaptado de Scitovsky, 1951, p. 143. 
A despeito desse modelo, sabe-se que no mundo real a maioria dos produtores (especialmente os produtores rurais) desempenha um papel duplo na economia, tanto na produção quanto no consumo de bens e serviços. A maioria dos produtores rurais pode ocupar simultaneamente, enquanto tomadores de decisões, a posição de produtores maximizadores de lucro e de consumidores maximizadores de utilidade. Isso reforça a hipótese de que os modelos econômicos, que consideram que o produtor rural possui apenas um objetivo (por exemplo, maximizar o lucro), têm pouco poder explicativo sobre a maioria das ações econômicas e administrativas das organizações rurais, conforme já discutido no item anterior.

Dentre os modelos que procuram otimizar o processo de tomada de decisão na agricultura, reconhecendo a multiplicidade de objetivos, preferências ou metas dos produtores rurais destacam-se os modelos de programação multi-objetivos ("multi-objective programming models") e os modelos de programação de metas ("goal programming models”). Esses dois modelos de planejamento compõem um tipo de análise denominada programação multicritério ("multiple criteria decision making")" Segundo Sumpsi et al. (1997), na abordagem multicritério a principal dificuldade é a escolha ou definição da forma na qual os objetivos relevantes são considerados no processo de modelagem. Nessa definição, dois aspectos são fundamentais: o estabelecimento da ordem de preferência dos objetivos dos produtores e a determinação da importância ou peso relativo de cada um dos objetivos relevantes ${ }^{18}$.

\footnotetext{
${ }^{17} \mathrm{O}$ termo "critério" se refere à noção geral da combinação de atributos, objetivos e metas. Ambrósio (1997, p.88-89) define: (1) Atributos são valores que o tomador de decisão associa à realidade objetiva. Um atributo é representado por uma função matemática das variáveis de decisão; (2) Objetivos representam a direção para a melhoria de um ou mais atributos. Quando a direção da melhoria implica em "mais é melhor" então o objetivo é maximizado. E, alternativamente, se implicar que "menos é melhor" então o objetivo é minimizado; (3) Níveis de aspiração ou alvos são níveis aceitáveis pelo tomador de decisão a serem alcançados na busca dos vários atributos considerados; (4) Meta é a combinação de um atributo com um nível de aspiração.

${ }^{18}$ O trabalho de Ambrósio (1997, p. 87-131) apresenta e discute as vantagens e desvantagens de diferentes métodos da Programação por Metas e da Programação Multi-objetivo, assim como, as principais técnicas algorítmicas usadas na solução desses problemas. Para a visualização de algumas aplicações empíricas sobre o uso da Programação Multicritério, Ambrósio (1997, p.90) recomenda a edição especial da Agricultural Systems, 41 (3), 1993.
} 
Uma outra corrente de trabalhos empíricos que contempla discussões sobre os objetivos dos produtores rurais se vale de um corpo teórico denominado a teoria da família rural ("The theory of household farm"). No desenvolvimento desses trabalhos, liderados por pesquisadores ${ }^{19}$ do Banco Mundial e das Universidades de Michigan e Yale nos Estados Unidos, são utilizados modelos teóricos ("Agricultural Household Models") que combinam o uso de técnicas de otimização e de econometria. Em sua formulação os modelos consideram, simultaneamente, a necessidade dos produtores rurais em maximizar a sua utilidade pessoal ou familiar e o lucro da firma, com a oferta de trabalho sendo uma variável endógena no modelo. Geralmente o sistema de equações é formulado para se maximizar a utilidade (função objetivo) sujeito a restrições de renda, tempo de trabalho e produção. Em uma forma simplificada esses modelos normalmente são apresentados da seguinte maneira:

$$
\text { Maximizar } \mathrm{U}=\mathrm{U}\left(\mathrm{X}_{\mathrm{a}}, \mathrm{X}_{\mathrm{m}}, \mathrm{X}_{\mathrm{l}}\right)
$$

Onde as "commodities": $\mathrm{X}_{\mathrm{a}}$ são os bens agrícolas produzidos e consumidos na fazenda; $\mathrm{X}_{\mathrm{m}}$ são as mercadorias compradas no mercado e $\mathrm{X}_{1}$ é o lazer.

Sujeito as seguintes restrições:

(a) orçamentária:

$\mathrm{p}_{\mathrm{m}} \mathrm{X}_{\mathrm{m}}=\mathrm{p}_{\mathrm{a}}\left(\mathrm{Q}-\mathrm{X}_{\mathrm{a}}\right)-\mathrm{w}(\mathrm{L}-\mathrm{F})$

onde

$\mathrm{p}_{\mathrm{m}}=$ preço dos bens adquiridos no mercado

$\mathrm{X}_{\mathrm{m}}=$ consumo familiar de mercadorias compradas no mercado

$\mathrm{p}_{\mathrm{a}}=$ preço dos bens agrícolas

$\mathrm{Q}=$ produção dos bens agrícolas

$\mathrm{X}_{\mathrm{a}}=$ consumo familiar dos bens agrícolas

$\left(\mathrm{Q}-\mathrm{X}_{\mathrm{a}}\right)=$ oferta líquida de bens agrícolas no mercado

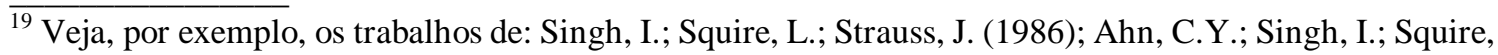
L. (1980); e Barnum, H.N. \& Squire, L. (1979). 
$\mathrm{w}$ = salário de mercado

$\mathrm{L}=$ trabalho total

$\mathrm{F}=$ trabalho familiar

Se $(\mathrm{L}-\mathrm{F})>0$, o produtor rural compra trabalho no mercado

Se $(\mathrm{L}-\mathrm{F})<0$, o produtor rural vende trabalho ao mercado

(b) tempo total de trabalho familiar (T)

$\mathrm{X}_{1}+\mathrm{F}=\mathrm{T}$

(c) função de produção:

$\mathrm{Q}=\mathrm{Q}(\mathrm{L}, \mathrm{A})$

sendo "A" a quantidade fixa de terra

As aplicações empíricas desse modelo têm se direcionado para o planejamento de políticas voltadas ao setor rural, com o intuito de se verificar o impacto de mudanças no cenário macroeconômico sobre os setores rural e não rural. Por exemplo, utilizando-se desse modelo Ahn, C.Y.; Singh, I.; Squire, L. (1980) concluíram, entre outras coisas, que um possível aumento no preço do arroz na Coréia poderia provocar: (a) um aumento na renda rural e portanto um aumento no consumo rural de arroz; (b) uma redução na renda urbana com conseqüente redução no consumo urbano de arroz; (c) um aumento da demanda e da oferta de trabalho no meio rural e (d) uma redução da demanda e da oferta de trabalho no meio urbano. Esse modelo, entretanto, apesar de representar adequadamente o comportamento dos produtores rurais quando expostos a mudanças em algumas variáveis macroeconômicas, não tem sido utilizado em pesquisas empíricas relacionadas ao gerenciamento de propriedades rurais. 
Outra corrente teórica que procura explicar o processo de tomada de decisão de produtor rural é a Teoria do Comportamento Adaptativo do Produtor ${ }^{20}$, desenvolvida pelo pesquisador francês Petit, em meados da década de 70. Ela se fundamenta em quatro conceitos básicos: situação, objetivos, percepção e dupla adaptação. Em síntese, o modelo pressupõe que o conjunto de objetivos do produtor é influenciado pela situação do ambiente (com seus aspectos restritivos e facilitadores), pela situação do produtor (com suas habilidades e deficiências) e, principalmente, pela percepção que o próprio produtor tem sobre sua situação pessoal e do ambiente. É através dessa percepção que o produtor toma decisões, através de um processo arbitral entre os objetivos e a situação, ou seja, a decisão envolve de um lado os objetivos do produtor e de sua família e de outro a possibilidade que ele tem de os realizar, dado a sua situação. No processo de gestão o produtor considera, simultaneamente, as necessidades de investimento e manutenção na propriedade e as necessidades de consumo da família. A dupla adaptação se caracteriza pelas modificações nos objetivos em função das mudanças ocorridas na situação do ambiente ou na situação familiar. Os objetivos, hierarquizados subjetivamente, se modificam no tempo a fim de se adequarem às mudanças no ambiente e no contexto familiar. Assim, pode-se dizer que o produtor rural é o próprio agente e objeto da decisão.

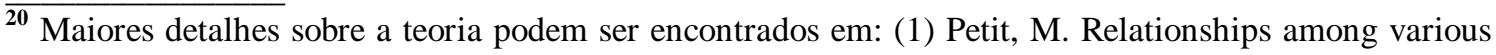
aspects of agricultural changes. European review of Agricultural economics. v.1, n.3, 1976. p. 163-186. (2) Petit, M. Theorie de la decision et comportement adaptatif des agriculteurs. In: Formation des agriculteurs et apprentissage de la decision. Actes de la journee d' étude du 21 janvier 1981. Dijon, ENSSAA, INPSA, INRA, INRAP. (3) Bonneviale, J.R. et al. Approche globale de l'exploitation agricole. Paris, INRAP, 1989, 329p.
} 


\subsection{O processo de coorientação entre produtores e assistência técnica}

A coorientação ${ }^{21}$ de atitudes entre os produtores rurais e os profissionais que trabalham com assistência técnica e extensão rural tem merecido a atenção de alguns autores. Guadagnin (1995), por exemplo, avalia o processo de comunicação interpessoal entre três grupos de indivíduos (produtores rurais, extensionistas e pesquisadores) participantes do Programa de Gestão Agrícola conduzido pela Empresa de Pesquisa Agropecuária do Estado de Santa Catarina - EPAGRI. No trabalho, o autor utiliza o modelo de coorientação proposto por McLeod e Chaffe (1973) para avaliar o processo de comunicação interpessoal entre os três grupos e o modelo de análise proposto por Groot (1970), que trata de forma quantitativa as variáveis concordância, congruência e precisão do processo de comunicação. Em suas conclusões, o autor destaca a baixa coorientação do processo de comunicação usado entre os grupos participantes do Programa, sobretudo entre produtores e extensionistas, fato que contribuiu negativamente para o processo de adoção de inovações relacionadas a técnicas de gestão das propriedades rurais. Diante disso, o autor sugere que futuras pesquisas procurem avaliar melhor os motivos para essa ineficiência identificada no processo de comunicação. O mesmo autor argumenta ainda que a comunicação praticada entre os grupos do Programa não tem adequadamente considerado as ambições, perspectivas e pontos de vista dos produtores rurais, contribuindo para a baixa utilização de técnicas de administração rural nas propriedades, pois os produtores, além de índices de

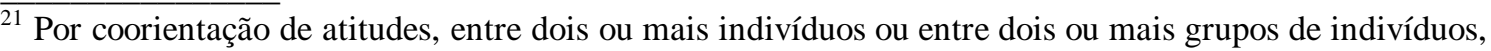
entende-se a similaridade de conhecimentos sobre o processo de comunicação existente entre eles. $\mathrm{O}$ modelo de coorientação proposto por McLeod e Chaffee (1973) considera que a comunicação interpessoal entre duas ou mais pessoas pode ser analisada através de três variáveis básicas: a concordância ou compreensão, a congruência e a precisão. A concordância ou compreensão indica a similaridade de conhecimento entre as pessoas sobre um dado objeto ("o que ambos pensam ou conhecem"). A congruência indica o grau de similaridade entre o conhecimento de um indivíduo sobre um dado objeto e sua estimativa sobre o conhecimento de outro indivíduo sobre o mesmo objeto ("o que um acha que o outro conhece"). Por fim, a precisão indica o grau de exatidão, entre a estimativa de um indivíduo sobre o conhecimento de outro indivíduo sobre um objeto, e o real conhecimento desse último sobre o objeto em questão ("o que um realmente sabe sobre o que o outro pensa ou conhece"). Vale ressaltar que a comunicação perfeita é aquela de maior precisão. Atingido esse nível, as pessoas poderiam discordar uma da outra, mas saberiam efetivamente em que e porque estão discordando.
} 
desempenho técnico-econômico, consideram também outros fatores, componentes e valores na administração de suas empresas.

Geraldo (1991) avaliando o programa de administração rural (PAR) da Emater-MG, por meio de uma amostra intencionalmente selecionada de 22 produtores rurais da região de Lavras-MG e os respectivos 22 técnicos (extensionistas) que os assistem, concluiu que a atitude favorável dos técnicos perante o programa tem grande influência na adoção de práticas administrativas por parte dos produtores rurais, com conseqüentes reflexos positivos em sua eficiência gerencial. No estudo, o termo atitude foi considerado como sendo uma maneira de pensar, sentir e reagir em relação a um objeto, o qual estava relacionado às crenças sobre o objeto (o componente cognitivo), à emoção ligada ao objeto (o componente afetivo) e à disposição para agir diante do objeto (o componente tendência à ação). Para a discriminação da variável atitude (mais favorável ou menos favorável) dos técnicos perante o referido programa foram considerados os aspectos cognitivos, afetivos e de tendência à ação, quantificados através de uma escala de valores, conforme proposto por Likert. Foram tabuladas manifestações emitidas pelos técnicos acerca de 48 questões relacionadas ao tema. Com relação ao componente cognitivo, procurou-se identificar e compreender as crenças e o conhecimento dos técnicos sobre a ciência da administração rural (conceitos, teorias e aplicações no processo de tomada de decisões) e sobre algumas questões do referido programa (seus objetivos, suas utilidades para o produtor, suas limitações e a dificuldade dos técnicos em utilizar-se das informações do programa para assessorar os produtores). Com relação ao componente afetivo, procurou-se identificar os sentimentos de aceitação ou rejeição do programa pelos técnicos e, com relação ao componente tendência para ação, procurou-se identificar a maior ou menor disposição dos técnicos para agir de acordo com o programa.

Os resultados do estudo de Geraldo indicaram também que existe uma diferença significativa entre as atitudes dos técnicos perante o programa e que essa ocorre, em maior ou menor grau, em todos os componentes de atitude considerados. Na 
pesquisa, vale ressaltar, os extensionistas com menor conhecimento cognitivo, apontaram algumas dificuldades para a execução do PAR, como por exemplo: "interpretação das informações do computador"; "análise dos dados finais com o produtor" e "passagem das informações para o produtor". Já os extensionistas de maior conhecimento cognitivo apontaram as seguintes dificuldades para a execução do PAR: "coleta dos dados"; "anotação inadequada do produtor", "demora do retorno das informações"; "seleção do produtor" e "fidedignidade dos dados".

Geraldo constata, ainda, a existência de uma associação direta entre a atitude do extensionista em relação ao PAR e a utilização das informações do programa pelo produtor rural. Dentre as justificativas apresentadas pelos produtores para a não utilização das informações, encontra-se muitos argumentos relacionados a atitudes desfavoráveis dos técnicos perante o programa, tais como: "Não foi dada importância pelo técnico, parece que fez o trabalho apenas cumprindo uma obrigação"; "O técnico não trouxe o papel para eu ver, apenas falou que tudo estava dando prejuízo”; "O técnico pediu que eu fosse anotando os dados e depois não apareceu mais para tratar desse assunto"; "O trabalho teria de ser levado a sério pelo técnico"; "Porquê o técnico não explicou para que servia este programa”; "Não fui bem esclarecido, por isso não vi vantagem”. Por fim, o estudo constata que existe uma associação direta entre a eficiência gerencial do produtor e a utilização das informações do programa.

Ainda no trabalho de Geraldo, merecem destaque algumas sugestões do autor ao final do estudo, que são relacionadas, principalmente, ao componente cognitivo da atitude dos extensionistas. Desta forma, o autor sugere esforços no sentido de: propiciar capacitação dos extensionistas em aspectos relacionados à operacionalização do PAR e à "ciência" da administração rural; promover oportunidades de troca de experiências entre os extensionistas e tornar o processo de operacionalização do PAR mais dinâmico, propiciando resultados mais imediatos. 
O trabalho de Geraldo confirma que a atitude dos técnicos com relação à área de administração rural influencia significativamente o processo de adoção de técnicas de gestão pelos produtores rurais. O enfoque de seu estudo, entretanto, é direcionado aos serviços públicos de assistência técnica e extensão rural (no caso a Emater-MG), onde a forma de ação dos técnicos e as características da empresa em que trabalham são influenciadas por várias questões, tais como: (a) forte e permanente influência das chefias regionais ou estaduais na determinação das prioridades de trabalho dos técnicos de campo; (b) imposição de "cima para baixo" dos programas desenvolvidos pela empresa a fim de se adequarem às políticas do governo em exercício; (c) o público prioritário de atendimento é o produtor rural de menor renda e instrução. Neste sentido, cabe analisar se as conclusões de Geraldo podem ser transpostas para os serviços privados de assessoria aos produtores rurais comerciais, como por exemplo, àqueles realizados por meio: de cooperativas agropecuárias; empresas com sistema de integração "produtor-indústria"; de escritórios particulares de planejamento e assistência técnica; de profissionais autônomos; entre outros. Essa análise se torna relevante, pois na atualidade tem-se observado, por parte dos produtores rurais comerciais, um potencial crescimento na demanda por serviços de assistência agropecuária mais abrangentes, incluindo questões de ordem econômica, administrativa, jurídica, ambiental, entre outras. Entretanto, esse tipo de assistência não tem sido priorizado pelas entidades públicas de assistência técnica e extensão rural, levando esses produtores a direcionarem sua demanda aos técnicos da iniciativa privada, hoje, aliás, representando a maioria deste tipo de força de trabalho presente no meio rural. Segundo dados contidos no estudo de Olinger (1998), ao longo da década de 70, a força de trabalho do sistema público de extensão rural (federal e estadual) chegou a representar cerca de $80 \%$ do total dos técnicos ligados às ciências agrárias atuando no campo diretamente nas propriedades e comunidades rurais; ao final dos anos 80, essa força de trabalho já representava menos de $20 \%$ do total, sendo substituída por profissionais vinculados às prefeituras, cooperativas agropecuárias, agroindústrias, organizações privadas, entre outras. 
Em parte, a demanda por uma assistência agropecuária mais abrangente vem sendo atendida, experimentalmente, através da assistência a grupos de produtores em algumas cooperativas agropecuárias e empresas privadas integradas ao setor rural. A dita "experiência", que geralmente envolve a "terceirização" de seus departamentos técnicos, visa transformar os profissionais em "consultores" relativamente autônomos, dos quais são exigidos serviços mais abrangentes relativamente à situação anterior. Nesse novo modelo os técnicos realizam, além da tradicional assistência aos produtores na área de definição dos sistemas de produção, também o apoio em outras questões relacionadas ao desempenho econômico das propriedades e a sustentabilidade dos empreendimentos rurais. Tem havido, porém, uma dificuldade na ação desses profissionais, principalmente em função da pouca experiência que possuem com esse tipo de trabalho.

No Brasil, a maior parte dos estudos e iniciativas com enfoque no gerenciamento de propriedades rurais esteve, até o momento, voltada à unidades de produção familiar. Esse direcionamento dos estudos e iniciativas tem sido justificados, normalmente, pela maior representatividade desse grupo de produtores rurais em termos numéricos relativamente ao total de propriedades rurais do país. E também pela sua condição de comporem um público alvo com maior relevância social, sendo, portanto, objeto de análise preferencial para as instituições públicas e programas de governo. Nesse contexto, alguns esforços têm sido marcantes, tais como os realizados por algumas universidades (UFLA, UNIJUÍ, etc), por algumas unidades do sistema oficial de extensão rural (EMATER-MG, EPAGRI-SC, etc) e por alguns centros de pesquisa agropecuária (EMBRAPA, entre outros) ${ }^{22}$.

Segundo LIMA et al. (1995), as iniciativas que foram ou vêm sendo desenvolvidas no país para aprimorar e difundir a área de administração rural, embora

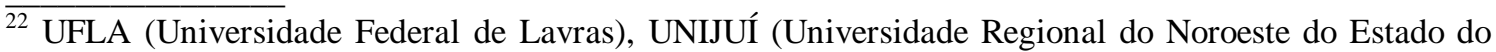
Rio Grande do Sul), EMATER-MG (Empresa de Assistência Técnica e Extensão Rural do Estado de Minas Gerais), EPAGRI-SC (Empresa de Pesquisa Agropecuária de Santa Catarina) e EMBRAPA (Empresa Brasileira de Pesquisa Agropecuária). 
ainda não devidamente sistematizadas e analisadas, apresentam diferentes concepções e estratégias de trabalho. No campo específico das experiências que buscam trabalhar com os agricultores, os autores identificam três proposições básicas: (a) a perspectiva da difusão de tecnologia gerencial para os agricultores; (b) a preocupação com a assistência gerencial e econômica aos agricultores; e (c) a proposta de formação econômica e administrativa dos agricultores.

As proposições de trabalho com os agricultores possuem as seguintes características: (a) a perspectiva da difusão de tecnologia gerencial, normalmente adotada pelas entidades do sistema oficial de extensão rural, considera que o agricultor adota procedimentos inadequados na administração de suas atividades, sendo, portanto, necessárias ações para difundir aos agricultores um conjunto de métodos e técnicas gerenciais, por meio de capacitação que vise melhorar o uso de técnicas de controle e de análise econômica, financeira e de planejamento; (b) a preocupação com a assistência gerencial e econômica aos agricultores considera que a atual complexidade da agricultura moderna não permite mais que o agricultor administre suas atividades sem assessoria, sendo, portanto, indispensável aos técnicos prestar-lhes assistência de natureza técnica, econômica e financeira. Essa estratégia de trabalho, normalmente, é defendida pelos profissionais autônomos e pelas empresas privadas de planejamento e assistência técnica; e (c) a proposta de formação econômica e administrativa dos agricultores fundamenta-se no pressuposto de que uma sólida formação econômica e gerencial dos agricultores é indispensável para a eficácia de seus negócios. O sistema SENAR (Serviço Nacional de Aprendizagem Rural) e algumas ONGs - organizações não governamentais - seguem, em parte, essa filosofia.

Rockenback (1995) realizou estudo em 12 empresas familiares rurais do Estado de Santa Catarina com o objetivo de verificar o grau de participação da mulher nos processos produtivo e administrativo da empresa rural e sua influência no resultado econômico dessas empresas. No estudo, o termo participação referia-se à condição de estar presente e atuando e o termo influência referia-se a condição de variação de um 
resultado em função da participação. As funções administrativas consideradas no estudo foram o planejamento, organização, direção e controle. Já o termo processo produtivo foi definido como sendo a interação de todas as atividades relacionadas diretamente com a produção e necessárias para a obtenção dos produtos e serviços, envolvendo desde a aquisição dos insumos, estocagem dos produtos e transferência da produção ao mercado. Para a avaliação sobre a participação da mulher no processo produtivo, o estudo discriminou as principais tarefas componentes do sistema de produção e o tempo padrão necessário à execução de cada tarefa para as principais atividades da propriedade. Obteve-se assim, por entrevista aos produtores, a participação percentual da mulher no processo produtivo, que resultou em valores entre um mínimo de $3 \%$ e um máximo de 37\%. Quanto à avaliação sobre a participação da mulher no processo administrativo, o procedimento utilizado envolveu a elaboração de uma lista de ações administrativas de planejamento, organização, direção e controle, que foi submetida a quinze especialistas em administração rural. Utilizando a metodologia de juízes, atribuíram valores a cada ação administrativa de acordo com seu julgamento pessoal sobre a importância de cada ação para as empresas rurais em pauta. Foi construído um índice que foi utilizado para se determinar a participação da mulher no processo administrativo, chegando-se a valores entre um mínimo de $25 \%$ e um máximo de $38 \%$. Quanto à influência da mulher no resultado econômico, o estudo não encontrou evidências estatísticas (relações significativas) para concluir sobre o assunto.

No trabalho de Rockenbach vale comentar o interessante esforço metodológico no sentido de separar, em termos quantitativos, o grau de participação de diferentes pessoas no processo produtivo e administrativo de uma empresa rural. No entanto, com relação às ações administrativas relacionadas no estudo (que representam um total de 33 ações), não houve o devido cuidado metodológico que permitisse uma análise separada das diferentes ações administrativas de planejamento (12 ações); de organização (4 ações); de direção (8 ações) e de controle (9 ações), nem tampouco uma distinção com relação aos níveis empresariais estratégico e operacional dessas ações. 
Vale (1995) em estudo sobre a avaliação de sistemas de informação para produtores rurais, procurou levantar as principais fontes de informações (institucionais) usadas por produtores rurais participantes do Programa da Pecuária Leiteira da Região de Viçosa (PDPL-RV) em seu processo de tomada de decisão. Foram consideradas questões de ordem técnica (sistema de produção, insumos, alimentação, sanidade e manejo), de ordem comercial (preços, mercado) e de ordem financeira (investimentos, financiamentos). No levantamento de campo, entretanto, foram aplicados questionários abertos, onde os produtores podiam indicar mais de uma resposta sem identificar o grau de participação de cada fonte de informação (institucional), dentre as seguintes opções relacionadas: cooperativa, serviço de extensão, técnicos e estagiários do PDPL-RV, vendedores, vizinhos, televisão, rádio, revista, jornal, própria experiência, universidade e outras. Dessa forma, o dados resultantes do questionário aplicado não permitem identificar, com precisão, o grau de influência dos profissionais que atuam na assistência técnica e extensão rural no processo de decisão dos produtores rurais. Uma aproximação desse grau de influência, no entanto, pode ser obtida se forem agregadas algumas fontes de informação consideradas no estudo.

Reclassificando os dados originais de Vale pode-se considerar, a título de aproximação, que as fontes de informação classificadas como "cooperativa", "serviço de extensão" e "técnicos e estagiários do PDPL-RV" dizem respeito à atuação dos profissionais mais diretamente relacionados à assistência técnica e extensão rural. $\mathrm{O}$ grau de influência desses profissionais no total das respostas dos produtores apresenta importância diferente conforme as questões consideradas. De uma certa forma, pode-se concluir que a assistência técnica tem se envolvido mais com questões tecnológicas do que com questões de ordem financeira e comercial. Para a definição dos sistemas de produção, por exemplo, os produtores participantes do PDPL-RV recorrem a informações da assistência técnica em 45,62\% dos casos, fazendo dela sua principal fonte de informação. No caso da definição dos sistemas de produção, a informação obtida junto aos meios de comunicação representa 17,52\% dos casos. A própria experiência participa com 22,81\% dos casos e outras fontes de informação com 14,05\% 
dos casos. Já para as questões de ordem comercial a informação obtida junto à assistência técnica é de 31,60\% dos casos referentes ao conhecimento dos preços e de $30,91 \%$ dos casos referentes ao conhecimento sobre a situação dos mercados. Para questões de ordem financeira, a participação da assistência técnica, enquanto uma fonte de informação, é de 39,62\% para o caso de decisões de investimento e de apenas 19,63\% para o caso de decisões de financiamento. (tabela 1).

\subsection{O processo de aconselhamento gerencial aos produtores}

$\mathrm{Na}$ literatura brasileira existem poucos trabalhos com o objetivo de orientar os profissionais da assistência técnica e extensão rural no processo de aconselhamento gerencial aos produtores rurais. Dentre eles destaca-se o de Lima et al. (1995) que procuram desenvolver um roteiro que possa facilitar a ação dos técnicos junto aos agricultores familiares. Eles afirmam que o processo de aconselhamento aos produtores, apesar de ser "clássico" e aparentemente simples, tem se constituído em um dos principais pontos de estrangulamentos da ação dos técnicos. Em linhas gerais, a formulação do "conselho" aos produtores rurais é precedida pela fase de observação da propriedade rural, da fase de sistematização dos dados e informações coletadas e da fase de interpretação e análise da situação vigente. Observa-se que estamos utilizando o termo "conselho" para denotar as interferências típicas de consultores ou de consultoria. O conselho é uma proposta de intervenção no processo de desenvolvimento da propriedade rural para confirmar ou transformar a tendência verificada. 
Tabela 1. Participação percentual de diferentes fontes de informação utilizadas por produtores rurais participantes do PDPL-RV segundo algumas questões de ordem tecnológica, comercial e financeira, Minas Gerais, 1994.

\begin{tabular}{lccccc}
\hline \multicolumn{1}{c}{ Itens } & $\begin{array}{c}\text { Assistência } \\
\text { Técnica } \\
(1)\end{array}$ & $\begin{array}{c}\text { Comunicação } \\
\text { de Massa } \\
(2)\end{array}$ & $\begin{array}{c}\text { Própria } \\
\text { experiência }\end{array}$ & $\begin{array}{c}\text { Outros } \\
(4)\end{array}$ & Total \\
& & & & & \\
\hline Questões tecnológicas & 45,62 & 17,52 & 22,81 & 14,05 & 100,00 \\
SISTEMAS DE PRODUÇÃO & 46,29 & 11,08 & 20,38 & 22,25 & 100,00 \\
INSUMOS & 50,89 & 15,79 & 24,56 & 8,76 & 100,00 \\
ALIMENTAÇÃO & 55,38 & 12,49 & 21,45 & 10,68 & 100,00 \\
SANIDADE & 43,40 & 9,42 & 32,07 & 15,10 & 100,00 \\
MANEJO & & & & & \\
& & & & & 100 \\
Questões Comerciais & 31,60 & 43,87 & 5,25 & 19,29 & 100,00 \\
PREÇOS & 30,91 & 23,63 & 29,11 & 16,35 & 100,00 \\
MERCADO & & & & & \\
& & & & & \\
Questões Financeiras & 39,62 & 14,58 & 33,33 & 12,47 & 100,00 \\
INVESTIMENTO & 19,63 & 35,29 & 17,64 & 27,44 & 100,00 \\
FINANCIAMENTO & & & & & \\
\hline
\end{tabular}

Fonte: adaptado de Vale (1995), p. 82.

As fontes de informação foram agregadas da seguinte forma: (1) cooperativa, extensão, técnicos e estagiários do PDPL-RV; (2) Televisão, rádio, revista e jornal; (3) Vizinhos e própria experiência; e (4) Vendedores, Universidade e outras fontes.

Segundo Mazoyer (1985), o conselho pode ser constituído por diferentes proposições, entre as quais destacam-se: a proposição que visa melhorar o nível de eficácia técnica das atividades desenvolvidas; a proposição que visa melhorar o nível de eficácia gerencial da atividade produtiva e do financiamento dos recursos e das atividades da unidade de produção; a proposição que visa melhorar as condições de trabalho e o potencial produtivo das culturas e criações; a proposição que visa melhorar a capacidade de financiamento da unidade de produção; e a proposição que visa 
melhorar ou criar as condições macroeconômicas e estruturais para o desenvolvimento de longo prazo de unidades de produção que se encontram em processo de estagnação ou em crise. Após a definição do caráter do conselho, é necessário identificar as alternativas possíveis, proceder a sua avaliação técnica, econômica e financeira e elaborar o plano de implementação da alternativa escolhida. (Lima et al, 1995, p.147$151)$.

A linha de trabalho apresentada por Lima et al. (1995) trata da abordagem denominada "sistêmica" cuja metodologia assemelha-se a técnicas de planejamento estratégico. Ela é realizada por meio de uma análise do ambiente externo à propriedade e de um diagnóstico interno rápido, feito a partir de entrevista com os agricultores, visando identificar o funcionamento da unidade de produção e suas potencialidades e estrangulamentos. Trata-se de uma metodologia interessante, sobretudo pelo pouco tempo existente entre o início dos trabalhos e o repasse de conselhos aos produtores. Ela, no entanto, exige grande experiência dos consultores para o seu sucesso, a menos que o problema identificado coincida com a "especialidade" do consultor. Além disso, o ideal é que o aconselhamento não represente um fim em si mesmo, mas que seja acompanhado por outras análises mais detalhadas, realizadas tanto de forma "ex-ante" como de forma "ex-post", tornando o aconselhamento gerencial um processo contínuo e recorrente.

Gray et al (1999) destacam que pouco é conhecido sobre a forma de "trabalho de campo" dos consultores rurais, em relação ao processo que usam "na prática" para resolver os problemas dos produtores. Os autores descrevem o rol de procedimentos, utilizados por dois experientes consultores rurais da Nova Zelândia, por ocasião da visita aos seus clientes. Em sequiência, o trabalho dos consultores envolve as seguintes fases: o primeiro contato, a preparação antes da visita, a chegada à propriedade, a conversa inicial ("quebra-gelo"), a discussão preliminar, a inspeção da propriedade, a resolução do problema, o relatório e o acompanhamento pós-visita. Muitas vezes, a fase de preparação (antes da visita) inclui a análise dos dados 
financeiros, dos recursos físicos e humanos da propriedade, das metas da família do produtor e das práticas administrativas utilizadas. Ressaltam que o conhecimento prévio da situação contribui tanto para o reconhecimento, o diagnóstico e a definição do problema, como para a identificação das restrições e metas que determinam as opções possíveis. Os autores concluem que do tempo total gasto na consultoria, a maior parte ocorre na realização do diagnóstico da propriedade e uma pequena parte na análise de opções para a solução dos problemas. Os aspectos críticos sobre o processo de solução de problemas incluem: considerações sobre a relevância do conselho; elaboração do diagnóstico usando dados projetados e históricos; e a determinação da opção apropriada.

O trabalho de Attonaty et al (1999) discute uma série de métodos e ferramentas visando auxiliar produtores no processo de tomada de decisões baseados em modelos computacionais. Enfatiza o uso de métodos de simulação como meio para expandir a interatividade, ressaltando que ela não deve visar apenas a obtenção de soluções ótimas, mas sim produzir elementos para discussão entre produtores e consultores. Sobre a aplicação da programação linear em propriedades individuais, por exemplo, alerta para as seguintes dificuldades: consome muito tempo de modelagem, seus resultados são de difícil interpretação pelos produtores e de difícil repetição ao longo do tempo. Nesse caso, argumenta que o uso da programação linear visando o desenho de sistemas de referência, a partir de análises de empresas hipotéticas, seria mais útil para expandir a interatividade entre consultores e grupos de produtores. Ressalta ainda, que a programação linear deveria ser mais usada na administração rural como ferramenta de simulação (a fim de prover novos elementos para discussão) do que como ferramenta para otimização (a fim de prover soluções ótimas como um fim em si mesma).

Em suma, a revisão de literatura ora apresentada evidencia que os serviços privados de assessoria econômica e administrativa, a produtores rurais no Brasil, possuem uma série de desafios a serem superados. Merece destaque a falta de um referencial teórico e metodológico para o processo de aconselhamento, adaptado à 
realidade brasileira dos produtores rurais comerciais, tendo em vista a carência de estudos para esse público. Além disso, outras questões se mostraram relevantes: (a) a necessidade de se aperfeiçoar a gestão na propriedade rural; (b) a associação positiva entre gestão mais eficiente e melhor resultado econômico; (c) a multiplicidade e diversidade das organizações rurais e dos objetivos dos produtores; (d) a baixa coorientação de atitudes entre produtores e técnicos. Para a solução dessas questões, entretanto, faz-se necessário, além do estabelecimento de um referencial teórico, uma análise prévia sobre as seguintes questões: (1) sobre o perfil e atitudes dos produtores rurais e dos técnicos que os assistem na administração da empresa agropecuária; (2) sobre as dificuldades no processo de comunicação entre produtores e técnicos; e (3) sobre a identificação mais precisa dos fatores limitantes ao uso de técnicas de gestão nas empresas agropecuárias. 


\section{MODELO TEÓRICO}

A administração de uma empresa agropecuária envolve um grande número de atividades administrativas. Essas atividades podem ser agrupadas, conforme suas características, em determinadas funções administrativas. As funções administrativas, por sua vez, quando tomadas ou consideradas em conjunto, formam o chamado processo administrativo. A expressão abaixo ilustra esse esquema conceitual, onde o processo administrativo (PA) é função de uma série de funções administrativas $\left(\mathrm{FA}_{\mathrm{i}}\right)$, com $i$ variando de 1 a $n$, e estas, por sua vez, são funções de uma série de atividades administrativas $\left(\mathrm{AA}_{\mathrm{ji}}\right), \operatorname{com} j$ variando de $a$ a $z$.

$P A=f\left\{F_{1}\left(A_{a 1}, A_{b 1}, \ldots A_{z 1}\right) ; F_{2}\left(A_{a 2}, A_{b 2}, \ldots A_{z 2}\right) ; \ldots ; \mathrm{FA}_{n}\left(A_{a n}, A_{a n}, \ldots A_{z n}\right)\right\}$

Onde:

$\checkmark$ PA representa o processo administrativo da empresa;

$\checkmark \mathrm{FA}_{\mathrm{i}}$ representam as funções administrativas $i(1,2, \ldots, \mathrm{n})$ realizadas na empresa;

$\checkmark \mathrm{AA}_{\mathrm{ji}}$ representam as atividades administrativas $j i(\mathrm{a} 1, \mathrm{~b} 1, \ldots, \mathrm{z} 1 ; \mathrm{a} 2, \mathrm{~b} 2, \ldots, \mathrm{z} 2$; an, bn, ..., zn) relacionadas, respectivamente, a cada uma das diferentes funções administrativas $i(1,2, \ldots, \mathrm{n})$ realizadas na empresa.

$\mathrm{Na}$ literatura sobre administração rural existem algumas diferenças, nas denominações usadas pelos autores, para identificar quais são as funções administrativas que, em conjunto, formam o processo administrativo da empresa. As funções administrativas mais citadas na literatura são: a) planejamento, organização, direção e controle (Souza et al, 1990; entre outros); b) planejamento, organização, execução e 
controle (Guerra, 1985; entre outros) c) planejamento, execução e controle (Boehlje \& Eidman, 1984; entre outros). Sobre essas diferenças nas denominações das funções administrativas existentes na literatura, cabe ressaltar que elas não comprometem o entendimento global do assunto, pois quando tomadas em conjunto convergem para um consenso sobre o que representa o processo administrativo. As diferentes denominações utilizadas, portanto, correspondem muito mais à expressão das preferências pessoais dos autores pelo uso desse ou daquele termo, do que propriamente a discordâncias teóricas ou diferentes pontos de vistas no entendimento conceitual do processo administrativo como um todo.

Quanto a sua abrangência, as funções administrativas podem ser subdivididas conforme os diferentes níveis empresariais de decisão a que estão relacionadas. Souza et al., 1990, por exemplo, distingue três níveis empresariais: o nível institucional ou estratégico; o nível gerencial ou intermediário; e o nível operacional. $\mathrm{O}$ mesmo número de níveis empresariais também é considerado por Oliveira, 1999; mas os termos utilizados por esse autor são estratégico, tático e operacional. Já Boehlje \& Eidman, 1984; e Guerra, 1985; não fazem distinção de níveis empresariais em suas obras.

Em linhas gerais, o nível institucional ou estratégico compreende decisões de longo prazo (do tipo "o que fazer" e "quando fazer") tomadas por pessoas responsáveis pelos assuntos globais da empresa, como os proprietários, diretores, sócios gerentes, etc. Nesse nível, as decisões envolvem a formulação dos objetivos gerais da empresa e a seleção das estratégias para atingi-los adequadamente, levando-se em consideração as condições externas e internas à empresa. Nesse ponto, merece distinção os termos estratégia empresarial e ação empresarial. Estratégia está relacionada à definição dos objetivos da empresa. Sua formulação compreende a alocação eficiente dos recursos físicos, financeiros, mercadológicos e humanos da empresa e a análise das oportunidades e ameaças do ambiente, visando alcançar as metas estabelecidas pelo empresário. A ação empresarial, por sua vez, se refere à implementação da estratégia 
empresarial através da execução das funções administrativas, tais como: o planejamento, a organização, a direção e o controle.

O nível intermediário, gerencial ou tático compreende, normalmente, decisões de médio prazo (do tipo “como fazer”), que são tomadas por pessoas de nível intermediário na hierarquia funcional da empresa como gerentes, administradores, capatazes, técnicos, entre outros. Nesse nível intermediário, as decisões normalmente se orientam para a utilização eficiente dos recursos disponíveis, a fim de atingir os objetivos estabelecidos ao nível institucional ou estratégico. Por fim, o nível operacional compreende, normalmente, decisões de curto prazo relacionadas às mais diversas operações e tarefas do dia-a-dia da empresa, tendo como base às decisões definidas ao nível intermediário. Sobre essa classificação dos níveis empresariais, deve-se destacar sua natureza de relatividade ou imprecisão de suas linhas demarcatórias quanto aos prazos, amplitudes, riscos e flexibilidades das respectivas decisões em cada nível. Normalmente, as decisões institucionais ou estratégicas envolvem um prazo mais longo, uma maior amplitude, um maior risco e uma menor flexibilidade em relação às decisões gerenciais, táticas ou intermediárias. Entretanto, o mesmo pode-se dizer sobre as decisões gerenciais, tática ou intermediária, em relação às decisões de nível operacional.

Diante do exposto, nesse estudo optou-se por discutir o processo administrativo das empresas agropecuárias considerando os níveis empresariais estratégico e operacional, sendo nesse último incorporado as características do nível intermediário definido por alguns autores, e quatro funções administrativas: planejamento, organização, direção e controle.

O termo planejamento pode ser entendido como um trabalho de preparação para qualquer empreendimento, segundo roteiro e métodos determinados que procuram antever as conseqüências de uma ação. A função de planejamento empresarial pode ser entendida como um processo que leva ao estabelecimento de um conjunto ordenado de ações ou plano, pela direção de uma empresa, visando à consecução de 
determinados objetivos como, por exemplo, a maximização de resultados e a minimização de deficiências. No âmbito das empresas agropecuárias, a função planejamento será discutida, com mais detalhes, nos itens 5.2.1e 6.3.

As outras três funções tratam da implementação dos planos. A organização, enquanto função administrativa, se preocupa em agrupar e estruturar todos os recursos disponíveis na empresa para viabilizar o funcionamento do sistema de produção de forma eficiente. Essa função será discutida nos itens 5.2.2 e 6.4. A função administrativa de direção compreende o ato de comandar, gerir ou dirigir uma empresa, e será discutida nos itens 5.2.3 e 6.5. Ela engloba, entre outras coisas, o ato de supervisionar o uso de todos os recursos da empresa, a fim de cumprir com a execução das ações planejadas. Finalmente, a função de controle, a ser discutida nos itens 5.2.4 e 6.6, é uma tarefa contínua de registrar e avaliar o desempenho de todas as atividades da empresa, a fim de se propor as correções necessárias, em tempo oportuno.

$\mathrm{Na}$ literatura sobre administração rural existem, também, algumas pequenas diferenças quanto aos termos utilizados pelos autores para identificar as diferentes áreas administrativas ou empresariais existentes nas empresas rurais. A classificação mais usual, no entanto, considera as seguintes áreas administrativas: área de produção; área de finanças; área de comercialização e "marketing”; e área de pessoal ou de recursos humanos. Cabe ressaltar, que todas as funções administrativas podem ser executadas em todas as áreas administrativas da empresa e nos diversos níveis empresariais. Tomando-se, por exemplo, a função organização, pode-se diferenciar a organização da área de recursos humanos da organização da área de produção, e da mesma forma, a organização estratégica da área de recursos humanos da organização operacional da mesma área, e assim por diante. Assim, na organização estratégica da área de recursos humanos se poderia retratar a estrutura funcional da mão-de-obra da empresa como um todo, abordando sua estrutura através de áreas e subáreas. Já na organização operacional da área de recursos humanos se poderia, por exemplo, detalhar 
os cargos e funções para cada um dos funcionários e membros da família na empresa agropecuária.

\subsection{Matriz de atividades administrativas}

A implementação ou realização das atividades administrativas em empresas agropecuárias faz parte de um processo dinâmico no tempo. É difícil para o produtor rural separar ou isolar, no dia a dia, a prática dessa ou daquela atividade administrativa. Muitas vezes, várias atividades administrativas são realizadas ao mesmo tempo. Isso ocorre, principalmente, pela forte interdependência que existe entre as diferentes funções administrativas e entre as diferentes áreas administrativas nas empresas agropecuárias. Corrobora também nesse sentido, a dificuldade do produtor rural em prever qual a seqüência exata das ações administrativas a serem tomadas ao longo do tempo, notadamente, em função das constantes mudanças nas variáveis do ambiente, que não podem ser controladas pelo produtor rural.

Alguns autores apresentam fluxogramas que ordenam as funções administrativas, estabelecendo, por exemplo, que a administração se inicia pelo planejamento, passa pela organização e depois pela execução e controle (Guerra, 1985). Esses fluxogramas, no entanto, se valem normalmente de setas de recorrência entre as funções do processo administrativo, indicando uma certa interdependência entre as atividades administrativas e uma característica de relação aparentemente circular entre as etapas ou funções do processo administrativo.

O Quadro 1 relaciona alguns exemplos genéricos de atividades administrativas realizadas em empresas agropecuárias. Ela procura distinguir e, também, relacionar as diferentes funções do processo administrativo (planejamento, organização, direção e controle), segundo os diferentes níveis de decisão (estratégico e operacional), com as diferentes áreas empresariais (produção, finanças, comercialização e recursos 
humanos) consideradas nesse estudo. Estão sendo considerados no Quadro 1, portanto, 32 subgrupos de atividades administrativas, como se fossem 32 elementos distintos de uma matriz de 8 linhas e 4 colunas. Nas oito linhas estão representadas as combinações possíveis das quatro funções administrativas e dos dois níveis empresariais, da seguinte forma: planejamento estratégico, planejamento operacional, organização estratégica, organização operacional, direção estratégica, direção operacional, controle estratégico e controle operacional. Nas quatro colunas estão representadas as áreas administrativas de produção, finanças, comercialização e de pessoal. No interior da "matriz 8x4", cada um dos 32 elementos representa as inúmeras atividades administrativas possíveis de serem realizadas, e que em conjunto formam o processo administrativo, conforme o esquema conceitual apresentado anteriormente. Dessa forma, o primeiro elemento da "matriz" (encontro da primeira linha com a primeira coluna) corresponde às atividades administrativas relacionadas ao planejamento estratégico da área de produção. Já o último elemento da "matriz" (encontro da oitava linha com a quarta coluna) corresponde às atividades administrativas relacionadas ao controle operacional da área de recursos humanos.

Apesar da dificuldade em se estabelecer uma exata seqüência cronológica e ordinal para a realização das atividades administrativas pelo produtor rural, a visualização segmentada dessas atividades em 32 subgrupos ou elementos distintos, conforme apresentado no Quadro 1, pode auxiliar na compreensão do complexo e dinâmico processo que é a administração de uma empresa agropecuária. A melhor compreensão do processo administrativo com o estabelecimento de 32 subgrupos de atividades administrativas pode ocorrer, por exemplo, pelos seguintes motivos: (a) pela mais fácil identificação de algumas atividades administrativas que não estão (mas deveriam estar) sendo realizadas pelo produtor rural; (b) pela mais fácil identificação de atividades administrativas que estão sendo realizadas de forma ineficiente e precisam ser corrigidas; (c) pela mais fácil identificação de atividades administrativas que não são relevantes para o sistema de produção da empresa e, portanto, não precisam ser realizadas ou pelo menos não necessitam de grande atenção por parte do produtor rural. 
Quadro 01 - Identificação de atividades administrativas realizadas em empresas agropecuárias. Dois exemplos genéricos de atividades administrativas para cada uma das diferentes funções do processo administrativo e das diferentes áreas administrativas da empresa agropecuária.

\begin{tabular}{|c|c|c|c|c|}
\hline $\begin{array}{l}\text { Áreas administrativas } \\
\text { Funções administrativas }\end{array}$ & Produção & Finanças & Comercialização & Pessoal \\
\hline $\begin{array}{l}\text { Planejamento } \\
\text { Estratégico }\end{array}$ & $\begin{array}{l}\Rightarrow \text { Identificar e definir as ativida- } \\
\text { des (culturas e criações) a serem } \\
\text { realizadas pela empresa, } \\
\text { considerando fatores como: as } \\
\text { disponibilidades e as exigências } \\
\text { de recursos; os riscos e as } \\
\text { rentabilidades potenciais; as } \\
\text { ameaças e as oportunidades do } \\
\text { ambiente; e os gostos e as prefe- } \\
\text { rências do produtor rural e sua } \\
\text { família. } \\
\Rightarrow \text { Projetar o desempenho produ- } \\
\text { tivo da empresa e a alocação } \\
\text { dos recursos necessários a } \\
\text { produção. }\end{array}$ & 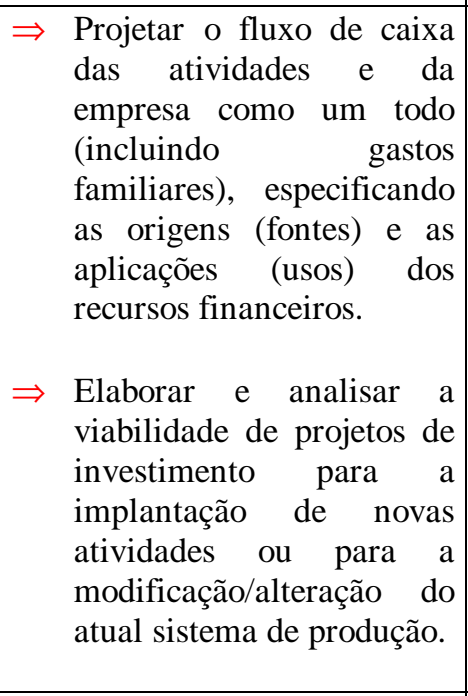 & 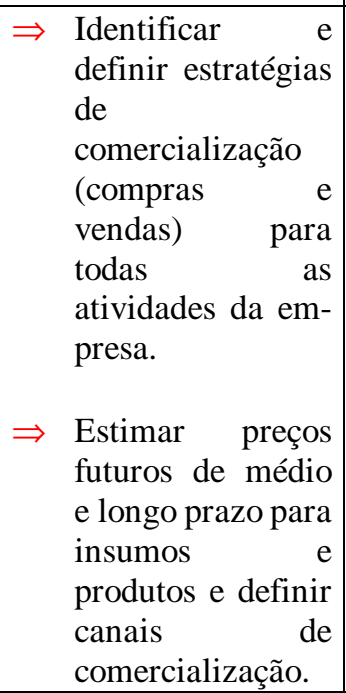 & $\begin{aligned} & \Rightarrow \begin{array}{l}\text { Estimar o balanço de } \\
\text { oferta e demanda de } \\
\text { mão-de-obra para a } \\
\text { empresa. }\end{array} \\
& \Rightarrow \text { Definir a estratégia da } \\
& \text { empresa para a seleção, } \\
& \text { recrutamento } \\
& \text { treinamento da mão- } \\
& \text { de-obra. }\end{aligned}$ \\
\hline $\begin{array}{c}\text { Planejamento } \\
\text { Operacional }\end{array}$ & 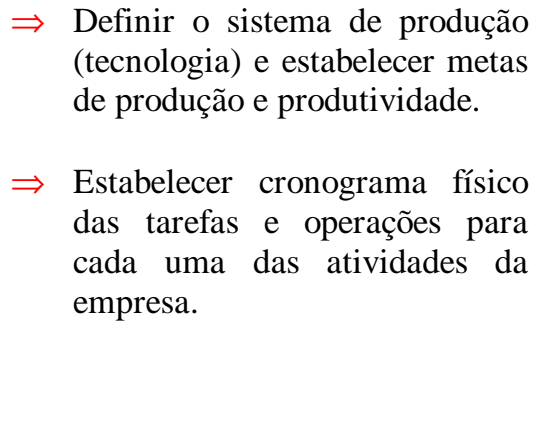 & $\begin{array}{l}\Rightarrow \text { Elaborar orçamentos para } \\
\text { as atividades da empresa. } \\
\Rightarrow \begin{array}{l}\text { Estabelecer cronograma } \\
\text { financeiro para as ativida- } \\
\text { des da empresa. }\end{array}\end{array}$ & 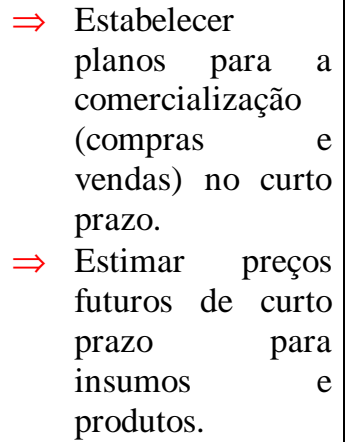 & $\begin{aligned} \Rightarrow & \text { Prever a } \\
& \text { disponibilidade e exi- } \\
& \text { gência de mão-de-obra } \\
& \text { para as atividades da } \\
& \text { empresa. } \\
\Rightarrow & \text { Estabelecer para a } \\
& \text { mão-de-obra as ações } \\
& \text { necessárias para a } \\
& \text { execução dos planos de } \\
& \text { produção. }\end{aligned}$ \\
\hline
\end{tabular}


Quadro 01 - Identificação de atividades administrativas realizadas em empresas agropecuárias. Dois exemplos genéricos de atividades administrativas para cada uma das diferentes funções do processo administrativo e das diferentes áreas administrativas da empresa agropecuária.

\begin{tabular}{|c|c|c|c|c|}
\hline $\begin{array}{r}\text { Áreas empresariais } \\
\text { Funções administrativas }\end{array}$ & Produção & Finanças & Comercialização & Pessoal \\
\hline $\begin{array}{c}\text { Organização } \\
\text { estratégica }\end{array}$ & 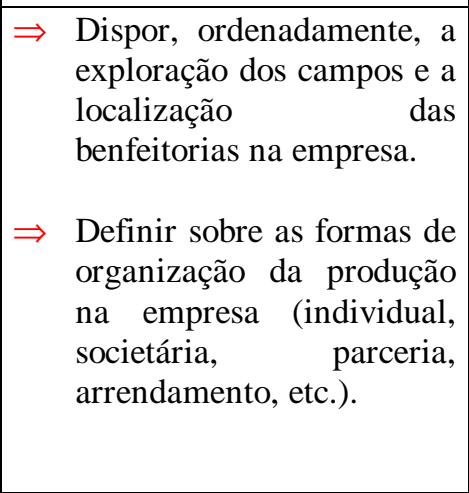 & $\begin{array}{l}\Rightarrow \begin{array}{l}\text { Definir os centros de } \\
\text { custos e/ou centros de } \\
\text { lucros da empresa. }\end{array} \\
\Rightarrow \begin{array}{l}\text { Definir e detalhar o } \\
\text { plano de contas da } \\
\text { empresa. }\end{array}\end{array}$ & 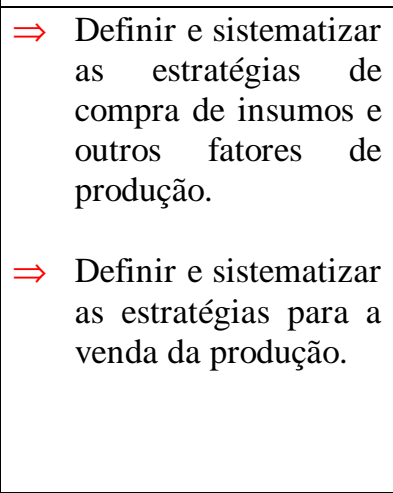 & $\begin{aligned} \Rightarrow \text { Estabelecer o organograma } \\
\text { funcional (atribuições) da } \\
\text { mão-de-obra, indicando a } \\
\text { interdependência e a hierar- } \\
\text { quia entre as pessoas, } \\
\text { secções ou áreas de } \\
\text { responsabilidades existentes } \\
\text { na empresa. } \\
\Rightarrow \text { Estabelecer planos de cargos } \\
\text { e salários para a mão-de- } \\
\text { obra. }\end{aligned}$ \\
\hline $\begin{array}{c}\text { Organização } \\
\text { operacional }\end{array}$ & 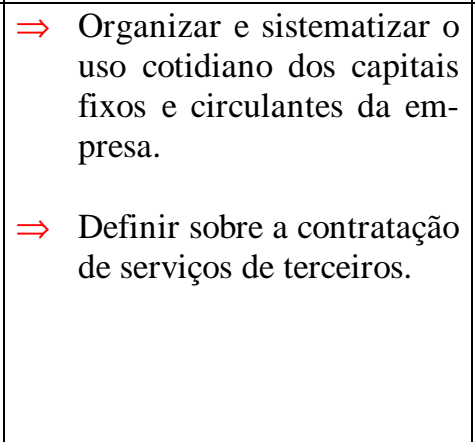 & $\begin{aligned} & \Rightarrow \text { Organizar e } \\
& \text { sistematizar o fluxo } \\
& \text { de informações finan- } \\
& \text { ceiras da empresa. }\end{aligned}$ & $\begin{array}{l}\text { Organizar sistemas } \\
\text { para a identificação e } \\
\text { seleção de clientes e } \\
\text { de fornecedores de } \\
\text { bens e serviços. }\end{array}$ & $\begin{array}{l}\Rightarrow \text { Distribuir adequadamente no } \\
\text { tempo e no espaço as tarefas } \\
\text { da mão-de-obra. }\end{array}$ \\
\hline
\end{tabular}


Quadro 01: Identificação de atividades administrativas realizadas em empresas agropecuárias. Dois exemplos genéricos de atividades administrativas para cada uma das diferentes funções do processo administrativo e das diferentes áreas administrativas da empresa agropecuária.

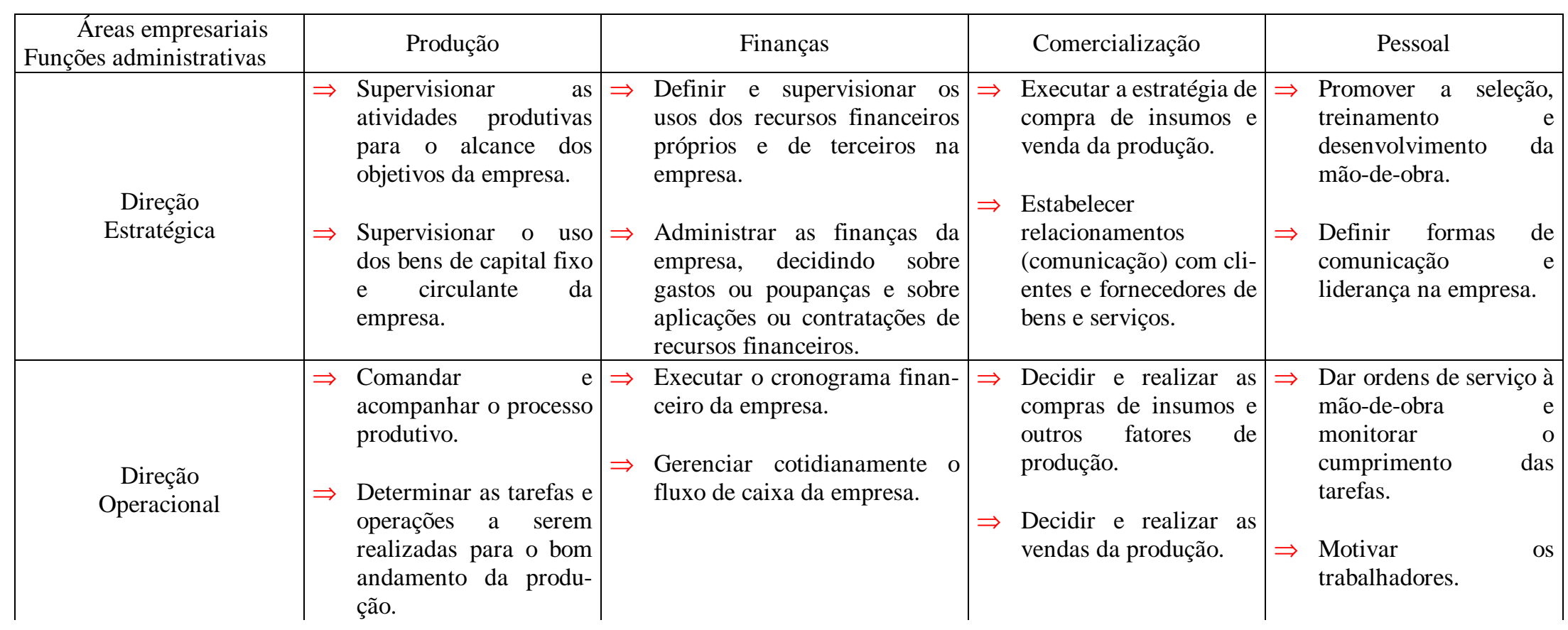


Quadro 01: Identificação de atividades administrativas realizadas em empresas agropecuárias. Dois exemplos genéricos de atividades administrativas para cada uma das diferentes funções do processo administrativo e das diferentes áreas administrativas da empresa agropecuária.

\begin{tabular}{|c|c|c|c|c|}
\hline $\begin{array}{l}\text { Áreas empresariais } \\
\text { Funções administrativas }\end{array}$ & Produção & Finanças & Comercialização & Pessoal \\
\hline $\begin{array}{l}1.1 \text { Controle } \\
\text { estratégico }\end{array}$ & $\begin{aligned} \Rightarrow & \begin{array}{l}\text { Coletar e sistematizar } \\
\text { dados relacionados à }\end{array} \\
& \begin{array}{l}\text { produção global da } \\
\text { empresa. }\end{array} \\
\Rightarrow & \begin{array}{l}\text { Avaliar a empresa como } \\
\text { um todo sob o aspecto } \\
\text { produtivo. }\end{array}\end{aligned}$ & 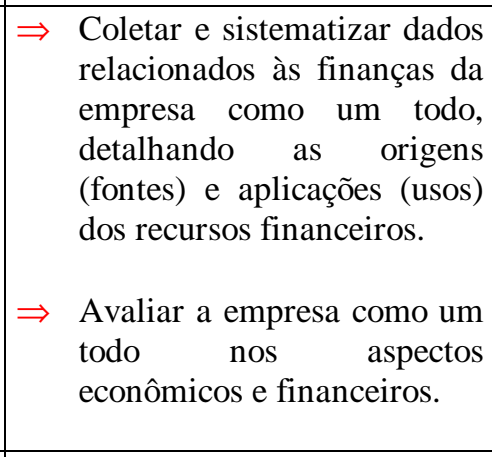 & $\begin{aligned} \Rightarrow & \text { Coletar e sistematizar } \\
& \text { dados relacionados a } \\
& \text { comercialização } \\
& \text { (compras e vendas) da } \\
\text { empresa no médio e } & \\
\text { longo prazo. } & \\
\Rightarrow & \text { Avaliar a empresa } \\
& \text { como um todo no as- } \\
\text { pecto da } & \text { comercialização. }\end{aligned}$ & 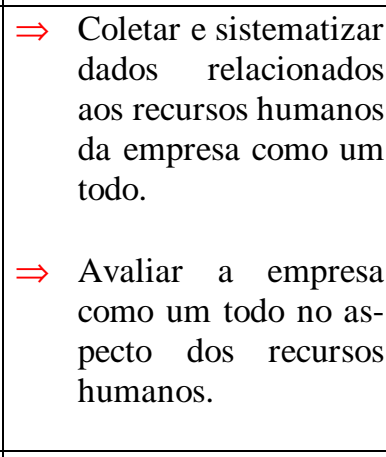 \\
\hline $\begin{array}{c}\text { Controle } \\
\text { operacional }\end{array}$ & 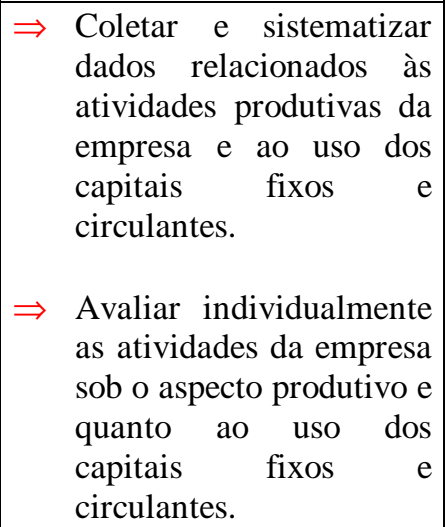 & 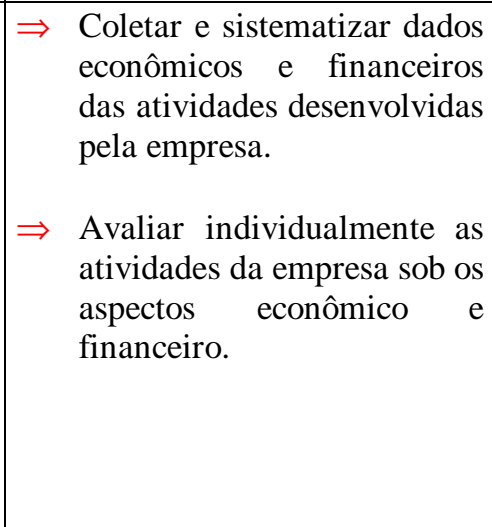 & 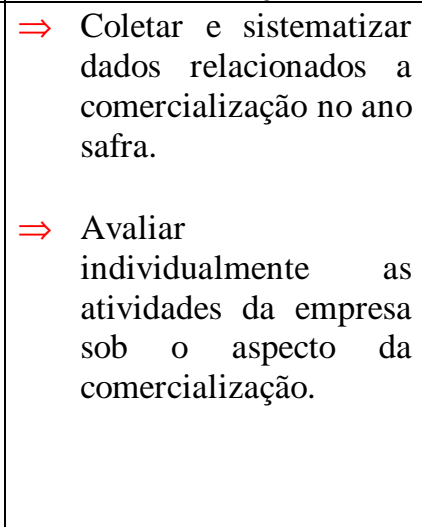 & $\begin{aligned} & \Rightarrow \text { Coletar e sistematizar } \\
& \text { dados relacionados } \\
& \text { aos recursos humanos } \\
& \text { nas atividades da } \\
& \text { empresa. } \\
& \Rightarrow \text { Avaliar as atividades } \\
& \text { da mão-de-obra na } \\
& \text { empresa. }\end{aligned}$ \\
\hline
\end{tabular}


Além de possíveis vantagens para uma melhor compreensão do processo administrativo, no presente estudo a separação das atividades administrativas apresentadas no Quadro 1 tem por objetivo facilitar a apresentação de hipóteses (item 3.2) e servir de base para uma discussão (nos capítulos 5 e 6) sobre os seguintes aspectos: (1) sobre os fatores que limitam o uso da gestão nas empresas agropecuárias, na visão de produtores e técnicos; (2) sobre o grau de relevância, importância ou utilidade de cada uma das atividades administrativas para o sucesso de diferentes empresas agropecuárias; (3) sobre o grau de limitação ou dificuldade dos produtores rurais de implementá-las em nível de campo.

\subsection{Hipóteses sobre a relevância das atividades administrativas}

Considerando que diferentes empresas agropecuárias possuem diferentes formas de administração (valendo-se mais ou menos de determinadas atividades administrativas), é possível se agrupar empresas semelhantes e, assim, poder propor formas alternativas de administração para determinados grupos de empresas. Devem existir, portanto, similaridades na forma de se administrar empresas agropecuárias semelhantes e diferenças significativas na forma de se administrar empresas agropecuárias diferentes. As seguintes variáveis podem ser consideradas para se diferenciar administrativamente as empresas agropecuárias: (1) as atividades econômicas existentes na empresa; (2) as características do mercado na qual a empresa está inserida; (3) a estratégia traçada pela empresa; (4) a idade e a escolaridade do empresário rural; entre outras.

Conforme já especificado anteriormente, pretende-se também com esse trabalho subsidiar os profissionais da assistência técnica a melhor compreenderem o processo administrativo das empresas agropecuárias e, assim, poderem contribuir para a melhoria do processo de aconselhamento econômico e administrativo a produtores rurais comerciais. O procedimento utilizado para a construção dessas novas recomendações 
tomará por base o modelo teórico proposto e será discutido adiante no capítulo 6, após uma melhor compreensão sobre as limitações que restringem o uso das atividades administrativas nas empresas agropecuárias. $\mathrm{Na}$ construção de recomendações administrativas será considerado o estabelecimento de um ambiente no qual a empresa agropecuária está inserida. Isso será feito através da idealização de algumas empresas agropecuárias referenciais, onde, por hipótese, espera-se verificar diferenças significativas no processo administrativo dessas empresas. A seguir, algumas hipóteses gerais sobre a relevância das atividades administrativas serão apresentadas e, certamente, algumas serão válidas ou mais apropriadas para algumas empresas e menos apropriadas para outras empresas, e vice versa. Da mesma forma, espera-se que algumas hipóteses sejam mais bem aceitas por produtores rurais e menos por profissionais da assistência técnica, ou ao contrário.

Dada a nova realidade macroeconômica do setor rural brasileiro, que vem reduzindo a rentabilidade das empresas agropecuárias, espera-se que várias técnicas de gestão passarão a ser mais utilizadas por produtores rurais e profissionais da assistência técnica. Atualmente, embora reconheçam que atuam de forma ineficiente na gestão da propriedade rural, tanto produtores como técnicos, percebem a necessidade de maiores esforços para melhorar o gerenciamento da empresa agropecuária. Dentre as técnicas de gestão, possivelmente serão mais utilizadas aquelas relacionadas ao controle e análise dos resultados econômicos e ao planejamento estratégico da empresa.

O planejamento estratégico, por exemplo, deverá ser mais formal e seu uso mais freqüente na empresa rural. Maior atenção será dada ao processo de tomada de decisão, em substituição à elaboração de planos como um fim em si mesmo. Na área de análise de investimentos maior atenção deverá ser dada à elaboração e análise de projetos de fluxo incremental. Esses projetos são aqueles que interferem em apenas parte dos negócios da fazenda e que representam a grande maioria dos casos envolvendo pequenas decisões de investimentos em empresas agropecuárias, não necessariamente vinculadas à captação de recursos bancários, mas provavelmente realizadas com 
recursos próprios. O risco e incerteza, possivelmente, serão incorporados com maior freqüência à análise de investimentos nas empresas agropecuárias, através de técnicas de "simulação", como por exemplo, aquelas que consideram a "construção" de cenários pessimistas e otimistas em relação às principais variáveis dos projetos.

Com relação ao planejamento estratégico da produção espera-se que ele contemple cada vez mais os sinais do mercado (ambiente externo à empresa), através de suas ameaças e oportunidades, como referência de curto e longo prazo para alterações no sistema de produção. No âmbito financeiro, o planejamento também será mais freqüente, com os produtores passando a fazer "mais contas", antes de tomarem decisões importantes. Por outro lado, espera-se que os avanços no planejamento da área de comercialização e na área de pessoal sejam mais lentos. Na visão dos produtores, a manutenção ou ampliação dos gastos familiares continuarão sendo prioridade, mesmo que isso possa retardar o crescimento da empresa agropecuária. $\mathrm{Na}$ área de recursos humanos, restrições como a baixa qualificação da mão-de-obra rural e a concentração de atribuições administrativas sobre o produtor rural devem manter, ainda por algum tempo, a predominância da forma autocrática de liderança e comunicação na empresa agropecuária. Na área de comercialização, os principais avanços devem estar relacionados, ou à integração produtor/indústria no caso de alguns produtos, ou a vendas de produtos no mercado futuro voltadas a obtenção de créditos para o financiamento da produção no caso de outros produtos.

Na área da controladoria, espera-se maior atenção ao estabelecimento de "benchmarks" (padrões de desempenho) no âmbito interno da empresa agropecuária, ao invés de se trabalhar com dados médios regionais como se fazia no passado. Esses padrões de desempenho servirão como informação auxiliar para o diagnóstico econômico e administrativo das empresas agropecuárias e, para uma conseqüente identificação da necessidade de se realizar intervenções administrativas, a fim de se alterar o sistema de produção. Especificamente, com relação à área de custos de produção, espera-se que maior atenção seja dispensada ao cálculo dos custos totais 
(incluindo os custos fixos, hoje relegados a um segundo plano), como um importante indicador para se verificar a sustentabilidade econômica de médio e longo prazo das empresas agropecuárias.

No controle da empresa agropecuária a informática ganhará cada vez mais espaço. Os softwares existentes no mercado, entretanto, deverão passar por significativas reestruturações de visual e funcionamento, em busca de maior simplicidade e interatividade para o usuário, mesmo que percam recursos ou performance, em termos de sua abrangência ou capacidade de detalhamento. Será dada preferência a softwares que exijam menores esforços na coleta de dados a campo e que gerem resultados de fácil interpretação.

Com relação à organização física e gerencial da produção na empresa agropecuária, espera-se rápida evolução para melhor. O empresário rural não se contentará mais, apenas em conhecer os resultados globais, mas desejará conhecer os resultados individuais de cada atividade de sua empresa. Assim, o plano de contas e os centros de custos serão mais detalhados.

$\mathrm{Na}$ maioria das empresas agropecuárias a direção continuará sendo exercida de forma centralizada pelo produtor rural. Haverá maior preocupação do produtor rural com os aspectos comerciais e financeiros da empresa agropecuária. Quanto à direção operacional da produção, que exige a maior parte do tempo de trabalho do produtor rural, poderá haver uma maior divisão do trabalho através de parcerias ou contratação de pessoal mais qualificado.

A maioria dos profissionais da assistência técnica continuará limitada as tarefas de repassar novas tecnologias e técnicas de produção aos produtores rurais. No entanto, para aqueles profissionais mais qualificados na área de gestão e também mais independentes (como por exemplo, aqueles sem vínculo trabalhista com empresas que 
mantém relações comerciais com os produtores), haverá maior campo de trabalho para atuarem prestando assessoria administrativa aos produtores. 


\section{METODOLOGIA}

Para uma melhor compreensão sobre as principais razões que conduzem os produtores rurais comerciais a pouco utilizarem técnicas de gerenciamento, a pesquisa fez uso principalmente de dados primários, levantados diretamente junto a produtores rurais, profissionais da assistência técnica e outras pessoas com vínculo profissional ao meio agropecuário. A coleta dos dados primários foi feita, inicialmente, mediante entrevistas grupais (grupos focais), e em seguida, após uma melhor compreensão da problemática em estudo, o levantamento dos dados foi complementado com a aplicação de questionários estruturados, com questões fechadas, a fim de transformar uma série de fatos qualitativos (denominados atributos) numa série de valores quantitativos (denominados variáveis) e, assim, permitir a analise estatística dos resultados.

Neste capítulo, apresenta-se a metodologia utilizada na pesquisa de campo, ficando para o capítulo 5 a apresentação e discussão de seus resultados e, para o capítulo 6, a apresentação de sugestões e recomendações para a prática da administração rural. O item 4.1 contempla a parte qualitativa da pesquisa e o item 4.2, a parte quantitativa. Na abordagem qualitativa descreve-se, inicialmente, a técnica de grupos focais, utilizada para a identificação qualitativa das principais dificuldades para a prática do processo administrativo nas empresas agropecuárias, seguida pela identificação da amostra da pesquisa qualitativa. Na abordagem quantitativa descreve-se, inicialmente, a forma como foi estruturado o questionário da pesquisa, a fim de se quantificar (em termos ordinais) a opinião e percepção de produtores, técnicos e outros profissionais 
sobre questões relacionadas à administração da empresa agropecuária, também seguida pela identificação da amostra.

\subsection{Dificuldades no processo administrativo}

\subsubsection{A técnica de grupos focais ${ }^{23}$}

A técnica de pesquisa denominada grupo focal foi a selecionada para a descrição qualitativa sobre a maneira como os produtores rurais comerciais têm conduzido seu processo administrativo e de tomada de decisões e, também, para a identificação das principais dificuldades desses produtores no exercício das funções administrativas no âmbito das empresas agropecuárias. Na fase inicial de investigação, a escolha da técnica metodológica do grupo focal se justifica: (1) pela necessidade de uma maior compreensão dos comportamentos e valores vigentes no meio rural; (2) pela possibilidade de se reunir os diferentes atores num espaço de investigação que pudesse propiciar uma reflexão crítica sobre o cotidiano profissional, vivenciados por produtores e técnicos, possibilitando a observação de pontos consensuais e divergentes.

Grupo focal é uma técnica de pesquisa qualitativa que utiliza sessões grupais, como uma forma facilitadora da expressão de pensamento de um grupo social sobre um tópico específico. A técnica propõe a coleta de dados primários através da observação e análise das discussões em grupo de várias questões relacionadas ao objeto em estudo. Essa técnica pode ser considerada como um tipo especial de entrevista a grupos, que é estruturada para se obter, de participantes selecionados, conhecimentos e opiniões detalhadas sobre um tópico particular. A estruturação do grupo segue alguns

${ }^{23}$ Este item foi baseado nos trabalhos de Chiesa \& Ciampone (1999); Westphal (1996); Carlini-Cotrim (1996) e Bader \& Rossi (1999). 
critérios previamente estabelecidos conforme seu propósito, tamanho, composição e dinâmica.

A técnica do grupo focal permite verificar rapidamente e com certo grau de profundidade vários aspectos sobre um dado problema, tais como: o desenvolvimento do pensar coletivo sobre uma temática que faz parte da vida das pessoas reunidas; o conhecimento sobre o processo de interação entre os participantes; a observação de como as controvérsias se expressam e são resolvidas, reproduzindo processos de interação que ocorrem fora dos encontros grupais. Uma das vantagens da utilização de grupos focais como técnica de pesquisa é a possibilidade de se pensar coletivamente sobre uma temática, tendo em vista a tendência humana de formar opiniões na interação com outro indivíduo. Nas discussões não há necessidade de consenso. Ao contrário, as divergências de perspectivas e experiências são extremamente bem vindas.

A captação e compreensão de fenômenos ligados ao campo social, através de aspectos qualitativos, parte de uma concepção crítica da realidade e da premissa que a realidade só pode ser compreendida através do resgate do vivido. Pressupondo que percepções, atitudes, opiniões e representações são socialmente construídas, a expressão das mesmas seria mais facilmente captada durante um processo de interação em que os comentários de uns podem fazer emergir a opinião dos outros, e em que o ambiente permissivo pode facilitar a expressão de emoções.

Pela observação dos grupos focais é possível conhecer os processos dinâmicos da interação entre os participantes, como as controvérsias vêm à tona e como os problemas são resolvidos. Esses processos são reproduções do que ocorre fora dos grupos e geram resultados e aproximações do problema que incorporam uma dimensão do processo cognitivo que só pode ser obtida em tal situação. Esse procedimento é particularmente apropriado quando o objetivo do investigador é verificar de que modo as pessoas avaliam uma experiência, idéia ou evento, como definem um problema, e como 
suas opiniões, sentimentos e significados encontram-se associados a determinados fenômenos.

Relativamente à utilização de entrevistas semi-estruturadas, a técnica do grupo focal possui a vantagem de se atingir um maior número de pessoas ao mesmo tempo e a possibilidade do aprofundamento das discussões em função da troca que ocorre no grupo. Ademais, a estratégia de grupo focal pode configurar-se: (a) como uma etapa qualitativa precedente a outros estudos de caráter quantitativo; (b) como fonte preliminar de informação para a elaboração e teste de questionários e escalas para projetos de pesquisas quantitativas; (c) como meio para se obter a interpretação de um grupo sobre resultados quantitativos obtidos em estudos prévios; (d) como meio para fornecer um quadro inicial para estudo de um campo específico até então não explorado cientificamente. Como desvantagens da abordagem qualitativa pode-se citar: (i) a possibilidade de existir diferenças de interpretação sobre uma determinada situação, por parte dos sujeitos envolvidos no processo, seja o investigador ou um membro da população em estudo; (ii) a grande dificuldade para a generalização dos resultados; (iii) o fato de a verdade ser sempre relativa ao contexto onde emerge o objeto do conhecimento e aos critérios utilizados para a sua investigação.

A técnica do grupo focal possui as seguintes fases: (1) definição do problema, dos objetivos e do esquema conceitual para o assunto em questão; (2) escolha da equipe de trabalho composta pelo coordenador (ou moderador) e pelo observador (ou assistente); (3) determinação dos critérios para a seleção da amostra; (4) elaboração e teste de um roteiro de questões que o grupo deve discutir; (5) recrutamento dos participantes para o local e horário combinados; (6) sistematização e análise dos diálogos gravados e transcritos.

O coordenador de um grupo focal deve ser alguém treinado para o processo e que atue como um facilitador da interação entre os participantes a fim de propiciar a eles a livre expressão de seus sentimentos, opiniões e pareceres sobre a 
questão em estudo em um processo de discussão focalizada. Deve garantir, através de uma intervenção discreta e firme, que o grupo cubra os tópicos de interesse do estudo de maneira menos diretiva possível. Para tanto deve, quando julgar necessário: solicitar esclarecimentos ou aprofundamentos em pontos específicos; conduzir o grupo para o próximo tópico; estimular os tímidos; desestimular os dominadores; solicitar considerações finais; finalizar a discussão. O observador, por sua vez, deve assumir a tarefa de registrar todos os acontecimentos no campo grupal, incluindo os aspectos não verbais presentes na comunicação dos participantes, desde o início até o final das sessões.

As principais dificuldades operacionais na condução de grupos focais e as respectivas formas de superá-las ou minimizá-las são as seguintes:

(a) possibilidade de desvio do foco da discussão ou dificuldade de entendimento dos participantes quanto aos objetivos da discussão (minimizado com a presença de um moderador experiente);

(b) possibilidade dos grupos focais serem consideravelmente diferentes em suas características (minimizado com o estabelecimento do maior número possível de grupos a fim de se reduzir as idiossincrasias. A repetição visa identificar tendências e padrões na percepção do que se definiu como foco do estudo. É recomendável um mínimo de 4 grupos focais para cada subgrupo homogêneo definido pelo estudo, mas esse número pode se alterar conforme a convergência dos resultados obtidos);

(c) possibilidade de custos $\mathrm{p} /$ se reunir o grupo (minimizado com a ajuda de pessoas interessadas no assunto);

(d) a análise dos dados, subjetivos por natureza, torna-se particularmente complexa e não é possível se estabelecer a freqüência com que determinados comportamentos ou opiniões ocorrem (a interpretação dos dados deve levar em conta o ambiente social do grupo focal e a técnica denominada "análise de conteúdo" pode minimizar esse problema);

(e) utilização de amostra intencional (minimizado quando o grupo focal é utilizado como complemento a estudos descritivos que geram dados quantitativos); 
(f) não há tratamento estatístico, mas sim um conjunto de procedimentos que visam a organizar os dados de modo que eles revelem, com a objetividade e isenção possíveis, como os grupos em questão percebem e se relacionam com o foco do estudo em pauta.

Os participantes de um grupo focal normalmente são escolhidos de forma intencional (amostra intencional). É recomendável que o número de participantes em cada grupo seja de 6 a 10. Os participantes não devem ser familiares uns aos outros (em termos de círculo de amizade ou trabalho), mas devem possuir certas características em comum e que estão associadas ao tópico que está sendo pesquisado. A homogeneidade pretendida deve ser em termos de características pessoais, mas não na percepção do assunto em foco. O objetivo principal do grupo focal é captar o contraste de diferentes perspectivas entre pessoas semelhantes, evitando-se incontornáveis discussões frontais ou recusa sistemática de emitir opiniões. O ambiente de trabalho do grupo focal deve garantir um clima confortável para a troca de experiências e impressões de caráter muitas vezes pessoal. O tempo de cada sessão não deve ultrapassar duas horas e os diálogos devem ser gravados.

A análise dos dados deve, inicialmente, ser realizada de forma independente pelo coordenador e pelo observador, para em seguida serem discutidas em conjunto. Os sumários etnográficos, compostos por citações textuais dos participantes, devem servir de base para a análise do conteúdo. Deve-se proceder à codificação dos dados via descrição numérica de como determinadas categorias explicativas aparecem ou estão ausentes da discussão, e em quais contextos isto ocorre.

Finalmente, com a técnica da análise de discurso procura-se aprender os significados dos textos, articulando-os às condições remotas de sua produção a fim de compreender o que os depoimentos trazem de verdadeiro. A análise de discurso não pretende colocar em cheque a posição ideológica do enunciador real, mas sim entender como o enunciador vê o mundo e, portanto, reconhecer, interpretar e reinterpretar as concepções sobre determinado objeto. $\mathrm{Na}$ análise do discurso busca-se o 
encadeamento/articulação entre os temas abordados, identificando congruências e/ou ambigüidades na fala dos enunciadores. Em seguida, procede-se à recomposição, através de frases temáticas que sintetizam os temas e sub-temas do discurso em sua totalidade. A decodificação dos discursos, sintetizada em frases temáticas, contém qualificativos que permitem o agrupamento dessas frases facilitando a classificação/categorização do material empírico.

\subsubsection{Definição da amostra}

$\mathrm{Na}$ definição dos grupos focais foram selecionados, intencionalmente, produtores e técnicos vinculados a dois importantes ${ }^{24}$ sistemas de produção, representativos do setor agropecuário brasileiro: a produção de grãos e a bovinocultura de corte. Além de sua importância sócio-econômica, a escolha desses dois sistemas de produção se baseou na expectativa de se encontrar diferenças significativas no processo administrativo, conduzido nas propriedades rurais onde predomina a exploração de culturas anuais (grãos) e nas propriedades rurais onde predomina a exploração de pecuária de corte (bovinocultura).

Considerando a necessidade de ter-se 4 grupos focais para cada sub-grupo homogêneo definido no estudo, ao todo foram constituídos 8 grupos focais, sendo 4 compostos por pessoas ligadas à produção de grãos e 4 por pessoas ligadas à bovinocultura de corte. Na maioria dos casos, reuniu-se de forma separada com produtores rurais e profissionais da assistência técnica. $\mathrm{O}$ número médio de participantes, em cada um dos 8 grupos focais, foi de 10 pessoas. As reuniões dos grupos focais ocorreram em várias regiões do Estado do Paraná, entre os meses de junho a setembro de 2000 (tabela 2). 
$\mathrm{Na}$ organização dos grupos focais contou-se com o apoio das seguintes instituições: Associação dos Engenheiros Agrônomos de Campo Mourão (sessões 1 e 2), Sociedade Cooperativa Castrolanda Ltda (sessões 3 e 4), Federação da Agricultura do Estado do Paraná (sessões 5 a 8).

Tabela 2. Atividade principal dos participantes, local e data das reuniões dos grupos focais.

\begin{tabular}{ccccc}
\hline Sessão & Sub-grupo & Participantes $^{(1)}$ & Local & Data \\
\hline 1 & Agricultura & Técnicos p/ agricultura & Campo Mourão - PR & $01 /$ junho/2000 \\
2 & Agricultura & Agricultores & Campo Mourão - PR & $01 /$ junho/2000 \\
3 & Agricultura & Técnicos p/ agricultura & Castro - PR & $09 /$ junho/2000 \\
4 & Agricultura & Agricultores & Castro - PR & $09 /$ junho/2000 \\
5 & Pecuária & Técnicos p/ pecuária & Ibiporã - PR & $02 /$ setembro/2000 \\
6 & Pecuária & Pecuaristas & Ibiporã - PR & $02 /$ setembro/2000 \\
7 & Pecuária & Técnicos p/ pecuária & Assis Chateaubriand - PR & 23/setembro/2000 \\
8 & Pecuária & Pecuaristas & Assis Chateaubriand - PR & 23/setembro/2000 \\
\hline
\end{tabular}

${ }^{1}$ grupo predominante nos grupos focais.

\subsection{Opiniões e percepções sobre a administração da empresa agropecuária.}

A partir dos fatos relevantes observados nos grupos focais, procurou-se quantificar a concordância ou discordância dos resultados obtidos nessas reuniões, junto a uma amostra representativa de produtores rurais comerciais e profissionais da assistência técnica privada. Para tanto, um questionário com 36 afirmações (ou questões) foi aplicado junto ao público alvo, a fim de obter a opinião e percepção ${ }^{25}$ de produtores e

\footnotetext{
${ }^{24}$ A importância socioeconômica da produção de grãos e carne bovina pode ser expressa, por exemplo, pelo valor bruto da produção desses produtos e pelo número de produtores e trabalhadores rurais envolvidos com essas atividades agropecuárias.

25 Aqui, o termo "opinião" se refere ao modo como os produtores e técnicos vêem, pensam e deliberam sobre uma determinada afirmação. A opinião, portanto, envolve a manifestação de um juízo de valor
} 
técnicos sobre algumas questões relacionadas à administração da empresa agropecuária. A íntegra do questionário pode ser visualizada no apêndice 2.

\subsubsection{Estruturação do questionário}

$\mathrm{Na}$ elaboração das afirmações contidas no questionário, procurou-se contemplar as principais dificuldades, relatadas nos grupos focais, para o uso de técnicas de gestão na empresa agropecuária. Considerando o modelo teórico proposto, a formulação das questões levou em consideração a necessidade de se contemplar assuntos relacionados às funções do processo administrativo (planejamento, organização, direção e controle), exercidas nas diferentes áreas de decisão da empresa agropecuária (produção, finanças, comercialização e pessoal).

$\mathrm{Na}$ identificação do entrevistado ${ }^{26}$ solicitou-se que indicasse: (a) sua atividade principal (agricultor, pecuarista, assistência técnica para agricultura, assistência técnica para pecuária ou outra atividade principal $^{27}$ ); (b) a exploração principal com a qual trabalha (produção de grãos, cana-de-açúcar, outras lavouras, bovinocultura de corte, bovinocultura de leite, outras criações); (c) seu grau de escolaridade (até o primeiro grau, segundo grau ou superior); (d) sua idade (até 30 anos,

sobre um determinado assunto. Já o termo "percepção" é mais subjetivo e se refere ao modo como os produtores e técnicos notam ou compreendem um determinado assunto. A percepção, portanto, envolve a manifestação de um sentimento das pessoas sobre o assunto em questão. Com a aplicação do questionário, pretendeu-se obter as duas variáveis (opinião e percepção) simultaneamente através do estabelecimento de notas na escala decimal (de zero a dez), ora utilizando afirmações (frases) pessoais ou diretas, ora valendo-se de afirmações impessoais ou indiretas.

${ }^{26}$ Em função do caráter opinativo do questionário, não foi solicitada a identificação nominal do entrevistado. Além disso, as questões não foram explicadas ao entrevistado a fim de não influenciar sua opinião, ficando a interpretação das afirmações por sua conta. A adoção desse procedimento na pesquisa proporcionou um menor retorno percentual de questionários, enviados pelo correio, a produtores rurais com baixo grau de escolaridade. Essa dificuldade, no entanto, foi minimizada com a entrega "em mãos" dos questionários a esses produtores.

${ }^{27}$ Quando o entrevistado, inadvertidamente, indicou mais de uma atividade principal, ele foi classificado na opção "outra atividade principal", aumentando a participação desse grupo no total da amostra. Na tabulação dos dados, esse critério foi estabelecido para permitir uma efetiva comparação dos resultados obtidos, entre aqueles que efetivamente indicaram apenas a sua atividade principal, dentre as seguintes opções listadas: agricultores, pecuaristas, técnicos para a agricultura ou técnicos para a pecuária. 
de 31 a 40 anos, de 41 a 50 anos ou mais de 51 anos); e (e) o principal município onde trabalha.

Para a mensuração do grau de concordância dos entrevistados, sobre as afirmações contidas no questionário, foi adotada a escala decimal de zero a dez. A opção pela escala decimal no questionário, levou em consideração sua maior facilidade de compreensão no meio rural, tendo em vista seu freqüente uso no sistema educacional brasileiro. Na escala considerada, as notas atribuídas pelos entrevistados às afirmações possuem o seguinte significado: a nota zero significa total discordância; notas de um a quatro significam discordância parcial; nota cinco significa indiferença; notas de seis a nove significam concordância parcial e a nota dez significa total concordância. No questionário uma seta em direção a nota zero indicava maior discordância e uma seta em direção a nota dez indicava maior concordância (apêndice 2).

No questionário ${ }^{28}$, as quatro primeiras afirmações são gerais ou introdutórias, a fim de despertar o interesse do entrevistado pelo questionário e direcionar sua atenção para questões administrativas da empresa agropecuária. São elas: (1) "Na última década, os gastos para a manutenção da família têm crescido a uma velocidade maior do que o aumento de receita líquida da propriedade rural". (2) "Promover um bom padrão de vida para a família é o principal objetivo da propriedade rural". (3) "O resultado econômico/financeiro das atividades agropecuárias é afetado, muito mais por variações do clima e dos preços agrícolas, do que por problemas administrativos internos da propriedade rural". (4) "No atendimento ao produtor, a assistência técnica concentra seu trabalho na orientação da produção e atua pouco em questões administrativas das propriedades rurais".

\footnotetext{
${ }^{28} \mathrm{Na}$ formulação do questionário buscou-se uma correspondência das afirmações com algumas atividades administrativas das empresas agropecuárias, embora se reconheça que essa correspondência não é única e exata. Pela ordem, nas 36 afirmações do questionário, buscou-se as seguintes correspondências: 4 são gerais; 8 relacionam-se à atividades administrativas de planejamento; 8 relacionam-se à organização; 8 à direção e 8 ao controle.
} 
As afirmações de número 5 a 12 relacionam-se ao planejamento das diferentes áreas empresarias da propriedade rural, ou seja, relacionam-se ao planejamento da produção, das finanças, da comercialização e ao planejamento do pessoal. São elas: (5) "A necessidade de usar a infraestrutura existente na propriedade e a incerteza quanto aos preços futuros (que podem ser altos ou baixos) estimula o produtor rural a manter sua produção, de acordo com o seu planejamento de longo prazo". (6) "É preferível fazer o planejamento da propriedade mentalmente e não por escrito, pois são constantes as mudanças na política econômica, no clima e nos preços. $\mathrm{O}$ planejamento mental é mais versátil do que o planejamento escrito". (7) "Se o produtor rural começar a fazer muitas contas no papel e verificar os prováveis resultados, ele poderia perder o estímulo de produzir". (8-) "A necessidade de caixa (dinheiro) para pagar compromissos financeiros, normalmente é o que determina o momento da venda da produção". (9) "Os produtores rurais preferem trabalhar as suas atividades com maior estoque patrimonial (terras, máquinas, animais) do que com maior liquidez no caixa (disponibilidade financeira). Por isso, em anos de sobra de caixa, preferem investir na propriedade do que guardar o dinheiro no banco". (10) A principal dificuldade para se planejar a compra de insumos é a falta de recursos financeiros na propriedade em determinadas épocas do ano. (11) "A legislação trabalhista é mais adaptada ao meio urbano. Por isso, em propriedades rurais, é mais difícil cumpri-la integralmente”. (12) "As propriedades rurais normalmente trabalham com ociosidade de mão-de-obra fixa, pois na média anual, o número de empregados fixos é determinado em função dos períodos de maior necessidade de trabalho".

Da mesma forma, as afirmações de números 13 a 20 relacionam-se a organização das áreas de produção, finanças comercialização e pessoal. São elas: (13) “O produtor rural tem uma maior preocupação com os aspectos de produção (tecnologia) do que pelos aspectos administrativos de sua propriedade". (14-) “As propriedades rurais normalmente trabalham com infraestrutura ociosa (máquinas, equipamentos, etc.), pois na média anual, o tamanho dessa infraestrutura é determinado em função da possibilidade de ocorrer períodos críticos (adversidades climáticas, etc)". (15) "Na 
avaliação da propriedade, o mais importante é conhecer os resultados globais, pois as diferenças de resultados entre talhões/lotes geralmente se devem a questões climáticas ou a outras variáveis que não podem ser controladas pelo produtor". (16) "O produtor rural tem dificuldade para entender e utilizar os softwares (programas de computador) desenvolvidos para o meio rural". (17) "O produtor rural recebe constantemente informações de muitas pessoas e instituições e de várias formas (até via TV). Isso dificulta a escolha do melhor produto (insumo) comercial a ser utilizado na propriedade". (18) "Há uma grande pressão das empresas e/ou cooperativas sobre o produtor rural para que ele seja fiel na entrega de sua produção". (19) "O produtor rural não tem tempo para fazer planejamento por escrito e manter controles pormenorizados. É uma correria todo dia, para executar os serviços e tarefas operacionais que exigem atenção permanente". (20) "Como o produtor tem que gastar a maior parte do seu tempo cuidando da produção, sobra a ele pouco tempo para analisar as áreas financeira e comercial da empresa rural".

Na sequiência, as afirmações de números 21 a 28 relacionam-se a direção das áreas de produção, finanças, comercialização e pessoal. São elas: (21) "Os bons produtores rurais são aqueles que obtém alta produtividade". (22) "Primeiro é preciso melhorar a tecnologia para aumentar a produtividade, depois se preocupar com planos e controles para a propriedade. (23). "A grande maioria dos produtores rurais não separa em seus registros os gastos da família e os gastos da propriedade". (24) "Alguns dados financeiros da propriedade (como o valor dos gastos familiares, o valor de dívidas, etc.) não são assunto para serem tratados com profissionais da assistência técnica. (25) "O envolvimento dos profissionais da assistência técnica com a venda de insumos inibe os produtores rurais, de receber deles, assessoria administrativa na propriedade". (26) "Comprar e vender é tarefa do produtor rural. Raramente (à exceção das transações de pequenos valores) ela é delegada a funcionários da fazenda". (27) "No meio agropecuário não adianta muito querer controlar tudo por escrito. O importante é o responsável estar presente na propriedade, pois assim já estaria efetuando os controles de forma visual, mas permanente". (28) "No meio agropecuário, as ordens de serviço que 
os produtores repassam aos funcionários devem ser bem claras e diretas, pois não adianta muito ficar trocando idéias com os funcionários".

Por fim, as afirmações de números 29 a 36 relacionam-se ao controle da produção, das finanças, da comercialização e do pessoal. São elas: (29) "Se o profissional da assistência técnica prestar ao produtor uma boa orientação tecnológica, isso já é uma grande contribuição para a propriedade, pois questões administrativas são responsabilidade do produtor rural". (30) "As propriedades rurais, geralmente não adotam sistemas detalhados de controle de custos pela grande dificuldade de se coletar dados precisos (ou exatos) em nível de campo". (31) "Alguns poucos indicadores de eficiência (produtividade, índices zootécnicos, etc.) e de resultado (sobra de dinheiro em caixa, etc.) são suficientes para indicar se a propriedade está indo bem ou mal”. (32) "As propriedades rurais, geralmente não adotam sistemas detalhados de controle porque esse trabalho não garante um aumento na rentabilidade". (33) "É possível que um sistema de controle simplificado seja suficiente para garantir uma boa administração da propriedade rural, porque eles permitem, pelo menos, uma noção sobre os resultados técnicos e econômicos do empreendimento". (34) "Na compra dos insumos e na venda da produção, o mais importante é controlar as quantidades para evitar desvios, pois os preços são definidos pelo mercado". (35) “Os funcionários das propriedades rurais não gostam de fazer anotações por escrito sobre as tarefas realizadas". (36) "Os funcionários das propriedades rurais não sabem ou têm muitas dificuldades para fazer anotações por escrito sobre as tarefas realizadas".

\subsubsection{Definição da amostra}

Com o objetivo de obter o maior número possível de questionários preenchidos, atendendo as restrições orçamentárias e de tempo e complexidade da pesquisa, várias estratégias para a aplicação dos questionários foram utilizadas, dentre as quais destacam-se: (a) contato pessoal com os entrevistados (produtores rurais e 
profissionais da assistência técnica), solicitando que eles respondessem o questionário; (b) envio do questionário pelo correio, indicando formas alternativas para a sua devolução; (c) entrega pessoal ou envio do questionário (por correio e por e-mail) a determinadas pessoas chaves (colaboradores), com a solicitação de que elas redirecionassem o questionário a outras pessoas pertencentes ao público alvo da pesquisa. Tendo em vista a adoção dessas estratégias, não é possível uma identificação exata do número de questionários aplicados, mas estima-se que esse número seja um pouco superior a três mil unidades.

Especificamente, os seguintes esforços para a distribuição do questionário ao maior número possível de produtores rurais e profissionais da assistência técnica foram realizados: (1) envio do questionário pelo correio a dois mil produtores rurais cadastrados $^{29}$ no banco de dados da Federação da Agricultura do Estado do Paraná (FAEP). Esses dois mil produtores rurais foram escolhidos aleatoriamente (sorteados), tendo em vista a disponibilidade de um número bem maior de produtores rurais (pessoas físicas) no cadastro da FAEP; (2) envio de trezentas cópias do questionário a cerca de trinta profissionais dos departamentos técnicos das cooperativas agropecuárias do Estado do Paraná, com a solicitação de que, cada um deles, respondesse o questionário e também o redirecionasse para que fosse respondido por outros técnicos da cooperativa e por produtores rurais a ela associados; (3) envio de quinhentas cópias do questionário a cerca de cinqüenta instrutores que realizam treinamentos para o Serviço Nacional de Aprendizagem Rural do Estado do Paraná (SENAR/PR), com a solicitação de que, cada um deles, disponibilizasse os questionários para que fosse respondido por produtores rurais; (4) envio de aproximadamente cem questionários diretamente para técnicos e produtores rurais nos Estados de São Paulo e Mato Grosso do Sul, com a solicitação para que eles: respondessem o questionário e, também, o redirecionassem a outros profissionais e produtores rurais com os quais tivessem vínculo profissional ou de

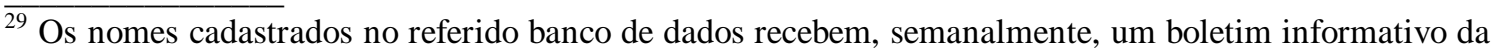
FAEP. Do total de nomes cadastrados, que superam sete mil destinatários, segundo informações da entidade, foram selecionados para o sorteio apenas os produtores rurais (pessoas físicas), que totalizavam aproximadamente cinco mil nomes.
} 
amizade; (5) envio de aproximadamente trinta questionários para técnicos vinculados ao setor sucroalcooleiro dos Estados do Paraná e São Paulo; (6) envio, por e-mail, de aproximadamente trinta questionários para produtores rurais do Estado do Mato Grosso, cadastrados no banco de dados do Centro de Estudo e Pesquisa em Economia Aplicada (CEPEA); (7) aplicação de aproximadamente trinta questionários em reuniões de pecuaristas promovidas pela FAEP; (8) aplicação de trinta e sete questionários junto a diretores, gerentes e técnicos do Banco do Brasil, vinculados ao agronegócio e inscritos no Curso "MBA/ESALQ em Agronegócio"; (8) aplicação de aproximadamente cinqüenta questionários junto a produtores rurais e profissionais da assistência técnica nos Estados de São Paulo, Paraná e Mato Grosso do Sul. Assim, sob o ponto de vista estatístico, pode-se afirmar que a maior parte da amostra foi definida intencionalmente, a fim de representar, preferencialmente, a população composta por produtores rurais comerciais (de grãos e de bovino de corte) e por profissionais da assistência técnica privada que trabalham com essas atividades. A preferência por esse público alvo na pesquisa quantitativa justifica-se pela sua pretensão em buscar uma correspondência dos resultados quantitativos com os resultados qualitativos do grupo focal, composto pelo mesmo público alvo.

Quanto à forma escolhida para a distribuição do questionário levou-se em consideração o caráter opinativo do mesmo, onde o entrevistado, preferencialmente, deve possuir uma disposição pessoal e espontânea em respondê-lo, a fim de que expresse verdadeiramente sua opinião. Neste sentido, ao invés de entrevistas formais (com a presença de entrevistador e entrevistado) preferiu-se a distribuição do questionário, com a orientação de que o próprio entrevistado o interpretasse e o respondesse.

A amostra obtida totalizou 494 questionários, um número suficiente em pesquisas de natureza opinativa, mesmo quando o tamanho exato da população não pode ser determinado. Com a amostra obtida, pode-se afirmar também que se obteve uma boa representatividade e convergência dos resultados, uma vez que análises preliminares 
(com amostras menores) originaram resultados muito semelhantes ao obtido no final da pesquisa.

A tabela 3 discrimina o número de entrevistados que responderam ao questionário e a participação no total da amostra segundo a indicação da atividade principal, dentre as seguintes alternativas apontadas no início do questionário: agricultor, pecuarista, assistência técnica para agricultura, assistência técnica para pecuária, e outra atividade $^{30}$. Do total de 494 entrevistados, 159 indicaram que sua atividade principal era agricultor, 82 indicaram pecuarista, 54 indicaram assistência técnica para a agricultura, 39 indicaram assistência técnica para a pecuária e 160 indicaram a opção outra atividade ou assinalaram mais de uma alternativa.

Tabela 3. Atividade principal das pessoas entrevistadas.

\begin{tabular}{lcc}
\hline Atividade principal do entrevistado & Número de entrevistados & $\%$ \\
\hline Agricultor & 159 & 32,2 \\
Pecuarista & 82 & 16,6 \\
Assistência técnica p/ agricultura & 54 & 10,9 \\
Assistência técnica p/ pecuária & 39 & 7,9 \\
Outra atividade $^{1}$ & 160 & 32,4 \\
\hline Total da amostra & 494 & 100,0 \\
\hline
\end{tabular}

\footnotetext{
${ }^{1}$ Neste item estão inclusos: (a) os entrevistados que indicaram mais de uma atividade principal: agricultor e pecuarista (36), técnico e produtor rural (11), técnico para agricultura e pecuária (4); (b) os entrevistados que indicaram a opção outra atividade e a especificaram: instituição financeira (37), suinocultor (10), ensino ou treinamento (8), gerente comercial (3), gerente de cooperativa (7); (c) os entrevistados que

${ }^{30}$ Quando o entrevistado assinalou a opção "outra atividade" sua classificação foi mantida nesse grupo, mesmo que a exploração principal indicada na questão seguinte permitisse uma reclassificação do mesmo em outra categoria de atividade principal. É o caso, por exemplo, de 10 suinocultores que assinalaram a opção "outra atividade", indicando a suinocultura como atividade principal, mas que não foram reclassificados para a opção "pecuarista".
} 
indicaram a opção outra atividade e não a especificaram (34) e (d) os entrevistados que não informaram sua atividade principal (10).

Os 159 agricultores da amostra indicaram a seguinte exploração principal com a qual trabalham: 112 indicaram que a sua exploração principal era a produção de grãos (soja, milho, trigo, etc), 9 indicaram a cana-de-açúcar e 38 indicaram outras lavouras ou assinalaram mais de uma exploração principal $^{31}$. No caso dos 82 pecuaristas, 60 indicaram que a sua exploração principal era a bovinocultura de corte, 9 indicaram a bovinocultura de leite e 22 indicaram outras criações ou assinalaram mais de uma exploração principal. Já os 54 técnicos que prestam assistência para a agricultura, 37 indicaram a produção de grãos como a exploração principal com a qual trabalham, 5 indicaram a cana-de-açúcar e 12 indicaram outras lavouras ou assinalaram mais de uma exploração principal. Por fim, os 39 técnicos que prestam assistência para a pecuária, 18 indicaram a bovinocultura de corte como a exploração principal com a qual trabalham, 8 indicaram a bovinocultura de leite e 13 indicaram outras criações ou assinalaram mais de uma exploração principal. A amostra, portanto, contempla cinco grupos (ou classes) bem distintos segundo a atividade principal e que servirão de base para a análise dos resultados. São eles: agricultores (principalmente produtores de grãos); pecuaristas (principalmente criadores de bovinos); técnicos para a agricultura (que assistem principalmente produtores de grãos); técnicos para a pecuária (que assistem principalmente criadores de bovino de corte) e os demais entrevistados (que por representarem um grupo bem variado de pessoas terá sua atividade principal indicada com o termo "outra atividade").

A tabela 4 discrimina a faixa de idade dos entrevistados para cada uma das classes de atividade principal. Do total de 494 entrevistados, 100 pertencem à faixa

\footnotetext{
${ }^{31}$ Apesar do texto no questionário solicitar que o entrevistado indicasse apenas a exploração principal com a qual trabalha, muitos entrevistados indicaram as diversas culturas e criações com a qual trabalham, procurando talvez demonstrar a abrangência de seu trabalho. Essa atitude de muitos entrevistados, de indicar mais de uma exploração principal, justificou a retirada dessa variável (exploração principal) da análise estatística dos resultados.
} 
etária até 30 anos, 147 à faixa etária de 31 a 40 anos, 124 à faixa etária de 41 a 50 anos, 112 à faixa etária de mais de 51 anos e 11 entrevistados não indicaram a faixa etária.

Tabela 4: Faixa etária das pessoas entrevistadas segundo a atividade principal.

\begin{tabular}{lccccc}
\hline \multicolumn{1}{c}{ Atividade principal } & $\begin{array}{c}\text { Até 30 } \\
\text { anos }\end{array}$ & $\begin{array}{c}\text { De 31 a 40 } \\
\text { anos }\end{array}$ & $\begin{array}{c}\text { De 41 a 50 } \\
\text { anos }\end{array}$ & $\begin{array}{c}\text { Mais de 50 } \\
\text { anos }\end{array}$ & $\begin{array}{c}\text { Não } \\
\text { informou }\end{array}$ \\
\hline Agricultor & 21 & 43 & 52 & 43 & 0 \\
Pecuarista & 10 & 16 & 18 & 38 & 0 \\
Assistência técnica p/ agricultura & 20 & 25 & 8 & 1 & 0 \\
Assistência técnica p/ pecuária & 14 & 12 & 11 & 2 & 0 \\
Outra atividade & 35 & 51 & 35 & 28 & 11 \\
\hline Total da amostra & 100 & 147 & 124 & 112 & 11 \\
\hline
\end{tabular}

A tabela 5 discrimina o grau de escolaridade dos entrevistados para cada uma das classes de atividade principal. Do total de 494 entrevistados, 58 possuem até o primeiro grau de escolaridade, 109 possuem o segundo grau (completo ou incompleto), 312 possuem grau superior de escolaridade (completo ou incompleto) e 15 não informaram o grau de escolaridade. No aspecto da escolaridade dos entrevistados, cabe ressaltar, que pela relativa complexidade e extensão do questionário, já se esperava um menor retorno de questionários de produtores rurais com menor grau de escolaridade. Entretanto, se de um lado, há essa limitação da pesquisa quanto à composição da amostra obtida, de outro, ela favorece, através de uma menor diferença de escolaridade entre produtores e técnicos, a comparação dos resultados entre os dois grupos. 
Tabela 5. Grau de escolaridade das pessoas entrevistadas segundo a atividade principal.

\begin{tabular}{lcccc}
\hline \multicolumn{1}{c}{ Atividade principal } & Até primeiro grau & Segundo grau & Superior & Não informou \\
\hline Agricultor & 28 & 47 & 81 & 3 \\
Pecuarista & 23 & 16 & 40 & 3 \\
Assistência técnica p/ agricultura & 0 & 5 & 48 & 1 \\
Assistência técnica p/ pecuária & 0 & 4 & 35 & 0 \\
Outra atividade & 7 & 37 & 108 & 8 \\
\hline Total da amostra & 58 & 109 & 312 & 15 \\
\hline
\end{tabular}

A tabela 6 identifica os Estados da federação onde trabalham os entrevistados, para cada uma das classes de atividade principal. Do total de 494 entrevistados, 366 trabalham principalmente no Estado do Paraná, 47 no Estado de São Paulo, 33 no Estado do Mato Grosso do Sul, 38 em outros Estados do país e 10 não indicaram o principal Estado onde trabalham.

Tabela 6. Estado da federação onde trabalham as pessoas entrevistadas segundo a atividade principal.

\begin{tabular}{lccccc}
\hline \multicolumn{1}{c}{ Atividade principal } & PR & SP & MS & $\begin{array}{c}\text { Outros } \\
\text { Estados }^{1}\end{array}$ & $\begin{array}{c}\text { Não } \\
\text { informou }\end{array}$ \\
\hline Agricultor & 125 & 17 & 10 & 5 & 2 \\
Pecuarista & 71 & 2 & 6 & 2 & 1 \\
Assistência técnica p/ agricultura & 46 & 6 & 1 & 0 & 1 \\
Assistência técnica p/ pecuária & 20 & 7 & 9 & 2 & 1 \\
Outra atividade & 104 & 15 & 7 & 29 & 5 \\
\hline Total da amostra & 366 & 47 & 33 & $38\left(^{*}\right)$ & 10 \\
\hline
\end{tabular}

${ }^{1}$ Outros Estados: DF (13), MT (6), MG (4), RJ (4), RS (3), SC (2), RO (1), BA (1), AM (1), GO (1), TO (1), PA (1). 


\subsubsection{Análise estatística ${ }^{32}$}

$\mathrm{Na}$ análise estatística, a mediana é utilizada para representar a tendência central dos dados coletados. A opção pela mediana se deve à natureza ordinal ${ }^{33}$ considerada nesse estudo, das notas atribuídas pelos entrevistados a cada uma das afirmações do questionário. $\mathrm{O}$ valor da mediana para as diferentes afirmações do questionário permite identificar: (1) a concordância ou discordância da maioria ${ }^{34}$ dos entrevistados com a assertiva de cada questão; (2) o grau de concordância ou discordância da maioria dos entrevistados, segundo a escala de 0 a 10 adotada no questionário. Em função do objetivo do estudo, de comparar as diferenças de percepções e opiniões entre os produtores e os profissionais da assistência técnica, a análise estatística dos dados é feita considerando a atividade principal indicada pelos entrevistados, quais sejam: agricultores, pecuaristas, técnicos para agricultura, técnicos para pecuária e outras atividades.

O teste da mediana é utilizado para identificar se existem diferenças na percepção dos entrevistados com relação às afirmações do questionário. Nesse caso, a hipótese da nulidade $\left(\mathrm{H}_{0}\right)$ é de que não há indícios de diferenças (entre as médias verdadeiras da população) de concordância com as afirmações do questionário, segundo as diferentes atividades principais dos entrevistados. A hipótese alternativa $\left(\mathrm{H}_{\mathrm{a}}\right)$ é de que há indícios de diferenças de concordância com as afirmações do questionário segundo as diferentes atividades principais dos entrevistados. O nível de significância adotado é de

\footnotetext{
${ }^{32}$ Os procedimentos estatísticos relacionados nesta secção não serão aqui descritos, pois são amplamente conhecidos e podem ser facilmente encontrados em livros textos de estatística. No trabalho, o processamento dos dados foi realizado com o software SAS (Statistical Analysis System).

${ }^{33}$ Em uma escala de medida ordinal os números são utilizados somente para classificar os elementos, numa ordem crescente ou decrescente. A adoção de escalas ordinais exige que o tratamento dos dados seja feito apenas por testes não-paramétricos.

${ }^{34}$ A mediana: (1) tem acima e abaixo de si o mesmo número de elementos de uma distribuição de freqüência; (2) indica o valor situado exatamente no meio da distribuição; (3) não é afetada por valores extremamente altos ou extremamente baixos. Neste estudo, isso significa que uma mediana de valor 7 , em uma dada questão, indica que a maioria dos entrevistados concorda com a assertiva, pois se sabe que metade dos entrevistados atribuiu nota igual ou superior a sete e a outra metade nota igual ou inferior a sete.
} 
$5 \%$, o que pode ser considerado suficientemente rigoroso para diferenciar a percepção e opinião dos entrevistados com relação às afirmações contidas no questionário.

O teste do qui-quadrado de razão de verossimilhança (teste $\mathrm{G}^{2}$ ) é utilizado para identificar a existência de associação da atividade principal dos entrevistados com relação às afirmações do questionário. Nesse caso, a hipótese da nulidade $\left(\mathrm{H}_{0}\right)$ é de que não há associação entre a atividade principal do entrevistado e a concordância dos entrevistados com as afirmações do questionário. A hipótese alternativa $\left(\mathrm{H}_{\mathrm{a}}\right)$ é de que há associação entre atividade principal e concordância dos entrevistados com as afirmações do questionário. O nível de significância adotado no teste $\mathrm{G}^{2}$ também foi de $5 \%$. 


\section{RESULTADOS E DISCUSSÃO}

\subsection{Resultados qualitativos: a competência no processo administrativo}

Em termos qualitativos, os resultados obtidos nos grupos focais corroboram positivamente as afirmações ou hipóteses relacionadas nas considerações iniciais e na justificativa do estudo (itens 1.1 e 1.3, respectivamente). Com isso, parte do objetivo geral da pesquisa foi atingido, principalmente no que concerne a uma identificação preliminar das principais razões que levam à baixa adoção de técnicas de gestão nas propriedades rurais. Da mesma forma, obteve-se parcialmente uma melhor compreensão sobre a problemática em estudo, o que permitiu uma melhor estruturação do questionário, apresentado no item 4.2.

A técnica de pesquisa do grupo focal foi conduzida seguindo-se as etapas descritas no item 4.1.1 e os depoimentos coletados (dados primários) foram analisados valendo-se das técnicas de análise de discurso e de conteúdo. Inicialmente, os sumários etnográficos serviram de base para a análise do conteúdo das discussões emanadas dos grupos focais. Em seguida, com a técnica da análise de discurso procurou-se interpretar os significados dos textos, à luz do assunto em foco.

Para a apresentação e discussão dos resultados dos grupos focais, buscouse uma correspondência com os temas e sub-temas abordados anteriormente no item 1.3 (p.8-10). Naquele item, vale lembrar, se listou algumas hipóteses ou considerações sobre os principais fatores limitantes à competência administrativa nas propriedades rurais, através das seguintes variáveis: a insuficiência de conhecimento, a falta de habilidades e 
a atitude negativa. Ao longo da discussão dos resultados, alguns depoimentos de técnicos e produtores rurais foram também transcritos, com o intuito de complementar a análise dos dados. Evidentemente, não há uma correspondência exata entre eles, mas a transcrição de alguns depoimentos contribuiu para a formação de um entendimento inicial acerca de algumas variáveis qualitativas presentes no estudo. No apêndice 01, por sua vez, transcreve-se o sumário etnográfico dos depoimentos coletados dos técnicos e produtores rurais nos quatro primeiros grupos focais, de acordo com a ordem cronológica das discussões que ocorreram durante as reuniões.

\subsubsection{Conhecimento}

A insuficiência de conhecimento em administração rural foi amplamente reconhecida, em todos os grupos focais realizados, tanto pelos produtores como pelos técnicos que participaram das discussões. A limitação do conhecimento do produtor ${ }^{35}$ em administração rural foi relacionada nos depoimentos, principalmente, ao baixo nível de educação formal dos produtores e à concentração de sua experiência acumulada e preferência pessoal na área de tecnologias de produção. Nessa direção surgiram alguns depoimentos, tais como: "o nível médio de escolaridade dos produtores brasileiros é de aproximadamente quatro anos"; "a idade do produtor dificulta mudanças, ele não foi educado para isso"; "o produtor rural tem um gosto maior pelos aspectos da produção"; “a visão do caixa e do recurso humano são bem mais desenvolvidas quando as pessoas

\footnotetext{
$\overline{35}$ Segundo pesquisa da Associação Brasileira de Marketing Rural (ABMR), junto a 2.050 produtores rurais da região centro-sul do país, o grau de instrução dos produtores no ano safra 98/99 era o seguinte: $17 \%$ eram analfabetos ou tinham o primário incompleto; $38 \%$ tinham o primário completo e o ginásio incompleto; $14 \%$ tinham o ginásio completo e o colégio incompleto; $19 \%$ tinham o colégio completo e o curso superior incompleto e $13 \%$ tinham o curso superior completo. Com relação a faixa etária dos produtores a pesquisa da ABMR apresenta a seguinte distribuição: $1 \%$ com menos de 20 anos; $12 \%$ entre 21 e 30 anos; $27 \%$ entre 31 a 40 anos; $26 \%$ entre 41 e 50 anos e $34 \%$ com mais de 50 anos.Outros dados relevantes para a presente pesquisa foram os seguintes: (a) os produtores, quando solicitados à indicar qual seria sua avaliação, sobre a credibilidade das instituições financeiras e empresas de assistência técnica no planejamento integral de suas propriedades, responderam: excelente/boa (37\%), regular (36\%) e ruim/péssima (25\%); (b) os produtores, quando solicitados a indicar seu nível de aceitação com relação a hipótese de instituições financeiras e empresas de assistência técnica utilizarem
} 
têm experiência fora da agricultura". Com relação à limitação dos técnicos, vários depoimentos também indicam insuficiência de conhecimento na área de gestão de propriedades rurais. Em síntese, os depoimentos revelam deficiências na formação universitária e carência de experiência prática devido ao modelo de assistência técnica predominante no país. Nessa direção, pode-se citar os seguintes depoimentos: "o currículo de agronomia é muito vasto. A fitotecnia é privilegiada e a área de gestão é deficiente"; "o agrônomo é deficiente na área de gestão e forte na área técnica"; "as escolas formam mais um extensionista do que um consultor"; "nosso trabalho se restringe a acompanhar o desenvolvimento da cultura, do plantio a colheita"; "o conhecimento do técnico é baixo na área administrativa"; "os agrônomos precisam buscar aperfeiçoamento em gestão".

\subsubsection{Habilidades}

Os resultados da pesquisa qualitativa apontam para a existência de várias restrições de ordem técnica e humana que dificultam ou impedem um maior uso de técnicas de gestão nas propriedades rurais. Uma das mais citadas nos depoimentos é a dificuldade de coleta de dados a campo, que restringe a implantação de alguns sistemas formais de controle, principalmente devido à carência de funcionários habilitados para a tarefa. Nessa direção, os seguintes depoimentos podem ser citados: “o cálculo do custo é importante. A principal dificuldade é a coleta de dados"; "a assistência técnica não está preparada para esse trabalho. Falta tempo para os técnicos devido ao modelo atual de assistência"; "o controle é difícil de fazer e precisa de uma retaguarda (pessoal treinado) na propriedade"; "é difícil medir o resultado, pois a agricultura é uma sequiência de cultivos e você não pode analisar as coisas individualmente. Isso desmotiva ações para o controle"; "os resultados do processo de controle demoram muito para aparecer"; "o

suas propriedades em projetos pilotos para ajudar no planejamento integral, responderam: concordam $(67 \%)$; discordam (18\%); nem discordam nem concordam (13\%) e não sabem (2\%). 
rateio dos custos fixos é difícil de fazer"; “”software” rurais existem. O gargalo é coletar dados, devido à predominância de funcionários desqualificados".

A má organização da estrutura de pessoal nas propriedades rurais, com conseqüente acúmulo de responsabilidades para o produtor e alguns funcionários, também surgem em alguns depoimentos, tais como: "o produtor não tem tempo para fazer planejamento. É uma correria todo dia"; "os pequenos produtores se envolvem com trabalhos operacionais manuais e, assim, não tem tempo para a parte administrativa"; "quando anotam não sabem analisar os dados".

A má organização ou até inexistência de um plano de contas gerencial nas propriedades rurais foi confirmado pelos depoimentos. Além da dificuldade para a análise econômica individual das diferentes atividades da propriedade, a falta de um adequado plano de contas gerencial também impede a necessária separação dos gastos familiares e da empresa. Nessa direção surgem alguns depoimentos, tais como: "o produtor mistura o caixa da propriedade com o caixa da família. Isso dificulta a visualização de resultados"; "outra dificuldade é a falta de um padrão de análise. Por exemplo, alguns consideram a seqüência de cultivos. Outros rateiam o custo fixo em 2/3 para o verão e 1/3 para o inverno, etc. Não há uma padronização. Se tiver programa de rotação de culturas dificulta ainda mais"; "na empresa urbana há um padrão de contabilidade. No meio rural não. A análise final é muito demorada e complicada. A rotação de culturas dificulta a análise. A contabilidade rural é voluntária, por isso ela é bagunçada"; "é preciso conter os gastos familiares, que hoje exigem mais do que a propriedade rende".

O maior custo dos serviços de uma assistência agropecuária mais abrangente, que incluam, além da parte tecnológica, outras questões contábeis, econômicas e administrativas, foi, em parte contemplado em alguns depoimentos, tais como: "outro problema é o custo mais elevado da assistência mais abrangente". De outra forma, esse assunto também foi abordado, atribuindo-se às empresas que prestam 
serviços de assistência técnica a definição de um modelo de trabalho centrado apenas em recomendações tecnológicas. Alguns depoimentos apontam nessa direção, tais como: "para o agrônomo a dificuldade de aprender técnicas de gestão não é grande. $\mathrm{O}$ agrônomo, no entanto, tem que seguir a política da empresa onde trabalha e, as empresas seguem um modelo de assistência que não dão tempo ao técnico para trabalhar com gestão".

Por fim, o alto custo para se modificar, no curto e médio prazo, a estrutura vigente nas propriedades rurais, gerando uma certa inércia ou repetição de suas estratégias ao longo do tempo aparece de forma indireta em alguns depoimentos, tais como: "a missão do produtor é produzir. Sempre. Apesar de todas as dificuldades. Na Europa, mesmo em épocas de guerras, o produtor continuava lavrando e cultivando suas terras".

\subsubsection{Atitudes}

A existência de atitudes negativas, em função de hábitos, costumes, crenças e valores vigentes também foi apontada, nos depoimentos, como justificativa à baixa adoção de técnicas de gestão nas empresas agropecuárias.

Com relação à presença de ceticismo, por parte dos produtores e até dos técnicos, quanto à necessidade e a eficácia de se usar técnicas de gestão nas empresas rurais, alguns depoimentos merecem destaque: "nossos maiores problemas são as variações de mercado e o governo"; "o produtor não sente necessidade de um controle rigoroso. É melhor ele ser ativo na propriedade do que perder tempo com controles rigorosos"; "acho que o meu planejamento e controle empíricos são razoáveis"; "para pequenos produtores, programas comuns de gerenciamento trazem bons resultados, apenas corrigindo fundamentos básicos". 
Já a maior preocupação histórica de produtores e técnicos com questões tecnológicas foi amplamente apontada nos depoimentos. Nesse aspecto, destacam-se os seguintes argumentos: "primeiro é preciso melhorar a tecnologia, depois se preocupar com gestão"; "o produtor e a assistência técnica só pensam em aumentar a produtividade. Ninguém pára (nem produtores, nem técnicos) para pensar e identificar onde estão as gorduras e fazer contas"; "nós fazemos assistência tecnológica e somos despachantes na área do planejamento e do crédito"; "o agrônomo também só pensa em tecnologia e esquece da parte administrativa"; "o agrônomo não desperta ou incentiva o produtor para trabalhar com gestão".

A baixa tradição dos produtores rurais em divulgar à terceiros informações sobre sua real situação econômica, financeira e patrimonial, também foi amplamente citada nos depoimentos, quais sejam: "o produtor pode até ser austero com relação a gastos, mas a família não o é. Se o agrônomo tocar nessa ferida (gastos familiares) você perde o seu cliente (produtor rural)"; "o produtor não dá acesso ao técnico à informações sobre a parte financeira, mesmo se esse for o problema mais importante da propriedade. Só permite acesso às questões tecnológicas"; "o produtor não permite o acesso do técnico as contas pessoais ou da família, que estão misturadas com a conta da propriedade"; "hoje a relação entre produtor e agrônomo é puramente comercial. Não há mais aquela aproximação como antes. Se você não conhece o produtor, nada você pode fazer em gestão. A confiança que o agricultor tem em você é fundamental"; "o agricultor de forma alguma permite que o técnico tenha acesso aos dispêndios pessoais ou familiares"; "não dá lucro para as empresas ajudar o produtor na administração de sua propriedade. O que dá lucro é vender insumos"; "os agrônomos querem vender o produto da empresa onde trabalham"; "o agrônomo não conhece o produtor. Não sabe como ele administra a propriedade. Não sabe sobre sua situação financeira. É difícil fazer recomendações administrativas. O médico, por exemplo, procura saber quase tudo antes de dar o seu diagnóstico e recomendar um tratamento". 
A baixa tradição dos produtores rurais do país em contratar serviços regulares de assessoria em outras áreas, que não aquelas relacionadas aos aspectos tecnológicos surgem, de forma indireta, em alguns depoimentos, tais como: "por falta de formação ele não demanda serviços de gestão"; "o produtor precisa do efeito demonstração para se sensibilizar e fazer a adoção das práticas de gestão. Falta tempo para o técnico criar esse efeito demonstração"; "nas questões tecnológicas criar o efeito demonstração é mais fácil. É difícil mostrar que a gestão vai aumentar, por exemplo, a produção de soja do produtor"; "o acompanhamento de gestão é diário. O produtor é que tem que fazer. O técnico não tem tempo para isso"; "os produtores estão muito mal acostumados. Acham que o técnico tem que fazer tudo para eles"; "sem maior educação formal o produtor não vai demandar dos técnicos serviços de gestão"; "o processo de desenvolvimento da administração rural está apenas iniciando. Esse processo exige um longo prazo para a sua consolidação"; "a administração é coisa que o próprio produtor deve fazer. Não é uma atividade possível de ser repassada a outras pessoas”.

Pelo exposto, vários fatores limitantes atuam conjuntamente como inibidores à adoção de técnicas de gestão nas propriedades rurais. Pela limitação da técnica de pesquisa do grupo focal esses resultados não podem ser generalizados, mas ajudam na percepção e no estabelecimento de um quadro inicial sobre o problema. $\mathrm{Na}$ sequiência da pesquisa, esses resultados qualitativos foram testados, junto a quatro grupos de pessoas: agricultores (produtores de grãos); pecuaristas (bovino de corte); profissionais da assistência técnica para a agricultura e profissionais da assistência técnica para a pecuária. Nesse caso, o principal objetivo do teste foi: (1) permitir um tratamento quantitativo a algumas variáveis que influenciam a adoção de técnicas de gestão nas propriedades rurais; (2) verificar as diferenças na comunicação interpessoal entre técnicos e produtores; e (3) subsidiar a proposição de formas alternativas para o gerenciamento de propriedades rurais. 


\subsection{Resultados quantitativos: diferenças de opiniões e percepções entre produtores rurais e profissionais da assistência técnica.}

Com o objetivo de facilitar a discussão dos resultados, nesta secção algumas questões (ou afirmações) do questionário serão tratadas em conjunto. Além disso, à medida que as questões vão sendo discutidas ao longo do texto, os respectivos resultados serão apresentados em tabelas logo em seguida, para facilitar a visualização dos dados. Nas tabelas que apresentam o valor da mediana é indicado, ao seu lado e entre parênteses, através de letras minúsculas $(a, b, c)$ se há diferença significativa $(\mathrm{P}<0,05)$ no grau de percepção dos entrevistados para cada afirmação contida no questionário.

A íntegra dos resultados é apresentada no apêndice 3, ao final do trabalho. No apêndice 3 encontram-se detalhados os seguintes resultados para cada uma das afirmações do questionário: (a) a tabela 26 que mostra a média, o desvio padrão, a mediana e os resultados do teste do qui-quadrado de razão de verossimilhança (teste $\mathrm{G}^{2}$ ) das notas atribuídas pelo total dos entrevistados; (b) a tabela 27 que mostra a distribuição de freqüência das notas atribuídas pelo total dos entrevistados; (c) a tabela 28 que mostra a mediana das notas atribuídas pelos entrevistados, segundo a indicação da atividade principal; (d) a tabela 29 que mostra a distribuição da freqüência das notas às questões, em intervalos de notas de 0 a 3,4 a 5 , e 7 a 10, segundo a atividade principal dos entrevistados.

Para iniciar a discussão dos resultados, cabe ressaltar que o teste do quiquadrado de razão de verossimilhança (teste $\mathrm{G}^{2}$ ) confirma a existência de associação da atividade principal dos entrevistados com várias afirmações do questionário. A tabela 26 (apêndice 3) apresenta os valores de significância para o qui-quadrado de razão de verossimilhança para as 36 afirmações do questionário. Do total das questões, em 24

delas o teste $G^{2}$ se mostra significativo indicando que em dois terços das afirmações do 
questionário há fortes indícios $(\mathrm{P}<0,05)$ de que a atividade principal se associa com o grau de concordância às questões formuladas. Isso confirma a existência de importantes diferenças de atitudes entre produtores e técnicos, com relação à administração da empresa agropecuária.

Conforme mostram os dados da Tabela 7, as afirmações 1,2 e 23 do questionário obtiveram ampla concordância dos entrevistados através de medianas $9,8 \mathrm{e}$ 9, respectivamente, para o total da amostra. Em conjunto, as três afirmações inicialmente comprovam a natureza familiar predominante nas empresas agropecuárias. A concordância dos entrevistados com a questão 2 comprova que a promoção do bem estar familiar é o principal objetivo da propriedade rural. A concordância com as afirmações 1 e 23, por sua vez, corrobora a hipótese anteriormente colocada de que a manutenção ou ampliação dos gastos da família normalmente tem certa prioridade sobre o desenvolvimento da empresa agropecuária, mesmo que isso possa retardar o seu crescimento. Tal decisão estratégica dos produtores rurais parece ser consciente e a ampla concordância (mediana 10) dos agricultores e pecuaristas com a questão 1 corrobora a hipótese. A mediana 9 para o total da amostra, obtida na questão 1, demonstra que existe ampla consciência dos entrevistados de que os gastos familiares tem crescido, na última década, a uma velocidade maior do que a receita líquida da propriedade rural. Uma discussão sobre vários indicadores sócio-econômicos do período mencionado (dados secundários) como, por exemplo, a redução do número de produtores rurais, o maior endividamento do setor agropecuário, o aumento do custo de vida (principalmente urbano), a menor participação do setor primário no Produto Interno Bruto - PIB do país, entre outros, poderiam corroborar os argumentos acima, mas isso foge ao escopo principal desse trabalho. Neste momento, o mais importante é discutir por que esse e outros problemas administrativos da empresa agropecuária não têm sido devidamente enfrentados nem pelos produtores rurais, nem pelos profissionais da assistência técnica. 
Tabela 7. Mediana das respostas às questões 1, 2 e 23, segundo a atividade principal do entrevistado e o total da amostra.

\begin{tabular}{ccccccc}
\hline Questões $^{1}$ & Agricultor & Pecuarista & $\begin{array}{c}\text { Técnicos p/ } \\
\text { agricultura }\end{array}$ & $\begin{array}{c}\text { Técnicos p/ } \\
\text { pecuária }\end{array}$ & $\begin{array}{c}\text { Outros } \\
\text { profissionais }\end{array}$ & $\begin{array}{c}\text { Total da } \\
\text { amostra }\end{array}$ \\
\hline 1 & $10(\mathrm{a})$ & $10(\mathrm{a})$ & $9(\mathrm{a})$ & $9(\mathrm{a})$ & $9(\mathrm{a})$ & 9 \\
2 & $8(\mathrm{ab})$ & $10(\mathrm{a})$ & $8(\mathrm{~b})$ & $7(\mathrm{~b})$ & $8(\mathrm{~b})$ & 8 \\
23 & $8(\mathrm{~b})$ & $9(\mathrm{ab})$ & $9(\mathrm{a})$ & $9(\mathrm{ab})$ & $8(\mathrm{~b})$ & 9 \\
\hline
\end{tabular}

${ }^{1}$ Redação das questões: (1) "Na última década, os gastos para a manutenção da família têm crescido a uma velocidade maior do que o aumento de receita líquida da propriedade rural". (2) "Promover um bom padrão de vida para a família é o principal objetivo da propriedade rural". (23) "A grande maioria dos produtores rurais não separa em seus registros os gastos da família e os gastos da propriedade".

Os resultados do teste da mediana apresentados na tabela 7, para um nível de significância de 5\% (P<0,05), permitem indicar que: (1) na questão 1 não há diferenças no grau de concordância entre os entrevistados, segundo a atividade principal; (2) na questão 2 o grau de concordância dos pecuaristas é maior do que dos técnicos de agricultura e pecuária; (3) na questão 23 o grau de concordância dos técnicos de agricultura é maior do que dos agricultores.

As respostas obtidas nas questões 3 e 4, apresentadas na Tabela 8, corroboram a hipótese acerca do inadequado enfrentamento de alguns problemas administrativos na empresa agropecuária, por parte dos produtores e técnicos. $\mathrm{Na}$ questão 3, que aborda alguns prováveis motivos que afetam o resultado econômico/financeiro da empresa agropecuária, obteve-se diferenças significativas de percepções entre a agricultura e a pecuária e entre produtores e técnicos. Nessa questão, a mediana foi de 8 para agricultores, 6 para técnicos de agricultura, 7 para pecuaristas e 3 para técnicos de pecuária. A diferença de opinião na afirmativa 3, entre os produtores e técnicos ligados à agricultura versus aqueles ligados à pecuária, é até natural, pois o resultado econômico/financeiro de atividades agrícolas é efetivamente mais afetado por 
variações de clima e preços do que as atividades pecuárias. Vale ressaltar, entretanto, as diferenças de percepção entre os produtores e os técnicos que os assistem. Pela mediana das respostas da questão 3, pode-se concluir que os técnicos reconhecem, muito mais que os produtores, a existência de problemas administrativos nas empresas agropecuárias. Entretanto, admitem pelas respostas da questão 4 (medianas entre 7 e 8), que não participam da solução do problema, pois reconhecem que atuam pouco em questões administrativas das propriedades rurais.

Os resultados do teste da mediana apresentados na tabela 8, para um nível de significância de 5\% ( $\mathrm{P}<0,05)$, permitem indicar que: (1) na questão 3 os agricultores possuem maior grau de concordância que os pecuaristas e técnicos de agricultura, e esses um maior grau de concordância do que os técnicos de pecuária.; (2) na questão 4 não há diferenças no grau de concordância entre os entrevistados, segundo a atividade principal.

Tabela 8. Mediana das respostas às questões 3 e 4 , segundo a atividade principal do entrevistado e o total da amostra.

\begin{tabular}{ccccccc}
\hline Questões $^{1}$ & Agricultor & Pecuarista & $\begin{array}{c}\text { Técnicos p/ } \\
\text { agricultura }\end{array}$ & $\begin{array}{c}\text { Técnicos p/ } \\
\text { pecuária }\end{array}$ & $\begin{array}{c}\text { Outros } \\
\text { profissionais }\end{array}$ & $\begin{array}{c}\text { Total da } \\
\text { amostra }\end{array}$ \\
\hline 3 & $8(\mathrm{a})$ & $7(\mathrm{~b})$ & $6(\mathrm{~b})$ & $3(\mathrm{c})$ & $6,5(\mathrm{~b})$ & 7 \\
4 & $8(\mathrm{a})$ & $8(\mathrm{a})$ & $8(\mathrm{a})$ & $7(\mathrm{a})$ & $8(\mathrm{a})$ & 8 \\
\hline
\end{tabular}

\footnotetext{
${ }^{1}$ Redação das questões: (3) "O resultado econômico/financeiro das atividades agropecuárias é afetado, muito mais por variações do clima e dos preços agrícolas, do que por problemas administrativos internos da propriedade rural". (4) "No atendimento ao produtor, a assistência técnica concentra seu trabalho na orientação da produção e atua pouco em questões administrativas das propriedades rurais".
}

Os motivos, para a baixa participação dos técnicos no enfrentamento dos problemas administrativos das empresas agropecuárias, são parcialmente abordados nas questões 24, 25 e 29 do questionário. Em linhas gerais, pode-se afirmar que a baixa 
participação dos técnicos no processo administrativo da empresa agropecuária se deve muito mais a determinadas atitudes negativas dos produtores rurais, do que a atitudes negativas dos técnicos sobre o problema. A significativa diferença de percepção entre os produtores rurais (mediana 8) e os técnicos (medianas entre 3 e 4) na questão $29^{36}$ corrobora essa hipótese, conforme mostra os dados da Tabela 9. Na questão 29, ao contrário dos técnicos, os produtores rurais concordam fortemente que as questões administrativas da empresa agropecuária são sua responsabilidade, e que os técnicos devem priorizar as questões tecnológicas, em sua prestação de serviço às propriedades rurais.

Tabela 9. Mediana das respostas às questões 17, 24, 25 e 29, segundo a atividade principal do entrevistado e o total da amostra.

\begin{tabular}{ccccccc}
\hline Questões $^{1}$ & Agricultor & Pecuarista & $\begin{array}{c}\text { Técnicos p/ } \\
\text { agricultura }\end{array}$ & $\begin{array}{c}\text { Técnicos p/ } \\
\text { pecuária }\end{array}$ & $\begin{array}{c}\text { Outros } \\
\text { profissionais }\end{array}$ & $\begin{array}{c}\text { Total da } \\
\text { amostra }\end{array}$ \\
\hline 17 & $5(\mathrm{a})$ & $7(\mathrm{a})$ & $6(\mathrm{a})$ & $7(\mathrm{a})$ & $5(\mathrm{a})$ & 5 \\
24 & $6(\mathrm{a})$ & $5(\mathrm{ab})$ & $2(\mathrm{bc})$ & $2(\mathrm{c})$ & $4(\mathrm{~b})$ & 4 \\
25 & $6(\mathrm{a})$ & $7(\mathrm{a})$ & $5(\mathrm{a})$ & $7(\mathrm{a})$ & $6(\mathrm{a})$ & 6 \\
29 & $8(\mathrm{a})$ & $8(\mathrm{a})$ & $3(\mathrm{c})$ & $4(\mathrm{c})$ & $6(\mathrm{~b})$ & 7 \\
\hline
\end{tabular}

\footnotetext{
${ }^{1}$ Redação das questões: (17) "O produtor rural recebe constantemente informações de muitas pessoas e instituições e de várias formas (até via TV). Isso dificulta a escolha do melhor produto (insumo) comercial a ser utilizado na propriedade". (24) "Alguns dados financeiros da propriedade (como o valor dos gastos familiares, o valor de dívidas, etc.) não são assunto para serem tratados com profissionais da assistência técnica. (25) "O envolvimento dos profissionais da assistência técnica com a venda de insumos inibe os produtores rurais, de receber deles, assessoria administrativa na propriedade". (29) "Se o profissional da assistência técnica prestar ao produtor uma boa orientação tecnológica, isso já é uma grande contribuição para a propriedade, pois questões administrativas são responsabilidade do produtor rural”.
}

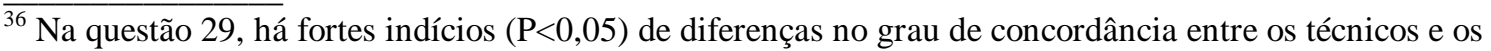
produtores.
} 
Com relação à assertiva da questão 25 , que afirma que o envolvimento dos técnicos com a venda de insumos os desqualifica como potenciais prestadores de assessoria administrativa aos produtores rurais, os resultados da mediana mostram que esse problema é um pouco maior na área pecuária (mediana 7 para técnicos de pecuária e pecuaristas) e um pouco menor na área agrícola (mediana 6 para os agricultores e mediana 5 para os técnicos de agricultura). Da mesma forma, a assertiva da questão 17, que aborda a dificuldade do produtor rural em decidir sobre o produto comercial a ser utilizado na propriedade, também obteve medianas maiores na pecuária ( 7 para os técnicos em pecuária e para os pecuaristas) e medianas menores na agricultura (6 para os técnicos em agricultura e 5 para os agricultores). Embora sem significância estatística ao nível de 5\% (ou seja, não há indícios de diferenças nas questões 17 e 25 entre as médias verdadeiras de concordância entre os entrevistados), a menor relevância desse problema na agricultura, em parte, pode ser explicada pela maior difusão de informações nesse setor, relativamente à pecuária.

Outra restrição à maior participação dos técnicos no processo administrativo das empresas agropecuárias diz respeito ao sigilo de informações. O tema gasto familiar é um deles, e foi bastante abordado durante os grupos focais, onde se argumentou que os produtores rurais normalmente não permitem o acesso dos técnicos às informações relacionadas a gastos familiares, mesmo quando esse assunto representa um problema administrativo importante na empresa agropecuária. A questão 24 abrange esse assunto com a seguinte expressão: "alguns dados financeiros da propriedade rural (como o valor dos gastos familiares, o valor das dívidas, etc.) não são assunto para serem tratados com profissionais da assistência técnica”. As notas atribuídas a essa questão mostram forte discordância dos técnicos (com mediana 2) à assertiva e relativa insegurança $^{37}$ dos produtores rurais em expressar sua opinião sobre o assunto. $\mathrm{Na}$ questão 24, a análise estatística $(\mathrm{P}<0,05)$ dos resultados indica que agricultores e técnicos de agricultura possuem diferentes graus de concordância entre si, o mesmo 
ocorrendo entre pecuaristas e técnicos de pecuária. No caso dos produtores rurais, as notas atribuídas à assertiva 24 também se mostram bem dispersas, pois $35 \%$ dos pecuaristas e $32 \%$ dos agricultores atribuíram notas de 0 a 3 a essa questão, enquanto $45 \%$ dos pecuaristas e $45 \%$ dos agricultores atribuíram notas de 7 a 10 para a questão 24 (Tabela10).

Tabela 10. Identificação da freqüência percentual (\%) para alguns intervalos de notas atribuídos à questão $24^{1}$, segundo a atividade principal do entrevistado.

\begin{tabular}{lccc}
\hline \multicolumn{1}{c}{ Atividade principal } & Notas de 0 a 3 & Notas de 4 a 6 & Notas de 7 a 10 \\
\hline Agricultor & 32 & 23 & 45 \\
Pecuarista & 35 & 20 & 45 \\
Assistência técnica p/ agricultura & 55 & 17 & 28 \\
Assistência técnica p/ pecuária & 67 & 10 & 23 \\
Outra atividade & 44 & 27 & 29 \\
\hline Total da amostra & 42 & 22 & 36 \\
\hline
\end{tabular}

${ }^{1}$ Redação da questão: (24) "Alguns dados financeiros da propriedade (como o valor dos gastos familiares, o valor de dívidas, etc.) não são assunto para serem tratados com profissionais da assistência técnica.

Em suma, a análise das questões mencionadas acima contribui para elucidar parcialmente o problema central do presente estudo, que está relacionado ao baixo uso de técnicas de gestão nas empresas agropecuárias e ao baixo envolvimento dos profissionais da assistência técnica com as questões administrativas dessas empresas. Da mesma forma, confirmam a existência de diferentes opiniões e percepções sobre o problema, por parte dos produtores e dos profissionais da assistência técnica. Nos subitens, a seguir, o problema central da pesquisa será abordado em partes segundo o modelo teórico proposto, que subdivide o processo administrativo das empresas agropecuárias em várias atividades administrativas. As funções administrativas de

$\overline{37}$ Do total de 241 agricultores e pecuaristas, 5\% deles não responderam a questão 24 (deixando-a em branco). No questionário, essa percentagem só foi superada pela questão 12 , onde $6 \%$ produtores rurais deixaram a questão em branco. 
planejamento, organização, direção e controle servirão de base para se subdividir a apresentação e discussão dos resultados obtidos com a aplicação dos questionários, visando um maior detalhamento do assunto e uma melhor compreensão do problema.

\subsubsection{Planejamento}

As questões 5 a 12 do questionário abordam temas relacionados ao planejamento da produção, das finanças, da comercialização e do pessoal.

A questão 5 trata de variáveis que interferem na definição do "mix" de produção da empresa agropecuária. A assertiva da questão 5 sugere que o produtor rural normalmente mantém seu planejamento de produção de longo prazo, em função das incertezas sobre os preços futuros e pela necessidade de usar a infraestrutura já existente na empresa agropecuária. A mediana 7 para o total da amostra, apresentada na Tabela 11, indica certa concordância dos entrevistados com a assertiva da questão 5. Isso parece indicar que, normalmente, há pouca flexibilidade no estabelecimento do "mix" de produção da empresa agropecuária, resultando em curvas de oferta relativamente inelásticas em relação aos preços de mercado. Assim, variáveis como o custo de aprendizagem na empresa sobre os processos produtivos e o custo para se alterar a estrutura física existente na empresa agropecuária devem merecer maior atenção dos pesquisadores, quando se pretende estudar a curva de oferta dessas empresas. Além disso, a percepção de produtores e técnicos sobre a assertiva da questão 5, parece também indicar que ainda existe certa desconfiança dessas pessoas, sobre a capacidade de previsão dos analistas de mercado, quanto ao comportamento futuro dos preços dos produtos agropecuários. 
Tabela 11. Mediana das respostas às questões 5, 6 e 7, segundo a atividade principal do entrevistado e o total da amostra.

\begin{tabular}{ccccccc}
\hline Questões $^{1}$ & Agricultor & Pecuarista & $\begin{array}{c}\text { Técnicos p/ } \\
\text { agricultura }\end{array}$ & $\begin{array}{c}\text { Técnicos p/ } \\
\text { pecuária }\end{array}$ & $\begin{array}{c}\text { Outros } \\
\text { profissionais }\end{array}$ & $\begin{array}{c}\text { Total da } \\
\text { amostra }\end{array}$ \\
\hline 5 & $7(\mathrm{a})$ & $7(\mathrm{a})$ & $7(\mathrm{a})$ & $6(\mathrm{a})$ & $7(\mathrm{a})$ & 7 \\
6 & $2(\mathrm{a})$ & $2,5(\mathrm{a})$ & $0(\mathrm{bc})$ & $0(\mathrm{c})$ & $1(\mathrm{~b})$ & 1 \\
7 & $6(\mathrm{a})$ & $5(\mathrm{ab})$ & $4(\mathrm{~b})$ & $3(\mathrm{~b})$ & $5(\mathrm{ab})$ & 5 \\
\hline
\end{tabular}

\footnotetext{
${ }^{1}$ Redação das questões: (5) A necessidade de usar a infraestrutura existente na propriedade e a incerteza quanto aos preços futuros (que podem ser altos ou baixos) estimula o produtor rural a manter sua produção, de acordo com o seu planejamento de longo prazo. (6) "É preferível fazer o planejamento da propriedade mentalmente e não por escrito, pois são constantes as mudanças na política econômica, no clima e nos preços. O planejamento mental é mais versátil do que o planejamento escrito". (7) "Se o produtor rural começar a fazer muitas contas no papel e verificar os prováveis resultados, ele poderia perder o estímulo de produzir".
}

A tendência de um maior uso do planejamento escrito na empresa agropecuária foi confirmada pelas respostas atribuídas a questão 6 , corroborando a hipótese anteriormente formulada sobre esse assunto. Na questão 6, tanto os técnicos (mediana 0) como os produtores (medianas entre 2 e 2,5) rejeitaram fortemente ${ }^{38}$ a assertiva enunciada de que o planejamento mental é mais versátil do que o planejamento escrito. Isso demonstra, também, a possibilidade de uma tendência favorável ao aumento de demanda para serviços de assessoria administrativa a produtores rurais comerciais. Tendo em vista o menor grau de discordância dos produtores rurais, em relação aos técnicos, na questão 6, pode-se sugerir que o processo de formalização do planejamento nas empresas agropecuárias não deve ser muito complexo, ou seja, não se deve passar de uma situação extrema de não uso do planejamento escrito, para uma outra situação extrema, de se querer planejar tudo por escrito. As respostas dos produtores à questão 7, reforçam essa "recomendação". A assertiva da questão 7 propõe a possibilidade de o produtor rural perder o estímulo de produzir, se ele começar a fazer muitas contas no papel e verificar os possíveis resultados. Uma análise sobre a mediana e a distribuição de 
freqüência das respostas a essa assertiva sugere a existência de controvérsias sobre o assunto $^{39}$. Na questão 7 obteve-se as seguintes medianas ${ }^{40}$ : agricultores (6), pecuaristas (5), técnicos para a agricultura (4) e técnicos para a pecuária (3). Com relação à distribuição de frequiência das respostas à questão 7, apresentadas na tabela 12, pode-se destacar: (a) 46\% dos agricultores, $43 \%$ dos pecuaristas, $28 \%$ dos técnicos de agricultura e $21 \%$ dos técnicos de pecuária atribuíram notas de 7 a 10 à referida questão; (b) $31 \%$ dos agricultores, $32 \%$ dos pecuaristas, $48 \%$ dos técnicos de agricultura e $51 \%$ dos técnicos de pecuária atribuíram notas de 0 a 3 à referida questão. Neste sentido, dadas as controvérsias expostas pela análise da questão 7 , pode-se concluir que não se deve tentar padronizar recomendações sobre a forma como o planejamento por escrito deva ser implantado e conduzido nas empresas agropecuárias. Provavelmente, algumas características pessoais do produtor rural (habilidades para manipular números, seu empreendedorismo, seu grau de escolaridade, entre outros) devem interferir em sua percepção sobre o tipo de planejamento mais conveniente, tornando necessário maiores estudos sobre o assunto.

Tabela 12. Identificação da freqüência percentual (\%) para alguns intervalos de notas atribuídos à questão $7^{1}$, segundo a atividade principal do entrevistado.

\begin{tabular}{lccc}
\hline \multicolumn{1}{c}{ Atividade principal } & Notas de 0 a 3 & Notas de 4 a 6 & Notas de 7 a 10 \\
\hline Agricultor & 31 & 23 & 46 \\
Pecuarista & 32 & 25 & 43 \\
Assistência técnica p/ agricultura & 48 & 24 & 28 \\
Assistência técnica p/ pecuária & 51 & 28 & 21 \\
Outra atividade & 39 & 20 & 41 \\
\hline Total da amostra & 37 & 23 & 40 \\
\hline
\end{tabular}

${ }^{1}$ Redação da questão: (7) "Se o produtor rural começar a fazer muitas contas no papel e verificar os prováveis resultados, ele poderia perder o estímulo de produzir".

\footnotetext{
$\overline{38} \mathrm{O}$ teste da mediana $(\mathrm{P}<0,05)$ indica que a rejeição dos técnicos é maior do que a dos produtores.

${ }^{39}$ Dentre todas as afirmações do questionário, a questão 7 é a que apresenta o maior desvio padrão $(3,53)$ para as notas atribuídas pelo total dos entrevistados.
} 
Uma análise em conjunto das notas atribuídas as questões 8, 9 e 10, apresentadas na Tabela 13, permite concluir sobre a fragilidade do planejamento financeiro e comercial, normalmente utilizado nas empresas agropecuárias. $\mathrm{O}$ inadequado planejamento financeiro talvez seja um dos problemas mais importantes nessas empresas, pois uma má administração do fluxo de caixa pode resultar, por exemplo: na impossibilidade de se realizar gastos ou investimentos em ora oportuna; na necessidade de se comercializar a produção a qualquer preço; e em muitos outros prejuízos advindos da baixa liquidez financeira da empresa agropecuária. Neste sentido, temos observado ${ }^{41}$ uma grande diferença no resultado econômico/financeiro entre empresas agropecuárias semelhantes, mas que trabalham com maior ou menor disponibilidade de dinheiro em caixa. Aquelas com maior liquidez tem obtido, sistematicamente, melhores resultados na compra de insumos, na venda da produção, no pagamento de juros, e até mesmo nos níveis de produtividade. As medianas de valor 8 para toda a amostra, obtidas nas questões 8, 9 e 10, sugerem que os produtores rurais normalmente não aplicam seus recursos em ativos financeiros de alta liquidez. Preferem trabalhar com maior estoque patrimonial e com baixa liquidez no caixa, gerando recursos financeiros apenas para saldar compromissos vincendos no curto prazo. Cabe ressaltar, entretanto, que essa estratégia adotada pela maioria das empresas agropecuárias, embora bastante inadequada sob o aspecto financeiro e comercial da empresa agropecuária, têm lhes proporcionado alguns benefícios indiretos e que precisam ser mais bem avaliados, tais como: (a) contenção dos gastos familiares, que provavelmente seriam maiores se houvesse maior liquidez no caixa (em função da forte pressão exercida pela família para a ampliação do consumo familiar); (b) necessidade percebida de manter um alto imobilizado que é requerido como garantia de operações creditícias; (c) maior possibilidade de adoção de determinadas tecnologias de produção, com conseqüente maior possibilidade de elevar os níveis de produtividade da terra.

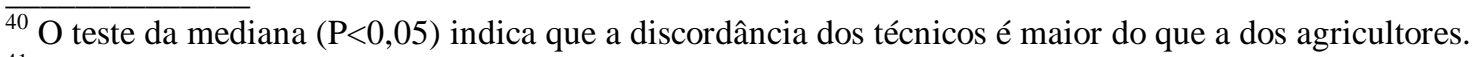

${ }^{41} \mathrm{Em}$ assessorias administrativas prestadas pelo autor a produtores rurais.
} 
Tabela 13. Mediana das respostas às questões 8,9 e 10, segundo a atividade principal do entrevistado e o total da amostra.

\begin{tabular}{ccccccc}
\hline Questões $^{1}$ & Agricultor & Pecuarista & $\begin{array}{c}\text { Técnicos p/ } \\
\text { agricultura }\end{array}$ & $\begin{array}{c}\text { Técnicos p/ } \\
\text { pecuária }\end{array}$ & $\begin{array}{c}\text { Outros } \\
\text { profissionais }\end{array}$ & $\begin{array}{c}\text { Total da } \\
\text { amostra }\end{array}$ \\
\hline 8 & $9(\mathrm{a})$ & $9(\mathrm{a})$ & $9(\mathrm{a})$ & $8(\mathrm{a})$ & $8(\mathrm{a})$ & 8 \\
9 & $8(\mathrm{a})$ & $9(\mathrm{a})$ & $8(\mathrm{a})$ & $8(\mathrm{a})$ & $8(\mathrm{a})$ & 8 \\
10 & $8(\mathrm{a})$ & $9(\mathrm{a})$ & $8(\mathrm{ab})$ & $7(\mathrm{~b})$ & $8(\mathrm{a})$ & 8 \\
\hline
\end{tabular}

${ }^{1}$ Redação das questões: (8) "A necessidade de caixa (dinheiro) para pagar compromissos financeiros, normalmente é o que determina o momento da venda da produção". (9) "Os produtores rurais preferem trabalhar as suas atividades com maior estoque patrimonial (terras, máquinas, animais) do que com maior liquidez no caixa (disponibilidade financeira). Por isso, em anos de sobra de caixa, preferem investir na propriedade do que guardar o dinheiro no banco". (10) A principal dificuldade para se planejar a compra de insumos é a falta de recursos financeiros na propriedade em determinadas épocas do ano.

Alguns detalhes sobre o planejamento da área de recursos humanos são abordados nas questões 11 e 12 . Para as duas questões, a mediana das respostas dos produtores rurais oscilou entre 7 e 9 , e dos técnicos entre 7 e 8 , indicando certa similaridade de opinião sobre o assunto, que foram confirmados pelo teste da mediana, conforme mostram os dados da Tabela 14. A concordância dos entrevistados de que a legislação trabalhista brasileira é mais adaptada ao meio urbano sendo, portanto, mais difícil de cumpri-la integralmente nas propriedades rurais, parece indicar certo ceticismo dos entrevistados, com relação à possibilidade técnica de se prever a rotina de serviços operacionais na propriedade rural. Essa percepção, aliás, é parcialmente correta, pois o clima afeta diretamente o rendimento dos serviços manuais no campo, e a sazonalidade da produção agropecuária faz oscilar bastante a demanda por mão-de-obra ao longo do tempo nessas empresas. Ademais, deve existir uma produtividade marginal de conveniência $^{42}$ em se trabalhar com pequeno excedente de mão-de-obra nas empresas

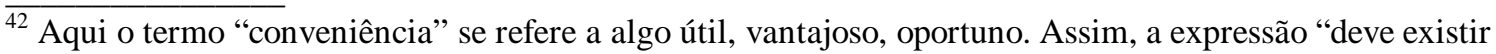
uma produtividade marginal de conveniência" quer dizer "que há, provavelmente, uma utilidade marginal positiva em se trabalhar com pequeno excedente de mão-de-obra".
} 
agropecuárias. Provavelmente, os ganhos dessa estratégia, no dimensionamento do quadro funcional, devem-se: (1) a importância de se executar os serviços manuais em hora oportuna; (2) ao fato da mão-de-obra temporária e fixa não serem substitutos perfeitos no meio agropecuário, em função do custo de aprendizagem dos trabalhos manuais na empresa; (3) a possibilidade de se alocar a mão-de-obra excedente em outras atividades de menor relevância econômica na empresa agropecuária; (4) a baixa remuneração geralmente paga à mão-de-obra no meio rural brasileiro.

Tabela 14. Mediana das respostas às questões 11 e 12, segundo a atividade principal do entrevistado e o total da amostra.

\begin{tabular}{ccccccc}
\hline Questões $^{1}$ & Agricultor & Pecuarista & $\begin{array}{c}\text { Técnicos p/ } \\
\text { agricultura }\end{array}$ & $\begin{array}{c}\text { Técnicos p/ } \\
\text { pecuária }\end{array}$ & $\begin{array}{c}\text { Outros } \\
\text { profissionais }\end{array}$ & $\begin{array}{c}\text { Total da } \\
\text { amostra }\end{array}$ \\
\hline 11 & $9(\mathrm{a})$ & $9(\mathrm{a})$ & $8(\mathrm{a})$ & $8(\mathrm{a})$ & 8 (a) & 8 \\
12 & $8(\mathrm{a})$ & $7(\mathrm{a})$ & $7(\mathrm{a})$ & 7 (a) & 7 (a) & 7 \\
\hline
\end{tabular}

${ }^{1}$ Redação das questões: (11) "A legislação trabalhista é mais adaptada ao meio urbano. Por isso, em propriedades rurais, é mais difícil cumpri-la integralmente". (12) "As propriedades rurais normalmente trabalham com ociosidade de mão-de-obra fixa, pois na média anual, o número de empregados fixos é determinado em função dos períodos de maior necessidade de trabalho".

\subsubsection{Organização}

As questões 13 a 20 do questionário abordam temas relacionados a função administrativa organização. As questões relacionam-se a organização da produção, das finanças, da comercialização e do pessoal.

$\mathrm{Na}$ organização da empresa agropecuária, a maior parte do tempo de trabalho, despendidos por produtores e técnicos, é direcionada para a área de produção. A mediana 8, obtida nas questões de número 4 e 13, aponta nesta direção, conforme 
mostra a Tabela 15. Na empresa agropecuária, o estabelecimento dessa prioridade de trabalho é até recomendável, tendo em vista que uma boa organização da produção é condição necessária (porém não suficiente) para o sucesso de qualquer empreendimento agropecuário, quase sempre realizado ao ar livre e de forma dispersa na propriedade.

Tabela 15. Mediana das respostas às questões 4, 13 e 14, segundo a atividade principal do entrevistado e o total da amostra.

\begin{tabular}{ccccccc}
\hline Questões & Agricultor & Pecuarista & $\begin{array}{c}\text { Técnicos p/ } \\
\text { agricultura }\end{array}$ & $\begin{array}{c}\text { Técnicos p/ } \\
\text { pecuária }\end{array}$ & $\begin{array}{c}\text { Outros } \\
\text { profissionais }\end{array}$ & $\begin{array}{c}\text { Total da } \\
\text { amostra }\end{array}$ \\
\hline 4 & $8(\mathrm{a})$ & $8(\mathrm{a})$ & $8(\mathrm{a})$ & $7(\mathrm{a})$ & $8(\mathrm{a})$ & 8 \\
13 & $8(\mathrm{~b})$ & $8(\mathrm{~b})$ & $9(\mathrm{a})$ & $8(\mathrm{ab})$ & $8(\mathrm{~b})$ & 8 \\
14 & $7(\mathrm{a})$ & $8(\mathrm{a})$ & $7(\mathrm{a})$ & $7(\mathrm{a})$ & 7 (a) & 7 \\
\hline
\end{tabular}

\footnotetext{
${ }^{1}$ Redação das questões: (4) "No atendimento ao produtor, a assistência técnica concentra seu trabalho na orientação da produção e atua pouco em questões administrativas das propriedades rurais". (13) "O produtor rural tem uma maior preocupação com os aspectos de produção (tecnologia) do que pelos aspectos administrativos de sua propriedade". (14) "As propriedades rurais normalmente trabalham com infraestrutura ociosa (máquinas, equipamentos, etc.), pois na média anual, o tamanho dessa infraestrutura é determinado em função da possibilidade de ocorrer períodos críticos (adversidades climáticas, etc)”.
}

A busca de uma eficiente organização da produção na empresa agropecuária, se não bem coordenada, pode resultar em problemas econômicos e administrativos. O bom arranjo dos campos e benfeitorias e a eficiência de logística no uso do maquinário e no estabelecimento correto da seqüência de tarefas são condições fundamentais para uma boa organização da produção. O correto dimensionamento do maquinário, enquanto uma atividade administrativa, também está relacionada à organização da produção. Quando o maquinário é superdimensionado, ele resulta em aumento dos custos fixos da propriedade, e quando subdimensionado ele dificulta a direção operacional da produção. A mediana 7 obtida na questão 14 e o teste da mediana constatam que, tanto técnicos como produtores, concordam que a maioria das 
propriedades rurais possui infraestrutura ociosa (máquinas, equipamentos, etc.) a fim de suprir a demanda por esses bens de capital nos períodos críticos. Em parte, isso se deve: (1) à busca de independência pelo produtor com relação ao funcionamento da propriedade (direção operacional da produção), devido à baixa disponibilidade no mercado de serviços de mecanização terceirizados ${ }^{43}$. Na maioria dos casos, são os próprios produtores rurais que prestam, quando "podem", esses serviços a outros produtores. Normalmente, não há uma conotação empresarial para esses serviços, mas sim uma conotação de "ajuda" a quem precisa; (2) à rápida evolução tecnológica, sobretudo na área de máquinas e equipamentos agrícolas, que aceleram a depreciação tecnológica desses bens de capital e exigem sua substituição em curtos espaços de tempo. Assim, há que se reconhecer a existência de uma produtividade marginal de conveniência, em se trabalhar com pequena ociosidade de infraestrutura nas empresas agropecuárias. Provavelmente, os ganhos dessa estratégia devem-se: (a) a importância de se executar os serviços mecanizados em hora oportuna, reduzindo os riscos de produção; (b) a melhoria da imagem (status) dos produtores que possuem maior e melhor infraestrutura física em suas propriedades. Portanto, esses ganhos devem ser considerados em avaliações econômicas, que pretendam determinar a infraestrutura ótima para as empresas agropecuárias.

Com relação à organização das finanças da propriedade rural, duas hipóteses, aparentemente incompatíveis entre si, foram apontadas anteriormente: (1) maior disposição dos produtores em usar controles gerenciais (planos de contas e centros de custos) mais detalhados e (2) a preferência dos produtores pelo uso de softwares mais simples de manipular e que gerem resultados mais fáceis de interpretar. Elas, porém, foram em parte confirmadas pelas respostas atribuídas às questões 15 e 16, conforme mostram os dados da Tabela 16. A assertiva da questão 16, amplamente aceita por produtores e técnicos (medianas entre 8 e 9), sugere que o produtor rural tem dificuldade para entender e utilizar os "softwares" desenvolvidos para o meio rural. Na assertiva da

43 Serviços terceirizados de colheita e transporte da produção são os mais comuns no mercado agropecuário. 
questão 15, por sua vez, sugere-se que o mais importante é conhecer os resultados globais da propriedade, pois muitas diferenças entre talhões/lotes não podem ser controladas pelo produtor. Essa assertiva foi parcialmente rejeitada pelos técnicos (mediana 3) e apresentou certa indiferença na opinião dos produtores rurais (medianas 5 e 6 , respectivamente, para agricultores e pecuaristas ${ }^{44}$. Isso provavelmente significa que existe atitude favorável para controles gerenciais mais detalhados, mas também se reconhece a dificuldade de implementá-los na empresa agropecuária. A solução para essas questões depende de um aperfeiçoamento dos "softwares" existentes no mercado, através de esforços conjuntos de programadores (com experiência na administração de empresas agropecuárias) e de profissionais da assistência técnica (com experiência na programação de sistemas informatizados).

Tabela 16. Mediana das respostas às questões 15 e 16, segundo a atividade principal do entrevistado e o total da amostra.

\begin{tabular}{ccccccc}
\hline Questões $^{1}$ & Agricultor & Pecuarista & $\begin{array}{c}\text { Técnicos p/ } \\
\text { agricultura }\end{array}$ & $\begin{array}{c}\text { Técnicos p/ } \\
\text { pecuária }\end{array}$ & $\begin{array}{c}\text { Outros } \\
\text { profissionais }\end{array}$ & $\begin{array}{c}\text { Total da } \\
\text { amostra }\end{array}$ \\
\hline 15 & $5(\mathrm{~b})$ & $6(\mathrm{a})$ & $3(\mathrm{c})$ & $3(\mathrm{bc})$ & $5(\mathrm{~b})$ & 5 \\
16 & $8(\mathrm{~b})$ & $9(\mathrm{ab})$ & $9(\mathrm{a})$ & $9(\mathrm{ab})$ & $8(\mathrm{~b})$ & 9 \\
\hline
\end{tabular}

\footnotetext{
${ }^{1}$ Redação das questões: (15) "Na avaliação da propriedade, o mais importante é conhecer os resultados globais, pois as diferenças de resultados entre talhões/lotes geralmente se devem a questões climáticas ou a outras variáveis que não podem ser controladas pelo produtor". (16) "O produtor rural tem dificuldade para entender e utilizar os softwares (programas de computador) desenvolvidos para o meio rural".
}

Na organização da comercialização na empresa agropecuária há que se diferenciar as compras e vendas. Na compra de insumos os produtores rurais geralmente se defrontam com fornecedores que compõem um mercado oligopolizado, mas que ofertam uma ampla variedade de produtos alternativos. A grande velocidade das

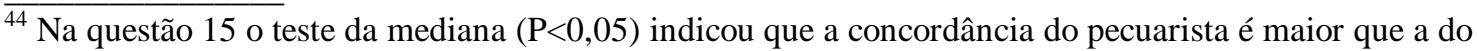
agricultor e esta é maior do que a do técnico de agricultura.
} 
inovações tecnológicas nesse mercado dificulta o seu acompanhamento pelo produtor rural, induzindo-o, periodicamente, a buscar novas informações através de publicidades, através de participação em eventos de promoção ou lançamento de produtos, entre outras formas. A assertiva 17 do questionário sugere que o produtor rural tem dificuldade em discernir sobre as diferentes informações disponíveis a ele, conforme mostram os dados da Tabela 17. Essa assertiva foi parcialmente aceita pelos pecuaristas e técnicos de pecuária (mediana 7), e um pouco menos pelos técnicos de agricultura (mediana 6) e pelos agricultores (mediana 5). O teste da mediana, porém, indica que não há diferenças de opinião entre os entrevistados para um nível de significância de 5\%. Em parte, a menor concordância (expressa pela mediana) dos agricultores e técnicos dessa área, sobre a assertiva da questão 17, pode estar relacionada a maior difusão de informações nesse mercado relativamente à pecuária. Essa menor concordância ou não reconhecimento das dificuldades em discernir sobre as informações tecnológicas pode, também, estar associada à satisfação pessoal de agricultores e técnicos de agricultura em receber constante assédio, através do “marketing” desenvolvido pelas empresas fornecedoras de insumos.

$\mathrm{Na}$ venda da produção agropecuária há amplo reconhecimento dos entrevistados, sobre a pressão que os produtores rurais sofrem de empresas e/ou cooperativas para que sejam fiéis na entrega da produção. Aqui o termo fidelidade significa cumprir o compromisso de entregar ${ }^{45}$ a produção à empresa que lhe concedeu algum auxílio de crédito, de serviços, etc. As respostas à questão 18 confirmam a proposição, através de medianas variando entre 7 e 9. Mantido esse quadro, há que se ressaltar a tendência provável de maior interdependência futura entre os processos de compra e venda na empresa agropecuária, com os produtores rurais (sobretudo os agricultores) adquirindo insumos e entregando a produção para a mesma empresa. Nesse processo de maior integração comercial entre os produtores rurais e seus clientes e fornecedores, provavelmente, questões como relacionamento, confiança, reciprocidade e

$\overline{45} \mathrm{Na}$ agricultura, o uso do termo "entregar a produção", significa disponibilizar a produção para processamento e comercialização através de determinada empresa. 
garantias serão cada vez mais valorizadas pelo mercado agropecuário. Pelo teste da mediana, na questão 18 o grau de concordância dos técnicos de agricultura é maior do que dos agricultores, e o dos agricultores e pecuaristas é maior do que dos técnicos para pecuária.

Tabela 17. Mediana das respostas às questões 17 e 18, segundo a atividade principal do entrevistado e o total da amostra.

\begin{tabular}{ccccccc}
\hline Questões $^{1}$ & Agricultor & Pecuarista & $\begin{array}{c}\text { Técnicos p/ } \\
\text { agricultura }\end{array}$ & $\begin{array}{c}\text { Técnicos p/ } \\
\text { pecuária }\end{array}$ & $\begin{array}{c}\text { Outros } \\
\text { profissionais }\end{array}$ & $\begin{array}{c}\text { Total da } \\
\text { amostra }\end{array}$ \\
\hline 17 & $5(\mathrm{a})$ & $7(\mathrm{a})$ & $6(\mathrm{a})$ & $7(\mathrm{a})$ & $5(\mathrm{a})$ & 5 \\
18 & $8(\mathrm{~b})$ & $9(\mathrm{ab})$ & $9(\mathrm{a})$ & $7(\mathrm{c})$ & $8(\mathrm{~b})$ & 8 \\
\hline
\end{tabular}

${ }^{1}$ Redação das questões: (17) "O produtor rural recebe constantemente informações de muitas pessoas e instituições e de várias formas (até via TV). Isso dificulta a escolha do melhor produto (insumo) comercial a ser utilizado na propriedade". (18) "Há uma grande pressão das empresas e/ou cooperativas sobre o produtor rural para que ele seja fiel na entrega de sua produção"

$\mathrm{Na}$ organização do pessoal na empresa agropecuária, a principal dificuldade é a concentração de trabalho na pessoa do produtor rural. Essa sobrecarga de trabalho, porém, geralmente não é reconhecida pelos profissionais da assistência técnica. As respostas obtidas nas questões 19 e 20 apontam nessa direção, conforme mostram os dados da Tabela 18. Em ambas as questões há grande divergência de percepção entre produtores e técnicos sobre o assunto. Pelo teste da mediana verifica-se que há fortes indícios de diferenças significativas $(\mathrm{P}<0,05)$ no grau de concordância entre os produtores rurais e os técnicos nas questões 19 e 20. Em linhas gerais, as assertivas das questões 19 e 20 sugerem que o produtor rural possui uma vida atribulada, em função dos serviços e tarefas operacionais de produção que exigem atenção permanente, e que dificultam a realização de tarefas administrativas de planejamento e controle, sobretudo nas áreas financeira e comercial. Os profissionais da assistência técnica discordam dessa assertiva (medianas entre 2 e 3), enquanto os agricultores (mediana 5) e pecuaristas 
(medianas entre 6 e 7) mostram-se divididos sobre o assunto. Provavelmente, nesse caso, a principal diferença na percepção dos dois grupos não se deve ao reconhecimento de que o produtor rural gasta a maior parte de seu tempo cuidando da produção, mas sim, ao fato de isso ser usado como justificativa para um menor envolvimento do produtor rural com os aspectos financeiros e comerciais da empresa agropecuária. A vida urbana hoje mantida pela maioria dos produtores rurais, e o conseqüente convívio social entre produtores e técnicos nas pequenas e médias cidades, também, pode estar influenciando os técnicos a não reconhecerem a falta de tempo alegada pelos produtores rurais. Por fim, outra possibilidade para a diferença de percepção entre os dois grupos nesse caso é o real desconhecimento dos técnicos sobre os afazeres administrativos dos produtores rurais.

Tabela 18. Mediana das respostas às questões 19 e 20, segundo a atividade principal do entrevistado e o total da amostra.

\begin{tabular}{ccccccc}
\hline Questões $^{1}$ & Agricultor & Pecuarista & $\begin{array}{c}\text { Técnicos p/ } \\
\text { agricultura }\end{array}$ & $\begin{array}{c}\text { Técnicos p/ } \\
\text { pecuária }\end{array}$ & $\begin{array}{c}\text { Outros } \\
\text { profissionais }\end{array}$ & $\begin{array}{c}\text { Total da } \\
\text { amostra }\end{array}$ \\
\hline 19 & $5(\mathrm{~b})$ & $6(\mathrm{a})$ & $2,5(\mathrm{c})$ & $2(\mathrm{c})$ & $4(\mathrm{bc})$ & 4 \\
20 & $5(\mathrm{~b})$ & $7(\mathrm{a})$ & $3(\mathrm{c})$ & $3(\mathrm{c})$ & $5(\mathrm{bc})$ & 5 \\
\hline
\end{tabular}

\footnotetext{
${ }^{1}$ Redação das questões: (19) "O produtor rural não tem tempo para fazer planejamento por escrito e manter controles pormenorizados. É uma correria todo dia, para executar os serviços e tarefas operacionais que exigem atenção permanente". (20) "Como o produtor tem que gastar a maior parte do seu tempo cuidando da produção, sobra a ele pouco tempo para analisar as áreas financeira e comercial da empresa rural".
} 


\subsubsection{Direção}

As questões 21 a 28 do questionário abordam temas relacionados a função administrativa direção. As questões relacionam-se a direção da produção, das finanças, da comercialização e do pessoal.

Uma análise conjunta das questões 21 e 22 apontam para a existência de diferentes percepções sobre a direção da produção na empresa agropecuária. Sabe-se que no passado, dada a maior regulação do mercado, a principal vantagem competitiva da empresa agropecuária era alicerçada em ganhos de produtividade. Atualmente, alguns produtores e a maioria dos técnicos já percebem que atingir boas produtividades é uma condição necessária, mas não suficiente para o sucesso econômico (alta lucratividade) dos empreendimentos agropecuários. As diferenças na percepção de técnicos e produtores sobre os enunciados das questões 21 e 22 apontam nessa direção, conforme mostram os dados das medianas e do teste da mediana na Tabela 19. O enunciado da questão 21 afirma: "os bons produtores são aqueles que obtém alta produtividade". O enunciado da questão 22, por sua vez, afirma: "primeiro é preciso melhorar a tecnologia para aumentar a produtividade, depois se preocupar com planos e controles para a propriedade". Para os técnicos, a mediana 5 na questão 21 e as medianas entre 2 e 3 na questão 22, parecem indicar que eles reconhecem a importância de se obter altas produtividades, mas percebem que isso não é suficiente para o sucesso econômico (alta lucratividade) do empreendimento. Já para os produtores, as medianas entre 7 e 8 na questão 21 e entre 5 e 6 na questão 22, parecem indicar que eles normalmente dirigem a área de produção a fim de atingir maiores índices de produtividade, mas esse esforço não é feito a qualquer custo (ou com ousadias exageradas), talvez por reconhecerem a queda na rentabilidade das atividades agropecuárias (riscos de mercado), e a conseqüente necessidade de se planejar e controlar melhor seus empreendimentos, em relação a forma como faziam no passado. 
Tabela 19. Mediana das respostas às questões 21 e 22, segundo a atividade principal do entrevistado e o total da amostra.

\begin{tabular}{ccccccc}
\hline Questões $^{1}$ & Agricultor & Pecuarista & $\begin{array}{c}\text { Técnicos p/ } \\
\text { agricultura }\end{array}$ & $\begin{array}{c}\text { Técnicos p/ } \\
\text { pecuária }\end{array}$ & $\begin{array}{c}\text { Outros } \\
\text { profissionais }\end{array}$ & $\begin{array}{c}\text { Total da } \\
\text { amostra }\end{array}$ \\
\hline 21 & $7(\mathrm{a})$ & $8(\mathrm{a})$ & $5(\mathrm{~b})$ & $5(\mathrm{~b})$ & $7(\mathrm{a})$ & 7 \\
22 & $5(\mathrm{ab})$ & $6(\mathrm{a})$ & $3(\mathrm{bc})$ & $2(\mathrm{c})$ & $4(\mathrm{~b})$ & 4 \\
\hline
\end{tabular}

\footnotetext{
${ }^{1}$ Redação das questões: (21) "Os bons produtores rurais são aqueles que obtém alta produtividade". (22) "Primeiro é preciso melhorar a tecnologia para aumentar a produtividade, depois se preocupar com planos e controles para a propriedade.
}

$\mathrm{Na}$ direção das finanças, os produtores rurais não separam em seus registros os gastos da família e da propriedade, conforme apontado pela mediana 9 na questão 23 do questionário e mostrada na Tabela 20. O teste da mediana indica que os técnicos de agricultura reconhecem ou concordam mais com a assertiva da questão 23 que trata desse problema, do que os agricultores. Conforme apontado anteriormente, esse procedimento é fortemente condenado pelos técnicos (mediana 2 na questão 24). Já os produtores rurais, embora reconheçam a existência desse e de outros problemas na direção das finanças da propriedade rural, muitas vezes não se dispõem a discuti-lo com a assistência técnica, provavelmente por julgarem que esses assuntos são de cunho particular (medianas entre 5 e 6 na questão 24). O teste da mediana na questão 24 comprova $(\mathrm{P}<0,05)$ diferenças de percepção entre agricultores (a) e técnicos de agricultura (bc) e entre pecuaristas (ab) e técnicos de pecuária (c).

De forma semelhante, a direção da comercialização na empresa agropecuária também é centralizada no produtor rural, conforme aponta as medianas entre 8 e 9 na questão 26. Nessa questão, o teste da mediana indica diferença significativa na percepção entre pecuaristas e técnicos de pecuária. A centralização da comercialização no produtor rural, em parte se deve a falta de funcionários qualificados nas propriedades rurais e, em parte, pela relação trabalhista que os profissionais da 
assistência técnica possuem com empresas que mantém relações comerciais com os produtores (medianas entre 5 e 7 na questão 25).

Tabela 20. Mediana das respostas às questões 23, 24, 25 e 26, segundo a atividade principal do entrevistado e o total da amostra.

\begin{tabular}{ccccccc}
\hline Questões $^{1}$ & Agricultor & Pecuarista & $\begin{array}{c}\text { Técnicos p/ } \\
\text { agricultura }\end{array}$ & $\begin{array}{c}\text { Técnicos p/ } \\
\text { pecuária }\end{array}$ & $\begin{array}{c}\text { Outros } \\
\text { profissionais }\end{array}$ & $\begin{array}{c}\text { Total da } \\
\text { amostra }\end{array}$ \\
\hline 23 & $8(\mathrm{~b})$ & $9(\mathrm{ab})$ & $9(\mathrm{a})$ & $9(\mathrm{ab})$ & $8(\mathrm{~b})$ & 9 \\
24 & $6(\mathrm{a})$ & $5(\mathrm{ab})$ & $2(\mathrm{bc})$ & $2(\mathrm{c})$ & $4(\mathrm{~b})$ & 4 \\
25 & $6(\mathrm{a})$ & $7(\mathrm{a})$ & $5(\mathrm{a})$ & $7(\mathrm{a})$ & $6(\mathrm{a})$ & 6 \\
26 & $9(\mathrm{ab})$ & $9(\mathrm{a})$ & $9(\mathrm{ab})$ & $8(\mathrm{~b})$ & $8(\mathrm{~b})$ & 9 \\
\hline
\end{tabular}

${ }^{1}$ Redação das questões: (23) "A grande maioria dos produtores rurais não separa em seus registros os gastos da família e os gastos da propriedade". (24) "Alguns dados financeiros da propriedade (como o valor dos gastos familiares, o valor de dívidas, etc.) não são assunto para serem tratados com profissionais da assistência técnica. (25) "O envolvimento dos profissionais da assistência técnica com a venda de insumos inibe os produtores rurais, de receber deles, assessoria administrativa na propriedade". (26) "Comprar e vender é tarefa do produtor rural. Raramente (à exceção das transações de pequenos valores) ela é delegada a funcionários da fazenda".

Com relação à direção do pessoal na empresa agropecuária a opinião dos produtores se mostrou extremamente controversa. Os dados da Tabela 21 mostram que nas questões 27 e 28 obteve-se medianas entre 5 e 6 para os produtores, com ampla variação na percepção de alguns pontos. Sobre a importância dos produtores estarem presentes na propriedade para realizarem controles visuais em substituição a controles escritos (questão 27) e sobre as ordens de serviços serem transmitidas de forma autocrática aos funcionários (questão 28), a opinião dos produtores mostrou-se bem dividida, com cerca de um terço das respostas em cada faixa de freqüência de 0 a 3,4 a 6, e 7 a 10, conforme mostram, respectivamente, os dados das Tabelas 22 e 23. Os técnicos, por sua vez, discordaram fortemente (medianas entre 0 e 2) das assertivas 
propostas nas questões 27 e 28 , resultando em uma opinião significativamente $(\mathrm{P}<0,05)$ diferente da emitida pelos produtores conforme apontam os dados do teste da mediana nessas questões. Através dessa opinião, os técnicos talvez estejam reconhecendo a importância da eficiência dos funcionários nos trabalhos operacionais da empresa agropecuária e criticando, indiretamente, a forma autocrática de liderança presente nas propriedades rurais.

Tabela 21. Mediana das respostas às questões 27 e 28, segundo a atividade principal do entrevistado e o total da amostra.

\begin{tabular}{ccccccc}
\hline Questões $^{1}$ & Agricultor & Pecuarista & $\begin{array}{c}\text { Técnicos p/ } \\
\text { agricultura }\end{array}$ & $\begin{array}{c}\text { Técnicos p/ } \\
\text { pecuária }\end{array}$ & $\begin{array}{c}\text { Outros } \\
\text { profissionais }\end{array}$ & $\begin{array}{c}\text { Total da } \\
\text { amostra }\end{array}$ \\
\hline 27 & $5(\mathrm{a})$ & $5(\mathrm{a})$ & $2(\mathrm{c})$ & $0(\mathrm{c})$ & $3(\mathrm{~b})$ & 4 \\
28 & $5(\mathrm{a})$ & $6(\mathrm{a})$ & $2(\mathrm{~b})$ & $2(\mathrm{~b})$ & $4(\mathrm{a})$ & 4 \\
\hline
\end{tabular}

${ }^{1}$ Redação das questões: (27) "No meio agropecuário não adianta muito querer controlar tudo por escrito. O importante é o responsável estar presente na propriedade, pois assim já estaria efetuando os controles de forma visual, mas permanente". (28) "No meio agropecuário, as ordens de serviço que os produtores repassam aos funcionários devem ser bem claras e diretas, pois não adianta muito ficar trocando idéias com os funcionários". 
Tabela 22. Identificação da freqüência percentual (\%) para alguns intervalos de notas atribuídos à questão $27^{1}$, segundo a atividade principal do entrevistado.

\begin{tabular}{lccc}
\hline \multicolumn{1}{c}{ Atividade principal } & Notas de 0 a 3 & Notas de 4 a 6 & Notas de 7 a 10 \\
\hline Agricultor & 37 & 27 & 36 \\
Pecuarista & 32 & 29 & 39 \\
Assistência técnica p/ agricultura & 67 & 26 & 7 \\
Assistência técnica p/ pecuária & 80 & 5 & 15 \\
Outra atividade & 52 & 25 & 23 \\
\hline Total da amostra & 47 & 25 & 28 \\
\hline
\end{tabular}

${ }^{1}$ Redação da questão: (27) "No meio agropecuário não adianta muito querer controlar tudo por escrito. O importante é o responsável estar presente na propriedade, pois assim já estaria efetuando os controles de forma visual, mas permanente".

Tabela 23. Identificação da freqüência percentual (\%) para alguns intervalos de notas atribuídos à questão $28^{1}$, segundo a atividade principal do entrevistado.

\begin{tabular}{lccc}
\hline \multicolumn{1}{c}{ Atividade principal } & Notas de 0 a 3 & Notas de 4 a 6 & Notas de 7 a 10 \\
\hline Agricultor & 32 & 31 & 37 \\
Pecuarista & 33 & 29 & 38 \\
Assistência técnica p/ agricultura & 60 & 20 & 20 \\
Assistência técnica p/ pecuária & 64 & 23 & 13 \\
Outra atividade & 42 & 33 & 25 \\
\hline Total da amostra & 41 & 30 & 29 \\
\hline
\end{tabular}

\footnotetext{
${ }^{1}$ Redação da questão: (28) "No meio agropecuário, as ordens de serviço que os produtores repassam aos funcionários devem ser bem claras e diretas, pois não adianta muito ficar trocando idéias com os funcionários".
} 


\subsubsection{Controle}

As questões 29 a 36 do questionário abordam temas relacionados a função administrativa controle. As questões relacionam-se ao controle da produção, das finanças, da comercialização e do pessoal.

O controle da área de produção é a principal atividade que os técnicos desempenham nas propriedades rurais. Essa prioridade é geralmente determinada pelo produtor rural, que busca na assistência técnica, conhecimento especializado sobre os sistemas de produção que conduzem em suas propriedades. A mediana 8 das respostas atribuídas pelos produtores a questão 29 apontam nessa direção, conforme mostram os dados da Tabela 24. A assertiva da questão 29 propõe que os técnicos se limitem a prestar orientação tecnológica às propriedades rurais, pois questões administrativas são responsabilidade do produtor rural. As medianas entre 3 e 4 atribuídas pelos técnicos a questão 29 demonstram parcial discordância (ou insatisfação) dos mesmos com essa situação, indicando que existe uma atitude favorável dos técnicos para ampliar sua atuação na propriedade. A opinião dos técnicos, no entanto, é significativamente diferente $(\mathrm{P}<0,05)$ em relação à opinião dos produtores sobre o assunto.

No controle da empresa agropecuária, um importante aspecto a ser considerado é o custo e o benefício das informações geradas pelo sistema de controle. A assertiva da questão 30 sugere que as propriedades rurais não adotam sistemas detalhados de controle, pela grande dificuldade de se coletar dados precisos (ou exatos) em nível de campo. Na pesquisa, essa assertiva foi aceita pela maioria dos produtores rurais e técnicos para a agricultura (medianas entre 7 e 8) e mostrou-se controversa para técnicos de pecuária (mediana 5), muito embora o teste da mediana não indicasse diferença de opinião entre os diferentes grupos. Já a assertiva da questão 32, sugere que as propriedades rurais não adotam sistemas detalhados de controle, por que esse trabalho não garante um aumento de rentabilidade. Na pesquisa, essa assertiva foi parcialmente recusada pela maioria dos produtores rurais (mediana 4) e fortemente recusada pelos 
técnicos (mediana 2), com diferença significativa de opinião sobre o assunto entre os técnicos e os produtores. Em conjunto, as respostas atribuídas às questões 30 e 32, parecem indicar que existe uma atitude favorável de técnicos e produtores na melhoria do sistema de informações gerenciais da propriedade rural, muito embora reconheçam a existência de dificuldades operacionais para a sua implantação, principalmente na agricultura. Dentre as dificuldades, mais aceitas e citadas por produtores e técnicos, para o controle da empresa agropecuária estão as restrições de habilidade e atitudes dos funcionários da fazenda. Essas dificuldades foram amplamente reconhecidas por produtores e técnicos, que atribuíram medianas entre 8 e 9, para as assertivas das questões 35 e 36, que sugeriam que os funcionários das propriedades rurais, não gostam, não sabem ou têm muitas dificuldades para fazer anotações por escrito sobre as tarefas realizadas.

Tabela 24. Mediana das respostas às questões 29, 30, 32, 35 e 36, segundo a atividade principal do entrevistado e o total da amostra.

\begin{tabular}{ccccccc}
\hline Questões & Agricultor & Pecuarista & $\begin{array}{c}\text { Técnicos p/ } \\
\text { agricultura }\end{array}$ & $\begin{array}{c}\text { Técnicos p/ } \\
\text { pecuária }\end{array}$ & $\begin{array}{c}\text { Outros } \\
\text { profissionais }\end{array}$ & $\begin{array}{c}\text { Total da } \\
\text { amostra }\end{array}$ \\
\hline 29 & $8(\mathrm{a})$ & $8(\mathrm{a})$ & $3(\mathrm{c})$ & $4(\mathrm{c})$ & $6(\mathrm{~b})$ & 7 \\
30 & $7(\mathrm{a})$ & $8(\mathrm{a})$ & $7(\mathrm{a})$ & $5(\mathrm{a})$ & $7(\mathrm{a})$ & 7 \\
32 & $4(\mathrm{a})$ & $4(\mathrm{a})$ & $2(\mathrm{~b})$ & $2(\mathrm{~b})$ & $3(\mathrm{a})$ & 3 \\
35 & $8(\mathrm{~b})$ & $9(\mathrm{a})$ & $9(\mathrm{ab})$ & $9(\mathrm{ab})$ & $8(\mathrm{~b})$ & 8 \\
36 & $8(\mathrm{a})$ & $8(\mathrm{a})$ & $8(\mathrm{a})$ & $8(\mathrm{a})$ & $8(\mathrm{a})$ & 8 \\
\hline
\end{tabular}

\footnotetext{
${ }^{1}$ Redação das questões: (29) "Se o profissional da assistência técnica prestar ao produtor uma boa orientação tecnológica, isso já é uma grande contribuição para a propriedade, pois questões administrativas são responsabilidade do produtor rural". (30) "As propriedades rurais, geralmente não adotam sistemas detalhados de controle de custos pela grande dificuldade de se coletar dados precisos (ou exatos) em nível de campo". (32) "As propriedades rurais, geralmente não adotam sistemas detalhados de controle porque esse trabalho não garante um aumento na rentabilidade". (35) "Os funcionários das propriedades rurais não gostam de fazer anotações por escrito sobre as tarefas realizadas". (36) "Os funcionários das propriedades rurais não sabem ou têm muitas dificuldades para fazer anotações por escrito sobre as tarefas realizadas".
} 
O grau de detalhamento do sistema de informações na empresa agropecuária é, em parte, abordado nas questões 31 e 33. Na assertiva da questão 31, sugere-se que alguns poucos indicadores de eficiência são suficientes para indicar se a propriedade está indo bem ou mal. Já a assertiva da questão 33, sugere que um sistema simplificado de controle pode ser suficiente para garantir uma boa administração, pois podem permitir uma noção sobre os resultados do empreendimento. Na pesquisa, a assertiva da questão 31 mostrou-se controversa, com medianas entre 4 e 5 para os técnicos e entre 5,5 e 6 para os produtores, conforme mostram os dados da Tabela 25. Já, a assertiva da questão 33 foi aceita pela maioria dos entrevistados, com mediana 8 para todos os sub-grupos pesquisados. Essas respostas, novamente parecem indicar a atitude favorável dos produtores rurais em investir em controles gerenciais mais detalhados, mas demonstram, também, sua insegurança com relação à dificuldade de manipular esses controles. Isso explica, em parte, porque muitos produtores rurais adquirem softwares de administração rural, mas, em seguida, não conseguem implantá-los e utilizá-los adequadamente nas propriedades rurais ${ }^{46}$. Deve existir, portanto, uma falsa impressão de que a informatização das propriedades rurais resolve facilmente muitas questões administrativas, o que não é verdade.

A questão 34 trata do controle da comercialização e sua assertiva sugere que, nas compras e vendas, o mais importante é controlar as quantidades, pois os preços são definidos pelo mercado. Nessa questão, mais uma vez constata-se diferenças na percepção de produtores e técnicos e entre a agricultura e a pecuária. As medianas dos produtores rurais (entre 6 e 7) foram maiores que a mediana dos técnicos (entre 4 e 5), o que pode indicar que os produtores, muitas vezes, desejam a implantação de determinados controles por questões de segurança (para evitar desvios), enquanto os técnicos consideram as tarefas de controles mais como uma fonte de informação gerencial, por isso, sua maior discordância com a assertiva 34, que sugere implicitamente que os preços não devam ser controlados. Na comparação da agricultura 
com a pecuária, novamente as respostas indicam que o processo de gestão deve considerar as características das empresas agropecuárias. Na questão 34, as medianas dos pecuaristas (7) e dos técnicos para a pecuária (5) superaram a dos agricultores (6) e técnicos para a agricultura (4), indicando que o controle de quantidade, principalmente da produção (no caso os estoques de animais) tem maior importância na pecuária do que na agricultura. $\mathrm{O}$ menor valor dos insumos pecuários relativamente aos agrícolas também, explicam em parte, a diferença de percepção entre os dois setores.

Tabela 25. Mediana das respostas às questões 31, 33 e 34, segundo a atividade principal do entrevistado e o total da amostra.

\begin{tabular}{ccccccc}
\hline Questões $^{1}$ & Agricultor & Pecuarista & $\begin{array}{c}\text { Técnicos p/ } \\
\text { agricultura }\end{array}$ & $\begin{array}{c}\text { Técnicos p/ } \\
\text { pecuária }\end{array}$ & $\begin{array}{c}\text { Outros } \\
\text { profissionais }\end{array}$ & $\begin{array}{c}\text { Total da } \\
\text { amostra }\end{array}$ \\
\hline 31 & $6(\mathrm{a})$ & $5,5(\mathrm{a})$ & $4(\mathrm{a})$ & $5(\mathrm{a})$ & $6(\mathrm{a})$ & 6 \\
33 & $8(\mathrm{a})$ & $8(\mathrm{a})$ & $8(\mathrm{a})$ & $8(\mathrm{a})$ & $8(\mathrm{a})$ & 8 \\
34 & $6(\mathrm{ab})$ & $7(\mathrm{a})$ & $4(\mathrm{c})$ & $5(\mathrm{~b})$ & $7(\mathrm{ab})$ & 6 \\
\hline
\end{tabular}

1 Redação das questões: (31) "Alguns poucos indicadores de eficiência (produtividade, índices zootécnicos, etc.) e de resultado (sobra de dinheiro em caixa, etc.) são suficientes para indicar se a propriedade está indo bem ou mal". (33) "É possível que um sistema de controle simplificado seja suficiente para garantir uma boa administração da propriedade rural, porque eles permitem, pelo menos, uma noção sobre os resultados técnicos e econômicos do empreendimento". (34) "Na compra dos insumos e na venda da produção, o mais importante é controlar as quantidades para evitar desvios, pois os preços são definidos pelo mercado".

De uma forma geral, os resultados quantitativos mostraram importantes diferenças na opinião e percepção de produtores e técnicos sobre temas relacionados à administração da empresa agropecuária. Em muitos casos, as diferenças são significativas ao nível de 5\% o que comprova uma baixa coorientação de atitudes entre produtores e técnicos no assunto em discussão. Por outro lado, as diferenças de opinião e

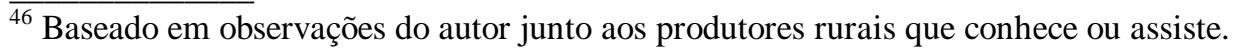


percepção entre agricultores e pecuaristas e entre técnicos de agricultura e técnicos de pecuária geralmente são pequenas e não significativas ao nível de 5\%. Os resultados obtidos certamente não esgotam o assunto da presente pesquisa, mas contribuem para uma melhor compreensão do amplo e complexo processo de se administrar uma empresa agropecuária e de se fazer recomendações administrativas a essas empresas. Não obstante, o capítulo seguinte apresenta algumas recomendações para a prática da administração rural. 


\section{RECOMENDAÇÕES PARA A PRÁTICA DA ADMINISTRAÇÃO RURAL}

Conforme indicado anteriormente no terceiro objetivo específico desse trabalho e nos argumentos utilizados para justificar o estudo do problema da pesquisa, esperava-se, ao final desse trabalho, poder propor formas alternativas que pudessem orientar a administração de empresas agropecuárias. Através de um "roteiro", esperavase poder contribuir, tanto para um processo de gestão mais eficiente das empresas agropecuárias por parte dos produtores rurais, como facilitar e melhorar a eficiência dos serviços de aconselhamento gerencial, que os técnicos precisam transmitir cotidianamente aos produtores. Neste sentido, e tendo em vista os resultados obtidos com essa pesquisa, passa-se a fazer recomendações para a prática da administração nas empresas agropecuárias.

Pretende-se no capítulo indicar, também, quais são as principais atividades administrativas desenvolvidas em empresas agropecuárias e, dentre elas, quais são as de maior relevância no âmbito de algumas empresas agropecuárias referenciais do meio rural brasileiro. Com a apresentação e discussão das principais atividades administrativas, pretende-se, também: (a) contribuir para uma melhor compreensão das principais técnicas de gestão apresentadas nos livros textos de administração rural; (b) contribuir para um melhor entendimento sobre a aplicabilidade prática dessas técnicas de gestão em empresas agropecuárias; e (c) estabelecer uma importância relativa para as principais técnicas de gestão em diferentes empresas agropecuárias, ou seja, identificar que tipos de atividades administrativas são mais ou menos relevantes para diferentes empresas agropecuárias referenciais. 
O capítulo está organizado em seis partes. Na primeira, descreve-se as características das empresas agropecuárias referenciais, que servirão de base para a discussão a ser desenvolvida e para as proposições a serem feitas. Na segunda, discutese a importância da gestão nas diferentes áreas administrativas (produção, finanças, comercialização e pessoal) dessas empresas. Nas quatro partes seguintes, pela ordem, discute-se sobre as relevâncias e limitações das funções administrativas de planejamento, organização, direção e controle nas empresas agropecuárias referenciais.

\subsection{As empresas agropecuárias referenciais}

A grande diversidade das empresas agropecuárias dificulta a generalização de recomendações administrativas a essas empresas. Procurando minimizar a dificuldade em se desenvolver uma discussão mais detalhada sobre as formas alternativas de gerência de empresas agropecuárias, optou-se, neste estudo, por idealizar algumas empresas agropecuárias referenciais para servirem de base para a discussão do assunto. Com essa opção, não se pretende realizar estudos de casos, mas, sim, idealizar cenários representativos de importantes sistemas de produção da agropecuária brasileira, de forma que a discussão sobre as formas de gerência possa ser extrapolada, pelo menos, para um determinado grupo de empresas agropecuárias com certas características em comum. Pretende-se, também, que a discussão de formas alternativas de gestão, para os sistemas de produção considerados nesse estudo, possa facilitar futuras discussões de outros sistemas de produção aqui não considerados.

Neste estudo, as empresas agropecuárias referenciais são hipotéticas, mas em sua idealização procurou-se representar características próximas às observadas no meio rural brasileiro. Dentre as características consideradas para a idealização das empresas agropecuárias referenciais pode-se citar: (1) a área ocupada pelas principais atividades e a área total da propriedade; (2) a participação dessas atividades na renda bruta total; (3) o destino principal da produção; (4) alguns indicadores sócio-econômicos 
da empresa e do empresário, tais como: a participação da mão-de-obra familiar e contratada no trabalho total, a percentagem da renda familiar proveniente da propriedade, o espírito empreendedor do empresário e o seu grau de aversão ao risco, entre outros. Ao todo foram idealizadas sete empresas agropecuárias referencias. As denominações e respectivas siglas utilizadas para a caracterização das empresas foram: Grãos (GR); Bovino de Corte (BC); Cana-de-açúcar (CA); Café (CF); Frango (FR); Hortifruti (HF) e Pequena Produção (PP).

As principais características de cada uma das empresas agropecuárias referenciais estão sintetizadas nos Quadros 2 a 5. O Quadro 2 mostra a área total de cada empresa e a área ocupada pelas principais atividades agrícolas e pecuárias ao longo de um ano. No Quadro 3 é apresentada a participação de cada atividade na renda bruta anual das empresas. O Quadro 4 identifica o destino principal da produção das empresas, segundo as principais atividades, e o Quadro 5 relaciona alguns indicadores socioeconômicos das empresas e dos respectivos empresários. As informações constantes nos Quadros 2 a 5, no entanto, não são rígidas no tempo e no espaço. Essas informações procuram apenas dar uma noção geral sobre as formas predominantes no tempo e no espaço, quanto à estrutura e o funcionamento das empresas agropecuárias referenciais. Aqui cabe ressaltar que as empresas referenciais "Grãos" e "Bovino de Corte" se assemelham às características da amostra pesquisada nos grupos focais e no questionário de campo. Neste sentido, a discussão a ser realizada nesta secção para essas empresas considera, apenas em parte, os resultados qualitativos e quantitativos descritos no capítulo 5. Para as demais ${ }^{47}$ empresas referenciais as proposições que serão apresentadas e discutidas não possuem evidências estatísticas e, portanto, sua comprovação depende de novos estudos.

\footnotetext{
$\overline{47}$ Aqui, vale lembrar, que os produtores e técnicos não vinculados à produção de grãos e a criação de bovinos de corte foram agrupados na alternativa "outra atividade principal" e seus dados não foram analisados individualmente.
} 
Quadro 2 - Ocupação do solo, em hectares, pelas principais atividades nas empresas agropecuárias referenciais.

\begin{tabular}{|c|c|c|c|c|c|c|c|}
\hline Atividades & $\begin{array}{l}\text { EMPRESA } \\
\text { GRÃOS }\end{array}$ & $\begin{array}{l}\text { EMPRESA } \\
\text { BOVINO } \\
\text { DE CORTE }\end{array}$ & \begin{tabular}{cl}
\multicolumn{2}{c}{ EMPRESA } \\
2 & CAN \\
& A-DE- \\
& AÇÚ \\
& CAR \\
\end{tabular} & $\begin{array}{l}\text { EMPRESA } \\
\text { CAFÉ }\end{array}$ & $\begin{array}{l}\text { EMPRESA } \\
\text { FRANGO }\end{array}$ & $\begin{array}{c}\text { EMPRESA } \\
\text { HORTIFRUTI }\end{array}$ & $\begin{array}{c}\text { EMPRESA } \\
\text { PEQUENA } \\
\text { PRODUÇÃO }\end{array}$ \\
\hline Soja & 200 & & & & & & \\
\hline Milho & 100 & & & 3 & 15 & & 3 \\
\hline Algodão & & & & & & & 1 \\
\hline Feijão & & & & & 5 & & 4 \\
\hline Trigo & 100 & & & & & & \\
\hline Milho safrinha & 100 & & & & & & 2 \\
\hline Aveia & 100 & & & & 20 & & 2 \\
\hline Café & & & & 35 & & & \\
\hline Cana-de-açúcar & & & 200 & 2 & & & \\
\hline Olericultura & & & & & & 5 & \\
\hline Fruticultura & & & & & & 10 & \\
\hline Bovinos de corte & & 1500 & & & & & \\
\hline Bovinos de Leite & & & & 10 & 3 & & 3 \\
\hline Frango & & & & & 2 & & \\
\hline Área c/ agricultura ${ }^{1}$ & 600 & 0 & 200 & 40 & 40 & 15 & 12 \\
\hline 2.1.1 Área c/ pecuária & 0 & 1500 & 0 & 10 & 5 & 0 & 3 \\
\hline Área total explorada $^{\top}$ & 600 & 1500 & 200 & 50 & 45 & 15 & 15 \\
\hline Área total propriedade & 330 & 2000 & 230 & 60 & 30 & 20 & 10 \\
\hline
\end{tabular}

\footnotetext{
${ }^{1}$ inclui lavouras de verão e inverno
} 
Quadro 3 - Participação percentual das principais atividades na formação da renda bruta anual nas empresas agropecuárias referenciais

\begin{tabular}{|c|c|c|c|c|c|c|c|}
\hline \multirow[t]{2}{*}{ Atividades } & \multirow{2}{*}{$\begin{array}{c}\text { EMPRESA } \\
\text { GRÃOS }\end{array}$} & EMPRESA & EMPRESA & \multirow{2}{*}{$\begin{array}{l}\text { EMPRESA } \\
\text { CAFÉ }\end{array}$} & \multirow{2}{*}{$\begin{array}{l}\text { EMPRESA } \\
\text { FRANGO }\end{array}$} & \multirow{2}{*}{$\begin{array}{c}\text { EMPRESA } \\
\text { HORTIFRUTI }\end{array}$} & \multirow{2}{*}{$\begin{array}{c}\text { EMPRESA } \\
\text { PEQUENA } \\
\text { PRODUÇÃO }\end{array}$} \\
\hline & & $\begin{array}{ll}3 \quad \text { BOVIN } \\
\text { O } \\
\text { DE } \text { CORTE }\end{array}$ & \begin{tabular}{|ll}
4 & CAN \\
& A-DE- \\
& AÇÚ \\
& CAR \\
\end{tabular} & & & & \\
\hline Soja & 50 & & & & & & \\
\hline Milho & 20 & & & 3 & 5 & & 20 \\
\hline Algodão & & & & & & & 10 \\
\hline Feijão & & & & & 5 & & 30 \\
\hline Trigo & 15 & & & & & & \\
\hline Milho safrinha & 10 & & & & & & 10 \\
\hline Aveia & 5 & & & & 5 & & 5 \\
\hline Café & & & & 70 & & & \\
\hline Cana-de-açúcar & & & 100 & 2 & & & \\
\hline Olericultura & & & & & & 50 & \\
\hline Fruticultura & & & & & & 50 & \\
\hline Bovinos de corte & & 100 & & & & & \\
\hline Bovinos de Leite & & & & 25 & 20 & & 25 \\
\hline Frango & & & & & 65 & & \\
\hline & & & & & & & \\
\hline Renda c/ agricultura (\%) & 100 & 0 & 100 & 75 & 15 & 100 & 75 \\
\hline Renda c/ pecuária (\%) & 0 & 100 & 0 & 25 & 85 & 0 & 25 \\
\hline Renda total $(\%)$ & 100 & 100 & 100 & 100 & 100 & 100 & 100 \\
\hline
\end{tabular}


Quadro 4 - Destino principal da produção nas empresas agropecuárias referenciais, segundo as principais atividades.

\begin{tabular}{|c|c|c|c|c|c|c|c|}
\hline $\begin{array}{r}4.1 \quad \text { Ativida } \\
\text { des }\end{array}$ & $\begin{array}{l}\text { EMPRESA } \\
\text { GRÃOS }\end{array}$ & $\begin{array}{c}\text { EMPRESA } \\
\text { BOVINO } \\
\text { DE CORTE }\end{array}$ & \begin{tabular}{|ll|}
\multicolumn{2}{|c|}{ EMPRESA } \\
$\mathbf{5}$ & CAN \\
& A-DE- \\
& AÇÚ \\
& CAR \\
\end{tabular} & $\begin{array}{l}\text { EMPRESA } \\
\text { CAFÉ }\end{array}$ & $\begin{array}{l}\text { EMPRESA } \\
\text { FRANGO }\end{array}$ & $\begin{array}{c}\text { EMPRESA } \\
\text { HORTIFRUTI }\end{array}$ & $\begin{array}{c}\text { EMPRESA } \\
\text { PEQUENA PRODUÇÃO }\end{array}$ \\
\hline Soja & $\begin{array}{c}\text { cooperativas e } \\
\text { tradings }\end{array}$ & & & & & & \\
\hline Milho & $\begin{array}{l}\text { cooperativas e } \\
\text { tradings }\end{array}$ & & & $\begin{array}{c}\text { consumo } \\
\text { interno (leite) }\end{array}$ & $\begin{array}{c}\text { consumo interno } \\
\text { (frango e leite) }\end{array}$ & & $\begin{array}{c}\text { comércio local e consumo } \\
\text { interno (leite) }\end{array}$ \\
\hline Algodão & & & & & & & comércio local \\
\hline Feijão & & & & & Comerciantes locais & & $\begin{array}{c}\text { comércio local e consumo } \\
\text { interno }\end{array}$ \\
\hline Trigo & cooperativas & & & & & & \\
\hline Milho safrinha & $\begin{array}{c}\text { cooperativas e } \\
\text { tradings }\end{array}$ & & & & & & $\begin{array}{c}\text { comércio local e consumo } \\
\text { interno (leite) }\end{array}$ \\
\hline Aveia & $\begin{array}{c}\text { (consumo interno) } \\
\text { cobertura vegetal }\end{array}$ & & & & $\begin{array}{c}\text { consumo interno } \\
\text { (leite) }\end{array}$ & & consumo interno (leite) \\
\hline Café & & & & $\begin{array}{l}\text { Cooperativas e } \\
\text { tradings }\end{array}$ & & & \\
\hline Cana-de-açúcar & & & $\begin{array}{c}\text { usina } \\
\text { integrada }\end{array}$ & $\begin{array}{c}\text { consumo } \\
\text { interno (leite) }\end{array}$ & & & \\
\hline Olericultura & & & & & & $\begin{array}{c}\text { Atacadistas, } \\
\text { varejistas e } \\
\text { consumidores } \\
\text { finais }\end{array}$ & \\
\hline Fruticultura & & & & & & $\begin{array}{c}\text { atacadistas, } \\
\text { varejistas e } \\
\text { consumidores } \\
\text { finais }\end{array}$ & \\
\hline Bovinos de corte & & $\begin{array}{c}\text { frigoríficos e outros } \\
\text { pecuaristas }\end{array}$ & & & & & \\
\hline Bovinos de Leite & & & & $\begin{array}{l}\text { cooperativas } \\
\text { ou usinas }\end{array}$ & $\begin{array}{c}\text { cooperativas ou } \\
\text { usinas }\end{array}$ & & cooperativas ou usinas \\
\hline Frango & & & & & indústria integrada & & \\
\hline
\end{tabular}


Quadro 5 - Relação de alguns indicadores socioeconômicos nas empresas agropecuárias referenciais.

\begin{tabular}{|c|c|c|c|c|c|c|c|}
\hline \multirow[t]{2}{*}{ Indicadores socioeconômicos } & \multirow{2}{*}{$\begin{array}{l}\text { EMPRESA } \\
\text { GRÃOS }\end{array}$} & \multirow{2}{*}{$\begin{array}{c}\text { EMPRESA } \\
\text { BOVINO DE } \\
\text { CORTE }\end{array}$} & EMPRESA & \multirow{2}{*}{$\begin{array}{l}\text { EMPRESA } \\
\text { CAFÉ }\end{array}$} & \multirow{2}{*}{$\begin{array}{l}\text { EMPRESA } \\
\text { FRANGO }\end{array}$} & \multirow{2}{*}{$\begin{array}{c}\text { EMPRESA } \\
\text { HORTIFRUTI }\end{array}$} & \multirow{2}{*}{$\begin{array}{c}\text { EMPRESA } \\
\text { PEQUENA } \\
\text { PRODUÇÃO }\end{array}$} \\
\hline & & & $6 \begin{array}{l}\text { CANA- } \\
\text { DE- } \\
\text { AÇÚC } \\
\text { AR }\end{array}$ & & & & \\
\hline 1-) Região/Estado de referência & Paraná & $\begin{array}{l}\text { Mato Grosso } \\
\text { do Sul }\end{array}$ & São Paulo & Minas Gerais & $\begin{array}{c}\text { Santa } \\
\text { Catarina }\end{array}$ & Vários & Vários \\
\hline 2-) Local da residência familiar & Urbana & Urbana & Urbana & Rural & Rural & Urbana & Rural \\
\hline $\begin{array}{l}\text { 3-) Percentagem (\%) da renda familiar } \\
\text { proveniente da propriedade. }\end{array}$ & 90 & 70 & 60 & 100 & 100 & 80 & 100 \\
\hline \multicolumn{8}{|l|}{$\begin{array}{lll}\text { 4-) Participação da mão-de-obra no } \\
\text { trabalho total (em \%) }\end{array}$} \\
\hline$\bullet \quad$ Mão-de-obra fixa familiar & 30 & 10 & 5 & 35 & 50 & 20 & 70 \\
\hline - $\quad$ Mão-de-obra fixa contratada & 60 & 70 & 5 & 30 & 40 & 50 & 20 \\
\hline$\bullet \quad$ Mão-de-obra temporária & 10 & 20 & 90 & 35 & 10 & 30 & 10 \\
\hline $\begin{array}{l}\text { 5-) Vende freqüentemente serviços } \\
\text { manuais a terceiros? }\end{array}$ & Não & Não & Não & Não & Não & Não & Sim \\
\hline $\begin{array}{l}\text { 6-) Vende freqüentemente serviços } \\
\text { mecanizados a terceiros? }\end{array}$ & Sim & Não & Não & Não & Não & Não & Não \\
\hline $\begin{array}{l}\text { 7-) Compra freqüentemente serviços } \\
\text { mecanizados de terceiros? }\end{array}$ & Sim & Não & Sim & Não & Sim & Não & Sim \\
\hline $\begin{array}{l}\text { 8-) Arrenda freqüentemente terras de } \\
\text { terceiros? }\end{array}$ & Sim & Não & Não & Não & Não & Não & Não \\
\hline $\begin{array}{l}\text { 9-) Arrenda freqüentemente terras para } \\
\text { terceiros? }\end{array}$ & Não & Não & Sim & Não & Não & Não & Não \\
\hline $\begin{array}{l}\text { 10-) Possui distinção de marca e } \\
\text { qualidade da sua produção? }\end{array}$ & Não & Não & Não & Em parte & Não & Sim & Não \\
\hline 11-) Origem da posse da terra. & $\begin{array}{c}\text { Herança e } \\
\text { novas } \\
\text { compras } \\
\end{array}$ & Herança & Herança & Herança & Herança & Compra & Herança \\
\hline $\begin{array}{l}\text { 12-) Evolução da renda líquida da } \\
\text { propriedade. }\end{array}$ & $\begin{array}{l}\text { Estável ou } \\
\text { Crescente }\end{array}$ & Estável & $\begin{array}{l}\text { Estável ou } \\
\text { decrescente }\end{array}$ & $\begin{array}{l}\text { Estável ou } \\
\text { crescente }\end{array}$ & Estável & $\begin{array}{l}\text { Estável ou } \\
\text { crescente }\end{array}$ & $\begin{array}{l}\text { Estável ou } \\
\text { decrescente }\end{array}$ \\
\hline
\end{tabular}


Quadro 5 - Relação de alguns indicadores socioeconômicos nas empresas agropecuárias referenciais.

\begin{tabular}{|c|c|c|c|c|c|c|c|}
\hline \multirow[t]{2}{*}{ Indicadores socioeconômicos } & \multirow{2}{*}{$\begin{array}{l}\text { EMPRESA } \\
\text { GRÃOS }\end{array}$} & \multirow{2}{*}{$\begin{array}{c}\text { EMPRESA } \\
\text { BOVINO DE } \\
\text { CORTE }\end{array}$} & EMPRESA & \multirow{2}{*}{$\begin{array}{l}\text { EMPRESA } \\
\text { CAFÉ }\end{array}$} & \multirow{2}{*}{$\begin{array}{l}\text { EMPRESA } \\
\text { FRANGO }\end{array}$} & \multirow{2}{*}{$\begin{array}{c}\text { EMPRESA } \\
\text { HORTIFRUTI }\end{array}$} & \multirow{2}{*}{$\begin{array}{c}\text { EMPRESA } \\
\text { PEQUENA } \\
\text { PRODUÇÃO }\end{array}$} \\
\hline & & & $\begin{array}{ll}7 & \text { CANA- } \\
\text { DE- } & \\
\text { AÇÚC } & \\
\text { AR }\end{array}$ & & & & \\
\hline 13-) Fases do ciclo de vida da empresa. & $\begin{array}{c}\text { Crescimento } \\
\text { ou } \\
\text { estabilidade }\end{array}$ & $\begin{array}{l}\text { Estabilidade } \\
\text { ou velhice }\end{array}$ & $\begin{array}{l}\text { Estabilidade } \\
\text { ou velhice }\end{array}$ & $\begin{array}{c}\text { Crescimento } \\
\text { ou } \\
\text { estabilidade }\end{array}$ & Estabilidade & $\begin{array}{l}\text { Infância ou } \\
\text { crescimento }\end{array}$ & $\begin{array}{l}\text { Estabilidade ou } \\
\text { velhice }\end{array}$ \\
\hline 14-) Estratégia empresarial & Crescimento & Manutenção & Manutenção & Crescimento & Manutenção & Crescimento & Sobrevivência \\
\hline 15-) Evolução dos gastos familiares. & Crescente & Crescente & Crescente & Estável & Estável & Crescente & Estável \\
\hline 16-) Grau de instrução do proprietário. & $2^{\circ}$ grau & Superior & Superior & $1^{\circ}$ grau & $1^{\circ}$ grau & Superior & $1^{\circ}$ grau \\
\hline $\begin{array}{l}\text { 17-) Membros da família que trabalham } \\
\text { na propriedade. }\end{array}$ & $\begin{array}{l}\text { Pai e filhos } \\
\text { homens }\end{array}$ & $\begin{array}{l}\text { Pai e filhos } \\
\text { homens }\end{array}$ & Pai & $\begin{array}{r}\text { Toda a } \\
\text { família }\end{array}$ & $\begin{array}{l}\text { Toda a } \\
\text { família }\end{array}$ & Toda a família & Toda a família \\
\hline 18-) Aversão ao risco do empresário. & $\begin{array}{l}\text { Baixa a } \\
\text { média }\end{array}$ & Média a alta & Média a alta & Média a alta & Média a alta & Baixa a média & Média a alta \\
\hline 19-) Idade do empresário. & 30 a 50 anos & 40 a 60 anos & 50 a 70 anos & 40 a 60 anos & 40 a 60 anos & $\begin{array}{c}20 \text { a } 40 \\
\text { anos }\end{array}$ & $\begin{array}{l}50 \text { a } 70 \\
\text { anos }\end{array}$ \\
\hline $\begin{array}{l}\text { 20-) Dificuldades na sucessão } \\
\text { patrimonial }\end{array}$ & Média & $\begin{array}{l}\text { Baixa a } \\
\text { média }\end{array}$ & Média & Média a alta & $\begin{array}{l}\text { Baixa a } \\
\text { média }\end{array}$ & $\begin{array}{l}\text { Média a } \\
\text { Alta }\end{array}$ & Média \\
\hline $\begin{array}{lll}21-) & \text { Espírito } & \text { empreendedor } \\
\text { empresário } & & \\
\end{array}$ & Médio a alto & $\begin{array}{l}\text { Baixo a } \\
\text { médio }\end{array}$ & $\begin{array}{l}\text { Baixo a } \\
\text { médio }\end{array}$ & Médio a alto & $\begin{array}{l}\text { Baixo a } \\
\text { médio }\end{array}$ & Médio a alto & Baixo a médio \\
\hline $\begin{array}{l}\text { 22-) Gosto por atividades administrativas } \\
\text { na empresa. }\end{array}$ & Baixo & $\begin{array}{l}\text { Baixo a } \\
\text { médio }\end{array}$ & Médio & Baixo & Baixo & Médio & Baixo \\
\hline
\end{tabular}




\subsubsection{Empresa referencial "Grãos" (GR).}

A empresa referencial denominada Grãos explora principalmente as atividades de soja, milho, trigo e aveia. Sua localização de referência é o Estado do Paraná. A empresa possui uma área total de terras próprias de 330 hectares. Dessa extensão total, cerca de 300 hectares são cultivados duas vezes ao ano, perfazendo uma área anual explorada de 600 hectares de lavouras, sendo 300 hectares na safra de verão e 300 hectares na safra de inverno. Na safra de verão, normalmente dois terços da área total, cerca de 200 hectares, são cultivados com soja e um terço, ou o equivalente a 100 hectares, são cultivados com milho. Na safra de inverno, o trigo ocupa uma área de aproximadamente 100 hectares (um terço do total), o "milho safrinha" ou "milho de segunda safra" ocupa outros 100 hectares e, outras culturas anuais de inverno (como a aveia, por exemplo) ocupam os 100 hectares restantes.

Ao longo dos anos, no entanto, ocorrem alterações na proporção das áreas ocupadas pelas culturas mencionadas ou a introdução eventual de outras culturas, tanto na safra de verão como na safra de inverno. Dentre os motivos principais que alteram as proporções das áreas cultivadas ao longo dos anos, pode-se citar: (a) a situação presente e as perspectivas de preços de mercado para os produtos; (b) a evolução dos custos de produção e as perspectivas de rentabilidade das culturas em cada ano safra; (c) os incentivos ou desestímulos, proporcionados pelas normas do crédito rural para as culturas, em cada ano safra; (d) o plano de rotação de culturas adotado pela empresa; (e) a possibilidade de aproveitamento de parte das máquinas e implementos em mais de uma cultura; (f) os resultados físicos (produtividade) e financeiros (rentabilidade) obtidos em anos anteriores; (g) os gostos e preferências do produtor, entre outros. Além disso, vale ressaltar que o sistema de cultivo adotado na empresa Grãos é o plantio direto e a tecnologia utilizada na condução das lavouras é aquela recomendada pela pesquisa agronômica, resultando em altos índices de produtividade da terra. Nessa empresa, há uma incessante busca por novas tecnologias de produção, visando ampliar a produtividade da terra. 
De uma forma geral, os produtos soja, milho e milho safrinha são comercializados através de cooperativas ou vendidos a outras empresas privadas que atuam na região da propriedade, como agroindústrias ou empresas de comercialização de grãos. No caso do trigo a venda da produção é feita, geralmente, através de cooperativas, que o revende aos moinhos de trigo ao longo do ano. A aveia, por sua vez, geralmente é cultivada visando a cobertura do solo, por ser essa, uma técnica importante para o sistema de plantio direto e para o plano de rotação de culturas adotado na empresa. Eventualmente, parte da produção de aveia é comercializada e parte guardada para semente. Em todos as atividades não há distinção de marca e qualidade da produção, tornando o produtor rural um tomador de preços de venda no mercado.

$\mathrm{Na}$ formação ou composição da renda bruta anual, a soja normalmente responde por metade do valor total, seguida pelo milho com $20 \%$, trigo $15 \%$, milho safrinha $10 \%$ e outras lavouras de inverno com $5 \%$. Nessa empresa, grande parte da renda familiar é proveniente da propriedade rural, pois o produtor, mesmo morando na cidade, quase sempre trabalha em tempo integral na propriedade. $\mathrm{O}$ mesmo não ocorre com outros membros da família, principalmente a mulher e as filhas maiores, que trabalham em empresas urbanas.

Na empresa referencial Grãos a mão-de-obra contratada é predominante, se considerado o tempo total de trabalho. A mão-de-obra contratada é, em sua maioria, composta por empregados permanentes. Nessa empresa, a mão-de-obra temporária é geralmente contratada para auxiliar em serviços operacionais de plantio, capina e colheita, ou em outras situações extraordinárias onde há picos de necessidade adicional de mão-de-obra. A mão-de-obra familiar, embora se envolva também com os serviços operacionais, geralmente é a responsável por todas as decisões estratégicas da empresa Grãos. Isso, às vezes, acaba sobrecarregando o trabalho do produtor rural e concentrando seus esforços na área de produção, relativamente ao tempo despendido às áreas de finanças, comercialização e de recursos humanos. Dos membros da família, o pai e os 
filhos maiores, normalmente, são os que comandam a propriedade. Nessa empresa, os tomadores de decisão geralmente possuem um médio a alto espírito empreendedor, e uma baixa a média aversão ao risco.

A eficiência técnica e econômica no uso do maquinário é um fator importante para o sucesso da empresa referencial Grãos. Nessa empresa, como parte substancial do custo fixo (depreciações e custos de oportunidade) está relacionada à eficiência no uso do maquinário disponível, questões de logística e monitoramento de custos na área de mecanização assumem fundamental importância. Isso a induz, freqüientemente, a comprar de terceiros e/ou vender para terceiros determinados serviços mecanizados, necessários à condução das lavouras. Também é comum a troca de horas de serviços mecanizados com produtores vizinhos. A economia de escala no uso do maquinário, também pode induzir a empresa a arrendar terras de terceiros, visando diluir os custos da infraestrutura de máquinas e implementos existentes na propriedade.

Outros parâmetros importantes para o sucesso da empresa Grãos, mas às vezes não tratado adequadamente pelo produtor rural, são o nível das despesas familiares e o fluxo de caixa da propriedade. No primeiro caso, o problema está relacionado aos crescentes desembolsos necessários para manter o padrão de vida urbano da família. Isso tem ampliado as retiradas líquidas de dinheiro da propriedade rural pela família e comprometido, por conseqüência, a capacidade de investimentos na propriedade. No segundo caso, a constante necessidade de contratação de capital de giro junto a terceiros tem reduzido o índice de liquidez imediata da empresa ao longo do tempo e dificultado a gestão financeira e comercial da empresa. Como as atividades conduzidas nesse tipo de empresa exigem altos desembolsos para a implantação e condução das lavouras e, a receita é normalmente instável entre anos, pelas oscilações da produtividade e preços, a gestão da área de finanças e de comercialização também assume fundamental importância. 
As primeiras colunas dos quadros 2 a 5 sintetizam algumas informações sobre a empresa referencial Grãos. A discussão sobre os problemas levantados nesta seção e a recomendação de formas alternativas de gestão, para a empresa referencial Grãos, será feita adiante nos itens 6.2 a 6.6.

\subsubsection{Empresa referencial "Bovino de Corte" (BC).}

$\mathrm{Na}$ empresa referencial denominada Bovino de Corte a única atividade econômica significativa é a bovinocultura de corte. Sua localização de referência é o Estado do Mato Grosso do Sul. A área total de terras da propriedade é de aproximadamente 2.000 hectares. Desse total, cerca de 1.500 hectares são ocupados com pastagens perenes cultivadas, sendo a área restante constituída por áreas de reserva legal, inaproveitáveis e destinada a outros fins, para atividades de menor relevância econômica.

Na empresa referencial Bovino de Corte predomina o sistema misto de produção pecuária, que envolve as fases de cria, recria e engorda de bovinos da raça nelore. A participação dessas diferentes fases de criação dos bovinos (cria, recria e engorda) na formação da receita e da renda bruta anual varia no tempo e no espaço. A evolução do número de cabeças no rebanho total também não segue um padrão estável ou linear ao longo do tempo, pois a comercialização (compra e venda) das diferentes categorias animais, que compõem o rebanho, é influenciada por uma série de fatores independentes. Isso pode ocorrer, por exemplo, pelas seguintes razões: (1) o nível dos preços de mercado dos bovinos afeta o número de animais comercializados (compras e vendas) ao longo do tempo; (2) a paridade ou relação dos preços de mercado entre as diferentes categorias animais afeta a definição da categoria animal a ser comercializada; (3) as condições climáticas afetam o desenvolvimento vegetativo das pastagens e o desempenho produtivo do rebanho, fazendo variar a comercialização do número de animais, em cada categoria animal do rebanho; (4) o valor dos investimentos realizados 
na propriedade e as variações nos gastos familiares também afetam o volume comercializado de animais ao longo do tempo.

De uma forma geral, a venda dos animais que atingem peso de abate é feita diretamente a frigoríficos da região e, a venda dos demais animais (para reprodução, recria e engorda) é feita, alternativamente, através de leilões regionais, para intermediários (facilitadores de negócios) ou diretamente a outros produtores. $\mathrm{Na}$ comercialização é freqüiente o surgimento de condutas oportunistas por parte dos agentes de mercado, exigindo grande atenção e habilidade do produtor na condução e realização dos negócios. Dentre as principais dificuldades na comercialização dos bovinos decorrentes da prática de condutas oportunistas, pode-se destacar: (a) possibilidades de inadimplências ou atraso de pagamentos por parte dos agentes de mercado; (b) falta de padronização, nos lotes de animais comercializados, quanto à raça, peso, idade e outras características de fenótipo e genótipo dos animais. Isso dificulta a avaliação econômica dos lotes e exige a presença física de compradores e vendedores para a concretização de negócios. (c) alta carga tributária na comercialização e elevado nível de sonegação fiscal.

No aspecto produtivo do rebanho predomina a criação extensiva e de média a baixa eficiência zootécnica. Na empresa referencial Bovino de Corte, a produtividade normalmente obtida é superior a média nacional, mas os níveis de produtividade do rebanho e da terra são, quase sempre, inferiores aos níveis possíveis de serem atingidos com o uso integral da tecnologia recomendada pela pesquisa. $\mathrm{O}$ baixo nível de adoção tecnológica pode, por exemplo, ser identificado através dos seguintes índices de eficiência: baixa taxa de natalidade; alta taxa de mortalidade; baixa capacidade de lotação das pastagens; pequeno ganho de peso dos animais na estação seca; longo período entre partos das matrizes; elevada idade de abate dos animais; entre outros. A baixa eficiência produtiva é, portanto, o principal fator limitante para o crescimento e o desenvolvimento da empresa referencial Bovino de Corte. 
Na empresa referencial Bovino de Corte, a mão-de-obra contratada é predominante e, em sua maioria, composta por empregados permanentes. Nessa empresa, a mão-de-obra temporária é pouco utilizada, à exceção de serviços de empreita, por exemplo, para a construção e reforma de cercas e outras benfeitorias, roçada manual de pastagens, entre outras. A mão-de-obra familiar, que reside na cidade e pode ter outras ocupações profissionais, se envolve pouco com os serviços operacionais de produção, mas é a responsável por todas as decisões estratégicas da empresa. Dos membros da família, o pai e os filhos maiores, normalmente, são os que comandam a propriedade. Nessa empresa, geralmente, os tomadores de decisão possuem um baixo ou médio espírito empreendedor, e uma média ou alta aversão ao risco.

Devido ao caráter extensivo da produção e ao alto investimento na formação do rebanho e da infraestrutura (pastagens e benfeitorias) da propriedade, normalmente os custos fixos representam a maior parte do custo total de produção do empreendimento. Nesse aspecto, merece destaque o valor correspondente à depreciação das pastagens e o custo de oportunidade do capital investido em terras, pastagens e no rebanho. A alta liquidez do rebanho (facilidade de transformá-lo em dinheiro a qualquer momento) e a complexidade de sua dinâmica (valor diferenciado das categorias animais), também tornam importantes para o sucesso dessa empresa as decisões estratégicas de comercialização e de investimentos.

As segundas colunas dos Quadros 2 a 5 sintetizam algumas informações sobre a empresa referencial Bovino de Corte. A discussão sobre os problemas levantados nesta seção e a recomendação de formas alternativas de gestão, para a empresa referencial Bovino de Corte, será feita adiante nos itens 6.2 a 6.6. 


\subsubsection{Empresa referencial "Cana-de-açúcar" (CA).}

Na empresa referencial denominada Cana-de-açúcar a única atividade econômica significativa é a cultura da cana-de-açúcar. Sua localização de referência é o Estado de São Paulo. A área total de terras da propriedade é de 230 hectares, sendo que, desse total, 200 hectares são ocupados por canaviais de várias idades. O ciclo de produção do canavial é de 5 a 6 anos, sendo que a cada 2 ou 3 anos uma parte das lavouras é reformada, iniciando um novo ciclo de produção do canavial.

A totalidade da produção é entregue anualmente, mediante contrato, a uma única empresa (usina de açúcar e álcool) da região. $\mathrm{O}$ valor recebido pela produção é função da qualidade da matéria-prima (teor de açúcares totais recuperáveis - ATR) e do preço médio dos produtos finais (açúcar e álcool), que é definido por um conselho estadual formado por representantes dos produtores e da indústria: o Consecana Conselho dos produtores de cana, açúcar e álcool. Ao longo do ano safra, a empresa recebe alguns adiantamentos pela cana entregue à usina e, ao final do período, recebe a diferença entre os adiantamentos e o preço final da matéria prima definido pelo contrato, segundo os padrões estabelecidos pelo Consecana.

$\mathrm{Na}$ condução dos canaviais, várias operações manuais e mecânicas são contratadas junto à usina. Dentre elas destaca-se: operações mecânicas de preparo do solo para a reforma do canavial, colheita manual ou mecânica do canavial, transporte da produção da lavoura à usina, etc. As mudas de cana-de-açúcar para a reforma dos canaviais também são fornecidas pela usina, além da assistência técnica e de alguns outros insumos. Dessa forma, na empresa referencial Cana-de-açúcar a mão-de-obra contratada de forma temporária responde pela quase totalidade do tempo total de trabalho. Nessa empresa, a mão-de-obra permanente realiza apenas algumas operações manuais e mecânicas não realizadas pela usina, como capina, aplicação de fertilizantes e defensivos, entre outras. Devido ao sistema integrado de produção e comercialização e do fácil manejo produtivo da cana-de-açúcar relativamente a outras atividades 
agropecuárias, a mão-de-obra familiar nessa empresa, normalmente, tem pouco envolvimento operacional e estratégico com a atividade, induzindo o produtor rural a manter atividades profissionais fora da propriedade. Além disso, a baixa possibilidade de se vender a produção para clientes alternativos, tendo em vista o alto custo de transporte da cana-de-açúcar, torna comum nesse setor agropecuário o arrendamento total das terras à usina integradora.

As terceiras colunas dos Quadros 2 a 5 sintetizam algumas informações sobre a empresa referencial Cana-de-açúcar. A discussão sobre os problemas levantados nesta seção e a recomendação de formas alternativas de gestão, para a empresa referencial Cana-de-açúcar, será feita adiante nos itens 6.2 a 6.6.

\subsubsection{Empresa referencial "Café" (CF).}

$\mathrm{Na}$ empresa referencial denominada Café mais de dois terços da renda bruta anual provém da comercialização do café. Sua localização de referência é o Estado de Minas Gerais. As terras da empresa possuem relevo ondulado ou fortemente ondulado, mas características físicas e químicas do solo, além do clima favorável, resultam em condições bastante adequadas e propícias ao cultivo do cafeeiro. $\mathrm{O}$ comércio do café na região é intenso e a empresa produz cafés de qualidade superior à média nacional.

$\mathrm{Na}$ empresa referencial Café, toda a mão-de-obra familiar reside e trabalha em tempo integral na propriedade. Visando principalmente uma melhor racionalidade no uso do fator trabalho a empresa se dedica também à exploração da bovinocultura de leite, que participa com cerca de um quarto da renda bruta anual da empresa. A atividade leite, embora conduzida com menor eficiência técnica e apresentando menor lucratividade relativamente ao café, contribui também para a geração de receitas mensais destinadas principalmente à manutenção familiar e, para 
ocupar as áreas de terras marginais às lavouras de café. Próximo à residência da família e, às instalações da pecuária de leite, a empresa explora, ainda, uma pequena área com as culturas de cana-de-açúcar e milho, que são destinadas à alimentação do rebanho leiteiro.

A área total da empresa é de 60 hectares, sendo que dessa extensão, 35 hectares são cultivados com café, 10 hectares são ocupados com pastagens perenes e 5 hectares são destinados à produção de milho e cana-de-açúcar. Os 10 hectares restantes compõem áreas de reserva legal, inaproveitáveis, com benfeitorias e destinadas a outros usos de menor relevância econômica.

A composição da mão-de-obra na empresa referencial Café mostra um certo equilíbrio entre a mão-de-obra permanente contratada, a mão-de-obra temporária contratada e a mão-de-obra familiar. Nos serviços operacionais de produção, as tarefas dos funcionários e dos membros da família são distribuídas no dia-a-dia pelo produtor rural, conforme a necessidade de trabalho em cada atividade. $\mathrm{Na}$ época de colheita do café concentra-se a contratação de mão-de-obra temporária. Todos os membros da família realizam serviços operacionais e opinam sobre as decisões estratégicas. A empresa recebe assistência técnica privada na atividade café e pública na atividade leite. Há dificuldades de compreensão, devido ao baixo grau de instrução formal do produtor, para a execução de algumas atividades administrativas nas áreas de finanças e comercialização. Nessa empresa, os tomadores de decisão geralmente possuem um médio a alto espírito empreendedor, mas, em contrapartida, uma média a alta aversão ao risco.

As quartas colunas dos Quadros 2 a 5 sintetizam algumas informações sobre a empresa referencial Grãos. A discussão sobre os problemas levantados nesta seção e a recomendação de formas alternativas de gestão, para a empresa referencial Café, será feita adiante nos itens 6.2 a 6.6. 


\subsubsection{Empresa referencial "Frango" (FR).}

$\mathrm{Na}$ empresa referencial denominada Frango a atividade econômica mais significativa é a avicultura de corte, que responde por cerca de dois terços da renda bruta anual da empresa. A segunda atividade mais importante é a bovinocultura de leite, que responde por aproximadamente $20 \%$ da renda bruta anual. Completam a formação da renda bruta anual nessa empresa as atividades feijão, milho e aveia que respondem, em conjunto, pelos $15 \%$ restantes.

A área total de terras da propriedade é de 30 hectares, sendo que, desse total, 20 hectares são ocupados por atividades agrícolas, principalmente pelas culturas de milho e feijão durante a safra de verão, e pela aveia durante a safra de inverno. As atividades pecuárias, principalmente a bovinocultura de leite (com áreas de pastagens perenes) e os galpões de criação de frangos ocupam cerca de 5 hectares da propriedade. O restante da área, em torno de 5 hectares, é composta por áreas inaproveitáveis, reserva legal, ocupada por moradias e destinadas a outros usos de menor relevância econômica. A localização de referência da empresa é o Estado de Santa Catarina.

No caso da avicultura, o sistema de produção adotado na propriedade é integrado à indústria, com todos os lotes de frango sendo destinados a um abatedouro de aves que atua na região. No caso do leite, a produção é destinada a um laticínio da região, que paga mensalmente pela produção entregue nos trinta dias anteriores. No caso do milho, parte da produção é consumida diretamente na propriedade (pelas atividades frango e leite) e parte destina-se a fábrica de ração vinculada ao abatedouro de aves. A produção de feijão normalmente é vendida a comerciantes ou cooperativas da região, enquanto a produção de aveia destina-se principalmente à alimentação do gado de leite.

No sistema integrado de produção de frangos de corte, o produtor limitase à realização das tarefas diárias de condução da granja como, por exemplo, o trato dos 
animais e a manutenção dos equipamentos e benfeitorias. Nessa atividade, o planejamento estratégico da produção é realizado pela indústria, que também fornece praticamente todos os insumos necessários à produção dos lotes de frango, além dos serviços de assistência técnica e de transporte dos frangos ao abatedouro. Após o término da recria, engorda e abate dos lotes de frangos, cujo ciclo de produção tem duração média de 45 dias, é feito o acerto financeiro entre a indústria e o produtor. Nessa ocasião, o produtor recebe a diferença entre o valor da produção entregue menos o valor dos insumos e serviços fornecidos pela indústria. Apesar do alto grau tecnológico utilizado na produção dos frangos, a lucratividade dessa atividade normalmente é baixa, mas o risco de prejuízos também é pequeno, dada a política de remuneração da atividade adotada pela indústria integradora. Para a propriedade, a grande vantagem da avicultura, são as freqüentes receitas líquidas auferidas com a atividade, que contribuem significativamente para o custeio dos gastos familiares e para o pagamento de alguns empregados permanentes da propriedade.

$\mathrm{Na}$ empresa referencial Frango, toda a mão-de-obra familiar reside e trabalha em tempo integral na propriedade, inclusive a mulher e as filhas maiores. $\mathrm{Na}$ execução dos serviços manuais, há uma certa divisão de responsabilidades entre os membros da família, com a mulher e as filhas maiores dedicando a maior parte de seu tempo de trabalho às atividades pecuárias (aves e leite). Nessa empresa, a mão-de-obra familiar responde por aproximadamente metade do tempo total de trabalho, sendo o restante do trabalho cumprido, principalmente, por empregados permanentes. A mão-deobra temporária é contratada esporadicamente ao longo do ano, principalmente, para auxiliar nos serviços de colheita do feijão ou em outras situações extraordinárias, onde há picos de necessidade adicional de mão-de-obra. Dos membros da família, o pai e os filhos maiores, normalmente, são os que comandam a propriedade. Nessa empresa, os tomadores de decisão geralmente possuem um baixo a médio espírito empreendedor, e uma média a alta aversão ao risco. 
As quintas colunas dos Quadros 2 a 5 sintetizam algumas informações sobre a empresa referencial Frango. A discussão sobre os problemas levantados nesta seção e a recomendação de formas alternativas de gestão, para a empresa referencial Frango, será feita adiante nos itens 6.2 a 6.6.

\subsubsection{Empresa referencial "Hortifruti" (HF).}

$\mathrm{Na}$ empresa referencial denominada Hortifruti a renda total da propriedade advém da exploração da horticultura e da fruticultura. São vários os produtos produzidos em cada uma dessas explorações e, portanto, vários são os ciclos (tempo) de produção das atividades encontradas nessa empresa, principalmente na horticultura. Dos 20 hectares que compõem a área total da propriedade, cerca de 15 hectares são permanentemente cultivados, sendo 10 hectares com fruticultura e 5 com horticultura. Da renda bruta anual, cerca de $50 \%$ provém da comercialização das frutas e $50 \%$ da comercialização das verduras e legumes.

A totalidade da produção é destinada ao mercado regional, mas vários são os canais de comercialização adotados pela empresa, dentre os quais destacam-se: (a) a venda de parte da produção a atacadistas, que atuam na região da propriedade e nas Centrais Regionais de Abastecimento (CEASAS); (b) a venda de parte da produção a varejistas estabelecidos na região da propriedade; (c) a venda de parte da produção diretamente ao consumidor, através das feiras-livres realizadas em cidades próximas a propriedade; e (d) a venda de parte da produção através de cestas, com vários produtos da empresa, diretamente a consumidores finais. Pela ordem, de (a) a (d), esses diferentes canais de comercialização apresentam preços crescentes para o produtor rural. As vendas realizadas diretamente aos consumidores finais são feitas sob marca própria. Nessa modalidade de venda a empresa obtém os maiores preços de comercialização, mas essa alternativa de venda não consegue absorver o volume total dos produtos produzidos ao longo do ano. 
$\mathrm{Na}$ empresa referencial Hortifruti a maior parte da mão-de-obra familiar trabalha na propriedade, mas ela tem pequena participação no trabalho total, tendo em vista a alta demanda por mão-de-obra nesse tipo de empresa. Nos serviços de produção e comercialização a família conta com o trabalho de funcionários contratados, em sua maioria por tempo indeterminado. Nos momentos de plantio e colheita ou em outras situações extraordinárias de maior demanda por mão-de-obra, a empresa contrata trabalhadores temporários.

A empresa referencial Hortifruti conta com veículos próprios para a distribuição da produção, sobretudo para o transporte dos produtos destinados às feiraslivres, aos varejistas e aos consumidores finais. A distribuição da produção é diária, tendo em vista os contratos de entrega mantidos pela empresa. Eventualmente, a empresa referencial Hortifruti adquire produtos de outros produtores, a fim de cumprir com os compromissos de entrega da produção, assumidos com seus clientes.

As penúltimas colunas dos Quadros 2 a 5 sintetizam algumas informações sobre a empresa referencial Hortifruti. A discussão sobre os problemas levantados nesta seção e a recomendação de formas alternativas de gestão, para a empresa referencial Hortifruti, será feita adiante nos itens 6.2 a 6.6.

\subsubsection{Empresa referencial "Pequena Produção" (PP).}

A empresa referencial denominada Pequena Produção possui uma área de terras de aproximadamente 10 hectares, dos quais 6 hectares são ocupados por lavouras, 3 hectares por pecuária e 1 hectare compõe as áreas de moradia, reserva legal, inaproveitáveis e destinadas a outros usos. A área de lavoura é cultivada duas vezes ao ano, perfazendo uma área anual explorada com agricultura de 12 hectares. No verão, a terra é normalmente ocupada por lavouras como o milho (3 ha), o algodão (1 ha) e o 
feijão (2 ha). No inverno, a terra é normalmente ocupada pelas seguintes lavouras: milho safrinha (2 ha); feijão de inverno ou de segunda safra (2 ha); e aveia (2 ha).

A área destinada à pecuária ocupa os terrenos de maior declividade na propriedade. Nesse local, encontram-se as pastagens perenes destinadas à alimentação do gado, e pequenas áreas com forrageiras, destinadas à suplementação alimentar do rebanho na estação seca. Também na estação seca, parte da produção de milho e de aveia é destinada à alimentação do gado. $\mathrm{O}$ rebanho existente na propriedade é predominantemente leiteiro e composto, em sua maioria, por gado mestiço, de dupla aptidão (carne e leite).

$\mathrm{Na}$ empresa referencial Pequena Produção, os seguintes produtos se destacam na formação da renda bruta anual: milho (30\%), feijão (30\%), leite (25\%), algodão (10\%) e aveia (5\%). Da produção total, a maior parte é vendida a comerciantes da região, e o restante consumido na própria propriedade. No caso dos produtos agrícolas, a principal estratégia de comercialização é a venda da produção logo após a colheita. Nessas ocasiões, as receitas auferidas são normalmente destinadas ao custeio familiar, ao pagamento de dívidas (adiantamentos) junto ao comércio varejista e fornecedores de insumos agrícolas, e a pequenos investimentos na propriedade.

Dentre os objetivos do produtor rural, na empresa referencial Pequena Produção, destacam-se a manutenção do bem estar familiar e a ocupação da mão-deobra familiar na propriedade. Desta forma, as estratégias de produção normalmente adotadas privilegiam a redução do risco e a estabilidade da renda. Nessa empresa, toda a mão-de-obra familiar reside e trabalha em tempo integral na propriedade, inclusive a mulher e as filhas maiores. Do tempo total de trabalho na propriedade, a mão-de-obra familiar responde por mais de dois terços do total. A mão-de-obra fixa contratada responde por aproximadamente $20 \%$ e a mão-de-obra temporária pelos cerca de $10 \%$ restantes. Geralmente, a contratação temporária de mão-de-obra é feita para realização das colheitas de feijão e algodão e correspondem à troca de serviços, ou seja, a permutas 
de trabalho com produtores vizinhos. Também é comum a compra de alguns serviços mecanizados de terceiros, por exemplo, para o preparo do solo, plantio, aplicação de defensivos, colheita (de milho) e transporte da produção agrícola.

Nos serviços operacionais de produção, as tarefas dos funcionários e dos membros da família são distribuídas no dia-a-dia pelo produtor rural, conforme a necessidade de trabalho em cada atividade. Todos os membros da família realizam serviços operacionais e opinam sobre as decisões estratégicas. Eventualmente, a empresa recebe serviços públicos de assistência técnica, mas a troca de experiências com os produtores vizinhos se constitui em uma importante fonte de informação para o produtor rural.

As últimas colunas dos Quadros 2 a 5 sintetizam algumas informações sobre a empresa referencial Pequena Produção. A discussão sobre os problemas levantados nesta seção e a recomendação de formas alternativas de gestão, para a empresa referencial Pequena Produção, será feita adiante nos itens 6.2 a 6.6.

\subsection{A importância da gestão por áreas administrativas}

O conhecimento das áreas administrativas de produção, finanças, comercialização e pessoal das empresas agropecuárias facilita o estabelecimento de estratégias para a prática da administração rural nessas empresas, seja pelos próprios produtores rurais, seja pelos profissionais da assistência técnica. Nesta secção, é apresentada a relevância de diferentes atividades administrativas nas empresas agropecuárias referenciais descritas na secção anterior. Estabelecidos os graus de relevância para a gestão ${ }^{48}$ estratégica e operacional das diferentes áreas administrativas, uma análise mais detalhada será apresentada em seguida. Ela procurará estabelecer, à luz

\footnotetext{
$\overline{48}$ Aqui o termo "gestão" se refere ao conjunto de todas as funções administrativas: planejamento, organização, direção e controle.
} 
do modelo teórico proposto e dos resultados obtidos nesse trabalho, prováveis graus de relevância para cada função administrativa nas diferentes empresas agropecuárias referencias e, portanto, as correspondentes formas mais prováveis para a implantação de melhorias no processo administrativo dessas empresas.

Cabe ressaltar que os resultados qualitativos e quantitativos (apresentados no capítulo 5) poderiam, em parte, serem extrapolados para as empresas referenciais "Grãos" e "Bovino de Corte". Mesmo assim, a generalização de recomendações administrativas não tem significância estatística, pois as empresas referenciais foram idealizadas e não houve teste estatístico para comprovar se elas se assemelham ao universo das empresas pesquisadas. Além disso, no caso das demais empresas referenciais as proposições aqui apresentadas são meras suposições que visam demonstrar aos profissionais da assistência técnica formas alternativas para a observação e análise de empresas agropecuárias.

O Quadro 6 contém estimativas sobre o grau de relevância (ou importância) da gestão estratégica e operacional das diversas áreas administrativas, para as 7 empresas agropecuárias referencias descritas na secção anterior. No Quadro 6, a menor ou maior relevância das diferentes atividades administrativas é indicada em uma escala ordinal, de acordo com o número (em uma escala de 1 a 5) presente em cada elemento da matriz de 8 linhas e 7 colunas. Nos elementos da matriz (8x7), o número indicado representa a estimativa para o grau de relevância da gestão das diferentes áreas administrativas em cada empresa agropecuária referencial, sendo que: o número 5 indica um grau muito alto de importância; o número 4 indica um grau alto de importância; o número 3 um médio grau de importância; o número 2 um grau regular de importância e, o número 1 indica um baixo grau de importância. 
Quadro 6. Estimativas sobre o grau de importância (ou relevância) da gestão estratégica e operacional por área administrativa, segundo as diferentes empresas agropecuárias referenciais.

\begin{tabular}{|l|c|c|c|c|c|c|c|}
\hline & \multicolumn{7}{|c|}{ Empresas agropecuárias referenciais } \\
\hline & Grãos & $\begin{array}{c}\text { Bovino } \\
\text { de Corte }\end{array}$ & $\begin{array}{c}\text { Cana-de- } \\
\text { açúcar }\end{array}$ & Café & Frango & Hortifruti & $\begin{array}{c}\text { Pequena } \\
\text { Produção }\end{array}$ \\
\hline GE $^{1}$ Produção & 4 & 4 & 3 & 4 & 3 & 4 & 4 \\
\hline GO $^{2}$ Produção & 5 & 3 & 3 & 4 & 4 & 5 & 5 \\
\hline GE Finanças & 3 & 3 & 2 & 3 & 2 & 4 & 3 \\
\hline GO Finanças & 5 & 3 & 2 & 3 & 2 & 5 & 2 \\
\hline GE Comercialização & 3 & 4 & 1 & 3 & 1 & 5 & 2 \\
\hline GO Comercialização & 4 & 4 & 1 & 4 & 1 & 5 & 3 \\
\hline GE Pessoal & 3 & 2 & 1 & 3 & 3 & 3 & 3 \\
\hline GO Pessoal & 4 & 2 & 1 & 4 & 4 & 4 & 4 \\
\hline
\end{tabular}

${ }^{1} \mathrm{GE}$ (gestão estratégica)

${ }^{2}$ GO (gestão operacional)

Pelo exposto no Quadro 6, pode-se observar diferenças de relevância na gestão das áreas administrativas nas empresas referenciais. Na segunda linha do Quadro 6, por exemplo, pode-se observar que a gestão operacional da produção possui uma maior relevância nas empresas "Grãos", "Hortifruti" e "Pequena Produção" (com grau 5), relativamente as empresas "Bovino de Corte" e "Cana-de-açúcar" (com grau 3). Da mesma forma, através do Quadro 6 pode-se observar, pelos dados da segunda coluna, que a gestão da comercialização na empresa "Bovino de Corte" (grau 4) possui maior relevância do que a gestão do pessoal nessa empresa (grau 2). Assim, pode-se esperar que o esforço, de produtores e técnicos, na melhoria do processo administrativo de empresas agropecuárias privilegie a gestão de áreas administrativas mais importantes para cada caso. 
A determinação do grau de importância, para a gestão estratégica e operacional nas empresas agropecuárias, depende de um bom conhecimento sobre o funcionamento interno dessas empresas e sobre o ambiente onde estão inseridas. Assim, uma análise das principais variáveis do ambiente externo e interno da empresa agropecuária, permite ao profissional deduzir sobre a maior ou menor relevância da gestão em cada área administrativa da empresa. A seguir, descreve-se alguns dos fatores considerados no estabelecimento dessas estimativas, comparando-se os maiores e menores valores indicados em cada uma das linhas do Quadro 6.

1) Gestão estratégica da produção (linha 1 do Quadro 6):

a) Tem apenas importância média (grau 3) nas empresas "Cana-de-açúcar" e "Frango", pelo fato da estratégia da produção ser estabelecida observando-se as orientações da indústria.

b) Tem alta importância (grau 4) nas demais empresas referencias citadas, pela necessidade da estratégia de produção ser definida pelo empresário nessas empresas.

2) Gestão operacional da produção (linha 2 do Quadro 6):

a) Tem importância muito alta (grau 5) nas empresas referenciais "Grãos", "Hortifruti" e "Pequena Produção". Isto se explica por uma conjunção de fatores, que exigem atenção permanente do produtor, tais como: alta freqüência de suas atividades operacionais; maior complexidade de seu processo produtivo; entre outros.

b) Tem importância média (grau 3) na empresa "Bovino de Corte" pela menor complexidade de seu processo produtivo e, na empresa "Cana-de-açúcar", pelo fato da indústria ser responsável pela maioria de suas atividades operacionais.

3) Gestão estratégica das finanças (linha 3 do Quadro 6):

a) Tem alta importância (grau 4) na empresa referencial "Hortifruti", pelo curto ciclo de produção de suas explorações e pela maior dinâmica do mercado onde está inserida.

b) Tem importância regular (grau 2) nas empresas referenciais "Cana-de-açúcar" e "Frango", pelo fato da indústria bancar (ou financiar) a maior parte do capital de giro necessário a produção.

4) Gestão operacional das finanças (linha 4 do Quadro 6): 
a) Tem importância muito alta (grau 5) nas empresas "Grãos" e "Hortifruti", em função do elevado montante e da alta freqüência dos valores transacionados em compras e vendas, e pela dinâmica dos mercados onde estão inseridas.

b) Tem importância regular (grau 2) nas empresas referenciais "Cana-de-açúcar" e "Frango", pelo baixo volume de transações financeiras realizadas com o mercado livre.

5) Gestão estratégica da comercialização (linha 5 do Quadro 6):

a) Tem importância muito alta (grau 5) na empresa referencial "Hortifruti" pela dinâmica do mercado onde atua, pelo grande número de produtos produzidos e pela utilização de diversos canais de comercialização para vender sua produção.

b) Tem importância alta (grau 4) na empresa referencial "Bovino de Corte", pela dinâmica produtiva e comercial de suas atividades (categorias que compõem o rebanho) e pelas dificuldades estruturais do mercado onde atua.

c) Tem baixa importância (grau 1) nas empresas referenciais "Cana-de-açúcar" e "Frango", pelo fato da produção ser comercializada com um único cliente pelo sistema de integração que participam.

6) Gestão operacional da comercialização (linha 6 do Quadro 6):

a) Tem importância muito alta (grau 5) na empresa referencial "Hortifruti" pela alta freqüência de suas vendas, pelo grande número de clientes que possui e pela maior perecibilidade de seus produtos.

b) Tem importância alta (grau 4) na empresa referencial "Bovino de Corte" pela falta de padronização de produtos nesse mercado, e na empresa referencial "Grãos" pela grande diversidade de fornecedores alternativos com os quais trabalha, e pela variabilidade de preços no mercado de produtos.

c) Tem baixa importância (grau 1) nas empresas referenciais "Cana-de-açúcar" e "Frango", pelo fato produção ser comercializada por preços médios estabelecidos pelo sistema de integração.

7) Gestão estratégica do pessoal (linha 7 do Quadro 6):

a) Tem baixa importância (grau 1) na empresa referencial "Cana-de-açúcar", em função da grande parte dos serviços manuais serem realizados pela empresa integradora. 
b) Tem importância regular (grau 2) na empresa referencial "Bovino de Corte" pela baixa demanda de mão-de-obra nesse tipo de atividade.

c) Têm média importância (grau 3) na empresa referencial "Grãos" pela dificuldade de logística de suas atividades exigindo mão-de-obra qualificada e, nas demais empresas referenciais pela importância da mão-de-obra nos custos de produção.

8) Gestão operacional do pessoal (linha 8 do Quadro 6):

a) Tem baixa importância (grau 1) na empresa referencial "Cana-de-açúcar" em função da baixa disponibilidade de mão-de-obra fixa nessa empresa.

b) Tem importância regular (grau 2) na empresa referencial "Bovino de Corte" pela simplicidade das tarefas manuais realizadas.

c) Têm importância alta (grau 4) nas demais empresas referenciais pelo uso cotidiano da mão-de-obra nessas empresas em tarefas fundamentais para o processo produtivo.

É possível também, a partir do Quadro 6, discutir a relevância da gestão das áreas administrativas por empresa referencial (colunas do Quadro 6). Os itens, a seguir, enumeram os principais fatores considerados nas estimativas de relevância da gestão em cada área administrativa das empresas referenciais.

1) Empresa referencial “Grãos” (coluna 1 do Quadro 6):

a) Tem importância muito alta (grau 5) a gestão operacional da produção e das finanças, pela complexidade do processo produtivo e pela alta freqüência e magnitude de suas transações comerciais (notadamente na compra de insumos).

b) Tem média importância (grau 3) a gestão estratégica das finanças, da comercialização e do pessoal. No caso das finanças, pela incerteza em se prever o volume e a qualidade da produção. No caso da comercialização, pelo fato da empresa produzir "commodities” e no caso do pessoal, por uma certa facilidade em se substituir a mão-de-obra empregada.

2) Empresa referencial "Bovino de Corte" (coluna 2 do Quadro 6):

a) Têm alta importância (grau 4) a gestão estratégica da produção e a gestão estratégica e operacional da comercialização. No caso da produção, pelo longo tempo necessário 
para se atingir as metas estabelecidas. No caso da comercialização, pela dinâmica do rebanho (estratégia) e pela natureza complexa do mercado onde atua (operacional).

b) Tem baixa importância (grau 2) a gestão estratégica e operacional do pessoal, pela baixa demanda por mão-de-obra nessa empresa.

3) Empresa referencial "Cana-de-açúcar" (coluna 3 do Quadro 6):

a) Tem importância média (grau 3) a gestão estratégica e operacional da produção, pelo fato da indústria auxiliar no processo produtivo mas não se responsabilizar pelas variações de produtividade.

b) Tem baixa importância (grau 1) a gestão da comercialização e do pessoal. No caso da comercialização, por receber preços médios definidos pelo mercado. No caso do pessoal, pelo fato da indústria se responsabilizar pela maioria dos serviços manuais.

4) Empresa referencial "Café" (coluna 4 do Quadro 6):

a) Tem alta importância (grau 4) a gestão estratégica e operacional da produção e a gestão operacional da comercialização e pessoal. No caso da produção, pela complexidade do processo produtivo, e pela preferência desse mercado por produtos de qualidade. No caso da comercialização, pelos diversos tipos de produtos comercializados nesse mercado. No caso do pessoal, pela grande quantidade de trabalhadores envolvidos no processo produtivo.

b) Tem importância média (grau 3) a gestão das finanças e a gestão estratégica da comercialização e do pessoal. No caso das finanças, pelo maior tempo de produção dessa atividade. No caso da comercialização, pela baixa possibilidade da empresa de conquistar mercados alternativos. No caso do pessoal, pela segurança em dispor de boa oferta familiar de mão-de-obra.

5) Empresa referencial "Frango" (coluna 5 do Quadro 6):

a) Tem alta importância (grau 4) a gestão operacional da produção e do pessoal. No caso da produção, pela pouca flexibilidade tecnológica de seu processo produtivo. No caso do pessoal, pela pouca flexibilidade da rotina diária dos serviços manuais.

b) Tem baixa importância (grau 1) a gestão da comercialização, pelo fato da indústria fornecer a maioria dos insumos e adquirir a totalidade da produção.

6) Empresa referencial "Hortifruti” (coluna 6 do Quadro 6): 
a) Tem importância muito alta (grau 5) a gestão operacional da produção e das finanças e a gestão estratégica e operacional da comercialização. No caso da produção, pela diversidade dos produtos produzidos. No caso das finanças, pela complexidade de seu fluxo de caixa. No caso da comercialização, pela diversidade de clientes e fornecedores e pela perecibilidade de sua produção.

b) Tem média importância (grau 3) a gestão estratégica do pessoal, pela certa facilidade em se substituir a mão-de-obra existente na empresa.

O Quadro 7 apresenta estimativas sobre o grau de relevância das diferentes atividades administrativas para o sucesso das empresas agropecuárias referenciais. Em sua estrutura, o Quadro 7 segue o mesmo princípio de construção do Quadro 6, mas detalha a relevância para cada uma das diferentes funções (planejamento, organização, direção e controle) que compõem o processo administrativo das empresas, resultando em uma matriz de 32 linhas e 7 colunas. No Quadro 7, a menor ou maior relevância das atividades administrativas também é indicada pela escala ordinal (de 1 a 5) presente em cada elemento da matriz (32x7), sendo que: o número 5 indica um grau muito alto de importância; o número 4 um grau alto de importância; o número 3 um médio grau de importância; o número 2 um grau regular e, o número 1 um baixo grau de importância.

Pelo exposto no Quadro 7, pode-se observar diferenças de relevância nas funções que compõem o processo de gestão das áreas administrativas nas empresas referenciais. Na primeira coluna do Quadro 7, por exemplo, pode-se observar que o planejamento estratégico da produção na empresa "Grãos" (grau 5) possui maior relevância do que o controle estratégico da produção (grau 3) na mesma empresa. Da mesma forma, na coluna 5 do Quadro 7, pode-se observar que o planejamento operacional da produção na empresa "Frango" (grau 4) possui menor relevância do que a direção operacional da produção (grau 5) na mesma empresa. 
Quadro 7 - Estimativas sobre o grau de importância (ou relevância) das diferentes atividades administrativas para o sucesso das empresas agropecuárias referenciais (escala de 0 a 5$)^{1}$.

\begin{tabular}{|c|c|c|c|c|c|c|c|}
\hline Atividades administrativas & $\begin{array}{c}\text { EMPRESA } \\
\text { GRÃOS }\end{array}$ & $\begin{array}{c}\text { EMPRESA } \\
\text { BOVINO } \\
\text { DE CORTE }\end{array}$ & $\begin{array}{l}\text { EMPRESA } \\
\text { CANA-DE- } \\
\text { AÇÚCAR }\end{array}$ & $\begin{array}{c}\text { EMPRESA } \\
\text { CAFÉ }\end{array}$ & $\begin{array}{c}\text { EMPRESA } \\
\text { FRANGO }\end{array}$ & $\begin{array}{c}\text { EMPRESA } \\
\text { HORTIFRUTI }\end{array}$ & $\begin{array}{c}\text { EMPRESA } \\
\text { PEQUENA } \\
\text { PRODUÇÃO }\end{array}$ \\
\hline Planejamento estratégico da produção & 5 & 4 & 3 & 4 & 3 & 5 & 5 \\
\hline Organização estratégica da produção & 4 & 4 & 2 & 3 & 2 & 4 & 4 \\
\hline Direção estratégica da produção & 4 & 4 & 3 & 4 & 3 & 4 & 4 \\
\hline Controle estratégico da produção & 3 & 3 & 2 & 3 & 2 & 3 & 3 \\
\hline Planejamento operacional da produção & 5 & 4 & 3 & 5 & 4 & 5 & 5 \\
\hline Organização operacional da produção & 5 & 3 & 2 & 4 & 2 & 5 & 5 \\
\hline Direção operacional da produção & 5 & 3 & 3 & 5 & 5 & 5 & 5 \\
\hline Controle operacional da produção & 3 & 2 & 2 & 3 & 3 & 4 & 3 \\
\hline Planejamento estratégico das finanças & 4 & 4 & 2 & 3 & 2 & 4 & 4 \\
\hline Organização estratégica das finanças & 3 & 3 & 2 & 3 & 2 & 4 & 3 \\
\hline Direção estratégica das finanças & 4 & 3 & 2 & 3 & 2 & 4 & 3 \\
\hline Controle estratégico das finanças & 3 & 3 & 2 & 3 & 2 & 4 & 3 \\
\hline Planejamento operacional das finanças & 5 & 3 & 2 & 3 & 2 & 5 & 3 \\
\hline Organização operacional das finanças & 4 & 3 & 2 & 3 & 2 & 5 & 2 \\
\hline Direção operacional das finanças & 5 & 2 & 2 & 3 & 2 & 5 & 2 \\
\hline Controle operacional das finanças & 4 & 2 & 2 & 3 & 2 & 5 & 2 \\
\hline
\end{tabular}


Quadro 7 - Estimativas sobre o grau de importância (ou relevância) das diferentes atividades administrativas para o sucesso das empresas agropecuárias referenciais (escala de 1 a 5$)^{1}$.

\begin{tabular}{|c|c|c|c|c|c|c|c|}
\hline Atividades administrativas & $\begin{array}{c}\text { EMPRESA } \\
\text { GRÃOS }\end{array}$ & $\begin{array}{c}\text { EMPRESA } \\
\text { BOVINO } \\
\text { DE CORTE }\end{array}$ & $\begin{array}{l}\text { EMPRESA } \\
\text { CANA-DE- } \\
\text { AÇÚCAR } \\
\end{array}$ & $\begin{array}{l}\text { EMPRESA } \\
\text { CAFÉ }\end{array}$ & $\begin{array}{l}\text { EMPRESA } \\
\text { FRANGO }\end{array}$ & $\begin{array}{c}\text { EMPRESA } \\
\text { HORTIFRUTI }\end{array}$ & $\begin{array}{c}\text { EMPRESA } \\
\text { PEQUENA } \\
\text { PRODUÇÃO }\end{array}$ \\
\hline Planejamento estratégico da comercialização & 4 & 4 & 1 & 3 & 1 & 5 & 2 \\
\hline Organização estratégica da comercialização & 3 & 4 & 1 & 3 & 1 & 5 & 2 \\
\hline Direção estratégica da comercialização & 3 & 4 & 1 & 3 & 1 & 5 & 2 \\
\hline Controle estratégico da comercialização & 2 & 4 & 1 & 3 & 1 & 4 & 2 \\
\hline Planejamento operacional da comercialização & 4 & 4 & 1 & 4 & 1 & 5 & 3 \\
\hline Organização operacional da comercialização & 3 & 4 & 1 & 3 & 1 & 5 & 3 \\
\hline Direção operacional da comercialização & 5 & 5 & 1 & 4 & 1 & 5 & 3 \\
\hline Controle operacional da comercialização & 3 & 4 & 2 & 4 & 2 & 4 & 3 \\
\hline Planejamento estratégico do pessoal & 3 & 2 & 2 & 4 & 3 & 4 & 4 \\
\hline Organização estratégica do pessoal & 3 & 2 & 1 & 3 & 3 & 3 & 3 \\
\hline Direção estratégica do pessoal & 3 & 2 & 1 & 3 & 3 & 3 & 3 \\
\hline Controle estratégico do pessoal & 3 & 2 & 1 & 3 & 3 & 3 & 3 \\
\hline Planejamento operacional do pessoal & 4 & 2 & 1 & 5 & 4 & 5 & 5 \\
\hline Organização operacional do pessoal & 3 & 2 & 1 & 4 & 4 & 4 & 4 \\
\hline Direção operacional do pessoal & 4 & 2 & 1 & 5 & 5 & 5 & 5 \\
\hline Controle operacional do pessoal & 3 & 2 & 2 & 3 & 3 & 3 & 3 \\
\hline
\end{tabular}

${ }^{1}$ Os números no interior do Quadro indicam o grau de importância das atividades administrativas, sendo que o número 5 representa um grau muito alto de importância e o número 1 um grau baixo de importância. 
Nas secções 6.3 a 6.6, a seguir, discute-se em separado a relevância de cada uma das funções do processo administrativo.

\subsection{O planejamento nas empresas agropecuárias referenciais}

\subsubsection{Relevância do planejamento}

De alguma ou de outra forma, a grande maioria dos empresários fazem planejamento. O simples ato de pensar para decidir já pode ser considerado um ato de planejamento. $\mathrm{O}$ ato de pensar envolve indagações, e indagações envolvem questionamentos sobre o que fazer, como, quando, quanto, para quem, por que e onde. Assim, o planejamento poderia ser entendido como um esforço contínuo (mental ou por escrito) que busca saber quais são as implicações futuras das decisões presentes.

O Quadro 08, que reproduz parte do Quadro 1 no intuito de facilitar sua visualização, apresenta exemplos de atividades administrativas relacionadas ao planejamento estratégico e operacional da produção. Normalmente, questionamentos do tipo "o que fazer" relacionam-se a decisões estratégicas e questionamentos do tipo "como fazer" a decisões de ordem operacional. Assim, o esforço (mental ou por escrito) do tomador de decisão, realizado para identificar e definir a(s) atividade(s) a ser(em)

realizada(s) na empresa e suas correspondentes implicações futuras, trata de uma atividade administrativa relacionada à função administrativa "planejamento estratégico da produção". Da mesma forma, o esforço (mental ou por escrito) do tomador de decisão, realizado para identificar, definir e avaliar o(s) sistema(s) de produção (tecnologia) a ser(em) adotado(s) na empresa, trata-se de uma atividade administrativa relacionada à função administrativa "planejamento operacional da produção". 
Quadro 08 - Exemplos de atividades administrativas em empresas agropecuárias relacionadas ao planejamento estratégico e operacional da produção.

\begin{tabular}{|c|c|}
\hline $\begin{array}{c}\text { Função } \\
\text { administrativa }\end{array}$ & Exemplos de atividades administrativas \\
\hline $\begin{array}{c}\text { Planejamento } \\
\text { estratégico da } \\
\text { produção }\end{array}$ & $\begin{array}{l}\Rightarrow \text { Identificar e definir as atividades (culturas e criações) a serem } \\
\text { realizadas pela empresa, considerando fatores como: as } \\
\text { disponibilidades e as exigências de recursos; os riscos e as } \\
\text { rentabilidades potenciais; as ameaças e as oportunidades do } \\
\text { ambiente; e os gostos e as preferências do produtor rural e sua } \\
\text { família. } \\
\Rightarrow \text { Projetar o desempenho produtivo da empresa e a alocação dos } \\
\text { recursos necessários a produção. }\end{array}$ \\
\hline $\begin{array}{c}\text { Planejamento } \\
\text { operacional da } \\
\text { produção }\end{array}$ & $\begin{array}{l}\Rightarrow \text { Definir o sistema de produção (tecnologia) e estabelecer } \\
\text { metas de produção e produtividade. } \\
\Rightarrow \text { Estabelecer cronograma físico das tarefas e operações para } \\
\text { cada uma das atividades da empresa. }\end{array}$ \\
\hline
\end{tabular}

Nas empresas agropecuárias brasileiras, muito poucos empresários fazem planejamento por escrito. Nessas empresas, o planejamento geralmente é realizado de forma mental ou intuitiva. Mesmo assim, o exercício sistemático do planejamento (de forma mental ou intuitiva) nas empresas agropecuárias pode, em alguns casos, dependendo da habilidade e experiência do empresário, contribuir efetivamente para reduzir a incerteza envolvida no processo decisório e, conseqüentemente, aumentar a probabilidade de alcance dos objetivos e desafios estabelecidos. Cabe ressaltar também, que a maior ou menor complexidade produtiva e/ou comercial das atividades conduzidas pela empresa tornam mais ou menos necessário o esforço de planejamento nas diferentes empresas. A repetição ou periodicidade desse esforço de planejamento é, por sua vez, influenciada pelo tempo ou ciclo de produção das atividades agropecuárias. Há que se 
diferenciar também, o esforço de planejamento estratégico e de planejamento operacional.

No caso das empresas agropecuárias referenciais, descritas no item 6.1, pode-se esperar, por exemplo, que a freqüência de realização de planejamentos operacionais da produção, em função da esperada freqüência de tomadas de decisões operacionais nessas empresas, tenha a seguinte ordenação decrescente: com a maior freqüência, ter-se-ia a empresa referencial "Hortifruti", seguida, respectivamente, pelas empresas "Frango", "Grãos", "Pequena Produção", "Bovino de Corte”, "Café” e "Canade-açúcar”. Já, para a freqüência de planejamento estratégico da produção poder-se-ia esperar a seguinte ordenação decrescente: "Hortifruti”, "Grãos”, "Pequena Produção", "Bovino de Corte", "Frango", "Cana-de-açúcar" e "Café”. Por outro lado, se considerada a complexidade do processo produtivo e a correspondente necessidade de alterações ou ajustes operacionais no sistema de produção, se poderia esperar a seguinte ordenação decrescente para a freqüência do esforço de planejamento operacional: com a maior frequiência, ter-se-ia a empresa referencial "Hortifruti", seguida, respectivamente, pelas empresas, "Grãos”, "Pequena Produção", "Café”, "Bovino de Corte", "Frango" e "Cana-de-açúcar". Diante do exposto nesses exemplos, pode-se constatar a dificuldade em se atribuir um exato grau de importância (ou relevância) para as diferentes atividades administrativas das empresas agropecuárias. Apesar disto, quando se observam algumas das principais características das empresas agropecuárias nos aspectos produtivo, comercial, financeiro e humano, pode-se, com certo grau de precisão, se atribuir um determinado grau de importância relativa para as diferentes atividades administrativas nas empresas agropecuárias.

O Quadro 09, que reproduz parte do Quadro 7 no intuito de facilitar sua visualização, apresenta estimativas sobre o grau de importância do planejamento estratégico e operacional da produção para o sucesso das empresas agropecuárias referenciais. No caso do planejamento estratégico da produção, o grau de importância é maior nas empresas referenciais "Grãos", "Hortifruti" e "Pequena Produção" e menor 
nas empresas referenciais "Cana-de-açúcar" e "Frango". No caso do planejamento operacional da produção, o grau de importância é maior nas empresas referenciais "Grãos", "Café", "Hortifruti" e "Pequena Produção" e menor na empresa referencial "Cana-de-açúcar".

Quadro 09 - Estimativas sobre o grau de importância (ou relevância) do planejamento estratégico e operacional da produção para o sucesso das empresas agropecuárias referenciais (escala de 1 a 5).

\begin{tabular}{|l|c|c|}
\hline Empresas Referenciais & $\begin{array}{c}\text { Planejamento estratégico da } \\
\text { produção }\end{array}$ & $\begin{array}{c}\text { Planejamento operacional da } \\
\text { produção }\end{array}$ \\
\hline Grãos & 5 & 5 \\
\hline Bovino de Corte & 4 & 4 \\
\hline Cana-de-açúcar & 3 & 5 \\
\hline Café & 4 & 4 \\
\hline Frango & 3 & 5 \\
\hline Hortifruti & 5 & 5 \\
\hline Pequena Produção & 5 & \\
\hline
\end{tabular}

De uma forma geral, é alto o grau de importância do planejamento estratégico e operacional da produção nas empresas agropecuárias referenciais, conforme mostra o número mínimo 3 no Quadro 9. Isso ocorre por que a eficiência na área da produção é vital para as empresas agropecuárias, pois a produção primária representa a razão principal de sua existência e é a produção primária a base para a formação de sua renda bruta. $\mathrm{Na}$ área da produção, os erros em decisões estratégicas têm um alto custo para serem sanados ou corrigidos, pois, normalmente, é longo e irreversível o processo produtivo agropecuário, e altos são os investimentos necessários para se iniciar ou modificar a infraestrutura de apoio à produção. Em nível operacional, decisões erradas na área da produção normalmente reduzem a produtividade das 
explorações e, por conseguinte, as margens líquidas possíveis de serem obtidas em um determinado ciclo de produção. Além das incertezas com relação à produção futura das alternativas em análise na empresa agropecuária, também as incertezas com relação aos preços de mercado dos produtos, à disponibilidade de crédito para as diferentes atividades, entre outras, contribuem para uma grande importância de um eficiente planejamento da produção. É possível, entretanto, que essas incertezas comuns ao meio agropecuário contribuam para uma inércia da ação empresarial, resultando em lentas modificações nos sistemas de produção das empresas agropecuárias. Neste sentido, não se pode confundir rigidez na produção agropecuária (oferta inelástica em relação a preços) com ausência de planejamento nas empresas agropecuárias. Muitas vezes, no curto prazo, o alto custo para se alterar a infraestrutura da propriedade torna a manutenção do atual sistema de produção a melhor opção apontada pelo processo de planejamento.

De uma forma geral, contribuem para o baixo uso do planejamento escrito nas empresas agropecuárias do país, os seguintes fatores: (a) pouco conhecimento, por parte dos produtores rurais, sobre as modalidades formais de elaboração do planejamento estratégico e operacional, principalmente devido à falta de tradição e prática dessas técnicas no meio rural; (b) desestímulo dos empresários em escriturar seus planos e metas, principalmente em função das constantes mudanças em variáveis do ambiente (clima, política agrícola, preços, disponibilidades de tecnologia, etc.) que não são controláveis por eles, e a conseqüente necessidade de se readequar ou reorientar periodicamente os planos operacionais na empresa agropecuária; (c) desobrigação formal dos produtores rurais de prestar contas a terceiros sobre suas decisões estratégicas e operacionais, principalmente devido à existência predominante de firmas de propriedade ou gerência individual no meio rural. Assim, a desobrigação de prestar contas a terceiros pode explicar, por exemplo, um maior uso do planejamento escrito na empresa referencial "Grãos", relativamente à empresa referencial "Bovino de Corte", pelo fato da primeira, hipoteticamente, contratar maior volume de crédito junto a terceiros. Ou alternativamente, as constantes mudanças no ambiente podem explicar, por 
exemplo, um maior uso do planejamento escrito na empresa referencial "Hortifruti", relativamente à empresa referencial "Cana-de-açúcar".

De qualquer forma, o ideal é que o processo de planejamento seja formalizado (por escrito) ou pelo menos que seja praticado ou discutido, cotidianamente, pelo tomador de decisões com os demais membros da família, e com os funcionários da empresa. Essa cotidiana discussão sobre o processo de planejamento é particularmente importante onde há grande envolvimento da mão-de-obra familiar no processo produtivo, como por exemplo, nas empresas referenciais "Café" e "Pequena Produção". A discussão cotidiana sobre o processo de planejamento é importante, também, para questões relacionadas à motivação dos familiares e demais funcionários para o sucesso da empresa no curto prazo e, para o sucesso da empresa no longo prazo, quando da sucessão patrimonial.

É certo que o uso do planejamento possui relação positiva com o sucesso da empresa agropecuária, em termos de sua eficiência, eficácia e efetividade. Para uma empresa, efetividade representa a sua capacidade de coordenação de esforços para atingir seus resultados globais e para poder se manter no ambiente ao longo do tempo. Já a eficiência e/ou eficácia, representam a sua capacidade de utilizar adequadamente os recursos disponíveis (internos e externos à empresa) e atingir os objetivos empresariais. O termo objetivo pode ser entendido como uma situação ou resultado futuro que se pretende atingir ${ }^{49}$. Existem objetivos gerais para toda a empresa e objetivos funcionais para áreas específicas da empresa (produção, finanças, comercialização e recursos humanos).

\footnotetext{
${ }_{49}$ Alguns autores diferenciam os termos objetivos, desafios e metas. Oliveira, 1999; por exemplo, considera: (1) objetivo é o alvo que se pretende atingir; (2) desafio é a quantificação, com prazos definidos, do objetivo estabelecido; (3) meta é a etapa ou passo intermediário para se alcançar determinados objetivos. No presente estudo, não se fará essa distinção por enquanto. Aqui, se estará considerando que o objetivo da empresa agropecuária representa uma composição (como se fosse uma média ponderada) dos objetivos de seus dirigentes.
} 
O Quadro 10 apresenta exemplos de atividades administrativas relacionadas ao planejamento estratégico e operacional da área de finanças em empresas agropecuárias. O Quadro 11, por sua vez, apresenta estimativas sobre o grau de importância (ou relevância) dessas atividades para o sucesso das empresas agropecuárias referenciais. Em nível estratégico, o planejamento das finanças apresenta maior grau de importância nas empresas agropecuárias referenciais "Grãos", "Bovino de Corte", "Hortifruti" e "Pequena Produção" e menor nas empresas "Cana-de-açúcar" e "Frango". Nas primeiras empresas, a maior importância atribuída ao planejamento estratégico das finanças está relacionada ao maior valor dos desembolsos líquidos (capital de giro) necessários para a condução das atividades dessas empresas, relativamente às explorações de cana-de-açúcar e frango, onde os maiores desembolsos são financiados (bancados) com recursos da indústria. No planejamento operacional das finanças, o maior grau de importância atribuído às empresas "Grãos" e "Hortifruti" deve-se, além do alto valor do capital de giro necessário a produção, a maior freqüência de operações de compras de insumos e vendas da produção nessas empresas.

Quadro 10 - Exemplos de atividades administrativas em empresas agropecuárias relacionadas ao planejamento estratégico e operacional das finanças.

\begin{tabular}{|c|c|c|}
\hline $\begin{array}{c}\text { Função } \\
\text { administrativa }\end{array}$ & Exemplos de atividades administrativas \\
\hline $\begin{array}{c}\text { Planejamento } \\
\text { estratégico das } \\
\text { finanças }\end{array}$ & $\Rightarrow$ Projetar o fluxo de caixa das atividades e da empresa como um \\
& todo (incluindo gastos familiares), especificando as origens (fontes) \\
& $\Rightarrow$ Elaborar e analisar a viabilidade de projetos de investimento \\
& para a implantação de novas atividades ou para a \\
& modificação/alteração do atual sistema de produção. & \\
\hline $\begin{array}{c}\text { Planejamento } \\
\text { operacional das } \\
\text { finanças }\end{array}$ & $\Rightarrow$ Elaborar orçamentos para as atividades da empresa. \\
\hline
\end{tabular}


Quadro 11 - Estimativas sobre o grau de importância (ou relevância) do planejamento estratégico e operacional das finanças para o sucesso das empresas agropecuárias referenciais.

\begin{tabular}{|l|c|c|}
\hline \multicolumn{1}{|c|}{ Empresas Referenciais } & $\begin{array}{c}\text { Planejamento estratégico } \\
\text { das finanças }\end{array}$ & $\begin{array}{c}\text { Planejamento operacional } \\
\text { das finanças }\end{array}$ \\
\hline Grãos & 4 & 5 \\
\hline Bovino de Corte & 4 & 2 \\
\hline Cana-de-açúcar & 2 & 3 \\
\hline Café & 3 & 2 \\
\hline Frango & 2 & 5 \\
\hline Hortifruti & 4 & 3 \\
\hline Pequena Produção & 4 & \\
\hline
\end{tabular}

Exemplos de atividades administrativas relacionadas ao planejamento estratégico e operacional da área de comercialização e estimativas sobre o grau de importância dessas atividades são mostradas, respectivamente, nos Quadros 12 e 13. Tanto em nível estratégico, como em nível operacional merece destaque o grau de importância atribuído ao planejamento da comercialização na empresa referencial "Hortifruti". A maior importância de se planejar a comercialização nessa empresa deve: ao grande número de clientes da empresa; aos diversos canais de comercialização utilizados, a maior frequiência de venda da produção; a especificidade, em termos de diferenciação de marca e qualidade, da produção comercializada. Em outro extremo, merece destaque o baixo grau de importância, atribuído ao planejamento da comercialização nas empresas referenciais "Cana-de-açúcar" e "Frango", em função de adotarem o preço médio como principal estratégia de comercialização da produção. 
Quadro 12 - Exemplos de atividades administrativas em empresas agropecuárias relacionadas ao planejamento estratégico e operacional da comercialização.

\begin{tabular}{|c|c|}
\hline $\begin{array}{c}\text { Função } \\
\text { administrativa }\end{array}$ & Exemplos de atividades administrativas \\
\hline $\begin{array}{c}\text { Planejamento } \\
\text { estratégico da } \\
\text { comercialização }\end{array}$ & $\Rightarrow$ Identificar e definir estratégias de comercialização (compras e \\
& vendas) para todas as atividades da empresa. \\
& produtos e definir canais de comercialização. \\
\hline Planejamento & $\Rightarrow$ Estabelecer planos para a comercialização (compras e vendas) \\
operacional da & no curto prazo. \\
comercialização & $\Rightarrow$ Estimar preços futuros de curto prazo para insumos e \\
& produtos.
\end{tabular}

Quadro 13 - Estimativas sobre o grau de importância (ou relevância) do planejamento estratégico e operacional da comercialização para o sucesso das empresas agropecuárias referenciais.

\begin{tabular}{|l|c|c|}
\hline \multicolumn{1}{|c|}{ Empresas Referenciais } & $\begin{array}{c}\text { Planejamento estratégico da } \\
\text { comercialização }\end{array}$ & $\begin{array}{c}\text { Planejamento operacional } \\
\text { da comercialização }\end{array}$ \\
\hline Grãos & 4 & 4 \\
\hline Bovino de Corte & 4 & 1 \\
\hline Cana-de-açúcar & 1 & 4 \\
\hline Café & 3 & 5 \\
\hline Frango & 1 & 3 \\
\hline Hortifruti & 5 & 1 \\
\hline Pequena Produção & 2 & 4 \\
\hline
\end{tabular}


Exemplos de atividades administrativas relacionadas ao planejamento estratégico e operacional da área de pessoal (ou recursos humanos) e estimativas sobre o grau de importância dessas atividades são mostradas, respectivamente, nos Quadros 14 e 15. Tanto em nível estratégico como em nível operacional, merece destaque os graus de importância atribuído ao planejamento do pessoal nas empresas referenciais "Café", "Hortifruti" e "Pequena Produção". A maior importância de se planejar o pessoal nessas empresas deve-se: ao grande número de trabalhadores (fixos e temporários) utilizados nessas empresas, tendo em vista a baixa mecanização de seus sistemas de produção; a significativa participação da mão-de-obra nos custos de produção, a maior importância dos serviços manuais na eficiência de seus sistemas produtivos, e a maior disponibilidade de mão-de-obra familiar nessas empresas. Em outro extremo, merece destaque o baixo grau de importância, atribuído ao planejamento do pessoal nas empresas referenciais "Bovino de Corte" e "Cana-de-açúcar". Na empresa "Bovino de Corte", em função do baixo número de trabalhadores temporários utilizados nessa empresa, tendo em vista a menor demanda por mão-de-obra nessa atividade; e da menor participação da mão-de-obra nos custos de produção dessa atividade. $\mathrm{Na}$ empresa "Cana-de-açúcar", a menor importância do planejamento da mão-de-obra pode ser atribuído ao fato da maioria desses serviços serem executados pela empresa integradora (Usina). 
Quadro 14 - Exemplos de atividades administrativas em empresas agropecuárias relacionadas ao planejamento estratégico e operacional do pessoal.

\begin{tabular}{|c|c|}
\hline $\begin{array}{c}\text { Função } \\
\text { administrativa }\end{array}$ & \multicolumn{1}{c|}{ Exemplos de atividades administrativas } \\
\hline $\begin{array}{c}\text { Planejamento } \\
\text { estratégico do } \\
\text { pessoal }\end{array}$ & $\begin{array}{l}\Rightarrow \text { Estimar o balanço de oferta e demanda de mão-de-obra para a } \\
\text { empresa. } \\
\text { treinamento da mão-de-obra. }\end{array}$ \\
\hline $\begin{array}{c}\text { Planejamento } \\
\text { operacional do } \\
\text { pessoal }\end{array}$ & $\begin{array}{l}\Rightarrow \text { Prever a disponibilidade e exigência de mão-de-obra para as } \\
\text { atividades da empresa. }\end{array}$ \\
& Extabelecer para a mão-de-obra as ações necessárias para a \\
\end{tabular}

Quadro 15 - Estimativas sobre o grau de importância (ou relevância) do planejamento estratégico e operacional do pessoal para o sucesso das empresas agropecuárias referenciais.

\begin{tabular}{|l|c|c|}
\hline \multicolumn{1}{|c|}{ Empresas Referenciais } & $\begin{array}{c}\text { Planejamento estratégico do } \\
\text { pessoal }\end{array}$ & $\begin{array}{c}\text { Planejamento operacional } \\
\text { do pessoal }\end{array}$ \\
\hline Grãos & 3 & 4 \\
\hline Bovino de Corte & 2 & 1 \\
\hline Cana-de-açúcar & 2 & 5 \\
\hline Café & 4 & 4 \\
\hline Frango & 3 & 5 \\
\hline Hortifruti & 4 & 5 \\
\hline Pequena Produção & 4 & 2 \\
\hline
\end{tabular}




\subsubsection{Filosofias do planejamento}

$\mathrm{Na}$ orientação do processo de planejamento para atingir os objetivos empresariais, Ackoff, 1974 (citado por Oliveira, 1999) distingue três filosofias do planejamento: a filosofia da satisfação, a filosofia da otimização e a filosofia da adaptação. Com a filosofia da satisfação, o processo de planejamento tem as seguintes características básicas: (a) geralmente considera um número pequeno de objetivos quantitativos e qualitativos factíveis; (b) os objetivos implicam em fazer "suficientemente bem", mas não necessariamente "tão bem quanto possível"; e (c) os objetivos definidos pelo empresário geralmente são próximos das práticas correntes da empresa e levam em conta, principalmente, restrições de ordem financeira e a preocupação com a sobrevivência ou manutenção da empresa. Já com a filosofia da otimização, o processo de planejamento tem as seguintes características básicas: (1) utilizam modelos de simulação, no sentido de realizar algo "tão bem quanto possível" e não apenas "suficientemente bem"; (2) os objetivos são formulados apenas em termos quantitativos, procurando maximizar o processo decisório das variáveis presentes no modelo. Por fim, com a filosofia da adaptação, o empresário considera que as mudanças no ambiente externo são as principais responsáveis por seus problemas internos. Nesse caso a empresa necessita estar, constantemente, se adequando às mudanças externas, e o processo de planejamento varia conforme as diferentes posturas (passiva, adaptativa, antecipatória, ou auto-estimulada) que a empresa adota frente aos estímulos externos. $\mathrm{Na}$ postura passiva, a empresa muda seu comportamento de forma defasada aos estímulos externos. Na postura adaptativa a empresa procura adaptar-se, em tempo oportuno, aos novos estados do ambiente. Na antecipatória a empresa procura se antecipar às mudanças do meio. E na postura auto-estimulada, há constante busca de novas oportunidades para crescimento e/ou expansão da empresa, à medida que ocorrem as mudanças no meio ambiente. 
Com relação a essas filosofias do processo de planejamento, a filosofia da adaptação parece ser a mais comumente utilizada pelas empresas agropecuárias, pois as constantes transformações nas variáveis do ambiente externo são comuns e muito significativas para o setor agropecuário. Além disso, vale ressaltar, que o tratamento de múltiplos objetivos, que é fato comum nas empresas agropecuárias, dificulta a utilização de modelos de otimização pelos produtores rurais, e o correspondente uso do planejamento da empresa como um todo baseado na filosofia da otimização. Na prática, as principais limitações ao uso de modelos de otimização no planejamento estratégico de empresas agropecuárias estão relacionadas, principalmente, a dificuldades na quantificação de certos objetivos do empresário rural e na escolha de uma ou mais variáveis que possam ser representativas dos múltiplos objetivos gerais da empresa. Não obstante, no caso do planejamento ser direcionado apenas a determinadas áreas ou subsistemas da empresa agropecuária, os modelos de otimização podem se mostrar úteis ao empresário rural. È comum, por exemplo, que o planejamento operacional da produção em algumas empresas agropecuárias seja baseado na filosofia da otimização. Isso normalmente ocorre quando a obtenção de altos índices de produtividade é fundamental para o sucesso da empresa agropecuária, como é o caso das empresas referenciais "Grãos", "Frango" e "Hortifruti". Em um outro extremo, é possível que algumas empresas agropecuárias adotem o planejamento de alguma área empresarial (comercialização, por exemplo) baseado na filosofia da satisfação. Isso normalmente ocorre, quando os preços recebidos pelos produtores representam uma média ponderada, definida pela indústria, como é o caso da comercialização do leite em algumas empresas agropecuárias, do frango na empresa referencial "Frango" e da cana de açúcar na empresa “Cana-de-açúcar”.

$\mathrm{Na}$ realidade, as filosofias de planejamento adotadas nas empresas agropecuárias estão intimamente relacionadas às diferentes estratégias traçadas pelas empresas (sobrevivência, manutenção, crescimento, ou desenvolvimento), e pelo estágio do ciclo de vida que a empresa se encontra (introdução ou infância, crescimento, maturidade ou estabilidade e, declínio ou velhice). No meio agropecuário, por exemplo, 
uma empresa em fase de declínio ou velhice provavelmente adotará estratégias de sobrevivência ou manutenção e um planejamento baseado na filosofia da satisfação ou na filosofia da adaptação com postura passiva ou adaptativa. Já uma outra empresa agropecuária em fase de crescimento, provavelmente adotará uma estratégia de crescimento ou desenvolvimento e um planejamento baseado na filosofia da otimização ou na filosofia da adaptação com postura antecipatória ou auto-estimulada.

A estratégia de sobrevivência ocorre em situações quando, tanto a empresa como o ambiente, estão em situação inadequada, ou seja, quando predominam os pontos fracos na empresa e as ameaças do ambiente. Nessa situação, uma empresa agropecuária poderia tomar as seguintes decisões: paralisação de investimentos; venda ou aluguel para terceiros de ativos fixos; corte generalizado de despesas de custeio (insumos, mão-de-obra e serviços) e de despesas de manutenção dos ativos fixos; abandono de atividades com alto risco de produção e de mercado ou que exijam grandes desembolsos; adoção de postura extrativista no caso de culturas perenes; forte redução dos gastos familiares; entre outras. Se for considerado, por exemplo, que a empresa referencial "Pequena Produção" adota ou precisa adotar a estratégia de sobrevivência ela poderia tomar, especificamente, as seguintes decisões: deslocar parte da mão-de-obra familiar para trabalhar fora da propriedade, dar preferência ao cultivo de lavouras de menor risco econômico para ela (como o milho, por exemplo), adotar postura extrativista na tentativa de reduzir (criteriosamente) despesas de custeio das lavouras e da pecuária de leite, arrendar parte das terras a terceiros, adiar novos investimentos, entre outras.

A estratégia de manutenção ocorre quando a empresa identifica um ambiente com predominância de ameaças e adota uma postura defensiva. No entanto, os pontos fortes da empresa, acumulados ao longo do tempo, possibilitam a ela manter a situação competitiva conquistada até o momento. Nessa situação, uma empresa agropecuária poderia tomar as seguintes decisões: manter baixo o nível de investimentos; focar seus negócios em atividades de baixo risco de produção e de 
mercado; reduzir um pouco as despesas de custeio, manutenção de ativos e familiares; entre outras. Se for considerado, por exemplo, que a empresa referencial "Bovino de Corte" adota ou precisa adotar a estratégia de manutenção ela poderia tomar, especificamente, as seguintes decisões: adiar a reforma de pastagens, adiar a recuperação de benfeitorias e a realização de novos investimentos; equilibrar os gastos da propriedade e da família às rendas geradas pelo crescimento e engorda do rebanho de forma a mantê-lo pelo menos estável ao longo do tempo; arrendar pastos ociosos a terceiros, entre outras.

A estratégia de crescimento normalmente ocorre quando há predominância dos pontos fortes da empresa e ela consegue se beneficiar de algumas oportunidades do ambiente. Nessa situação, uma empresa agropecuária poderia tomar as seguintes decisões: ampliar investimentos na produção; ampliar o volume dos negócios existentes; adquirir ou arrendar novas áreas; melhorar o padrão de vida familiar; entre outras. Se for considerado, por exemplo, que a empresa referencial "Grãos" adota ou pretende adotar a estratégia de crescimento ela poderia tomar, especificamente, as seguintes decisões: adquirir novas máquinas e equipamentos ou reformar as existentes; investir em benfeitorias e na correção do solo; ampliar a área de cultivo por meio de parcerias ou arrendamento de novas áreas; almejar níveis máximos de produtividade pela adoção integral da tecnologia disponível; entre outras.

A estratégia de desenvolvimento ocorre em situações onde há forte predominância dos pontos fortes da empresa e de oportunidades no ambiente. Nessa situação, uma empresa agropecuária poderia tomar as seguintes decisões, além das já relacionadas na estratégia de crescimento: ampliar investimentos em ativos fixos (infraestrutura); iniciar novas atividades produtivas (diversificação); perseguir níveis máximos de produtividade e qualidade no processo produtivo; otimizar a alocação de recursos físicos, financeiros, mercadológicos e humanos; conquistar diferenciações de marca e qualidade de sua produção; consolidar alianças com clientes e fornecedores que proporcionem vantagem competitiva ou efeitos sinérgicos positivos; entre outras. Se for 
considerado, por exemplo, que a empresa referencial "Hortifruti" adota ou pretende adotar a estratégia de desenvolvimento ela poderia tomar, especificamente, as seguintes decisões: adquirir máquinas e equipamentos mais sofisticados; melhorar a qualidade da produção; otimizar o resultado econômico (maximizar lucro), conquistar novos clientes; entre outras.

\subsubsection{Técnicas de planejamento}

Para a realização formal do planejamento estratégico, o produtor rural deve identificar as atividades (ou alternativas) potenciais a serem realizadas, avaliar as conseqüências futuras dessas alternativas, elaborar um plano de trabalho e decidir pela realização de uma ou mais das alternativas em estudo. No processo de planejamento estratégico, o produtor rural considera fatores como: (a) as disponibilidades dos recursos físicos, financeiros, humanos e mercadológicos da empresa e, as correspondentes exigências desses recursos pelas alternativas em análise; (b) os pontos fortes e fracos do ambiente interno da empresa; (c) as ameaças e as oportunidades do ambiente externo; (d) os riscos e as rentabilidades potenciais de cada alternativa; (e) os gostos e as preferências pessoais e da família; entre outros. Quanto maior for a variabilidade potencial desses fatores, maior será o risco na tomada de decisão e mais freqüente será a necessidade de revisão do processo de planejamento adotado na empresa.

Dentre os métodos (ou técnicas) de avaliação econômica, mais comumente $^{50}$ utilizados para se identificar à viabilidade de mudanças em sistemas de produção na agropecuária, destacam-se: (a) a técnica da orçamentação de atividades,

\footnotetext{
${ }^{50}$ Outros métodos ou técnicas de planejamento poderiam ser citados e discutidos, como por exemplo, a programação linear, o PERT/CPM, entre outros. Sobre a programação linear, cabe ressaltar seu baixo uso na agropecuária brasileira por limitações de conhecimento e habilidades dos usuários, à exceção de alguns usos específicos como na formulação de rações de custo mínimo, entre outros. Além disso, o uso restrito da programação linear na agropecuária também ocorre pela sua baixa praticidade em situações onde existam poucas alternativas de produção, como é o caso da maioria das empresas agropecuárias já estabelecidas. No caso do PERT/CPM ou método do caminho crítico, sua principal limitação de uso na empresa agropecuária está relacionada a dificuldades em se prever o tempo exato (eficiência de campo) para a execução das tarefas ou serviços operacionais.
} 
utilizada principalmente quando se pretende comparar a razão benefício/custo de diferentes explorações agropecuárias que possuem tempo de produção semelhante; (b) a técnica da orçamentação parcial, utilizada principalmente quando se pretende comparar duas alternativas mutuamente exclusivas (mudança tecnológica) que proporcionam alterações nos fluxos futuros de receitas e despesas do empreendimento agropecuário; (c) a técnica de análise de investimentos utilizada para avaliar projetos de implantação (seleção de projetos) ou projetos de alteração no sistema de produção (projetos de fluxo incremental). Na avaliação comparativa de projetos de implantação (seleção de projetos), geralmente analisa-se um a um os vários projetos alternativos, e por comparação, seleciona-se aquele de maior viabilidade econômica. Na avaliação de projetos de fluxo incremental, utilizada quando a mudança tecnológica proposta altera parcialmente o sistema de produção, geralmente analisa-se o fluxo líquido de caixa proporcionado pela mudança, e assim, aceita-se ou não as alterações propostas.

A seguir, faz-se uma breve apresentação e discussão sobre os referidos métodos (ou técnicas) de avaliação econômica, procurando destacar a importância da avaliação de cenários a fim de auxiliar o tomador de decisão no processo de planejamento da empresa agropecuária ${ }^{51}$. Aqui, com a avaliação de cenários, pretende-se desmistificar a idéia de que o planejamento escrito só deva ser realizado na empresa agropecuária quando se destina a terceiros (por exemplo, uma instituição financeira). Pela ordem, serão discutidos os seguintes métodos: (a) orçamentação de atividades; (b) orçamentação parcial e (c) análise de investimento.

\footnotetext{
$\overline{51}$ Algumas publicações do autor apresentam exemplos numéricos de avaliação econômica de empresas agropecuárias, incorporando a avaliação de cenários. É o caso, por exemplo, das seguintes publicações, que apresentam análises para empresas que exploram a bovinocultura de corte: (1) CANZIANI, J. R \& DOSSA, D. In: SERVIÇO NACIONAL DE APRENDIZAGEM RURAL: Administração Regional do Paraná. Avaliação Técnica e Econômica da Bovinocultura de Corte. Curitiba, 2000. 42 p.; (2) CANZIANI, J.R. Análise Econômica na Pecuária de Corte. In: CONGRESSO BRASILEIRO DE ECONOMIA E SOCIOLOGIA RURAL. Recife, 2001. Anais. (no prelo).
} 


\section{(a) Orçamentação de atividades}

Dentre os métodos de cálculo que auxiliam o processo de planejamento, a orçamentação de atividades é um dos métodos mais comumente utilizados, de maneira formalizada (por escrito), no setor agropecuário do país. O método (ou técnica) da orçamentação de atividades envolve a elaboração de projeções sobre receitas e despesas de custeio. Ele contempla, portanto, atividades administrativas relacionadas a diferentes áreas funcionais: (1) na área de produção faz-se estimativas sobre coeficientes técnicos de rendimento operacional, de uso de insumos, de produtividades, entre outros; (2) nas áreas de finanças e comercialização faz-se, por exemplo, estimativas de preços de insumos, produtos e serviços; (3) na área de pessoal faz-se estimativas sobre o rendimento e o custo da mão-de-obra.

A grande difusão e adoção desse método no setor agropecuário do país, principalmente a partir da década de 70, deve-se à obrigatoriedade de sua realização, por escrito, para a obtenção de financiamentos de custeio com recursos do crédito rural. Cabe ressaltar, entretanto, que as normas para a concessão do crédito rural no Brasil, no que diz respeito à realização de orçamentos de atividades, tiveram algumas alterações importantes nas últimas duas décadas. Até o início dos anos 90, o governo federal, através da Companhia de Financiamento da Produção - CPF e depois da Companhia Nacional de Abastecimento - CONAB que a sucedeu, elaborava orçamentos básicos para algumas culturas e os divulgava através dos chamados Valores Básicos de Custeio - VBCs. Os VBCs, para cada cultura, variavam conforme os níveis esperados de produtividade das lavouras e das regiões do país. Esses valores (estimativas) divulgados pelo governo, no entanto, eram freqüentemente alvos de críticas por parte das instituições de representação dos produtores. Essas instituições, interessadas no repasse do maior volume de crédito rural possível aos produtores rurais, normalmente julgavam os VBCs subestimados para a "realidade" da classe produtora. 
Em meados da década de 90, a política de estabelecimento dos VBCs foi abandonada pelo governo federal. Em seu lugar, passou a vigorar no âmbito do crédito rural brasileiro uma maior liberdade, para os profissionais da assistência técnica, elaborarem os orçamentos individuais para cada produtor, respeitando-se, porém, um limite máximo no valor do financiamento por cultura. Na elaboração dos orçamentos, ainda hoje, os profissionais da assistência técnica não possuem grande liberdade de ação, pois as instituições financeiras ainda sugerem ou determinam, regionalmente, os valores de alguns itens que compõem os orçamentos de custeio para as lavouras, principalmente os valores relacionados às operações mecanizadas de preparo do solo, tratos culturais e colheita. Apesar desses avanços, a elaboração de orçamentos de atividades agropecuárias no Brasil, ainda continua direcionada muito mais ao cumprimento de uma formalidade exigida para a obtenção de financiamentos, do que propriamente um método de apoio ao processo de planejamento operacional das atividades das propriedades rurais. Corrobora, nesse sentido: (a) o fato de a maioria dos produtores realizar apenas um único orçamento para a área cultivada a ser financiada, em cada instituição financeira; (b) o freqüente uso de valores médios regionais na definição das estimativas de gastos por unidade de área, independente da infra-estrutura de cada produtor rural; (c) o uso predominante de preços conservadores (preços mínimos, por exemplo), exigidos pelas instituições financeiras, para a estimativa de receita e de capacidade de pagamento das atividades a serem financiadas.

Sob a ótica da administração da empresa agropecuária, a elaboração de orçamentos de atividades é uma técnica indispensável para o planejamento da produção. Para um uso mais eficiente da técnica da orçamentação de atividades na gestão da empresa agropecuária, alguns procedimentos deveriam ser mais considerados. Dentre eles, pode-se destacar: (a) o número de orçamentos gerenciais, a serem elaborados no âmbito das empresas agropecuárias, deveria ser equivalente ao número dos talhões que o produtor rural pretende controlar e avaliar separadamente; (b) nos orçamentos deveriam ser consideradas estimativas as mais próximas possíveis da realidade de cada produtor, e não de números médios regionais; (c) nas estimativas de receita deveriam ser 
considerados diferentes cenários, tanto para os preços do produto como para as produtividades esperadas. Um bom número para a simulação de cada variável é três, compondo-se, nesse caso, cenários denominados otimista, normal e pessimista; (d) a etapa de análise dos diferentes orçamentos elaborados deveria conter o cálculo de produtividades e preços de nivelamento (ou de equilíbrio) para cada um dos cenários projetados.

\section{(b) Orçamentação parcial}

A técnica da orçamentação parcial é freqüentemente utilizada em avaliações econômicas para a tomada de decisão na empresa agropecuária, quando se pretende comparar a economicidade de duas alternativas mutuamente exclusivas. Por exemplo, uma situação ou alternativa "A" versus uma situação ou alternativa "B". Considerando que a alternativa "A" represente a situação atual e, a alternativa "B" a situação proposta, normalmente utiliza-se a orçamentação parcial para se saber sobre a viabilidade econômica de se passar de "A" para "B". Ou seja, pretende-se saber, com a orçamentação parcial, se os ganhos líquidos são positivos com a adoção da situação proposta. A passagem de "A" para "B" pode gerar ganhos (benefícios) e/ou perdas (custos). Os ganhos, proporcionados pela mudança podem ocorrer através de aumentos de receita e/ou de reduções de custos. As perdas, por sua vez, podem ocorrer através de reduções de receitas e/ou aumento de custos. O esquema, abaixo, ilustra as possibilidades de ganhos e perdas.

Alternativa A: situação atual

Alternativa B: situação proposta

Ganhos com a passagem de A para B:

- Aumento de receitas

- Reduções de custos

Perdas com a passagem de A para B:

- $\quad$ Aumento de custos

- Reduções de receitas 
Em termos de resultado, a alternativa $\mathrm{B}$ é preferível à alternativa $\mathrm{A}$ quando os ganhos, decorrentes da mudança, superam as perdas, ou seja, quando o ganho líquido é positivo. Na igualdade entre ganhos e perdas tem-se o ponto de equilíbrio ou nivelamento, e uma conseqüente situação de indiferença entre as duas alternativas. A identificação quantitativa do ponto de equilíbrio e, a sua respectiva sensibilidade às variações dos parâmetros considerados em seu cálculo, corresponde a uma importante informação auxiliar ao processo de tomada de decisão na empresa agropecuária. Se pequenas alterações nos parâmetros utilizados no cálculo proporcionam grandes alterações no ponto de equilíbrio, a adoção da situação proposta envolve grande incerteza, e vice-versa.

$\mathrm{Na}$ incerteza sobre o exato valor dos custos adicionais e/ou dos benefícios adicionais proporcionados por alterações na tecnologia utilizada na empresa agropecuária, uma boa opção é avaliar economicamente as alternativas em estudo, sob diferentes cenários. A metodologia de se trabalhar com cenários na orçamentação parcial permitem incorporar, de forma simplificada, o risco na avaliação econômica de empreendimentos agropecuários, e assim: (1) propiciar a identificação da sensibilidade dos retornos esperados, dada à ocorrência de variações em coeficientes técnicos, índices de produtividade, preços de insumos e produtos, etc. (2) proporcionar decisões com maior nível de certeza.

\section{(c) Análise de investimentos}

Todo projeto apresenta fluxos de entrada e saída de recursos. A diferença entre estes fluxos é chamada de fluxo líquido ou de entradas líquidas de caixa. Sobre o fluxo líquido aplicam-se as técnicas de desconto para calcular a rentabilidade presente (ou atual) dos investimentos. Dentre os critérios de avaliação de projetos, os métodos que consideram a dimensão tempo dos valores monetários são mais precisos, pois o valor do dinheiro não permanece constante ao longo do tempo, ou seja, raramente o custo de oportunidade do capital é zero. Assim, uma vez conhecida a taxa de desconto relevante para uma empresa ou projeto, denominada custo médio ponderado do capital 
da empresa (CMPC) ou custo médio ponderado do capital do projeto, pode-se transformar valores que ocorrem em datas diferentes em valores expressos em uma mesma data base. Com esse procedimento os valores de um fluxo de caixa tornam-se comparáveis, tornando possível a avaliação de projetos de implantação (seleção de projetos) ou a avaliação de projetos que alteram parcialmente o sistema de produção (projetos de fluxo incremental) $^{52}$. Os principais métodos para a avaliação do fluxo líquido de projetos são: (1) VPL (valor presente líquido), VPLA (valor presente líquido anualizado), TIR (taxa interna de retorno), relação B/C (relação benefício/custo) e o PRC (período de recuperação do capital) utilizados na avaliação de projetos de implantação; e (2) TRF (taxa de retorno de Fischer) utilizada na avaliação de projetos de fluxo incremental.

$\mathrm{Na}$ agropecuária, a análise de investimentos para subsidiar o processo de tomada de decisões, geralmente possui particularidades inerentes a cada atividade. Essas particularidades precisam ser devidamente consideradas, principalmente quando se pretende identificar a viabilidade econômica de mudanças no sistema de produção (projetos de fluxo incremental), a fim de se evitar erros na formulação do problema em

\footnotetext{
${ }^{52}$ Segundo Noronha (1987) as alternativas de investimento em uma determinada atividade agropecuária, raramente são totalmente independentes entre si. Porém, para efeito de avaliações econômicas, quando o grau de interação (influência de um projeto sobre o fluxo de caixa de outro projeto) é pequeno, pode-se considerar que os projetos são independentes. Quando, por outro lado, a implantação de um projeto impede a do outro, diz-se que os projetos são mutuamente exclusivos ou substitutos perfeitos. Entre os dois extremos, na prática há muitos graus de complementaridade entre projetos. Quando determinado projeto é independente dos demais, tanto o critério do VPL como da TIR permite chegar consistentemente à mesma decisão final, assumindo que a TIR exista e seja única. Entretanto, quando dois projetos são mutuamente exclusivos, os dois métodos de análise (TIR e VPL) nem sempre indicam a mesma escolha. Entre os métodos que usam fatores de desconto, o VPL é mais preciso do que os demais, na maioria dos casos. Entretanto, é preciso reconhecer que a TIR é bem mais atrativa como método de análise, pois sua interpretação, por ser uma porcentagem de crescimento, é mais fácil e cômoda. De qualquer forma, seja qual for o método de avaliação adotado, é necessário considerar ainda as seguintes dificuldades adicionais na seleção de projetos alternativos: diferentes volumes de investimentos; horizontes diferentes; diferenças nos períodos de implantação, e diferenças dos níveis de risco dos projetos alternativos, entre outras. Noronha (1987) afirma ainda que, na prática, as empresas rurais dificilmente terão problemas de escolha entre uma série de projetos alternativos ao mesmo tempo. Em geral, as decisões de investimento são feitas, por um lado, na forma de pequenos projetos destinados a modificar parcialmente a organização da empresa. Por outro lado, os grandes projetos normalmente compõem-se de um conjunto de atividades complementares. Em vez de muitos projetos competitivos tem-se de fato um único projeto, que pode ou não ser redimensionado dependendo dos recursos disponíveis e das condições da empresa.
} 
estudo e na interpretação dos resultados. Na maioria das vezes, a maior dificuldade em estimar o fluxo de caixa de um projeto dessa natureza é isolar ou separar adequadamente o problema em estudo, dada a ampla variedade de fatores inter-relacionados que compõem o sistema de produção. Nesse sentido, é comum na formulação de problemas econômicos na agropecuária, a super ou sub-avaliação dos custos e/ou dos benefícios adicionais proporcionados exclusivamente pelas alterações no sistema de produção, vis a vis, a situação anterior às mudanças. Essas dificuldades na formulação e avaliação de projetos de fluxo incremental ocorrem, também, pela dificuldade em se extrapolar com precisão os resultados das pesquisas (tecnológicas) de campo e pela, em geral, ausência de correspondentes avaliações econômicas na divulgação dos resultados dessas pesquisas. Um procedimento metodológico interessante, na tentativa de se isolar o problema econômico em estudo, é avaliar, separadamente ${ }^{53}$, as situações com e sem a mudança tecnológica proposta e, por diferença de valores, estimar os benefícios adicionais e os custos adicionais proporcionados pela alteração tecnológica. Normalmente, a avaliação em separado das duas situações facilita a identificação das variáveis que realmente se alteram, com a incorporação da nova tecnologia.

Para minimizar as incertezas na estimativa das variáveis que compõe o projeto, aqui também, uma boa opção é se valer de diferentes cenários, transformando as estimativas em um intervalo, ao invés de um ponto. Isso permitiria que os resultados prováveis fossem expressos também em um intervalo proporcionando decisões com maior nível de certeza. Lamentavelmente, ainda é pouco freqüente o uso da análise de investimento em projetos de fluxo incremental nas empresas agropecuárias.

\footnotetext{
${ }^{53}$ Um princípio fundamental na avaliação de projetos é a correta construção dos fluxos de caixa. Isso significa que devem ser considerados no projeto apenas as receitas e despesas que podem ser atribuídas diretamente à decisão de implementá-lo. Assim, aquelas despesas e receitas que a empresa teria necessariamente de fazer ou receber, na ausência do projeto, são irrelevantes para a formação dos fluxos de caixa. Na agropecuária, como as decisões de investimento normalmente estão relacionadas às alterações de um sistema de produção já em andamento, às vezes é mais fácil construir dois fluxos de caixa (com e sem as alterações) e, por diferença, avaliar o fluxo líquido resultante, através da Taxa de Retorno de Fischer (TRF). Por definição, a TRF é o valor da taxa de desconto que iguala o VPL das duas alternativas (por exemplo, A e B) em análise. Para taxas de desconto (ou CMPC) acima ou abaixo da TRF, uma alternativa (A ou B) será preferível à outra, e vice versa, sendo possível a seleção de projetos mutuamente exclusivos.
} 
Normalmente, a elaboração e avaliação de projetos agropecuários visam, muito mais, cumprir formalidades junto às instituições financeiras (como, por exemplo, comprovar a capacidade de pagamento da empresa), do que servir como instrumento auxiliar ao processo de tomada de decisões. A melhoria de conhecimentos, habilidades e atitudes, por parte dos produtores e dos profissionais da assistência técnica, visando à correta aplicação das técnicas de avaliação econômica, pode minimizar as incertezas vinculadas ao processo de tomada de decisões nas empresas agropecuárias.

\subsection{A organização nas empresas agropecuárias referenciais.}

A organização abrange as atividades administrativas realizadas para se estruturar e agrupar adequadamente os recursos físicos, financeiros, mercadológicos e humanos da empresa. Daí resulta a classificação adotada nesse trabalho, que abrange: a organização da produção, das finanças, da comercialização e do pessoal.

Normalmente, as ações administrativas voltadas a organizar os recursos da empresa sucedem as ações de planejamento e antecedem as ações de direção e de controle. Na organização da produção, por exemplo, a correta disposição dos campos e das benfeitorias normalmente é estabelecida após a decisão do que e como produzir, mas antecede o início propriamente dito do processo produtivo e, conseqüentemente o controle desse processo.

O quadro 16 apresenta vários exemplos de atividades administrativas relacionadas à organização estratégica e operacional da produção, finanças, comercialização e pessoal. Considerando a finalidade dessas atividades administrativas, pode-se distinguir três grandes grupos: (a) as atividades destinadas a organizar os recursos físicos (capitais fixos e circulantes) da empresa que compõem a organização física; (b) as atividades destinadas a organizar os recursos humanos (organogramas funcionais, planos de cargos e salários, entre outras) que compõem a organização do 
pessoal e; (c) as atividades destinadas a organizar o fluxo de informações gerenciais da empresa (cadastros, plano de contas, entre outras) que compõem a organização gerencial.

Praticamente todos os empresários almejam possuir empresas bem organizadas. A organização física é a mais aparente, e por isso tem recebido, nas últimas décadas, maior atenção dos empresários rurais. Nas empresas agropecuárias, esse tipo de organização exige longo tempo e altos investimentos para se materializar, mas ao final proporcionam além de ganhos na eficiência produtiva, melhorias de imagem (status) ao empresário rural. Mais recentemente, a organização gerencial tem sido almejada por muitos empresários rurais, não por um desejo pessoal, mas pela necessidade imposta pelas mudanças macroeconômicas, que tem exigido maior eficiência gerencial das empresas agropecuárias. A informática tem contribuído nesse processo, mas os softwares existentes no mercado ainda não atendem perfeitamente a demanda dos produtores rurais, conforme exposto anteriormente no item 5.2.2. 
Quadro 16 - Exemplos de atividades administrativas em empresas agropecuárias relacionadas à organização estratégica e operacional das áreas administrativas.

\begin{tabular}{|c|c|}
\hline $\begin{array}{l}\text { Função } \\
\text { administrativa }\end{array}$ & Exemplos de atividades administrativas \\
\hline $\begin{array}{l}\text { Organização } \\
\text { estratégica da } \\
\text { produção }\end{array}$ & $\begin{array}{l}\Rightarrow \text { Dispor, ordenadamente, a exploração dos campos e a localização das } \\
\text { benfeitorias na empresa. } \\
\Rightarrow \text { Definir sobre as formas de organização da produção na empresa } \\
\text { (individual, societária, parceria, arrendamento, etc.). }\end{array}$ \\
\hline $\begin{array}{l}\text { Organização } \\
\text { operacional da } \\
\text { produção }\end{array}$ & $\begin{array}{l}\Rightarrow \text { Organizar e sistematizar o uso cotidiano dos capitais fixos e circulantes da } \\
\text { empresa. } \\
\Rightarrow \text { Definir sobre a contratação de serviços de terceiros. }\end{array}$ \\
\hline $\begin{array}{l}\text { Organização } \\
\text { estratégica das } \\
\text { finanças }\end{array}$ & $\begin{array}{l}\Rightarrow \text { Definir os centros de custos e/ou centros de lucros da empresa. } \\
\Rightarrow \text { Definir e detalhar o plano de contas da empresa. }\end{array}$ \\
\hline $\begin{array}{l}\text { Organização } \\
\text { operacional das } \\
\text { finanças }\end{array}$ & $\begin{array}{l}\Rightarrow \text { Organizar e sistematizar o fluxo de informações financeiras da empresa. } \\
\Rightarrow \text { Definir a forma de armazenamento de dados e de processamento das } \\
\text { informações financeiras. }\end{array}$ \\
\hline $\begin{array}{l}\text { Organização } \\
\text { estratégica da } \\
\text { comercialização }\end{array}$ & $\begin{array}{l}\Rightarrow \text { Definir e sistematizar as estratégias de compra de insumos e outros fatores } \\
\text { de produção. } \\
\Rightarrow \text { Definir e sistematizar as estratégias para a venda da produção. }\end{array}$ \\
\hline $\begin{array}{l}\text { Organização } \\
\text { operacional da } \\
\text { comercialização }\end{array}$ & $\begin{array}{l}\Rightarrow \text { Organizar sistemas para a identificação e seleção de clientes e de } \\
\text { fornecedores de bens e serviços. } \\
\Rightarrow \text { Organizar sistemas para o acompanhamento de preços no tempo e no } \\
\text { espaço. }\end{array}$ \\
\hline $\begin{array}{l}\text { Organização } \\
\text { estratégica do } \\
\text { pessoal }\end{array}$ & $\begin{array}{l}\Rightarrow \text { Estabelecer o organograma funcional (atribuições) da mão-de-obra, } \\
\text { indicando a interdependência e a hierarquia entre as pessoas, secções ou áreas } \\
\text { de responsabilidades existentes na empresa. } \\
\Rightarrow \text { Estabelecer planos de cargos e salários para a mão-de-obra. }\end{array}$ \\
\hline $\begin{array}{l}\text { Organização } \\
\text { operacional do } \\
\text { pessoal }\end{array}$ & $\begin{array}{l}\Rightarrow \text { Distribuir adequadamente no tempo e no espaço as tarefas da mão-de-obra. } \\
\Rightarrow \text { Estabelecer responsabilidades cotidianas e padrões de desempenho para a } \\
\text { mão-de-obra. }\end{array}$ \\
\hline
\end{tabular}


A organização gerencial na empresa agropecuária, que envolve o estabelecimento de plano de contas, de centros de custos, de cadastros e registros de informações, entre outros, tem sido tratada de forma dispersa na literatura, em textos de contabilidade e administração. No primeiro caso, os textos normalmente se direcionam para a contabilidade tradicional (por partidas dobradas), que seguem os princípios da contabilidade definidos em lei ${ }^{54}$, e que é pouco utilizada nas empresas agropecuárias brasileiras, pela sua relativa complexidade e pela natureza familiar dessas empresas. No segundo caso, os textos sobre a organização gerencial são superficiais ou trazem orientações adaptadas ao uso de softwares específicos. Neste aspecto, importantes questões precisam ser mais bem estudadas no futuro, tais como: a relação benefício/custo de sistemas de informações gerenciais mais ou menos detalhados; os motivos que levam muitos produtores rurais a abandonarem o uso de softwares adquiridos por eles; a viabilidade técnica e econômica do estabelecimento de sistemas de informações gerenciais de forma individual para cada produtor ou de forma comum para empresas agropecuárias semelhantes; entre outras.

\subsubsection{Relevância da organização}

O Quadro 17, que reproduz parte do Quadro 7 no intuito de facilitar sua visualização, apresenta estimativas sobre o grau de importância da organização estratégica e operacional para o sucesso das empresas agropecuárias referenciais. Os dados mostram que na maioria das empresas referenciais a organização da produção é tão ou mais importante do que a organização das demais áreas administrativas. Na agricultura, a importância da organização da produção está relacionada à maior

\footnotetext{
$\overline{54}$ Os procedimentos adotados pela contabilidade fiscal, em partidas dobradas, permitem um eficiente acompanhamento dos resultados financeiros da empresa, mas apresentam alguns inconvenientes, tais como: (a) dependem de profissional habilitado (no caso, um contador); (b) limitam-se a controles monetários, não englobando controles físicos (de quantidade); (c) são direcionados para minimizar o recolhimento de impostos, o que torna inconveniente o registro de informações a valores de mercado, distorcendo análises de lucratividade (lucro sobre as vendas), rentabilidade (lucro sobre o patrimônio), retorno sobre investimentos (lucro sobre determinado investimento ou ativo), margem de contribuição (receita menos custo variável), entre outros.
} 
necessidade de se organizar: (a) o uso do solo, a fim de permitir a execução de planos para melhorar a sua fertilidade e dos planos de sucessão e rotação de culturas; (b) o manejo integrado de pragas e doenças e o controle de plantas daninhas; e (c) a logística que envolve o uso cotidiano dos capitais fixos e circulantes da empresa; entre outros. $\mathrm{Na}$ pecuária, a importância da organização da produção está relacionada à maior necessidade de se organizar a disposição espacial das benfeitorias, dos animais, das pastagens, dos alimentos, entre outros

Além da organização da produção, merecem destaque pelo seu grau de importância: a organização estratégica e operacional da comercialização nas empresas "Hortifruti" e "Bovino de Corte"; a organização operacional das finanças nas empresas "Hortifruti" e "Grãos" e a organização operacional da mão-de-obra nas empresas "Café”, "Frango", "Hortifruti” e "Pequena Produção".

\subsection{A direção nas empresas agropecuárias referenciais.}

A direção compreende o ato de comandar, gerir ou dirigir uma empresa. A direção envolve, além de processos racionais de gestão, também desejos, convicções, gostos e interesses pessoais dos dirigentes. Cabe aos dirigentes exercer a liderança na empresa, motivar sua equipe de trabalho e tomar decisões. A liderança situacional nas empresas agropecuárias pode ser exercida através de comportamentos variados dos dirigentes, quais sejam: comportamento autocrático (quando as decisões são unilateralmente tomadas pelo dirigente, que exige dos subordinados um rígido cumprimento das ordens); comportamento democrático (quando as decisões são compartilhadas, após discussão e analise conjunta do problema pelo dirigente e subordinado); e comportamento indiferente (quando as decisões são tomadas pelos liderados, à revelia do dirigente). 
Quadro 17 - Estimativas sobre o grau de importância (ou relevância) da organização estratégica e operacional para o sucesso das empresas agropecuárias referenciais (escala de 1 a 5) 1.

\begin{tabular}{|c|c|c|c|c|c|c|c|}
\hline Atividades administrativas & $\begin{array}{c}\text { EMPRESA } \\
\text { GRÃOS }\end{array}$ & $\begin{array}{c}\text { EMPRESA } \\
\text { BOVINO } \\
\text { DE CORTE }\end{array}$ & \begin{tabular}{ll}
\multicolumn{2}{c|}{ EMPRESA } \\
8 & CANA- \\
& DE- \\
& AÇÚCA \\
& R \\
\end{tabular} & $\begin{array}{c}\text { EMPRESA } \\
\text { CAFÉ }\end{array}$ & $\begin{array}{c}\text { EMPRESA } \\
\text { FRANGO }\end{array}$ & $\begin{array}{c}\text { EMPRESA } \\
\text { HORTIFRUTI }\end{array}$ & $\begin{array}{c}\text { EMPRESA } \\
\text { PEQUENA } \\
\text { PRODUÇÃO }\end{array}$ \\
\hline Organização estratégica da produção & 4 & 4 & 2 & 3 & 2 & 4 & 4 \\
\hline Organização estratégica das finanças & 3 & 3 & 2 & 3 & 2 & 4 & 3 \\
\hline Organização estratégica da comercialização & 3 & 4 & 1 & 3 & 1 & 5 & 2 \\
\hline Organização estratégica do pessoal & 3 & 2 & 1 & 3 & 3 & 3 & 3 \\
\hline Organização operacional da produção & 5 & 3 & 2 & 4 & 2 & 5 & 5 \\
\hline Organização operacional das finanças & 4 & 3 & 2 & 3 & 2 & 5 & 2 \\
\hline Organização operacional da comercialização & 3 & 4 & 1 & 3 & 1 & 5 & 3 \\
\hline Organização operacional do pessoal & 3 & 2 & 1 & 4 & 4 & 4 & 4 \\
\hline
\end{tabular}

${ }^{1}$ Os números no interior do Quadro indicam o grau de importância das atividades administrativas, sendo que o número 5 representa um grau muito alto de importância e o número 1 um grau baixo de importância. 
No nível estratégico das empresas agropecuárias, geralmente prevalece a liderança autocrática, principalmente pelo baixo nível cultural dos funcionários dessas empresas e pelo organograma funcional, que estabelece que o comando da empresa é centralizado no produtor rural. No nível operacional, no entanto, encontram-se presentes todos os tipos de liderança situacional na empresa agropecuária. A liderança autocrática normalmente ocorre quando é necessário que se cumpra com rigor uma determinada seqüência de tarefas. A liderança democrática normalmente quando as tarefas são flexíveis, existindo formas alternativas para a sua realização, ou ainda, quando os funcionários detêm informações importantes para subsidiar as decisões. A liderança indiferente também ocorre, pois nem sempre é possível a presença do dirigente nos diferentes locais de trabalho na propriedade rural.

Na direção estratégica e operacional dos recursos humanos, a motivação dos trabalhadores é vital para a empresa agropecuária. A motivação pode ser entendida como um conjunto de forças e energias internas do indivíduo que o mantém direcionado a agir de determinada forma. Na empresa agropecuária o processo de motivação, engloba também o estabelecimento de padrões de comportamento e de desempenho, a fim de direcionar e estimular os indivíduos (funcionários e membros da família) a agirem conforme os objetivos estratégicos e funcionais da empresa. Na empresa agropecuária destacam-se os seguintes fatores motivacionais mais importantes para os trabalhadores: salário, benefícios indiretos (moradia, alimentação, lazer, etc) e o reconhecimento pelo trabalho desenvolvido. Em segundo plano, destacam-se: o gosto pela tarefa desenvolvida, a natureza do trabalho e o convívio social. Com menor importância ou em casos mais raros, destacam-se os seguintes fatores motivacionais para os trabalhadores: a possibilidade de ascensão hierárquica, a auto-realização, a segurança no trabalho, o status e o desenvolvimento pessoal.

O quadro 18 apresenta vários exemplos de atividades administrativas relacionadas à direção estratégica e operacional da produção, finanças, comercialização e pessoal. Na área de produção, por exemplo, faz-se à supervisão do processo produtivo, 
a determinação dos serviços a serem realizados nessa área administrativa, entre outras. Nas finanças, a direção envolve a gestão do fluxo de caixa da empresa (uso e aplicações dos recursos financeiros). Na comercialização, o dirigente decide sobre compras e vendas e estabelece critérios de comunicação com clientes e fornecedores. Por fim, na área de pessoal, a direção da empresa agropecuária engloba, por exemplo, a motivação dos trabalhadores, a transmissão das ordens de serviço e o monitoramento das tarefas realizadas.

\subsubsection{Relevância da direção}

A exemplo do observado com o planejamento e a organização, as atividades administrativas de direção exercidas na área de produção, normalmente também são mais importantes do que aquelas realizadas nas outras áreas administrativas. O Quadro 19 apresenta estimativas sobre o grau de importância da direção estratégica e operacional para o sucesso das empresas agropecuárias referenciais. À exceção das empresas "Bovino de Corte" e "Cana-de-açúcar", onde é menor a demanda por mão-deobra e menos complexo o processo produtivo, a direção operacional da produção possui importância muito alta (grau 5) em todas as demais empresas referenciais. Isso, indiretamente, representa a grande importância da presença física do produtor rural ou outra pessoa responsável junto aos serviços operacionais de produção e também a importância de seu conhecimento e habilidade sobre o processo produtivo.

Além da direção da produção, merecem destaque pelo seu grau de importância: a direção estratégica e operacional das finanças nas empresas "Hortifruti" e "Grãos"; a direção estratégica da comercialização nas empresas "Hortifruti" e "Bovino de Corte"; a direção operacional da comercialização nas empresas "Grãos", "Bovino de Corte", "Café" e "Hortifruti"; e a direção operacional do pessoal nas empresas "Grãos", "Café", "Frango", "Hortifruti" e "Pequena Produção". 
Quadro 18 - Exemplos de atividades administrativas em empresas agropecuárias relacionadas à direção estratégica e operacional da produção.

\begin{tabular}{|c|c|}
\hline $\begin{array}{c}\text { Função } \\
\text { administrativa }\end{array}$ & Exemplos de atividades administrativas \\
\hline $\begin{array}{l}\text { Direção } \\
\text { estratégica da } \\
\text { produção }\end{array}$ & $\begin{array}{l}\Rightarrow \text { Supervisionar as atividades produtivas para o alcance dos objetivos da } \\
\text { empresa. } \\
\Rightarrow \text { Supervisionar o uso dos bens de capital fixo e circulante da empresa. }\end{array}$ \\
\hline $\begin{array}{l}\text { Direção } \\
\text { operacional da } \\
\text { produção }\end{array}$ & $\begin{array}{l}\Rightarrow \text { Comandar e acompanhar o processo produtivo. } \\
\Rightarrow \text { Determinar as tarefas e operações a serem realizadas para o bom andamento } \\
\text { da produção. }\end{array}$ \\
\hline $\begin{array}{l}\text { Direção } \\
\text { estratégica das } \\
\text { finanças }\end{array}$ & $\begin{array}{l}\Rightarrow \text { Definir e supervisionar os usos dos recursos financeiros próprios e de } \\
\text { terceiros na empresa. } \\
\Rightarrow \text { Administrar as finanças da empresa, decidindo sobre gastos ou poupanças e } \\
\text { sobre aplicações ou contratações de recursos financeiros. }\end{array}$ \\
\hline $\begin{array}{l}\text { Direção } \\
\text { operacional das } \\
\text { finanças }\end{array}$ & $\begin{array}{l}\Rightarrow \text { Executar o cronograma financeiro da empresa. } \\
\Rightarrow \text { Gerenciar cotidianamente o fluxo de caixa da empresa. }\end{array}$ \\
\hline $\begin{array}{l}\text { Direção } \\
\text { estratégica da } \\
\text { comercialização }\end{array}$ & $\begin{array}{l}\Rightarrow \text { Executar a estratégia de compra de insumos e venda da produção. } \\
\Rightarrow \text { Estabelecer relacionamentos (comunicação) com clientes e fornecedores de } \\
\text { bens e serviços. }\end{array}$ \\
\hline $\begin{array}{l}\text { Direção } \\
\text { operacional da } \\
\text { comercialização }\end{array}$ & $\begin{array}{l}\Rightarrow \text { Decidir e realizar as compras de insumos e outros fatores de produção. } \\
\Rightarrow \text { Decidir e realizar as vendas da produção. }\end{array}$ \\
\hline $\begin{array}{l}\text { Direção } \\
\text { estratégica do } \\
\text { pessoal }\end{array}$ & $\begin{array}{l}\Rightarrow \text { Promover a seleção, treinamento e desenvolvimento da mão-de-obra. } \\
\Rightarrow \text { Definir formas de comunicação e liderança na empresa. }\end{array}$ \\
\hline $\begin{array}{l}\text { Direção } \\
\text { operacional do } \\
\text { pessoal }\end{array}$ & $\begin{array}{l}\Rightarrow \text { Dar ordens de serviço à mão-de-obra e monitorar o cumprimento das } \\
\text { tarefas. } \\
\Rightarrow \text { Motivar os trabalhadores. }\end{array}$ \\
\hline
\end{tabular}


Quadro 19 - Estimativas sobre o grau de importância (ou relevância) da direção estratégica e operacional para o sucesso das empresas agropecuárias referenciais (escala de 1 a 5)1.

\begin{tabular}{|c|c|c|c|c|c|c|c|}
\hline Atividades administrativas & $\begin{array}{l}\text { EMPRESA } \\
\text { GRÃOS }\end{array}$ & $\begin{array}{c}\text { EMPRESA } \\
\text { BOVINO } \\
\text { DE CORTE }\end{array}$ & \begin{tabular}{ll}
\multicolumn{2}{c|}{ EMPRESA } \\
9 & CANA- \\
& DE- \\
& AÇÚCA \\
& R \\
\end{tabular} & $\begin{array}{c}\text { EMPRESA } \\
\text { CAFÉ }\end{array}$ & $\begin{array}{c}\text { EMPRESA } \\
\text { FRANGO }\end{array}$ & $\begin{array}{c}\text { EMPRESA } \\
\text { HORTIFRUTI }\end{array}$ & $\begin{array}{c}\text { EMPRESA } \\
\text { PEQUENA } \\
\text { PRODUÇÃO }\end{array}$ \\
\hline Direção estratégica da produção & 4 & 4 & 3 & 4 & 3 & 4 & 4 \\
\hline Direção estratégica das finanças & 4 & 3 & 2 & 3 & 2 & 4 & 3 \\
\hline Direção estratégica do pessoal & 3 & 2 & 1 & 3 & 3 & 3 & 3 \\
\hline Direção operacional da produção & 5 & 3 & 3 & 5 & 5 & 5 & 5 \\
\hline Direção operacional das finanças & 5 & 2 & 2 & 3 & 2 & 5 & 2 \\
\hline Direção operacional da comercialização & 5 & 5 & 1 & 4 & 1 & 5 & 3 \\
\hline Direção operacional do pessoal & 4 & 2 & 1 & 5 & 5 & 5 & 5 \\
\hline
\end{tabular}

${ }^{1}$ Os números no interior do Quadro indicam o grau de importância das atividades administrativas, sendo que o número 5 representa um grau muito alto de importância e o número 1 um grau baixo de importância. 


\subsection{O controle nas empresas agropecuárias referenciais.}

Exemplos de atividades administrativas relacionadas ao controle estratégico e operacional das áreas administrativas são mostradas no Quadro 20. O controle abrange as atividades administrativas destinadas a registrar e avaliar o uso de todos os recursos físicos, financeiros, comerciais e humanos da empresa, a fim de mensurar seu desempenho e poder propor as correções necessárias, em tempo oportuno. Daí resulta a classificação adotada nesse trabalho, que abrange: o controle da produção, das finanças, da comercialização e do pessoal.

Normalmente, as ações administrativas voltadas a controlar os recursos da empresa sucedem as ações de planejamento, organização e direção, mas os resultados obtidos com o controle realimentam o processo administrativo, fazendo-o reiniciar, com novos planejamentos, em várias oportunidades. No controle da produção, por exemplo, a coleta, sistematização e avaliação das atividades produtivas podem sugerir a reorientação da produção, com o abandono ou modificação da situação anterior e o início de outro processo produtivo, totalmente diferente ou simplesmente alterado em alguns detalhes.

Considerando a finalidade das atividades de controle e o plano de contas existente na empresa agropecuária, pode-se distinguir vários tipos de controle: o controle de custos, o controle de produção, o controle de estoques, o controle de bens de capital, o controle de contas correntes, o controle de clientes e fornecedores, o controle de pessoal, e o controle de outras informações relevantes para a empresa. No controle de custos destacam-se os registros dos gastos inerentes a cada atividade (centros de custos) da empresa. Nos controles de produção destacam-se os registros de volume e de

produtividade. No caso do controle de estoques destacam-se os registros de uso de insumos inerentes a cada atividade da empresa. No caso do controle de bens de capital destacam-se os registros de uso desses bens em cada atividade da empresa. No caso do 
controle de contas correntes destacam-se os registros que monitoram o caixa, as contas bancárias e o saldo de contas a pagar e a receber. No caso do controle de clientes e fornecedores destacam-se os registros de identificação e do histórico de transações. No caso do controle do pessoal destacam-se os registros de salário, benefícios e encargos sociais e uso da mão-de-obra em cada atividade da empresa. Por fim, vários outros controles podem ser relevantes para a empresa, como dados meteorológicos, histórico de preços de produtos, insumos e indexadores, entre outros.

Nas atividades de controle uma importante distinção deve ser feita. O controle das transações financeiras (fluxo de caixa) e o controle econômico da empresa, que envolve além do fluxo de caixa valores não monetários como, por exemplo, a depreciação e juros sobre o capital fixo no lado dos custos, ou o crescimento e engorda de um animal ou a valorização da terra no lado da renda. 
Quadro 20: Exemplos de atividades administrativas em empresas agropecuárias relacionadas ao controle estratégico e operacional da produção.

\begin{tabular}{|c|c|}
\hline $\begin{array}{c}\text { Função } \\
\text { administrativa }\end{array}$ & Exemplos de atividades administrativas \\
\hline $\begin{array}{l}\text { Controle } \\
\text { estratégico da } \\
\text { produção }\end{array}$ & $\begin{array}{l}\Rightarrow \text { Coletar e sistematizar dados relacionados à produção global da empresa. } \\
\Rightarrow \text { Avaliar a empresa como um todo sob o aspecto produtivo. }\end{array}$ \\
\hline $\begin{array}{l}\text { Controle } \\
\text { operacional da } \\
\text { produção }\end{array}$ & $\begin{array}{l}\Rightarrow \text { Coletar e sistematizar dados relacionados às atividades produtivas da } \\
\text { empresa e ao uso dos capitais fixos e circulantes. } \\
\Rightarrow \text { Avaliar individualmente as atividades da empresa sob o aspecto produtivo e } \\
\text { quanto ao uso dos capitais fixos e circulantes. }\end{array}$ \\
\hline $\begin{array}{l}\text { Controle } \\
\text { estratégico das } \\
\text { finanças }\end{array}$ & $\begin{array}{l}\Rightarrow \text { Coletar e sistematizar dados relacionados às finanças da empresa como um } \\
\text { todo, detalhando as origens (fontes) e aplicações (usos) dos recursos financeiros. } \\
\Rightarrow \text { Avaliar a empresa como um todo nos aspectos econômicos e financeiros. }\end{array}$ \\
\hline $\begin{array}{l}\text { Controle } \\
\text { operacional das } \\
\text { finanças }\end{array}$ & $\begin{array}{l}\Rightarrow \text { Coletar e sistematizar dados econômicos e financeiros das atividades } \\
\text { desenvolvidas pela empresa. } \\
\Rightarrow \text { Avaliar individualmente as atividades da empresa sob os aspectos } \\
\text { econômico e financeiro. }\end{array}$ \\
\hline $\begin{array}{l}\text { Controle } \\
\text { estratégico da } \\
\text { comercialização }\end{array}$ & $\begin{array}{l}\Rightarrow \text { Coletar e sistematizar dados relacionados a comercialização (compras e } \\
\text { vendas) da empresa no médio e longo prazo. } \\
\Rightarrow \text { Avaliar a empresa como um todo no aspecto da comercialização. }\end{array}$ \\
\hline $\begin{array}{l}\text { Controle } \\
\text { operacional da } \\
\text { comercialização }\end{array}$ & $\begin{array}{l}\Rightarrow \text { Coletar e sistematizar dados relacionados a comercialização no ano safra. } \\
\Rightarrow \text { Avaliar individualmente as atividades da empresa sob o aspecto da } \\
\text { comercialização. }\end{array}$ \\
\hline $\begin{array}{l}\text { Controle } \\
\text { estratégico do } \\
\text { pessoal }\end{array}$ & $\begin{array}{l}\Rightarrow \text { Coletar e sistematizar dados relacionados aos recursos humanos da empresa } \\
\text { como um todo. } \\
\Rightarrow \text { Avaliar a empresa como um todo no aspecto dos recursos humanos. }\end{array}$ \\
\hline $\begin{array}{l}\text { Controle } \\
\text { operacional do } \\
\text { pessoal }\end{array}$ & $\begin{array}{l}\Rightarrow \text { Coletar e sistematizar dados relacionados aos recursos humanos nas } \\
\text { atividades da empresa. } \\
\Rightarrow \text { Avaliar as atividades da mão-de-obra na empresa. }\end{array}$ \\
\hline
\end{tabular}




\subsubsection{Relevância do controle}

Tanto em nível estratégico, como em nível operacional merece destaque o grau de importância atribuído ao controle na empresa referencial "Hortifruti", conforme mostram os dados do Quadro 21. A maior importância de se controlar essa empresa deve-se: (a) na área produtiva por possuir inúmeras atividades (produtos hortifrutigranjeiros) com ciclos de produção rápidos e relativamente complexos; (b) na área financeira por operar com elevado montante de capital de giro próprio; (c) na área comercial por possuir grande número de clientes, atuar em diversos canais de comercialização e manter alta freqüência de compras de insumos e vendas da produção; e (d) na área de pessoal por manter elevado número de trabalhadores.

Em outro extremo, merece destaque o baixo grau de importância, atribuído ao controle estratégico e operacional na empresa referencial "Cana-de-açúcar". A menor importância de se controlar essa empresa deve-se: (a) na área produtiva por transferir à indústria a responsabilidade das principais tarefas produtivas e pela menor complexidade de seu processo produtivo; (b) na área financeira por operar com baixo montante de capital de giro próprio; (c) na área comercial por adotar o preço médio como estratégia de comercialização da produção; e (d) na área de pessoal por manter pequeno número de trabalhadores permanentes na empresa.

Nas demais empresas agropecuárias referenciais, normalmente foram atribuídos grau regular ou médio de importância para as atividades administrativas relacionadas ao controle. Vários fatores contribuem para o estabelecimento desse grau mediano de importância do controle nas empresas agropecuárias referenciais: (1) a natureza predominantemente familiar dessas empresas; (2) o baixo grau de diversificação de suas atividades produtivas; (3) a baixa diferenciação de sua produção (centrada em “commodities”); (4) o alto custo para se obter informações detalhadas em 
Quadro 21 - Estimativas sobre o grau de importância (ou relevância) do controle estratégico e operacional para o sucesso das empresas agropecuárias referenciais (escala de 1 a 5) 1.

\begin{tabular}{|l|c|c|c|c|c|c|c|}
\hline \multicolumn{1}{|c|}{ Atividades administrativas } & $\begin{array}{c}\text { EMPRESA } \\
\text { GRÃOS }\end{array}$ & $\begin{array}{c}\text { EMPRESA } \\
\text { BOVINO } \\
\text { DE CORTE }\end{array}$ & $\begin{array}{c}\text { EMPRESA } \\
\mathbf{1 0} \\
\text { CANA- } \\
\text { DE- } \\
\text { AÇÚCA } \\
\mathbf{R}\end{array}$ & $\begin{array}{c}\text { EMPRESA } \\
\text { CAFÉ }\end{array}$ & $\begin{array}{c}\text { EMPRESA } \\
\text { FRANGO }\end{array}$ & $\begin{array}{c}\text { EMPRESA } \\
\text { HORTIFRUTI }\end{array}$ & $\begin{array}{c}\text { EMPRESA } \\
\text { PEQUENA } \\
\text { PRODÇÃO }\end{array}$ \\
\hline Controle estratégico da produção & 3 & 3 & 2 & 3 & 2 & 3 \\
\hline Controle estratégico das finanças & 3 & 3 & 2 & 3 & 2 & 4 & 3 \\
\hline Controle estratégico da comercialização & 2 & 4 & 1 & 3 & 1 & 4 & 2 \\
\hline Controle estratégico do pessoal & 3 & 2 & 1 & 3 & 3 & 3 & 3 \\
\hline Controle operacional da produção & 3 & 2 & 2 & 3 & 3 & 4 & 3 \\
\hline Controle operacional das finanças & 4 & 2 & 2 & 3 & 2 & 5 & 2 \\
\hline Controle operacional da comercialização & 3 & 4 & 2 & 4 & 2 & 4 & 3 \\
\hline Controle operacional do pessoal & 3 & 2 & 2 & 3 & 3 & 3 \\
\hline
\end{tabular}

${ }^{1}$ Os números no interior do Quadro indicam o grau de importância das atividades administrativas, sendo que o número 5 representa um grau muito alto de importância e o número 1 um grau baixo de importância. 
nível de campo; (5) a interferência de fatores não controláveis que trazem incerteza ao processo produtivo; (6) a atitude do produtor em manter-se na atividade mesmo sujeito a momentos adversos; (7) o alto custo para se modificar a estrutura de produção no curto prazo; (8) o baixo nível cultural dos funcionários; (9) a baixa habilidade do produtor em manipular sistemas informatizados; e (10) o maior gosto do produtor rural pelos aspectos produtivos em relação às atividades administrativas, principalmente de controle. Isso não significa que se está recomendando a implantação de poucos controles na empresa agropecuária, mas sim um sistema de controle eficiente que considere os custos e benefícios da informação e que permita analisar a empresa agropecuária e subsidiar o seu processo de decisão.

Não obstante, merece destaque o grau alto de importância atribuído ao controle operacional das finanças na empresa "Grãos", e aos controles estratégico e operacional da comercialização nas empresas "Café" e "Bovino de Corte". Um importante aspecto nas atividades administrativas relacionadas ao controle é que o sistema de controle deve procurar retratar o funcionamento da empresa agropecuária, adaptando-se a ela, e não o contrário, como às vezes ocorre quando se tenta implantar "pacotes fechados" de controle nas empresas agropecuárias. 


\section{CONCLUSÕES}

O presente trabalho analisou o processo administrativo da empresa agropecuária e identificou as principais razões que levam a uma baixa adoção de técnicas de gestão nessas empresas. A hipótese de que um conjunto de razões, vinculadas ao conhecimento, habilidades e atitudes de técnicos e produtores, é que limita a adoção de técnicas de gestão nessas empresas foi testada e confirmada pelo estudo. $\mathrm{O}$ referido conjunto de razões foi inicialmente tratado de forma qualitativa, através de reuniões de grupos focais com agricultores e pecuaristas e com profissionais que prestam assistência técnica à agricultura e pecuária. Em seguida, o assunto foi abordado de forma quantitativa, através de aplicação de questionário estruturado junto ao mesmo público alvo. Visando um maior detalhamento do assunto e sua discussão em acordo com a teoria da administração, o processo administrativo da empresa agropecuária foi subdividido e apresentado em uma matriz de atividades administrativas, que permitiu relacionar as funções de planejamento, organização, direção e controle, com as áreas administrativas de produção, finanças, comercialização e pessoal.

Em vista das contribuições apresentadas ao longo do texto as seguintes conclusões gerais podem ser enumeradas: (1) a natureza familiar predominante na empresa agropecuária lhe confere uma forma própria de gestão, que muitas vezes contraria o objetivo da maximização de lucros estabelecido pela teoria neoclássica; (2) há importantes e significativas diferenças na opinião e percepção de técnicos e produtores sobre a melhor forma de gerenciar as empresas agropecuárias; (3) a baixa participação dos técnicos no processo administrativo da empresa agropecuária se deve muito mais a atitudes negativas dos produtores rurais, do que a atitudes negativas dos 
técnicos, sobre o problema. Os produtores, ao contrário dos técnicos, entendem que esses profissionais devem priorizar as questões tecnológicas, em sua prestação de serviço às propriedades rurais; (d) atualmente, tanto os produtores, como os técnicos reconhecem a necessidade da empresa agropecuária de adotar um critério mais formal de planejamento, uma organização mais eficiente das áreas administrativas, uma direção mais abrangente da empresa e um controle mais pormenorizado das atividades desenvolvidas. Isso sugere que, no futuro, seja ampliada a demanda por serviços de assessoria administrativa às empresas agropecuárias no Brasil, em complemento a atual forma tradicional de atuação da assistência técnica, e finalmente, (e) as recomendações para as formas de gerenciamento da empresa agropecuária devem considerar as características da empresa e do empresário rural, e não serem estabelecidas a priori sem o conhecimento da situação particular de cada caso.

Com relação às limitações que dificultam o planejamento da empresa agropecuária pode-se concluir: (a) os produtores rurais não alteram, contínua e sistematicamente, seu planejamento estratégico de produção, em função das incertezas de mercado e dos custos associados à alteração do processo produtivo. Portanto, as simulações utilizadas no planejamento da produção devem considerar essa característica da empresa agropecuária, e não simplesmente propor alterações sem avaliar os custos econômicos e de aprendizagem inerentes às mudanças; e (b) no planejamento financeiro, os produtores rurais normalmente direcionam seus recursos para serem aplicados em estoques ou ativos fixos, pois preferem trabalhar suas atividades com maior estoque de capital do que com maior liquidez em caixa. Desta forma, nas recomendações sobre o planejamento financeiro deve-se indicar as vantagens e desvantagens dessa prática no resultado econômico da empresa agropecuária;

Com relação às limitações que dificultam a organização da empresa agropecuária pode-se concluir: (a) na organização da infraestrutura e do pessoal na empresa agropecuária, há uma tendência dos produtores em superdimensionar a disponibilidade desses fatores de produção, visando uma redução dos riscos operacionais 
inerentes a produção. Portanto, nas recomendações sobre a organização física e de pessoal devem ser considerados os ganhos e perdas dessa prática no resultado econômico da empresa; e (b) na organização das finanças na empresa agropecuária, normalmente há um descompasso entre o detalhamento dos registros idealizados por técnicos ou empresas de informática e a real capacidade dos produtores rurais de implementá-los com eficiência na empresa. Assim, há que se considerar nas recomendações administrativas a relação benefício/custo do sistema de informação a ser implantado na empresa agropecuária.

Com relação às limitações que dificultam a direção na empresa agropecuária pode-se concluir: (a) a estrutura funcional dos recursos humanos é centralizada, com acúmulo de responsabilidades no produtor rural, gerando ineficiências decorrentes da baixa delegação de atribuições ao restante da mão-de-obra. Portanto, há que se questionar essa estrutura funcional predominante nas empresas agropecuárias e estabelecer políticas para uma melhor capacitação do recurso humano nessas empresas; e (b) a direção operacional da produção ocupa o maior tempo de trabalho do produtor rural e normalmente direciona-se à busca por maiores produtividades. Nessa situação é preciso avaliar melhor o processo de perseguir maiores produtividades físicas a qualquer preço, procurando adicionar ganhos por uma melhor direção das finanças, da comercialização e do recurso humano.

Com relação às limitações que dificultam o controle na empresa agropecuária pode-se concluir: (a) as principais dificuldades no controle da empresa agropecuária são a coleta de dados a campo, proporcionada pelo baixo nível de conhecimento, habilidades e atitudes de seus funcionários em relação às tarefas de controle. Portanto, há que se desenvolver sistemas mais simples e versáteis de controle no âmbito da empresa agropecuária e que considerem a limitação cultural de seus funcionários; e (b) há, por um lado, uma atitude favorável de produtores e técnicos em se aperfeiçoar o sistema de controle da empresa agropecuária, mas, por outro, um reconhecimento dos produtores sobre as dificuldades de implantá-los e utilizá-los 
gerencialmente. Dessa forma, há que se desenvolver futuras pesquisas orientadas para o estudo específico de determinados sistemas de produção e para o estabelecimento de rotinas de trabalho em gestão para os profissionais da assistência técnica. 


\section{REFERÊNCIAS BIBLIOGRÁFICAS}

AHN, C.; SINGH, I.; SQUIRE, L. A model of an agricultural household in a multicrop economy. The case of Korea. Review of Economics and Statistics, v.1. n.63, p.520-25, 1980.

AMBRÓSIO, L.A. Planejamento do uso sustentável da terra em microbacias hidrográficas: uma abordagem de programação por metas. Piracicaba, 1997. 145p. Tese (Doutorado) - Escola Superior de Agricultura "Luiz de Queiroz", Universidade de São Paulo.

ASSOCIAÇÃO BRASILEIRA DE MARKETING RURAL. Perfil do consumidor de insumos agropecuários, 1991/92 - 1998/99. São Paulo, 2000. 21p.

ATTONATY, J.M.; CHATELIN, M.H.; GARCIA, F. Interactive simulation modeling in farm decision-making. Computers and Eletronics in Agriculture, v.22, p.157170, 1999.

BADER, G.E.; ROSSI, C.A. Focus groups: a step-by-step guide. s.l.: The Bader Group, 1999. 39p.

BARNUM, H.; SQUIRE, L. An econometric application of the theory of the farmhousehold. Journal of Development Economics, v.1, n.6, p.79-102, 1979. 
BURKE, T.J.; MOLINA FILHO, J. Fundamentos teóricos e instrumentos para a assistência técnica à agricultura. Piracicaba: ESALQ, 1979. 88p. (Série Didática, 43).

CARLINI-COTRIM, B. Potencialidades da técnica qualitativa grupo focal em investigações sobre abuso de substâncias. Revista Saúde Pública, v.30, n.3, 285293, 1996.

CHIAVENATO, I. Teoria geral da administração: abordagens prescritivas e normativas da administração. 4.ed. São Paulo, McGraw-Hill; Makron Books, 1993. $2 \mathrm{v}$.

CHIESA, A.M.; CIAMPONE, M.H.T. Princípios gerais para a abordagem de variáveis qualitativas e o emprego da metodologia de grupos focais. s.n.t. (Mimeografado).

DALMAZO, N.L.; ALBERTONI, L.A. A necessidade de um enfoque de administração rural na pesquisa e extensão rural. In: SEMANA DE ATUALIZAÇÃO EM ADMINISTRAÇÃO RURAL, Lages, 1991. Anais. Florianópolis: SAA; EPAGRI; CTA do Planalto Serrano Catarinense, 1992. p.7-21.

GERALDO, L.G. Avaliação do programa de administração rural da Emater-MG: atitudes de técnicos e a eficiência gerencial de produtores rurais. Lavras, 1991. 95p. Dissertação (MS) - Escola Superior de Agricultura de Lavras.

GRAY, D.; KEMP, E.; GARDNER, J. The problem solving processes used by farm management consultants. In: INTERNATIONAL FARM MANAGEMENT CONGRESS, 12., Durban, 1999. Proceedings. Earley Gate: International Farm Management Association, 1999. p.659-670. 
GUADAGNIN, D. Comunicação interpessoal e a administração rural. Um estudo no Estado de Santa Catarina. Lavras, 1995. 129p. Dissertação (MS) - Universidade Federal de Lavras.

HOFFMANN, R.; ENGLER, J.J.C.; SERRANO, O. Administração da empresa agrícola. 7.ed. São Paulo: Pioneira, 1992. 325p.

JESUS, J.C.S. Trajetória de decisões administrativas na unidade camponesa e na empresa agropecuária capitalista: Estudo de casos no Sul de Minas Gerais. Lavras, 1993. 147p. Dissertação (MS) - Escola Superior de Agricultura de Lavras.

LANGEMEIER, M.R.; DELANO, F.D. Characteristics of highly efficient farms. In: WESTERN AGRICULTURAL ECONOMICS ASSOCIATION ANNUAL MEETING, Fargo, 1999.

LIMA, A.P.; BASSO, N; NEUMANN, P.S. et al. Administração da unidade de produção familiar: modalidades de trabalho com agricultores. Ijuí: UNIJUÍ, 1995. $175 p$.

LOPES, R.S. A extensão rural e a assistência técnica no Brasil: um compromisso com o futuro. Brasília: Embrater, 1989. 32 p.

McLEOD, J.M.; CHAFFEE, S.H. Interpersonal aproaches to communication research. American Behavioral Scientist, v.16, n.14, p.469-499, 1973.

MEIRA, J.L. Sucesso econômico e perfil estrategista empreendedor de produtores rurais: o caso Nilo Coelho. Lavras, 1996. 76p. Dissertação (MS) - Universidade Federal de Lavras. 
MIller, A.; BOEHLJE, M.; DOBBINS, C. Positioning the farm business. West Lafayette: Purdue University, 1998. 37p. (Staff Paper, 98-9).

NORONHA, J.F. Projetos agropecuários. 2.ed. São Paulo, Atlas, 1987. 269p.

NORONHA, J. F.; PERES, F. C. Rumos futuros da administração rural. In: SEMANA DE ATUALIZAÇÃO EM ADMINISTRAÇÃO RURAL, Lages, 1991. Anais. Florianópolis: SAA; EPAGRI; CTA do Planalto Serrano Catarinense, 1992. p.251260.

OLINGER, G. Como melhorar a eficácia da extensão rural no Brasil e na América Latina. Brasília: EMBRATER, 1984. 52p. (Série Leituras Selecionadas, 13).

OLINGER, G. Extensão rural: verdades e novidades. Florianópolis: EPAGRI, 1998. $113 p$.

OLIVEIRA, D.P.R. de. Planejamento estratégico: conceitos, metodologias e práticas. 14.ed. São Paulo: Atlas, 1999. 303p.

PHILLIPS, J.C.; PETERSON, H.C. Strategic planning and firm performance: a proposed theorical model for small agribusiness firms. East Lansing: Michigan State University, 1999. 15p. (Staff Paper, 99-41).

PRIMDAHL, J. Agricultural landscapes as places of production and for living in owner's versus producer's decision making and the implications for planning. Landscape and Urban Planning, v.1, n.46, p.143-150, 1999.

ROCKENBACK, I. H. A mulher na administração da empresa familiar rural: o caso de um grupo de gestão agrícola em Santa Catarina. Lavras, 1995. 80p. Dissertação (MS) - Universidade Federal de Lavras. 
ROUGOOR, C.W.; TRIP, G.; HUIRNE, R.B.M. et al. How to define and study farmers' management capacity: theory and use in agricultural economics. Agricultural Economics, v.3, n.18, p. 261-272, 1998.

SAXOWSKY, D.M.; DUNCAN, M.R. Understanding agriculture's transition into the $21^{\text {st }}$ century: challenges, opportunities, consequences and alternatives. Fargo: North Dakota State University, 1998. 32p. (Agricultural Economics Miscellaneous, 181)

SCITOVSKY, T. Welfare and competition: the economics of a fully employed economy. Chicago: Richard D. Irwin, 1951.

SINGH, I.; SQUIRE, L.; STRAUSS, J. An overview of agricultural household models the basic model: theory, empirical results and policy conclusions. In: SINGH, I.; SQUIRE, L.; STRAUSS, J. Agricultural household models, extensions, applications and policy. Washington: The World Bank; The Johns Hopkins University Press, 1986, p.17-91.

SOUZA, R. de; GUIMARÃES, J.M.P.; MORAIS, V.A. et al. Administração da fazenda. 3.ed. São Paulo: Globo, 1990. 211p.

SUMPSI, J.M.; AMADOR, F.; ROMERO, C. On farmers' objectives: a multi-criteria approach. European Journal of Operational Research, v.1, n.96, p.64-71, 1997.

VALE, S.M.L.R. Avaliação de sistemas de informação para produtores rurais: metodologias e um estudo de caso. Viçosa, 1995. 139p. Tese (Doutorado) Universidade Federal de Viçosa. 
WESTHUIZEN, C.; VILJOEN, M.F. The relationship between the performance of farmers and their biography and management practices. In: INTERNATIONAL FARM MANAGEMENT CONGRESS, 12., Durban, 1999. Proceedings. Earley Gate: International Farm Management Association, 1999. p.869-881.

WESTPHAL, M.F. Grupos focais: experiências precursoras em programas educativos em saúde no Brasil. Boletim Oficina Sanitária Panamericana, v.120, n.6, p.472482, 1996.

WOODBURN, M.R Computer use and factors influencing computer adoption among commercial farmers in Natal Province, South Africa. Computers and Eletronics in Agriculture, v.11, n.2/3, 1994.

WYLIE, P. Profit, management and sustainable agriculture. In: INTERNATIONAL FARM MANAGEMENT CONGRESS, 12., Durban, 1999. Proceedings. Earley Gate: International Farm Management Association, 1999. p.589-597. 


\section{A P E N D I C E S}




\section{APÊNDICE 01: Síntese dos depoimentos ${ }^{55}$ nos grupos focais.}

Na sequiência de sua realização, transcreve-se pela ordem os depoimentos dos técnicos e produtores rurais das quatro primeiras sessões de grupos focais: (a) grupo focal com técnicos para a agricultura da região de Campo Mourão/Pr; (b) grupo focal com agricultores da região de Campo Mourão/Pr; (c) grupo focal com técnicos para a agricultura da região de Castro/Pr; (d) grupo focal com agricultores da região de Castro/Pr.

Neste ponto, vale ressaltar, que cada frase se refere a uma opinião exposta pelo participante. Um bloco de frases representa um conjunto de opiniões exposto por um participante em determinado momento do debate. Com o objetivo de se separar o depoimento de cada participante (mudança de interlocutor) utilizou-se de espaços duplos (linhas em branco) entre um bloco de sentenças.

\section{(a) GRUPO FOCAL COM TÉCNICOS - CAMPO MOURÃO - 01/06/00.}

Explicações iniciais ....

Auto apresentação dos participantes ...

Os produtores usam muito pouco as técnicas de gestão, principalmente, por falta de orientação da assistência técnica. Os agrônomos estão mal preparados.

Primeiro é preciso melhorar a tecnologia, depois se preocupar com gestão.

Os agrônomos precisam buscar aperfeiçoamento.

O produtor entende, inicialmente, que a educação formal não é necessária. Por falta de formação ele não demanda serviços de gestão. O planejamento é importante para o

\footnotetext{
${ }^{55}$ Os depoimentos apresentados nesse apêndice não se referem, necessariamente, a transcrição literal das palavras ou expressões utilizadas pelos técnicos e produtores rurais. Na maioria dos casos, procurou-se relatar o significado dos depoimentos, porém sem preocupação com o rigor ortográfico (muitas gírias ou expressões idiomáticas foram mantidas).
} 
produtor saber onde quer chegar, mas o produtor não planeja por problema cultural. Ele é empírico.

Realmente o produtor não planeja por problema cultural e de falta de estudo. $\mathrm{O}$ agrônomo também só pensa em tecnologia e esquece da parte administrativa. $\mathrm{O}$ produtor, na maior parte das vezes, enxerga apenas a parte física (por exemplo, a falta de máquinas). Além disso, muda constantemente seus planos. $\mathrm{O}$ produtor planeja no máximo para um ano. O produtor é imediatista.

Mudança macroeconômica (antes e depois do Real): a administração do produtor era empírica e dava certo antes do Real. Apesar da inflação ele raciocinava em produto (o que era correto). O negócio ia bem. Hoje o produtor reconhece que precisa de planejamento. Os agrônomos são mal formados. Já fiz uma tentativa de introduzir uma administração mais formal em propriedades rurais, mas rapidamente a coisa morreu.

Após o Plano Real quem entrou em banco para fazer investimento quebrou. Não há nenhuma administração do RH (recursos humanos). O produtor pode até ser austero com relação a gastos, mas a família não o é. Se o agrônomo tocar nessa ferida (gastos familiares) você perde o seu cliente (produtor rural).

O produtor não dá acesso ao técnico a informações sobre a parte financeira (mesmo se esse for o problema mais importante da propriedade). Só permite acesso às questões tecnológicas. O produtor não aceita baixar de nível socioeconômico. A geração atual não vai mudar seu comportamento, principalmente porque ele tinha sucesso no passado.

Cerca de $45 \%$ dos produtores brasileiros tem mais de 55 anos de idade e o tempo médio de escolaridade não chega a 4 anos. 
Atualmente, o comando do negócio está em mãos de pessoas mais velhas. Acumulou-se capital no passado. O agrônomo não desperta ou incentiva o produtor para trabalhar com gestão.

Todos os presentes sabem operar um computador.

Nos últimos 10 anos a tecnologia foi que aumentou a produção. A tecnologia é um fator de expurgo. Quem não adota sai fora. O pai de família (hoje mais democrático) não consegue segurar os gastos familiares. No passado quem não reinvestia (em terras ou máquinas) totalmente seu capital de giro era considerado burro. De tanto insistência o produtor passou a comprar máquinas, terra, etc. e se endividou. Após o término da inflação não conseguiu mais pagar. No passado a gestão não ia resolver o problema. Ao contrário, poderia até atrapalhar o produtor.

Quem não investiu permanentemente em tecnologia já saiu do mercado. A mudança do produtor para a cidade elevou os gastos familiares (na cidade) e os gastos na propriedade (maior contratação de mão de obra). Esse fato passou despercebido para muitos produtores, mas se ele tivesse gestão ele teria enxergado antes o problema. Outra questão é o tamanho da propriedade, que hoje não suporta mais os gastos da família. A relação de troca é hoje mais desfavorável. A idade do produtor dificulta mudanças (ele não foi educado para isso). Os filhos têm vindo com nova mentalidade.

Os filhos talvez vão melhorar a gestão. Planos de rotação, por exemplo, não são seguidos porque o produtor é imediatista (o preço de mercado faz ele mudar/alterar o sistema de rotação).

A visão do caixa e a visão do RH são bem mais desenvolvidas quando as pessoas têm experiência fora da agricultura (comércio).

A questão cultural é a mais relevante. O produtor não permite o acesso do técnico as contas pessoais ou da família, que estão misturadas com a conta da propriedade. 
A tecnologia e a escala contribuíram para a saída de alguns produtores que foram incorporados por outros.

No passado a maior lucratividade da agricultura tornava quase impossível a introdução de sistemas de controle.

O produtor, porém, quer hoje mais informação. Até porque hoje a rentabilidade é menor.

Hoje, o agrônomo está muito distante do agricultor. Antes a relação era mais próxima (fraternal). Almoçava-se, com freqüência, na casa do agricultor. O produtor só vai confiar em você, se você conhecer a família dele, o jeitão dele. Só assim você tem acesso ao que se passa na cabeça dele, aos planos dele (às vezes dito pela mulher do produtor durante um almoço). Hoje a relação entre produtor e agrônomo é puramente comercial. Não há mais aquela aproximação como antes. Se você não conhece o produtor, nada você pode fazer em gestão. A confiança que o agricultor tem em você é fundamental.

Há grande resistência da maioria dos produtores em anotar, por exemplo, as horas de uso dos tratores na propriedade. Se você insiste e o produtor não faz, você acaba se desmotivando também. Alguns poucos da geração mais nova de produtores, porém, parecem ter uma nova mentalidade. A assistência integral é muito cara. Os produtores mais velhos não têm conhecimento de gestão e o técnico não faz a gestão por ele, porque o modelo atual da assistência técnica não permite por questão de tempo e pelo custo para se trabalhar com gestão.

O produtor rural tem um gosto maior pelos aspectos da produção (questão cultural). Com a nova geração, principalmente quando vem de outros setores, é mais fácil. Além disso, o produtor precisa do efeito demonstração para se sensibilizar e fazer a adoção das práticas de gestão. Falta tempo para o técnico criar esse efeito demonstração.

Nas questões tecnológicas criar o efeito demonstração é mais fácil. É difícil mostrar que a gestão vai aumentar, por exemplo, a produção de soja do produtor. 
A adoção de tecnologia é um fator indispensável (pois ela exclui os produtores que não adotam). Ela, porém, não garante aumento de lucro. Ela apenas exclui quem não adota e mantém na atividade quem adota.

É importante que o produtor não perca a liderança junto à família. Ele hoje não manda tanto quanto mandava no passado.

É preciso conter os gastos familiares, que hoje exigem mais do que a propriedade rende. Dos médios e grandes produtores apenas $16 \%$ ganham dinheiro. Dos pequenos e mini 8 \% ganham dinheiro. A renda líquida do restante é negativa. Há uma clara tendência de continuar a redução do número de produtores.

Tecnologia sem relação econômica custo variável/benefício não é nada. O cálculo do custo é importante. A principal dificuldade é a coleta de dados. A assistência técnica não está preparada para esse trabalho. O uso de software é difícil e as versões, desses programas, mudam muito rápido. Falta tempo para os técnicos devido o modelo atual de assistência.

Para o produtor não é a dificuldade o fator principal. O fator principal é a falta de interesse.

O produtor demanda apenas tecnologia. Não demanda técnicas de gestão.

Para o agrônomo a dificuldade de aprender técnicas de gestão não é grande. $\mathrm{O}$ agrônomo, no entanto, tem que seguir a política da empresa onde trabalha e, as empresas seguem um modelo de assistência que não dão tempo ao técnico para trabalhar com gestão.

Os grandes produtores podem receber apoio em gestão. Mas quais agrônomos vão dar assistência aos pequenos?

O acompanhamento de gestão é diário. O produtor é que tem que fazer. O técnico não tem tempo para isso. 
Os produtores estão muito mal acostumados. Acham que o técnico tem que fazer tudo para eles.

O produtor e a assistência técnica só pensam em aumentar a produtividade. Ninguém pára (nem produtores, nem técnicos) para pensar e identificar onde estão as gorduras e fazer contas. Entre agrônomos só se conversa sobre produtividade. Não se fala sobre custos, sobre a adequação de máquinas, etc.

Custo/beneficio é importante.

O produtor confiar no técnico é fundamental.

Quem trabalha com vários produtores tem que fazer gestão em uma propriedade para ter o efeito demonstração.

Obviamente existem exceções, pois existem produtores que já trabalham com computador na fazenda (o administrador foi treinado e é ele quem digita os dados).

Os agrônomos não estão preparados para fazer gestão. Só não ficam em má situação porque os produtores não cobram esse serviço.

O agrônomo não conhece o produtor. Não sabe como ele administra a propriedade. Não sabe sobre sua situação financeira. É difícil fazer recomendações administrativas.

O médico, por exemplo, procura saber quase tudo antes de dar o seu diagnóstico e recomendar um tratamento.

Os agrônomos e produtores são ambos conservadores, por isso é que se dão bem.

Os agrônomos não sabem "vender" serviços de gestão. Isso é um processo educativo que leva tempo.

A gestão não aumenta a produtividade. Mas ajuda saber sobre os gargalos.

Muitos administradores de fazenda ganham mais que agrônomos. O produtor sabe ajudar quem ajuda ele.

A demanda de dinheiro pela família é grande. 
O produtor precisa para custear a família pelo menos 2 a 2,5 mil por mês. Isso significa uma grande área de lavouras.

Nós, agrônomos, seremos mais exigidos pela geração dos filhos dos agricultores.

A tecnologia expurga. Ela é necessária para se manter na atividade, não para ganhar mais.

O produtor precisa se transformar em um empresário rural (comercializar bem, etc.).

Se a agricultura muda, a assistência técnica deve mudar.

Ela precisa fazer o planejamento estratégico da fazenda. O acompanhamento e a organização devem ficar por conta do produtor.

Não basta só aumentar a produtividade. É necessário, também, racionalizar os gastos.

Nós fazemos assistência tecnológica e somos "despachantes" na área do planejamento e de crédito.

Precisamos nos envolver com planejamento e comercialização.

Nós somos engenheiros e precisamos engenhar. Regular plantadeira ou pulverizador não é serviço de engenheiro.

\section{(b) GRUPO FOCAL COM AGRICULTORES - CAMPO MOURÃO - 01/06/00.}

Explicações iniciais ...

Falta ensino e treinamento.

O produtor mistura o caixa da propriedade com o caixa da família. Isso dificulta a visualização de resultados. 
Falta assessoramento em comercialização.

O produtor não sente necessidade de um controle rigoroso.

Se você controlar entrada e saída basta. O meio pode ficar solto, pois o produtor está cotidianamente na propriedade. É melhor ele ser ativo na propriedade do que perder tempo com controles rigorosos.

O maior problema é misturar propriedade com família. Quando começa melhorar a renda da propriedade, a família gasta mais.

Outros problemas são a comercialização e o baixo nível cultural dos trabalhadores.

Eu sei que a separação do caixa e o treinamento do pessoal são importantes. Eu não faço porque sinto dificuldade em fazer.

O planejamento é a raiz de tudo para se saber onde se quer chegar.

O controle é difícil de fazer e precisa de uma retaguarda (pessoal treinado) na propriedade.

Para os produtores grandes tudo é viável. Os pequenos devem se associar (na área de máquinas, etc.).

Dividir a propriedade é suicídio.

É difícil separar o caixa da propriedade e o da família.

O negócio é reduzir custos e tirar o máximo proveito nas vendas.

Sociedades com irmãos, cunhados, etc. torna incontrolável a retirada de caixa da propriedade.

É difícil medir o resultado, pois a agricultura é uma seqüência de cultivos e você não pode analisar as coisas individualmente. Isso desmotiva o controle.

Os resultados do processo de controle demoram muito para aparecer.

O rateio dos custos fixos é difícil de fazer. 
A mão de obra é o principal fator limitante para o controle e outras coisas.

Acho que o meu planejamento e controle empíricos são razoáveis.

A agricultura precisa de profissionalismo (planejamento, controle e separação do caixa família/propriedade).

O importante é planejar o fluxo de caixa.

O problema do baixo controle é cultural.

Os agrônomos não têm conhecimento na área administrativa.

Se o produtor formador de opinião fizer gestão, o negócio aos pouco pega.

O controle na propriedade pequena não é muito necessário.

O nível dos funcionários é o fator limitante.

O avanço tecnológico das máquinas (colheitadeiras) é muito rápido e o desenvolvimento da mão de obra é lento.

O produtor sabe em quantidade de produto qual é o custo dele (em sacas por alqueire). Não em detalhes, mas sabe.

O produtor não tem tempo para fazer planejamento. É uma correria todo dia.

Outra dificuldade é a falta de um padrão de análise. Por exemplo, alguns consideram a seqüência de cultivos. Outros rateiam o custo fixo em $2 / 3$ para o verão e $1 / 3$ para o inverno, etc. Não há uma padronização. Se tiver programa de rotação dificulta ainda mais.

Na empresa urbana há um padrão de contabilidade. No meio rural não.

A análise final é muito demorada e complicada.

A rotação de culturas dificulta a análise. 
A contabilidade rural é voluntária, por isso ela é bagunçada.

O agricultor de forma alguma permite que o técnico tenha acesso aos dispêndios pessoais ou familiares.

Os agricultores não aceitam críticas pessoais (principalmente os de maior idade e com menor nível cultural).

Os agricultores não aceitam erros do agrônomo e, como a maioria dos técnicos não está bem preparado na parte administrativa, evita-se discutir esse assunto.

Outro problema é o custo mais elevado da assistência mais abrangente.

Não dá lucro para as empresas ajudar o produtor na administração de sua propriedade. $\mathrm{O}$ que dá lucro é vender insumos, etc.

Os agrônomos querem vender o produto da empresa onde trabalham.

Sem maior educação formal o produtor não vai demandar dos técnicos serviços de gestão.

O processo de desenvolvimento da administração rural está apenas iniciando. Esse processo exige um longo prazo para a sua consolidação.

Às vezes a recomendação técnica não tem viabilidade econômica.

A administração é coisa que o próprio produtor deve fazer. Não é uma atividade possível de ser repassada a outras pessoas.

O controle é importante, mas o produtor deve continuar sempre tentando aumentar a produtividade. Apenas deve ser racional. 
O que os vizinhos fazem e o que está na moda motiva o agricultor no processo de adoção.

\section{(c) GRUPO FOCAL COM TÉCNICOS - CASTRO - 09/06/00.}

Explicações iniciais ...

Falta preparação do elemento humano para uma gestão mais elaborada, principalmente com relação à análise dos dados.

Na região existe 2 ou 3 produtores com alto nível de gerenciamento. Com pessoas específicas na propriedade para tratar desse assunto.

A maioria dos agrônomos atende em média 25 produtores que somam uma área de aproximadamente 6 mil hectares. Não há condições de assessorar produtores na parte administrativa. Só o tempo gasto em deslocamento já é grande.

O conhecimento do técnico também é baixo nessa área administrativa.

Nosso trabalho se restringe a acompanhar o desenvolvimento da cultura do plantio a colheita.

Quando o gerenciamento é terceirizado pelo produtor, ele é entregue a profissionais/empresas especializadas ou pessoas especificas na propriedade.

O agrônomo não se envolve.

O gerenciamento é necessário.

No passado a inflação encobria as ineficiências. As margens da agricultura também eram maiores. O gerenciamento era pouco usado.

O modelo atual de assistência não dá tempo aos técnicos para atuarem na área administrativa.

A gestão deve ser feita por pessoas especializadas no assunto (gerentes contratados). 
O agrônomo deve fazer apenas o planejamento agrícola. O trabalho do agrônomo é muito especializado (por ex. grandes culturas).

Há confiança entre produtor e agrônomo quando se fala em agronomia. $\mathrm{Na}$ área de gestão os produtores nos pedem apenas algumas "dicas", como por exemplo, para compra de máquinas, etc.

O modelo de assistência técnica predominante é de atendimentos eventuais.

A assistência para grupos já é um avanço, mas ainda assim fica restrito à área tecnológica.

Os pequenos produtores se envolvem com trabalhos operacionais manuais e, assim, não tem tempo para a parte administrativa.

Quando anotam não sabem analisar os dados.

O agrônomo é deficiente na área de gestão e forte na área técnica.

Apenas há pouco mais de 10 anos começou-se a se falar em gerenciamento rural. Seu desenvolvimento é questão de tempo, mas há necessidade de treinamento.

Os produtores são eficientes em produção (a despeito das dificuldades do setor) e no gerenciamento de máquinas, empregados, etc... Sua principal dificuldade é o gerenciamento financeiro. O crédito farto no passado ajudou a formar uma dívida grande.

Softwares rurais existem. O gargalo é coletar dados, devido a predominância de funcionários desqualificados.

A queda de margens dificulta o pagamento de dívidas antigas.

Os preços de commodities (grandes culturas) são ditados pelo mercado exigindo do produtor pouca habilidade em comercialização. 
O pós-porteira pode ser trabalhado por associações ou cooperativas. Na compra de insumos mais baratos, etc...

Para o produtor o mais importante é ele ser bom tecnicamente.

O agrônomo participa na sugestão de diversificação de culturas ou de outras alternativas de produção via esboço de projetos.

O currículo de agronomia é muito vasto. A fitotecnia é privilegiada. A área de gestão é deficiente.

As escolas formam mais um extensionista do que um consultor.

O modelo de assistência é que determina o pouco envolvimento dos técnicos em gestão. E o produtor também não dá abertura. E também não demanda serviços de gestão.

O currículo de agronomia é muito amplo e pouco profundo mesmo na área técnica.

Para pequenos produtores não vale a pena entrar em detalhes de gestão. Se fizer muitas contas aparece o prejuízo. O jeito é ir levando. Considerar apenas o custo variável e ficar com o que sobra.

Em grãos a área mínima é de 300 hectares, gerando uma renda líquida de $\mathrm{R} \$ 60.000$ por ano ou R 5.000 por mês. A divisão da terra por sucessão é um problema sério.

O nível educacional é muito importante para a adoção de técnicas de gestão.

O gerenciamento quando usado traz resultado econômico, principalmente para os grandes produtores.

A política agrícola no passado protegia o produtor.

Hoje as margens são menores. A crise é pior para os pequenos produtores.

$\mathrm{Ou}$ as pequenas propriedades se especializam em produtos de alto valor agregado ou desaparecem. 
Para pequenos produtores programas comuns de gerenciamento trazem bons resultados (Ex. Programa Latão Cheio). Apenas corrigindo fundamentos básicos. Esses programas devem ter o apoio de empresas ou governos.

A direção muita vezes autoritária dos produtores se valem de filhos (muitas vezes formados em terceiro grau) para serem apenas um peão na fazenda (motorista, realizador de pagamentos, etc.).

A dificuldade vai mudar esse tipo de comportamento.

Simples planilhas eletrônicas para calcular custos de produção já ajudariam muito. Com dados estimados, pois a coleta de dados (de máquinas, por exemplo) é muito difícil. A anotação dos funcionários é péssima (falta qualificação).

Em função do custo o produtor tem dificuldade para contratar profissionais em tempo integral.

\section{(d) GRUPO FOCAL COM AGRICULTORES - CASTRO ${ }^{56}$ - 09/06/00.}

$\mathrm{Na}$ agricultura, a época para a realização de despesas é bem definida. Como os preços variam muito, necessita-se ter um alto volume de capital de giro na atividade agrícola, para evitar vendas em momentos ruins.

O juro alto e o crédito escasso dificultam a administração do fluxo de caixa.

Não há nos mercados locais profissionais especializados em comercialização.

A instabilidade de preços dificulta a comercialização e a análise de investimento.

A economia de escala na produção é muito importante (principalmente o dimensionamento do maquinário).

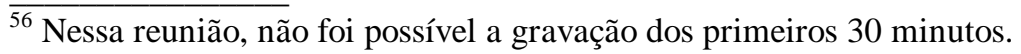


O escalonamento da produção, possível no Brasil ao contrário de Europa e Estados Unidos, com variedades de ciclo curto e longo minimiza esse problema com o maquinário.

Nas economias desenvolvidas o agricultor é protegido.

Nossos maiores problemas são as variações de mercado e o governo.

O técnico não consegue ser bom em tudo (produção e comercialização).

Se ele for um bom agrônomo em tecnologia já está bom demais. Ele deve ser especialista. Da mesma forma o financeiro deve ser um especialista.

Dentro da porteira o produtor é eficiente. Depois de obter a produção máxima, tenta-se vender da melhor maneira possível.

A parte financeira é a mais difícil.

O super investimento em máquinas é compensado por menores perdas de colheita e pela possibilidade de um plantio em dias mais apropriados.

As compras de insumos e as vendas da produção devem ser feitas através da cooperativa. Aqui não existe preço de balcão. Forma-se lotes e busca-se o melhor preço.

Nosso maior problema é da porteira para fora. Inclusive as questões burocráticas (exigências de documentos).

A parte comercial deve caber ao produtor.

O agrônomo deve se envolver mais com outras atividades.

Discordo, o agrônomo deve ser especialista em tecnologia.

A missão do produtor é produzir. Sempre... Apesar de todas as dificuldades.

$\mathrm{Na}$ Europa, mesmo em épocas de guerras, o produtor continuava lavrando e cultivando suas terras. 


\section{APÊNDICE 2: Questionário}

\section{QUESTIONÁRIO SOBRE ADMINISTRAÇÃO RURAL}

* Pedimos sua colaboração para responder esse questionário.

* O questionário faz parte de um projeto de tese de doutorado desenvolvido por pesquisador da Universidade Federal do Paraná.

* Através dele, pretende-se conhecer melhor a opinião e a percepção de produtores e técnicos sobre alguns temas relacionados à administração da empresa agropecuária no Brasil.

* Nenhuma informação individual será divulgada.

Indique apenas a sua atividade principal:

․ Agricultor

口 Pecuarista

- Assistência Técnica para a agricultura

口 Assistência Técnica para a pecuária

Outra:

Indique apenas a exploracão principal com a qual trabalha:

口 Produção de grãos (soja, milho, trigo, etc.)

Cana-de-açúcar

- Outras lavouras:

口 Bovinocultura de corte

Bovinocultura de leite

․ Outras criações:

\section{Indique a sua idade:}

Até 30 anos

$\quad$ De 31 a 40 anos

$\quad$ De 41 a 50 anos

Mais de 50 anos 
Indique seu grau de escolaridade:

口 Até o primeiro grau (completo)

- Segundo grau (completo ou incompleto)

口 Superior (completo ou incompleto)

Indique o principal município onde trabalha:

\section{INSTRUCÕES PARA RESPONDER AS QUESTÕES SEGUINTES:}

Responda se você concorda ou não com as afirmações abaixo.

Para isso, atribua notas de $\mathbf{0}$ a 10, de acordo com sua menor ou maior concordância com as afirmações, considerando que:

$\checkmark \quad$ nota 0 significa que você discorda integralmente da afirmação;

$\checkmark \quad$ notas intermediárias (de 1 a 4) significam discordância parcial;

$\checkmark \quad$ nota 5 significa indiferença;

$\checkmark \quad$ notas intermediárias (de 6 a 9) significam concordância parcial;

$\checkmark \quad$ nota 10 significa que você concorda integralmente com a afirmação;

\begin{tabular}{|c|c|c|c|c|c|c|c|c|c|c|}
\hline \multicolumn{2}{|l|}{ Maior discordância } & \multicolumn{4}{c|}{$\longrightarrow$} \\
\hline 0 & 1 & 2 & 3 & 4 & 5 & 6 & 7 & 8 & 9 & 10 \\
\hline
\end{tabular}

1-) "Na última década, os gastos para a manutenção da família têm crescido a uma velocidade maior do que o aumento de receita líquida da propriedade rural”.

Nota:

2-) "Promover um bom padrão de vida para a família é o principal objetivo da propriedade rural".

Nota: 
3-) "O resultado econômico/financeiro das atividades agropecuárias é afetado, muito mais por variações do clima e dos preços agrícolas, do que por problemas administrativos internos da propriedade rural".

Nota:

4-) "No atendimento ao produtor, a assistência técnica concentra seu trabalho na orientação da produção e atua pouco em questões administrativas das propriedades rurais".

Nota:

5-) A necessidade de usar a infraestrutura existente na propriedade e a incerteza quanto aos preços futuros (que podem ser altos ou baixos) estimula o produtor rural a manter sua produção, de acordo com o seu planejamento de longo prazo.

Nota:

6-) "É preferível fazer o planejamento da propriedade mentalmente e não por escrito, pois são constantes as mudanças na política econômica, no clima e nos preços. $\mathrm{O}$ planejamento mental é mais versátil do que o planejamento escrito".

Nota:

7-) "Se o produtor rural começar a fazer muitas contas no papel e verificar os prováveis resultados, ele poderia perder o estímulo de produzir".

Nota:

8-) "A necessidade de caixa (dinheiro) para pagar compromissos financeiros, normalmente é o que determina o momento da venda da produção“.

Nota: 
9-) "Os produtores rurais preferem trabalhar as suas atividades com maior estoque patrimonial (terras, máquinas, animais) do que com maior liquidez no caixa (disponibilidade financeira). Por isso, em anos de sobra de caixa, preferem investir na propriedade do que guardar o dinheiro no banco".

Nota:

10-) A principal dificuldade para se planejar a compra de insumos é a falta de recursos financeiros na propriedade em determinadas épocas do ano.

Nota:

11-) “A legislação trabalhista é mais adaptada ao meio urbano. Por isso, em propriedades rurais, é mais difícil cumpri-la integralmente”.

Nota:

12-) "As propriedades rurais normalmente trabalham com ociosidade de mão-de-obra fixa, pois na média anual, o número de empregados fixos é determinado em função dos períodos de maior necessidade de trabalho".

Nota:

13-) "O produtor rural tem uma maior preocupação com os aspectos de produção (tecnologia) do que pelos aspectos administrativos de sua propriedade".

Nota:

14-) “As propriedades rurais normalmente trabalham com infraestrutura ociosa (máquinas, equipamentos, etc.), pois na média anual, o tamanho dessa infraestrutura é determinado em função da possibilidade de ocorrer períodos críticos (adversidades climáticas, etc)".

Nota: 
15-) "Na avaliação da propriedade, o mais importante é conhecer os resultados globais, pois as diferenças de resultados entre talhões/lotes geralmente se devem a questões climáticas ou a outras variáveis que não podem ser controladas pelo produtor”.

Nota:

16-) "O produtor rural tem dificuldade para entender e utilizar os softwares (programas de computador) desenvolvidos para o meio rural".

Nota:

17-) "O produtor rural recebe constantemente informações de muitas pessoas e instituições e de várias formas (até via TV). Isso dificulta a escolha do melhor produto (insumo) comercial a ser utilizado na propriedade".

Nota:

18-) "Há uma grande pressão das empresas e/ou cooperativas sobre o produtor rural para que ele seja fiel na entrega de sua produção"

Nota:

19-) “O produtor rural não tem tempo para fazer planejamento por escrito e manter controles pormenorizados. É uma correria todo dia, para executar os serviços e tarefas operacionais que exigem atenção permanente".

Nota:

20-) "Como o produtor tem que gastar a maior parte do seu tempo cuidando da produção, sobra a ele pouco tempo para analisar as áreas financeira e comercial da empresa rural".

Nota:

21-) "Os bons produtores rurais são aqueles que obtém alta produtividade".

Nota: 
22-) "Primeiro é preciso melhorar a tecnologia para aumentar a produtividade, depois se preocupar com planos e controles para a propriedade.

Nota:

23-) "A grande maioria dos produtores rurais não separa em seus registros os gastos da família e os gastos da propriedade".

Nota:

24-) "Alguns dados financeiros da propriedade (como o valor dos gastos familiares, o valor de dívidas, etc.) não são assunto para serem tratados com profissionais da assistência técnica.

Nota:

25-) "O envolvimento dos profissionais da assistência técnica com a venda de insumos inibe os produtores rurais, de receber deles, assessoria administrativa na propriedade".

Nota:

26-) "Comprar e vender é tarefa do produtor rural. Raramente (à exceção das transações de pequenos valores) ela é delegada a funcionários da fazenda”.

Nota:

27-) "No meio agropecuário não adianta muito querer controlar tudo por escrito. $\mathrm{O}$ importante é o responsável estar presente na propriedade, pois assim já estaria efetuando os controles de forma visual, mas permanente".

Nota: 
28-) "No meio agropecuário, as ordens de serviço que os produtores repassam aos funcionários devem ser bem claras e diretas, pois não adianta muito ficar trocando idéias com os funcionários".

Nota:

29-) "Se o profissional da assistência técnica prestar ao produtor uma boa orientação tecnológica, isso já é uma grande contribuição para a propriedade, pois questões administrativas são responsabilidade do produtor rural".

Nota:

30-) "As propriedades rurais, geralmente não adotam sistemas detalhados de controle de custos pela grande dificuldade de se coletar dados precisos (ou exatos) em nível de campo".

Nota:

31-) "Alguns poucos indicadores de eficiência (produtividade, índices zootécnicos, etc.) e de resultado (sobra de dinheiro em caixa, etc.) são suficientes para indicar se a propriedade está indo bem ou mal".

Nota:

32-) "As propriedades rurais, geralmente não adotam sistemas detalhados de controle porque esse trabalho não garante um aumento na rentabilidade”.

Nota:

33-) "É possível que um sistema de controle simplificado seja suficiente para garantir uma boa administração da propriedade rural, porque eles permitem, pelo menos, uma noção sobre os resultados técnicos e econômicos do empreendimento".

Nota: 
34-) "Na compra dos insumos e na venda da produção, o mais importante é controlar as quantidades para evitar desvios, pois os preços são definidos pelo mercado".

Nota:

35-) "Os funcionários das propriedades rurais não gostam de fazer anotações por escrito sobre as tarefas realizadas".

Nota:

36-) "Os funcionários das propriedades rurais não sabem ou têm muitas dificuldades para fazer anotações por escrito sobre as tarefas realizadas".

Nota: 


\section{APÊNDICE 3: Resultados estatísticos}

Tabela 26: Média aritmética, desvio padrão, mediana e valor do teste $\mathrm{G}^{2}$ das respostas às questões formuladas, para o total da amostra.

\begin{tabular}{|c|c|c|c|c|}
\hline Questões & média aritmética & desvio padrão & mediana & Teste $\mathrm{G}^{2}$ \\
\hline 1 & 8,65 & 1,86 & 9 & 0,1259 \\
\hline 2 & 7,78 & 2,43 & 8 & 0,0253 \\
\hline 3 & 6,57 & 2,82 & 7 & $<0,0001$ \\
\hline 4 & 7,58 & 2,32 & 8 & 0,0181 \\
\hline 5 & 6,34 & 2,56 & 7 & 0,0468 \\
\hline 6 & 2,52 & 3,08 & 1 & 0,0101 \\
\hline 7 & 5,11 & 3,59 & 5 & 0,1921 \\
\hline 8 & 7,75 & 2,58 & 8 & 0,0880 \\
\hline 9 & 7,88 & 2,09 & 8 & 0,2217 \\
\hline 10 & 7,61 & 2,50 & 8 & 0,0007 \\
\hline 11 & 7,48 & 2,72 & 8 & 0,3582 \\
\hline 12 & 6,54 & 2,93 & 7 & 0,1798 \\
\hline 13 & 7,40 & 2,18 & 8 & 0,0009 \\
\hline 14 & 6,79 & 2,51 & 7 & 0,0130 \\
\hline 15 & 5,06 & 3,25 & 5 & 0,0029 \\
\hline 16 & 7,97 & 2,36 & 9 & 0,0896 \\
\hline 17 & 5,32 & 3,20 & 5 & 0,6800 \\
\hline 18 & 7,65 & 2,62 & 8 & 0,0006 \\
\hline 19 & 4,65 & 3,32 & 4 & 0,0020 \\
\hline 20 & 4,88 & 3,24 & 5 & 0,0036 \\
\hline 21 & 6,21 & 3,05 & 7 & 0,0061 \\
\hline 22 & 4,53 & 3,23 & 4 & 0,0142 \\
\hline 23 & 8,02 & 2,46 & 9 & 0,0135 \\
\hline 24 & 4,72 & 3,51 & 4 & 0,0009 \\
\hline 25 & 5,85 & 3,02 & 6 & 0,0053 \\
\hline 26 & 7,91 & 2,66 & 9 & 0,0107 \\
\hline 27 & 4,17 & 3,40 & 4 & $<0,0001$ \\
\hline 28 & 4,42 & 3,11 & 4 & 0,0008 \\
\hline 29 & 6,08 & 3,20 & 7 & $<0,0001$ \\
\hline 30 & 6,39 & 2,92 & 7 & 0,1939 \\
\hline 31 & 5,33 & 3,00 & 6 & 0,1084 \\
\hline 32 & 3,71 & 2,96 & 3 & 0,0040 \\
\hline 33 & 7,41 & 2,32 & 8 & 0,6128 \\
\hline 34 & 5,85 & 3,21 & 6 & 0,0041 \\
\hline 35 & 7,88 & 2,30 & 8 & 0,4359 \\
\hline 36 & 7,48 & 2,44 & 8 & 0,1004 \\
\hline
\end{tabular}


Tabela 27. Distribuição percentual de frequiência das respostas às questões formuladas, para o total da amostra.

\begin{tabular}{|c|c|c|c|c|c|c|c|c|c|c|c|}
\hline \multirow{2}{*}{ Questões } & \multicolumn{11}{|c|}{ Notas } \\
\hline & 0 & 1 & 2 & 3 & 4 & 5 & 6 & 7 & 8 & 9 & 10 \\
\hline 1 & 0,6 & 0,4 & 0,8 & 1,0 & 0,2 & 3,7 & 4,5 & 8,4 & 17,8 & 12,9 & 49,7 \\
\hline 2 & 2,2 & 0,6 & 2,9 & 1,6 & 1,6 & 5,5 & 9,4 & 12,4 & 19,0 & 9,6 & 35,1 \\
\hline 3 & 3,7 & 1,0 & 4,7 & 8,1 & 7,9 & 8,8 & 9,8 & 10,0 & 15,9 & 10,8 & 19,3 \\
\hline 4 & 2,0 & 0,4 & 1,0 & 4,5 & 2,6 & 6,9 & 7,5 & 11,6 & 22,6 & 17,3 & 23,4 \\
\hline 5 & 3,1 & 1,4 & 4,7 & 6,2 & 6,0 & 14,4 & 10,5 & 15,0 & 19,1 & 8,0 & 11,5 \\
\hline 6 & 42,4 & 10,0 & 9,2 & 8,2 & 7,1 & 5,3 & 4,5 & 2,2 & 3,3 & 2,2 & 5,5 \\
\hline 7 & 17,8 & 3,7 & 9,4 & 6,5 & 6,7 & 9,6 & 6,5 & 5,9 & 9,0 & 7,3 & 17,6 \\
\hline 8 & 3,9 & 1,2 & 1,2 & 2,6 & 2,2 & 4,7 & 5,9 & 9,9 & 20,7 & 16,2 & 31,4 \\
\hline 9 & 0,6 & 0,6 & 0,8 & 2,0 & 3,3 & 7,7 & 7,5 & 8,7 & 23,6 & 18,1 & 27,0 \\
\hline 10 & 1,8 & 0,8 & 2,9 & 3,9 & 3,9 & 5,3 & 7,3 & 9,8 & 20,8 & 13,8 & 29,7 \\
\hline 11 & 3,9 & 0,8 & 2,6 & 2,8 & 3,4 & 8,9 & 6,1 & 9,5 & 16,8 & 13,0 & 32,0 \\
\hline 12 & 5,3 & 2,1 & 5,1 & 5,3 & 6,3 & 9,1 & 7,4 & 12,7 & 18,1 & 9,3 & 19,4 \\
\hline 13 & 1,8 & 0,6 & 1,0 & 1,8 & 4,3 & 8,7 & 10,0 & 12,8 & 26,0 & 16,1 & 16,9 \\
\hline 14 & 2,2 & 2,0 & 2,0 & 4,5 & 6,7 & 11,6 & 11,6 & 10,8 & 21,8 & 11,0 & 15,5 \\
\hline 15 & 12,1 & 4,7 & 9,5 & 9,5 & 9,9 & 9,7 & 6,1 & 8,9 & 10,9 & 7,3 & 11,3 \\
\hline 16 & 1,6 & 0,6 & 2,0 & 2,2 & 3,7 & 6,1 & 4,9 & 6,5 & 19,5 & 19,1 & 33,7 \\
\hline 17 & 11,6 & 3,9 & 8,1 & 7,9 & 7,3 & 12,0 & 7,9 & 9,1 & 13,2 & 8,1 & 11,0 \\
\hline 18 & 3,0 & 1,2 & 3,2 & 1,6 & 3,0 & 7,7 & 4,5 & 8,9 & 19,7 & 15,6 & 31,4 \\
\hline 19 & 15,8 & 5,9 & 8,5 & 12,6 & 8,1 & 10,3 & 6,9 & 5,7 & 8,5 & 7,1 & 10,7 \\
\hline 20 & 12,4 & 7,5 & 8,7 & 10,8 & 7,7 & 7,5 & 7,5 & 11,6 & 10,8 & 5,5 & 10,1 \\
\hline 21 & 7,1 & 2,2 & 5,9 & 4,9 & 5,5 & 14,0 & 9,8 & 9,8 & 14,4 & 6,3 & 20,1 \\
\hline 22 & 15,2 & 7,5 & 8,7 & 10,8 & 9,3 & 10,1 & 7,5 & 7,7 & 9,3 & 3,7 & 10,1 \\
\hline 23 & 2,8 & 0,6 & 2,4 & 1,2 & 2,0 & 6,9 & 2,4 & 7,5 & 19,8 & 18,0 & 36,2 \\
\hline 24 & 18,0 & 5,6 & 10,5 & 7,9 & 8,4 & 9,0 & 4,6 & 6,9 & 8,6 & 6,9 & 13,6 \\
\hline 25 & 8,8 & 2,7 & 4,9 & 6,3 & 6,1 & 15,9 & 8,2 & 10,8 & 16,1 & 6,1 & 14,1 \\
\hline 26 & 4,1 & 1,8 & 2,0 & 1,2 & 1,0 & 6,3 & 3,7 & 5,5 & 18,7 & 20,9 & 34,8 \\
\hline 27 & 22,5 & 6,1 & 9,4 & 9,4 & 9,8 & 6,1 & 9,0 & 6,1 & 6,7 & 3,9 & 10,8 \\
\hline 28 & 17,9 & 3,5 & 9,1 & 10,6 & 11,2 & 9,3 & 8,9 & 8,7 & 10,4 & 4,1 & 6,3 \\
\hline 29 & 7,3 & 2,8 & 7,3 & 8,7 & 6,5 & 8,1 & 8,3 & 6,7 & 15,0 & 10,2 & 18,9 \\
\hline 30 & 5,5 & 2,4 & 5,3 & 5,5 & 7,9 & 7,1 & 9,7 & 12,8 & 16,0 & 12,0 & 15,8 \\
\hline 31 & 10,0 & 2,9 & 6,7 & 9,6 & 10,6 & 9,6 & 10,4 & 10,6 & 15,1 & 5,5 & 9,2 \\
\hline 32 & 20,1 & 7,6 & 11,3 & 14,2 & 9,4 & 10,1 & 6,6 & 6,6 & 7,2 & 2,5 & 4,5 \\
\hline 33 & 1,2 & 0,8 & 2,8 & 2,6 & 4,9 & 5,9 & 10,2 & 13,4 & 22,0 & 14,4 & 21,7 \\
\hline 34 & 9,8 & 2,4 & 6,7 & 6,3 & 8,1 & 11,0 & 7,3 & 9,6 & 12,6 & 9,8 & 16,3 \\
\hline 35 & 1,2 & 0,4 & 2,6 & 2,4 & 3,2 & 6,5 & 4,1 & 8,9 & 23,9 & 15,6 & 31,0 \\
\hline 36 & 2,3 & 0,8 & 2,5 & 2.5 & 3.8 & 8,4 & 6.5 & 10,7 & 21,3 & 18,8 & 22,4 \\
\hline
\end{tabular}


Tabela 28. Mediana das respostas às questões formuladas, segundo a atividade principal do entrevistado e o total da amostra.

\begin{tabular}{|c|c|c|c|c|c|c|}
\hline Questões & Agricultor & Pecuarista & $\begin{array}{l}\text { Técnicos } \mathrm{p} / \\
\text { agricultura }\end{array}$ & $\begin{array}{l}\text { Técnicos p/ } \\
\text { pecuária }\end{array}$ & $\begin{array}{c}\text { Outros } \\
\text { profissionais }\end{array}$ & $\begin{array}{l}\text { Total da } \\
\text { amostra }\end{array}$ \\
\hline 1 & 10 & 10 & 9 & 9 & 9 & 9 \\
\hline 2 & 8 & 10 & 8 & 7 & 8 & 8 \\
\hline 3 & 8 & 7 & 6 & 3 & 6,5 & 7 \\
\hline 4 & 8 & 8 & 8 & 7 & 8 & 8 \\
\hline 5 & 7 & 7 & 7 & 6 & 7 & 7 \\
\hline 6 & 2 & 2,5 & 0 & 0 & 1 & 1 \\
\hline 7 & 6 & 5 & 4 & 3 & 5 & 5 \\
\hline 8 & 9 & 9 & 9 & 8 & 8 & 8 \\
\hline 9 & 8 & 9 & 8 & 8 & 8 & 8 \\
\hline 10 & 8 & 9 & 8 & 7 & 8 & 8 \\
\hline 11 & 9 & 9 & 8 & 8 & 8 & 8 \\
\hline 12 & 8 & 7 & 7 & 7 & 7 & 7 \\
\hline 13 & 8 & 8 & 9 & 8 & 8 & 8 \\
\hline 14 & 7 & 8 & 7 & 7 & 7 & 7 \\
\hline 15 & 5 & 6 & 3 & 3 & 5 & 5 \\
\hline 16 & 8 & 9 & 9 & 9 & 8 & 9 \\
\hline 17 & 5 & 7 & 6 & 7 & 5 & 5 \\
\hline 18 & 8 & 9 & 9 & 7 & 8 & 8 \\
\hline 19 & 5 & 6 & 2,5 & 2 & 4 & 4 \\
\hline 20 & 5 & 7 & 3 & 3 & 5 & 5 \\
\hline 21 & 7 & 8 & 5 & 5 & 7 & 7 \\
\hline 22 & 5 & 6 & 3 & 2 & 4 & 4 \\
\hline 23 & 8 & 9 & 9 & 9 & 8 & 9 \\
\hline 24 & 6 & 5 & 2 & 2 & 4 & 4 \\
\hline 25 & 6 & 7 & 5 & 7 & 6 & 6 \\
\hline 26 & 9 & 9 & 9 & 8 & 8 & 9 \\
\hline 27 & 5 & 5 & 2 & 0 & 3 & 4 \\
\hline 28 & 5 & 6 & 2 & 2 & 4 & 4 \\
\hline 29 & 8 & 8 & 3 & 4 & 6 & 7 \\
\hline 30 & 7 & 8 & 7 & 5 & 7 & 7 \\
\hline 31 & 6 & 5,5 & 4 & 5 & 6 & 6 \\
\hline 32 & 4 & 4 & 2 & 2 & 3 & 3 \\
\hline 33 & 8 & 8 & 8 & 8 & 8 & 8 \\
\hline 34 & 6 & 7 & 4 & 5 & 7 & 6 \\
\hline 35 & 8 & 9 & 9 & 9 & 8 & 8 \\
\hline 36 & 8 & 8 & 8 & 8 & 8 & 8 \\
\hline
\end{tabular}


Tabela 29. Distribuição percentual de freqüência das notas atribuídas às questões, em intervalos de notas de 0 a 3, 4 a 6, e 7 a 10, segundo a atividade principal do entrevistado.

\begin{tabular}{|c|c|c|c|c|c|c|c|c|c|c|c|c|c|c|c|c|c|c|}
\hline \multirow[b]{2}{*}{$\begin{array}{l}\text { Ques- } \\
\text { tões }\end{array}$} & \multicolumn{3}{|c|}{ Agricultor } & \multicolumn{3}{|c|}{ Pecuarista } & \multicolumn{3}{|c|}{ Téc. p/ agric } & \multicolumn{3}{|c|}{ Téc. p/ pec. } & \multicolumn{3}{|c|}{ Outros } & \multicolumn{3}{|c|}{ Total } \\
\hline & $\begin{array}{c}0 \mathrm{a} \\
3\end{array}$ & $\begin{array}{c}4 \mathrm{a} \\
6\end{array}$ & $\begin{array}{l}7 \mathrm{a} \\
10\end{array}$ & $\begin{array}{c}0 \mathrm{a} \\
3\end{array}$ & $\begin{array}{c}4 \mathrm{a} \\
6\end{array}$ & $\begin{array}{l}7 \mathrm{a} \\
10\end{array}$ & $\begin{array}{c}0 \mathrm{a} \\
3\end{array}$ & $\begin{array}{c}4 \mathrm{a} \\
6\end{array}$ & $\begin{array}{l}7 \mathrm{a} \\
10\end{array}$ & $\begin{array}{c}0 \mathrm{a} \\
3\end{array}$ & $\begin{array}{c}4 \mathrm{a} \\
6\end{array}$ & $\begin{array}{l}7 \mathrm{a} \\
10\end{array}$ & $\begin{array}{c}0 \mathrm{a} \\
3\end{array}$ & $\begin{array}{c}4 \mathrm{a} \\
6\end{array}$ & $\begin{array}{l}7 \mathrm{a} \\
10\end{array}$ & $\begin{array}{c}0 \mathrm{a} \\
3\end{array}$ & $\begin{array}{c}4 \mathrm{a} \\
6\end{array}$ & $\begin{array}{c}7 \mathrm{a} \\
10\end{array}$ \\
\hline 1 & 4 & 9 & 87 & 1 & 6 & 93 & 2 & 6 & 93 & 3 & 13 & 85 & 3 & 0 & 88 & 3 & 8 & 89 \\
\hline 2 & 6 & 14 & 79 & 6 & 13 & 80 & 8 & 17 & 75 & $\overline{13}$ & 23 & 64 & 8 & 18 & 72 & 7 & 17 & 76 \\
\hline 3 & 9 & 17 & 74 & 14 & 27 & 59 & 22 & 30 & 48 & 56 & 31 & 13 & 16 & 34 & 50 & 18 & 26 & 56 \\
\hline 4 & 8 & 23 & 70 & 6 & 16 & 78 & 13 & 9 & 78 & 5 & 32 & 63 & 8 & 11 & 80 & 8 & 17 & 75 \\
\hline 5 & 14 & 30 & 56 & 11 & 28 & 60 & 22 & 20 & 57 & 23 & 44 & 33 & 15 & 33 & 52 & 15 & 31 & 54 \\
\hline 6 & 64 & 21 & 15 & 54 & 24 & 22 & 78 & 15 & 7 & 92 & 3 & 5 & 76 & 13 & 11 & 70 & 17 & 13 \\
\hline 7 & 31 & 23 & 46 & 32 & 26 & 43 & 48 & 24 & 28 & 51 & 28 & 21 & 39 & 20 & 41 & 37 & 23 & 40 \\
\hline 8 & 8 & 13 & 78 & 4 & 15 & 82 & 7 & 15 & 78 & 18 & 15 & 67 & 11 & 10 & 79 & 9 & 13 & 78 \\
\hline 9 & 2 & 21 & 77 & 4 & 16 & 80 & 9 & 17 & 74 & 5 & 28 & 67 & 4 & 16 & 80 & & 18 & 77 \\
\hline 10 & 5 & 18 & 77 & 6 & 15 & 79 & 13 & 13 & 74 & 26 & 18 & 56 & 10 & 16 & 72 & 9 & 16 & 74 \\
\hline 11 & 12 & 15 & 73 & 11 & 16 & 73 & 13 & 19 & 69 & 10 & 21 & 69 & 7 & 23 & 71 & 10 & 18 & 71 \\
\hline 12 & 12 & 24 & 65 & 19 & 29 & 52 & 22 & 13 & 65 & 13 & 31 & 56 & 23 & 21 & 57 & 18 & 23 & 59 \\
\hline 13 & 8 & 29 & 64 & 6 & 31 & 63 & 6 & 4 & 91 & 5 & 21 & 74 & & 20 & 77 & & 23 & 72 \\
\hline 12 & 12 & 31 & 56 & 7 & 29 & 63 & 13 & 28 & 59 & 13 & 26 & 62 & 10 & 31 & 59 & 11 & 30 & 59 \\
\hline 15 & 33 & 26 & 41 & 20 & 32 & 49 & 59 & 19 & 22 & 51 & 21 & 28 & 36 & 26 & 39 & 36 & 26 & 38 \\
\hline 16 & 8 & 17 & 75 & 9 & 13 & 78 & 2 & 6 & 93 & 8 & & 85 & & $\overline{18}$ & 77 & 7 & 15 & 79 \\
\hline 17 & 33 & 31 & 36 & 25 & 25 & 51 & 33 & 20 & 46 & 26 & 18 & 56 & 34 & 29 & 36 & 31 & 27 & 41 \\
\hline $1 \varepsilon$ & 1 & 15 & 74 & 5 & 10 & 85 & 4 & & 91 & 15 & 28 & 56 & 1 & 1 & 72 & & 15 & 76 \\
\hline 19 & 37 & 31 & 32 & 26 & 27 & 48 & 57 & 24 & 19 & 72 & $\bar{\varepsilon}$ & 21 & 45 & 24 & 31 & 43 & 25 & 32 \\
\hline 20 & 33 & 27 & 40 & 27 & 17 & 56 & 51 & 23 & 26 & 62 & 13 & 26 & 43 & 2 & 34 & 9 & 23 & 38 \\
\hline 2 & 20 & 22 & 58 & 15 & 27 & 58 & 32 & 38 & 30 & 23 & 49 & 28 & 18 & 3 & 52 & 20 & 29 & 51 \\
\hline 22 & 35 & 31 & 34 & 30 & 21 & 49 & 56 & 28 & 17 & 69 & 15 & 15 & 44 & 29 & 28 & 42 & 27 & 31 \\
\hline 23 & 11 & 14 & 75 & 4 & 17 & 79 & 7 & 7 & 85 & 5 & & 92 & & & 86 & 7 & 11 & 82 \\
\hline 24 & 32 & 23 & 45 & 35 & 20 & 45 & 56 & 17 & 28 & 67 & 10 & 23 & 44 & 27 & 29 & 42 & 22 & 36 \\
\hline 25 & 24 & 31 & 45 & 23 & 23 & 55 & 28 & 28 & 44 & 23 & 23 & 54 & 19 & 36 & 45 & 23 & 30 & 47 \\
\hline 26 & 11 & 10 & 79 & 7 & 9 & 84 & 2 & 11 & 87 & 15 & 13 & $\overline{72}$ & 9 & 13 & 78 & 9 & 11 & 80 \\
\hline 27 & 37 & 27 & 36 & 32 & 29 & 39 & 67 & 26 & 7 & 79 & 5 & 15 & 52 & 25 & 23 & 47 & 25 & 28 \\
\hline 28 & 32 & 31 & 37 & 33 & 28 & 38 & 59 & 20 & 20 & 64 & 23 & 13 & 42 & 33 & 25 & 41 & 29 & 29 \\
\hline 29 & 17 & 23 & 59 & 9 & 22 & 70 & 59 & 20 & 20 & 46 & 23 & 31 & 28 & 24 & 48 & 26 & 23 & 51 \\
\hline 30 & 15 & 24 & 61 & 11 & 26 & 63 & 26 & 22 & 52 & 36 & 23 & 41 & 19 & 26 & 54 & 19 & 25 & 57 \\
\hline 31 & 26 & 30 & 44 & 23 & 35 & 43 & 43 & 30 & 28 & 31 & 41 & 28 & 30 & 27 & 43 & 29 & 31 & 40 \\
\hline 32 & 46 & 26 & 28 & 46 & 34 & 20 & 69 & 19 & 12 & 74 & 8 & 18 & 53 & 29 & 18 & 53 & 26 & 21 \\
\hline 33 & 9 & 17 & 74 & 4 & 22 & 74 & 7 & 26 & 67 & 5 & 23 & 72 & 9 & 22 & 69 & 8 & 21 & 72 \\
\hline 34 & 25 & 26 & 49 & 20 & 20 & 60 & 39 & 33 & 28 & 23 & 44 & 33 & 25 & 23 & 52 & 25 & 26 & 48 \\
\hline 35 & 6 & 19 & 75 & 11 & 5 & 84 & 6 & 7 & 87 & 8 & 10 & 82 & 5 & 16 & 79 & 7 & 14 & 80 \\
\hline 36 & 12 & 19 & 69 & 7 & 16 & 77 & 11 & 15 & 74 & 5 & 13 & 82 & 5 & 22 & 73 & 8 & 19 & 73 \\
\hline
\end{tabular}

